UNIVERSIDADE DE SÃO PAULO

FACULDADE DE FILOSOFIA, LETRAS E CIÊNCIAS HUMANAS DEPARTAMENTO DE LETRAS CLÁSSICAS E VERNÁCULAS PROGRAMA DE PÓS-GRADUAÇÃO EM LITERATURA BRASILEIRA

MOLDAR O INEXPRESSIVO:

A FORMAÇÃO DO ARTISTA EM CLARICE LISPECTOR E A ESCRITA ESCULTÓRICA EM A PAIXÃO SEGUNDO G.H.

MARIANA SILVA BIJOTTI

Versão Corrigida

São Paulo

2020 
UNIVERSIDADE DE SÃO PAULO

FACULDADE DE FILOSOFIA, LETRAS E CIÊNCIAS HUMANAS

DEPARTAMENTO DE LETRAS CLÁSSICAS E VERNÁCULAS

PROGRAMA DE PÓS-GRADUAÇÃO EM LITERATURA BRASILEIRA

\section{MOLDAR O INEXPRESSIVO: \\ A FORMAÇÃO DO ARTISTA EM CLARICE LISPECTOR E A ESCRITA ESCULTÓRICA EM A PAIXÃO SEGUNDO G.H.}

MARIANA SILVA BIJOTTI

Dissertação apresentada ao Programa de Pós-Graduação em

Literatura Brasileira da Faculdade de Filosofia, Letras e Ciências Humanas da Universidade de São Paulo para a obtenção do título de Mestre em Literatura Brasileira.

Orientadora: Profa. Dra. Simone Rossinetti Rufinoni

Versão Corrigida

São Paulo

2020 
Autorizo a reprodução e divulgação total ou parcial deste trabalho, por qualquer meio convencional ou eletrônico, para fins de estudo e pesquisa, desde que citada a fonte.

Catalogação na Publicação

Serviço de Biblioteca e Documentação

Faculdade de Filosofia, Letras e Ciências Humanas da Universidade de São Paulo

BB576m

Bijotti, Mariana Silva

Moldar o inexpressivo: a formação do artista em

Clarice Lispector e a escrita escultórica em A paixão segundo G.H. / Mariana Silva Bijotti ; orientadora Simone Rossinetti Rufinoni. - São Paulo, 2020.

$161 \mathrm{f}$.

Dissertação (Mestrado)- Faculdade de Filosofia, Letras e Ciências Humanas da Universidade de São Paulo. Departamento de Letras Clássicas e Vernáculas. Área de concentração: Literatura Brasileira.

1. Literatura brasileira. 2. Clarice Lispector. 3. A paixão segundo G.H. . 4. Escultura. 5. Artista. I. Rufinoni, Simone Rossinetti, orient. II. Título. 


\section{ENTREGA DO EXEMPLAR CORRIGIDO DA DISSERTAÇÃO/TESE \\ Termo de Ciência e Concordância do (a) orientador (a)}

Nome do (a) aluno (a): Mariana Silva Bijotti

Data da defesa: 02/10/2020

Nome do Prof. (a) orientador (a): Simone Rossinetti Rufinoni

Nos termos da legislação vigente, declaro ESTAR CIENTE do conteúdo deste EXEMPLAR CORRIGIDO elaborado em atenção às sugestões dos membros da comissão Julgadora na sessão de defesa do trabalho, manifestando-me plenamente favorável ao seu encaminhamento e publicação no Portal Digital de Teses da USP.

São Paulo, 15/10/2020

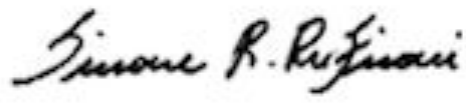

(Assinatura do (a) orientador (a) 
BIJOTTI, Mariana Silva. Moldar o inexpressivo: a formação do artista em Clarice Lispector e a escrita escultórica em A paixão segundo G.H.. Dissertação apresentada ao Programa de Pós-Graduação em Literatura Brasileira da Universidade de São Paulo para a obtenção do título de Mestre em Literatura Brasileira.

Aprovada em:

Orientadora: Profa. Dra. Simone Rossinetti Rufinoni

Banca Examinadora:

Examinador(a): Instituição:

Julgamento:

Assinatura:

Examinador(a):

Instituição:

Julgamento:

Assinatura:

Examinador(a): Instituição:

Julgamento:

Assinatura: 
"Eu sou um artista”... esta frase subentende o significado de "sempre procurar sem jamais encontrar a perfeição". É exatamente o contrário de "eu já sei, eu já encontrei". Esta frase significa, pelo quanto eu saiba, "eu procuro, eu persigo, eu o faço com toda dedicação”. 


\section{AGRADECIMENTOS}

À minha orientadora, Profa. Dra. Simone Rossinetti Rufinoni, por aceitar me guiar nessa jornada, que traçamos desde a graduação, e por todas as conversas sobre a complexidade e as belezas de Clarice, que muito inspiraram este estudo.

Ao Conselho Nacional de Desenvolvimento Científico e Tecnológico (CNPq), pela bolsa de mestrado concedida de março de 2018 a março de 2020, tornando possível toda a dedicação necessária a essa pesquisa ${ }^{1}$.

À Coordenação de Aperfeiçoamento de Pessoal de Nível Superior (CAPES) pelo apoio dado ao Programa de Pós-Graduação em Literatura Brasileira.

Ao Programa de Pós-Graduação em Literatura Brasileira da USP e ao Departamento de Letras Clássicas e Vernáculas, também por todo apoio dado durante esses anos, permitindo-me (literalmente) voar para outros continentes com minha pesquisa.

À banca de qualificação deste mestrado, Profa. Dra. Yudith Rosenbaum - obrigada pelas aulas incríveis de Clarice desde a graduação, pela leitura cuidadosa do meu relatório de qualificação e pela ótima companhia nos eventos clariceanos - e Prof. Dr. Gilberto Figueiredo Martins - obrigada pelos apontamentos extremamente significativos que tanto me auxiliaram após esse encontro. E à banca de defesa, Profa. Dra. Veronica Stigger - cujo curso maravilhoso sobre Clarice ampliou meu olhar sobre a autora para um outro horizonte que me era até então desconhecido -, Profa. Dra. Yudith Rosenbaum e Prof. Dr. Gilberto Figueiredo Martins. A leitura atenta que os três fizeram da minha dissertação gerou um debate muito enriquecedor, que me propiciou ainda mais reflexões acerca do tema que pretendi estudar.

Aos meus pais, Marcia e Luiz, e às minhas irmãs, Isabela e Catarina, por todo apoio e amor incondicionais. São tantas coisas a agradecer! Minha caminhada nessa vida fica muito melhor com vocês!

Ao Gustavo, por toda paciência, toda ajuda, todo amor e todo carinho de sempre. Também são muitas coisas a agradecer a você. Ter você do meu lado faz com que tudo isso seja ainda mais bonito!

À Beatriz e à Aryanna, pela amizade valiosa, pelos momentos de café na letras e pela companhia mais do que especial na minha banca de qualificação e de defesa. E à Vitória, à Jessica e à Flavia, pela força nesse momento da defesa e, claro, também pela amizade carinhosa ao longo desses tantos anos.

A todos aqueles não nomeados aqui, mas que estiveram comigo durante essa jornada (ou ao menos em algum momento dela). Sintam-se todos abraçados e agradecidos!

Sinto-me muito feliz e privilegiada por ter encontrado todos vocês. Cada um tem sua contribuição nessa travessia, tornando essa conquista uma alegria inexprimível.

\footnotetext{
${ }^{1}$ Concessão de bolsa número 133604/2018-7.
} 


\section{RESUMO}

Uma das tendências do romance moderno, o romance de introversão, ao explicitar os métodos de sua própria composição na narrativa, tornou evidente a figura daquele que o escreve: o artista. Na obra de Clarice Lispector vários são os protagonistas artistas: Joana, de Perto do coração selvagem, escreve poesias e brinca com as palavras desde sua infância; Virgínia, de O lustre, faz pequenas estátuas de bonecos de barro; em Água viva, a narradora é, também, pintora; Rodrigo S.M., de A hora da estrela, é um escritor; em Um sopro de vida, há um autor não nomeado, que é um escritor, e Ângela Pralini, a qual possui um maior entusiasmo pela pintura; finalmente, a narradora protagonista G.H., que é identificada como um escultora. Além disso, muitos são os textos clariceanos que versam sobre as diversas artes, desde a escrita, passando pela pintura até a escultura: em contos, crônicas e, inclusive, no papel de entrevistadora, Clarice demonstrava profundo interesse em discutir arte, procurando, nas entrevistas com artistas, saber a respeito dos seus métodos de trabalho, bem como de suas opiniões gerais sobre o tema. O foco desta dissertação se dará sobre a escultura, primeiramente investigando escritos diversos em que Clarice trata desse assunto, para culminar, enfim, no cerne desta pesquisa: A paixão segundo G.H.. A escultora G.H. parece, de alguma forma, unir sua arte primeira à arte da palavra, compondo uma espécie de "escrita escultórica" e, ainda, parecendo talhar "esculturas verbais" durante seu relato. Dessa maneira, pretende-se, aqui, percorrer alguns dos textos clariceanos que discutem as diversas artes e a figura do artista, para poder finalmente analisar com maior atenção a obra A paixão segundo G.H., procurando estabelecer relações entre a construção dessa narrativa e o desejo clariceano de "tocar a coisa" com as mãos, tal qual um escultor em sua atividade; demonstrando como a modalidade artística de G.H. parece ser captada pela própria forma do romance.

Palavras-chave: Clarice Lispector; Künstlerroman; escultura; artista; A paixão segundo G.H. 


\begin{abstract}
One of the tendencies of the modern novel, the introverted novel, when turning explicit the methods of its own narrative composition, makes evident the image of that who writes it: the artist. In Clarice Lispector's works, several are the artist protagonists: Joana, from Near to the wild heart, writes poetry and play with words since her childhood; Virgínia, from The chandelier, makes little statues of clay dolls; in Agua viva, the narrator is also a painter; Rodrigo S.M., from The hour of the star, is a writer; in A breath of life, there is a not named author, who is a writer, and Ângela Pralini, who has a greater enthusiasm for painting; finally, the protagonist narrator G.H., who is identified as a sculptor. Besides that, many are the texts from Clarice that discuss about the varied arts, from the writing to the painting and sculpture: in short stories, chronicles and also in the role as interviewer, Clarice showed a deep interest in debate art, searching after the working methods of the interviewed artists as well as their general opinions about this theme. The focus of this dissertation will be the sculpture, firstly investigating miscellaneous writings in which Clarice addresses this issue, to culminate, in the end, in the heartwood of this research: The passion according to G.H..The sculptor G.H. seems somehow to unite her first art to the art of the word, compounding a sort of "sculptural writing" and yet seeming to carve "verbal sculptures" during her story. Thus, what is intended here is to pursue some of Lispector's texts that talks over the varied arts and the image of the artist, in order to finally analyse with greater attention the novel The passion according to G.H., trying to establish relations between the construction of this narrative and Clarice's wish to "touch the thing" with her hands, as a sculptor in his activity; demonstrating how the artistic modality of G.H. seems to be captured by the own form of the novel.
\end{abstract}

Keywords: Clarice Lispector; Künstlerroman; sculpture; artist; The passion according to G.H. 


\section{SUMÁRIO}

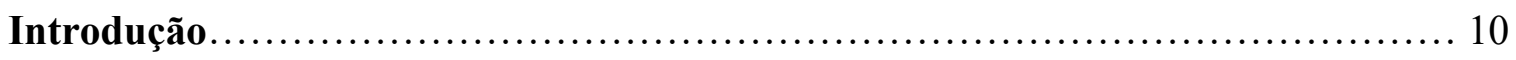

1. $\mathrm{O}$ artista na modernidade .................................................. 14

$1.1 \mathrm{O}$ romance de introversão e o romance de artista ................................ 14

1.2 A condição feminina ......................................................... 19

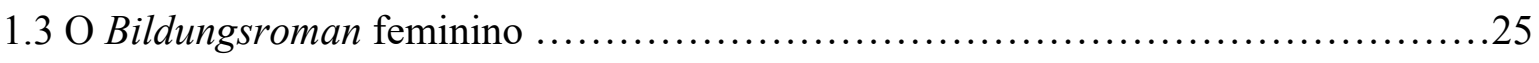

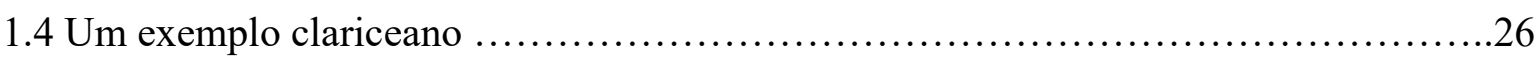

2. Clarice Lispector: entre a escrita e as artes visuais ............................ 32

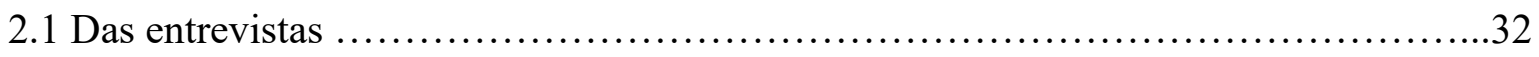

2.2 Das crônicas ......................................................... 42

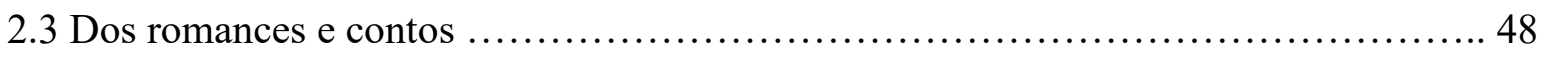

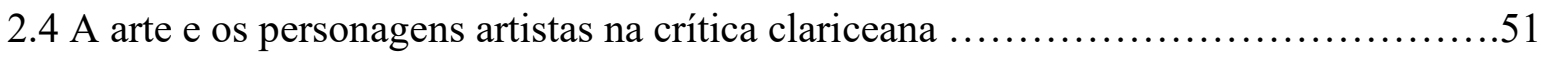

3. A escultura na ficção clariceana: três exemplos comparados $\ldots \ldots \ldots \ldots \ldots \ldots \ldots \ldots . \ldots 5$

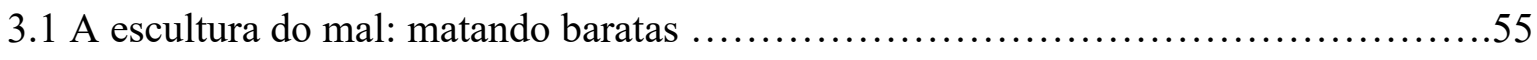

$3.2 \mathrm{O}$ artista em criação: O lustre e A paixão segundo G.H............................. 59

4. A paixão segundo G.H.: a transgressão do artista ............................ 65

4.1 Breve panorama sobre a fortuna crítica de A paixão segundo G.H.: textos essenciais...65

4.2 Desvendando G.H.: a mulher e a escultora......................................76

4.3 Entre o eu e o outro, a arte: o desenho de Janair .............................. 85

4.4 A barata: uma escultura na escrita.........................................90

4.5 Um possível ready made .................................................94

4.6 A poesia como a pintura, a escultura como a prosa $\ldots \ldots \ldots \ldots \ldots \ldots \ldots \ldots \ldots \ldots \ldots . \ldots 7$

4.7 Exercícios ecfrásticos na Paixão .......................................... 98

$4.8 \mathrm{O}$ inseto versus a empregada; a escultura versus o desenho ........................107

4.9 Nos confins da História: o espaço e o tempo na viagem fantasiosa de G.H...........113 
4.10 A obsessão pela "forma" ................................................. 118

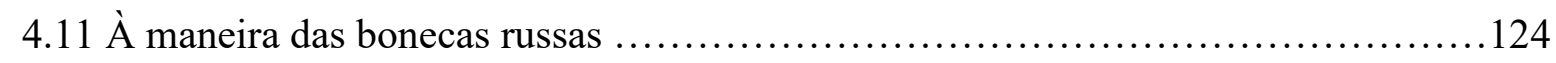

$4.12 \mathrm{Da}$ forma escultórica à forma narrativa ................................... 130

4.13 "Se fosse eu, trabalharia só com as mãos": entre G.H. e Clarice .................... 139

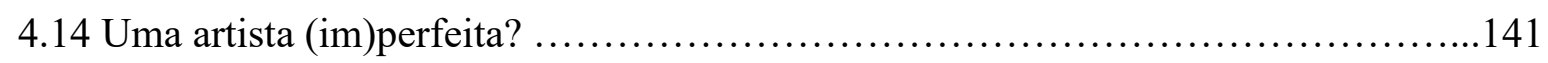

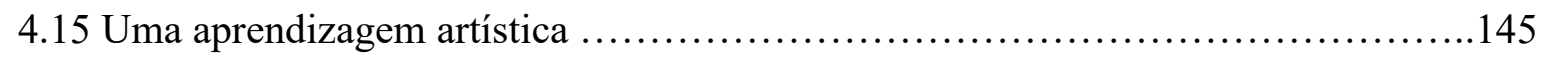

5. Contemplando as esculturas de G.H.: à guisa de conclusão ....................147

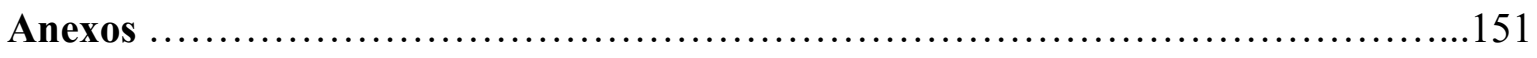

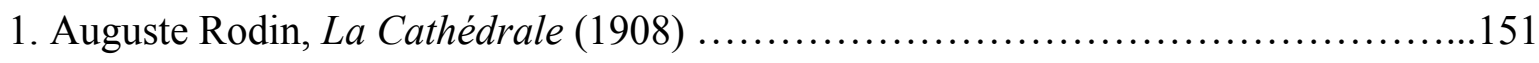

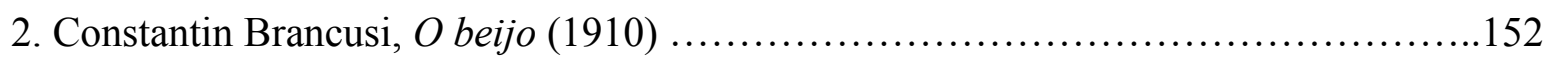

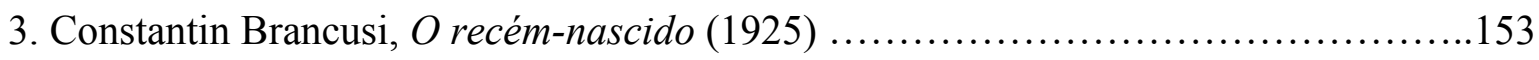

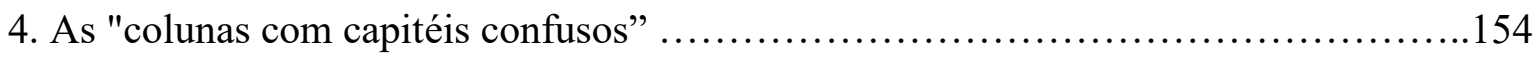

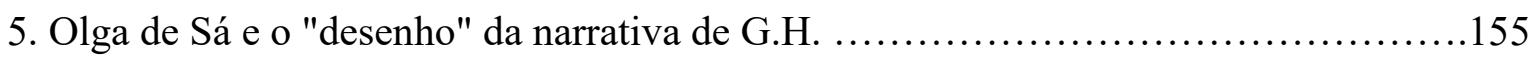

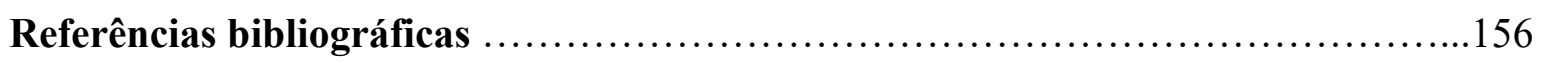




\section{INTRODUÇÃO}

O interesse e a pesquisa em torno de Clarice Lispector demonstram-se inesgotáveis: cada vez mais irrompem-se obras, dissertações e teses a respeito da autora, que, nos últimos anos, parece estar ganhando também um crescente reconhecimento internacional, graças a novas biografias e traduções que fazem ruir as fronteiras da linguagem.

O fenômeno Clarice Lispector parece ganhar força inclusive nas mídias sociais: associada, normalmente, a uma escrita intimista e feminina, diversos são os trechos de suas obras postos em circulação, ao mesmo tempo em que muitos, também, são os textos falsamente atribuídos à autora. Nota-se, assim, certa popularização de páginas na internet sobre literatura e, ainda, um aparente aumento no número de clubes do livro (muitos justamente com a proposta de ler mulheres, incluindo Lispector em suas listas). Esse gradativo interesse do público não acadêmico é importante e talvez dê visibilidade aos estudos rigorosos que, de fato, podem penetrar a complexidade de sua obra.

Evidentemente, esta dissertação se enquadra nessa categoria - a qual já é muito extensa e parece crescer -: a de leitores, estudantes e acadêmicos entusiastas pela obra clariceana, buscando, cada qual a sua maneira, novas chaves de leitura e de interpretação para a vasta produção da autora. Afinal, todo o êxtase em torno de Lispector pode ser resumido no fato de que ela produziu, inegavelmente, uma impressão única na literatura nacional, sendo lida e relida até hoje, ano que marca seu centenário; podendo ter suas obras classificadas como clássicas no âmbito da literatura brasileira, pois todo esse interesse, responsável, em parte, por provocar o vasto estudo sobre a autora, parece demonstrar como seus livros aparentemente ainda não terminaram "de dizer aquilo que tinha para dizer" 2 .

Assim, pode-se esclarecer a leitura que aqui se pretende fazer da obra de Clarice: o intuito desta dissertação é perseguir o tema da arte e do artista em sua obra por meio de textos diversos - que vão das entrevistas com artistas à ficção -, a fím de se deter no estudo pormenorizado de A paixão segundo G.H.. Percorrendo as entrevistas da autora, suas crônicas, seus contos e romances, nota-se como esse assunto é amplamente discutido por ela, que demonstra profundo interesse em conhecer e tocar os âmbitos interartísticos: há evidências da própria escrita, do desenho, da pintura, da escultura e até da música em diversos de seus textos.

\footnotetext{
${ }^{2}$ CALVINO, Italo. Por que ler os clássicos. São Paulo: Companhia de bolso. E-book.
} 
Com isso em mente, pode-se explicar as partes deste estudo. A primeira, que abre a dissertação, pretende traçar uma visão sobre a posição do artista na modernidade, a fim de expandir os estudos sobre o tema na obra clariceana; analisando, assim, textos essenciais da teoria literária a respeito do romance de introversão - vertente do romance na qual se enquadra A paixão segundo G.H., foco deste estudo -; do romance de artista (o Künstlerroman, um subtipo do Bildungsroman, o qual também parece, de alguma forma, descrever o romance em questão); do papel da mulher na sociedade e sobre os atributos essenciais para ela se tornar, enfim, uma artista. Além disso, encontra-se-se, nesta parte, uma breve leitura do romance inaugural de Clarice, Perto do coração selvagem, com o intuito de demonstrar como ele já anunciava certos temas que viriam nas obras posteriores da autora, como o do artista, bem como com o objetivo de apresentar uma discussão atrelada às ideias de Virginia Woolf e de outras críticas a respeito da mulher artista na sociedade - e de como as prisões sociais, com suas regras e normas adstritas ao sexo feminino, interferem na construção de um Bildungsroman (e, possivelmente, Künstlerroman) feminino.

Vale lembrar, além disso, que Clarice não apenas escrevia: ela também se aventurou na pintura, como já estudado, por exemplo, por Carlos Mendes de Sousa ${ }^{3}$ e Ricardo Iannace ${ }^{4}$. No entanto, Clarice não se considerava uma pintora, muito menos considerava seus quadros como arte efetivamente dita, como se nota em uma fala de sua conferência intitulada "Literatura de vanguarda no Brasil":

O que me "descontrai", por incrível que pareça, é pintar, e não ser pintora de forma alguma, e sem aprender nenhuma técnica. Pinto tão mal que dá gosto e não mostro meus, entre aspas, "quadros" a ninguém. É relaxante e ao mesmo tempo excitante mexer com cores e formas, sem compromisso com coisa alguma. É a coisa mais pura que faço. ${ }^{5}$

Interessante que, do mesmo modo que Clarice se considera uma "amadora" na pintura, ela também se considera amadora na escrita, como se nota em sua entrevista a Júlio Lerner:

Eu não sou uma profissional, eu só escrevo quando eu quero. Eu sou uma amadora e faço questão de continuar sendo amadora. Profissional é aquele que tem uma obrigação consigo

\footnotetext{
${ }^{3}$ SOUSA, Carlos Mendes de. Clarice Lispector: Pinturas. Rio de Janeiro: Rocco, 2013.

${ }^{4}$ IANNACE, Ricardo. Retratos em Clarice Lispector: literatura, pintura e fotografia. Belo Horizonte, Minas Gerais: Editora UFMG, 2009.

${ }^{5}$ LISPECTOR, Clarice. "Literatura de vanguarda no Brasil". In: Clarice Lispector: Outros escritos. Org. Teresa Montero e Lícia Manzo. Rio de Janeiro: Rocco, 2005, p. 110.
} 
mesmo de escrever. Ou então com o outro, em relação ao outro. Agora eu faço questão de não ser uma profissional para manter minha liberdade. ${ }^{6}$

Apesar disso, a pintura aparece de forma recorrente nas obras ficcionais de Clarice, bem como a questão do dom e da vocação artísticas - seja para pintar, seja para escrever. Como se verá na segunda parte deste trabalho, "Clarice Lispector: entre a escrita e as artes visuais", Clarice, entrevistando outros artistas, frequentemente perguntava sobre os seus métodos de fazer artístico, parecendo buscar respostas que traduzissem os seus próprios anseios, curiosidades e processos criativos. Nas crônicas, temas sobre diversas artes também aparecem: citando alguns dos mais relevantes, que se analisarão a seguir, Clarice discorria sobre questões como a arte abstrata e a arte figurativa; a contemplação de certos quadros específicos - como Paisagem com pássaros amarelos, de Paul Klee ${ }^{7}$-; seu desejo em abandonar a palavra, se, para a pintura ou o desenho, ela tivesse o dom e a vocação necessários. No entanto, ela própria afirma que seu talento era, na verdade, escrever, mesmo que isso fosse, muitas vezes, uma "maldição, mas uma maldição que salva" ${ }^{8}$. Portanto, nessa segunda parte da dissertação, todas essas questões serão levantadas, a partir de um apanhado de suas entrevistas (no papel de entrevistadora), contos, crônicas e romances, bem como da produção da obra crítica encontrada a respeito desse assunto.

Contudo, o foco principal desta dissertação reside em outra modalidade de manifestação artística: a escultura - que também é procurada dentre os textos analisados na segunda seção deste trabalho. A crítica já parece ter um arcabouço sólido sobre o estudo da pintura em Clarice Lispector (analisando as crônicas, contos e romances, principalmente Água viva, o qual apresenta uma narradora-pintora), porém não parece ter se debruçado (a não ser de modo muito breve) sobre a presença da escultura na escrita clariceana. Clarice entrevistou diversos escultores, como se destaca na segunda parte deste trabalho, e também escreveu textos que versam sobre o assunto - como a complexa crônica "Uma porta abstrata" ${ }^{9}$, que relaciona a arte escultórica ao interesse essencial de Clarice em "tocar a coisa", alcançar o âmago do mundo (nomeado, em suas obras, como o neutro, ou o it.). Ainda, sua primeira protagonista efetivamente artista é uma escultora: G.H., de A paixão segundo G.H., romance que constitui o núcleo fundamental desta dissertação. A terceira parte ("A escultura

\footnotetext{
${ }^{6}$ C.f.: LISPECTOR, Clarice. Panorama com Clarice Lispector. Entrevista concedida a Júlio Lerner. São Paulo: TV Cultura, 1977. Disponível em: https://www.youtube.com/watch?v=ohHP112EVnU.

${ }^{7}$ LISPECTOR, Clarice. "Medo da libertação". In: A descoberta do mundo. Rio de Janeiro: Rocco, 2009, p. 198.

${ }^{8}$ LISPECTOR, Clarice. "Escrever". Ibidem, p. 134.

${ }^{9}$ LISPECTOR, Clarice. "Uma porta abstrata". In: Todas as crônicas. Rio de Janeiro: Rocco, 2018, p. 657.
} 
na ficção clariceana: três exemplos comparados"), a quarta ("A paixão segundo G.H.: a transgressão do artista") e a quinta ("Contemplando as esculturas de G.H.: à guisa de conclusão") visam estudar, assim, o papel da escultura na ficção clariceana, primeiro comparando o romance de 1964 com outros dois textos nos quais a escultura também é presente - o conto "A quinta história" e o romance $O$ lustre - e, por fim, analisando o papel dessa arte essencialmente tátil (e buscando possíveis "esculturas" da protagonista na narrativa) em A paixão segundo G.H.. Procura-se dialogar, sempre que necessário, com alguns dos críticos clariceanos imprescindíveis na leitura desse romance - o que, conforme Calvino, parece fazer dele também um clássico, uma vez que é impossível ler Clarice e essa obra sem pensar ao menos em alguns autores fundamentais que tanto se aprofundaram na interpretação de seus escritos. Tal romance de fato chega "até nós trazendo consigo as marcas das leituras que precederam a nossa e atrás de si os traços que deixaram na cultura ou nas culturas que atravessaram (ou mais simplesmente na linguagem ou nos costumes)"10.

Finalmente, espera-se, com todo esse trabalho - além de elucidar uma leitura dos escritos de Clarice procurando relações com a escultura -, contribuir ao menos de forma pequena para a volumosa fortuna crítica dos estudos clariceanos, que parece florescer cada vez mais conforme o passar do tempo. Claramente, é impossível abarcar tudo o que se refere à escultura e aos estudos interartes na obra de Clarice Lispector neste curto período de dois anos e meio de Mestrado, que resultou nessas pouco mais de cem páginas a respeito do tema. Mas, se a obra clariceana já pode ser considerada como clássica, pode-se julgar que cada vez mais haverá leituras "novas, inesperadas, inéditas"11 acerca de seus livros; logo, o intuito deste trabalho: ser apenas o início de uma jornada de pesquisa.

\footnotetext{
${ }^{10}$ CALVINO, op. cit.

${ }^{11}$ Ibidem.
} 


\section{O ARTISTA NA MODERNIDADE}

\subsection{O romance de introversão e o romance de artista}

Ao longo do século XIX, o romance se estabeleceu como um gênero de variedade, alcance e profundidade inigualáveis. Os movimentos romântico, realista e naturalista contribuíram, todos eles, depositando seus aluviões em suas margens, assim compondo aqueles contornos familiares que agora tomamos por assentes. Na virada do século, portanto, parecia não haver mais espaço para que esse refinado meio de expressão se desenvolvesse, pois ele voltou-se para si mesmo. Entre alguns dos seus mais importantes praticantes, aumentou acentuadamente o grau de apresentação auto-analítica do romance, intensificaram-se suas obsessões com sua própria tática de esquematização e estruturação; ele se tornou marcadamente mais "poético", no sentido em que passou a se dedicar mais à precisão da forma e composição, a se incomodar mais com a vagueza da prosa em seu uso popular escrito. De tudo isso resultou uma revolução radical na técnica e uma ênfase muitíssimo maior sobre a forma, e as consequências disso ainda estão muito presentes entre nós $(\ldots) .^{12}$

O trecho em questão é o início de um ensaio de John Fletcher e Malcolm Bradbury a respeito do romance de introversão. Neste texto, os autores elucidam as características de uma das tendências do romance moderno: nessa vertente metalinguística, nota-se que há certo "gosto por formas que, voltando-se sobre si mesmas, mostram o processo de construção do romance e reproduzem os meios com que se realiza a própria narração"13.

No século XX, diversas são as mudanças observadas no romance - dentre as mais importantes, citam-se as mais comentadas pelos críticos: a instauração do fluxo de consciência e do monólogo interior ${ }^{14}$; a complexidade da posição do narrador em uma época na qual não se poderia mais narrar, graças à desintegração da "identidade da experiência, a vida articulada e em si mesma contínua, que só a postura do narrador permite"15; a retomada do aperspectivismo não só na pintura, mas de certa forma também na literatura, com a eliminação do tempo cronológico $^{16}$; a volta ao mito, devido justamente à relativização

\footnotetext{
12 FLETCHER, John; BRADBURY, Malcolm. "O romance de introversão". In: BRADBURY, Malcolm; MCFARLANE, James (org). Modernismo: guia geral 1890-1930. São Paulo: Companhia das Letras, 1989, p. 322, grifos meus.

13 Ibidem, p. 323, grifos meus.

14 C.f.: AUERBACH, Erich. "A meia marrom". In: Mimesis - A representação da realidade na literatura ocidental. São Paulo: Perspectiva, 2013, p. 471- 498.

15 ADORNO, Theodor. "Posição do narrador no romance contemporâneo". In: Notas de literatura I. São Paulo: Duas Cidades; Editora 34, 2012, p. 55.

${ }^{16}$ ROSENFELD, Anatol. "Reflexões sobre o romance moderno". In: Texto/Contexto I. São Paulo: Perspectiva, 1996, p. 75-97.
} 
temporal nas narrativas e à crise do romance psicológico ${ }^{17}$. Essas são algumas das novidades notadas no romance da virada do século, e é precisamente nesse mesmo tempo conflituoso que ganha força a tendência do romance de introversão.

Por ser um tipo de romance no qual a narrativa versa sobre si mesma, especulando e deixando evidente as suas estratégias e seus caminhos de construção, Fletcher e Bradbury notam que um de seus principais temas é a própria arte - conforme Nabokov, citado pelos autores no ensaio referido, "a propósito de um romance escrito por uma de suas próprias personagens, diz bem: '(...) os heróis do livro são o que se pode chamar vagamente de métodos de composição" ${ }^{18}$. Consequentemente, já que a introversão narrativa deixa claro os processos de escrita da obra, também se pode notar explicitamente nessa tendência do romance aquele que o cria: o artista - no caso da arte da palavra, o escritor. Tanto a própria estética quanto o seu criador são postos em jogo, resultando em uma "extremada consciência literária" ${ }^{19}$ própria dessas narrativas.

Muitos são os exemplos que se pode lembrar dessa tendência narrativa - citam-se, aqui, apenas os mesmos referidos por Fletcher e Bradbury: Em busca do tempo perdido de Proust, com o protagonista Marcel; Tonio Kröger, de Thomas Mann, cujo protagonista leva o mesmo nome da obra; Retrato do artista quando jovem e Ulysses, ambos de James Joyce e ambos apresentando o personagem Stephen Dedalus; Os moedeiros falsos, de André Gide, com o personagem Édouard. Todos esses são romances de introversão que apresentam o tema da arte - no caso, da escrita - com personagens escritores.

Portanto, nota-se como o romance de introversão apresenta uma propensão metalinguística: o tema da própria arte do romance e do artista são fortemente presentes nessa tendência narrativa da modernidade. Além disso, nesse percurso, cabe destacar que o tema do artista, na teoria literária, é também considerado como uma linha específica do Bildungsroman, intitulada Künstlerroman. Herbert Marcuse, em 1922, cunha o termo (que, em português, significa justamente "romance de artista") em sua tese de doutorado, ao estudar a constância dessa característica na literatura alemã.

Em A teoria do romance, Georg Lukács define o Bildungsroman ${ }^{20}$, ou o romance de educação (usando seus termos nessa obra), como "conduzido e direcionado por um

\footnotetext{
${ }^{17}$ ROSENFELD, Anatol. "À procura do mito perdido: notas sobre a crise do romance psicológico". In: Letras e leituras. São Paulo: Perspectiva, p. 21-32.

18 FLETCHER \& BRADBURY, 1989, p. 322, grifos meus.

${ }^{19}$ Ibidem, p. 329.

${ }^{20}$ Sem se adentrar, aqui, profundamente nas muitas discussões a respeito da complexidade de se caracterizar propriamente o romance de formação, principalmente na modernidade, é importante retomar, mesmo que
} 
determinado objetivo: o desenvolvimento de qualidades humanas que jamais floresceriam sem uma tal intervenção ativa de homens e felizes acasos; pois o que se alcança desse modo é algo por si próprio edificante e encorajador aos demais, por si próprio um meio de educação"21. O que se pode levar à constatação, como o fez Mikhail Bakhtin, de que nesse tipo de romance:

se fornece a unidade dinâmica da imagem da personagem. O próprio herói e seu caráter se tornam uma grandeza variável na fórmula desse romance. A mudança do próprio herói ganha significado de enredo e em face disso reassimila-se na raiz e reconstrói todo o enredo do romance. O tempo se interioriza no homem, passa a integrar a sua própria imagem, modificando substancialmente o significado de todos os momentos do seu destino e da sua vida. Esse tipo de romance poder ser designado no sentido mais amplo como romance de formação do homem. ${ }^{22}$

Esse herói do Bildungsroman, que move, portanto, todo o enredo do romance, modificando-o profundamente, tornando-o não mais um romance estático com personagens prontas (usando os termos de Bakhtin), mas uma narrativa cujo desenvolvimento depende dos rumos do protagonista, de suas mudanças e de sua evolução; esse personagem central que se forma e se educa frente ao mundo e aos acasos que perpassam seu caminho deseja, sobretudo, "querer realizar, de algum modo, o âmago de sua interioridade no mundo"23. É a isso que Lukács chama, justamente, de educação: a progressão do herói em uma narrativa cujo percurso poderá servir de impulso aos demais homens, graças ao resultado profícuo que sua alma, em desenvolvimento constante nesse tipo de romance, alcança. E, como se pode ver em algumas amostras dentre os inúmeros Bildungsroman que são tão citados e estudados até a contemporaneidade ${ }^{24}$, muitas vezes essa aspiração será frustrada, dada a posição desse personagem na sociedade moderna, espaço das "culturas problemáticas" ${ }^{25}$, o que pode levar a um rompimento entre o personagem e sua comunidade e, consequentemente, à solidão final do herói. Lukács chama atenção para esse fato:

brevemente, o conceito e os estudos acerca do Bildungsroman para se chegar, enfim, à sua ramificação, o Künstlerroman.

${ }^{21}$ LUKÁCS, Georg. A teoria do romance: um ensaio histórico-filosófico sobre as formas da grande épica. São Paulo: Duas Cidades; Editora 34, 2009, p. 141.

22 BAKHTIN, Mikhail. "O romance de educação e sua importância na história do realismo". In: Estética da criação verbal. São Paulo: Editora WMF Martins Fontes, 2011, p. 219-220.

${ }^{23}$ LUKÁCS, 2009, p. 142.

${ }^{24}$ Lukács apenas faz essa afirmação sobre a solidão, não a estuda propriamente em $A$ teoria do romance, uma vez que sua atenção será voltada à análise de Os anos de aprendizado de Wilhelm Meister. Entretanto, como aqui se tentará mostrar, a solidão e a insubmissão são frutos, principalmente, dos personagens artistas, como defenderá Marcuse.

${ }^{25}$ Termo utilizado por Lukács em A teoria do romance, em contraposição ao mundo da épica, das "culturas fechadas". 
o advento final do herói a uma solidão resignada não significa um colapso total ou a conspurcação de todos os ideais, mas sim a percepção da discrepância entre interioridade e mundo, uma realização ativa da percepção dessa dualidade: a adaptação à sociedade na resignada aceitação de suas formas de vida e o encerrar-se em si e guardar-se para si da interioridade apenas realizável na alma. ${ }^{26}$

A solidão do herói, que é passível de ocorrer em alguns desses romances, dado o insucesso da relação entre eu e mundo, fazendo-o se recolher em si mesmo, não é, na visão de Lukács, um colapso de sua formação nem do romance, mas apenas uma causalidade. $\mathrm{O}$ personagem nem sempre irá aceitar e se conformar com os mandos da sociedade, vivendo plenamente conforme as regras que ela dita. E, por isso, a solidão, mesmo que resignada, preencheria esses sujeitos.

São propriamente essas circunstâncias de insatisfação com a sociedade - mesmo que, por vezes, possa haver certa condescendência do herói - e a consequente solidão do personagem, as quais Lukács nota que podem estar presentes no Bildungsroman, que Herbert Marcuse retoma para determinar o seu estudo sobre o Künstlerroman. De acordo com Marcuse, o romance de artista só existe quando a subjetividade do herói, cuja trajetória encaminha-se para a experiência do artista, mostra-se inconciliável em face da sociedade: assim ele caracteriza, idealmente, o artista, que, descontente, impõe-se ao mundo à sua volta, vivendo à margem de sua comunidade, contra os seus mandos e, logo, em solidão. Tal seria a forma de vida peculiar desse sujeito, e é precisamente esse aspecto que o Künstlerroman apresentaria como cerne de sua narrativa:

o romance apresenta um panorama histórico de estados e ocupações separados por meio de personagens representativos - o romance de artista seria, assim, o romance no qual um artista é tratado em seu meio e possuindo um tipo de vida característico. Por isso o lugar histórico do romance de artista dentro da arte literária épica: ele só é possível se a verdadeira existência do artista significa ter um estilo de vida peculiar, incongruente com aquele das pessoas em geral, isto é, quando a arte não é mais expressão imanente e necessária da vida compreensível da comunidade. ${ }^{27}$

\footnotetext{
${ }^{26}$ LUKÁCS, 2009, p. 142-143.

27 Tradução livre de: "the novel presents an historical picture of separate estates and occupations through representative characters - the artist novel would thus be a novel in which an artist is treated in his milieu and as possessing a characteristic type of life. Hence the historical place of the artist novel within epic literary art: it is only possible if the very being of an artist means having a peculiar type of life, not congruent with that of people in general, that is, when art is no longer the immanent and necessary expression of the comprehensive life of the community". MARCUSE, Herbert. "The German Artist Novel: Introduction". In: KELLNER, Douglas (org). Art and liberation-Collected papers of Herbert Marcuse, vol. 4. Nova Iorque: Routledge, 2007, p. 72, grifos meus.
} 
Quando o artista, que demandou que sua individualidade tinha o direito a uma vida própria, deixa, então, o mundo que o cerca, ele suporta a maldição de uma cultura na qual Ideia e realidade, arte e vida, sujeito e objeto, fiquem em forte oposição uma com a outra. Ele não acha qualquer satisfação nas formas de vida do mundo que o cerca, com todas as suas limitações; sua autêntica personalidade e seus desejos não encontram ressonância ali; $\mathrm{em}$ solidão ele fica contra a realidade. É aqui que o romance de artista se põe a trabalhar. ${ }^{28}$

Essa dicotomia entre eu e mundo, levando o artista a ter uma vida discrepante aos outros e dando origem e matéria ao Künstlerroman, leva o sujeito à procura de uma solução: de alguma maneira, segundo Marcuse, ele seria impelido a buscar "uma nova unidade (...) uma vez que essa contradição é tão dolorosa que, a longo prazo, é insustentável sem a destruição do artista e da humanidade"29. Por isso o Künstlerroman ser um subtipo do Bildungsroman: nesse empenho de tentar pertencer novamente à unidade social, há, de alguma forma, o "desenvolvimento da autoconsciência e de um modo de vida essencialmente estético"30.

A busca por pertencimento leva, então, a duas formas de narrativa do artista, as quais se originam de acordo com o modo pelo qual se resolverá o abismo entre eu e mundo. Imaculada Kangussu retoma, com exemplos, esses dois modos de resolução propostos na tese de Marcuse: "(1) a integração triunfante de Wilhelm Meister, de Goethe, e de Der grune Heinrich, de Keller; ou (2) a desintegração final de Gustav Von Aschenbach, em A morte em Veneza, de Mann"31. Ou seja: pode-se ocorrer, no Künstlerroman, a volta do personagem artista à sociedade, como ocorre com Wilhelm Meister após sua experiência como artista; ou a própria ruína resultante da impossibilidade de conciliação entre eu e mundo, o que, a exemplo de Aschenbach, "parece por em questão a viabilidade da integração do artista à sociedade burguesa" ${ }^{32}$. Seja como for, o que há no romance de artista é, ao menos, uma breve experiência do sujeito em caminhar distante e conflituosamente em face das convenções sociais; um conhecimento, mesmo que mínimo, sobre o que é ser artista e não conseguir resolver o impasse essencial: a "incongruência" (retomando o termo de Marcuse) com o

\footnotetext{
${ }^{28}$ Tradução livre de: "When the artist, who had demanded that the private self had a right to a life of its own, then steps out into the surrounding world, he endures the curse of a culture in which Idea and reality, art and life, subject and object, stand in stark opposition to one another. He finds no fulfillment in the surrounding world's forms of life with all their limitations; his authentic self and his desires find no resonance there; in solitude he stands against reality. Here is where the artist novel sets itself to work." Ibidem, p. 78, grifos meus. 29 Tradução livre de: "a new unity (...), because this contradiction is so painful that in the long run it is unbearable without destroying the artist and the humanity". Ibidem, p. 78.

${ }^{30}$ KANGUSSU, Imaculada. "Sobre a alteridade do artista em relação ao mundo que o cerca, segundo Herbert Marcuse". Revista Kriterion, Belo Horizonte, n. 112, dez./2005, p. 364.

${ }^{31}$ Ibidem, p. 352.

${ }^{32}$ Ibidem, p. 355.
} 
mundo a sua volta. Importante notar que, desse segundo tipo de Künstlerroman, o qual retrata a impraticabilidade da harmonia entre artista e sociedade, o exemplo maior é justamente um romance da modernidade, escrito já no século XX; em contraposição com os romances que caracterizariam a resignação do artista à sociedade burguesa - os quais datam do final do século XVIII e do XIX. Lukács explica, em seu texto "O romance como epopeia burguesa"33, que essa submissão final do protagonista - chamado de "herói-filisteu positivo" termo que ele retoma de Hegel -, a exemplo de Wilhelm Meister de Goethe, servia justamente para disfarçar e conciliar as contradições da sociedade burguesa. A isso Lukács define como "uma fantástica e geralmente reacionária utopia do 'meio termo'": uma "exigência hegeliana de que o romance suscite no leitor o respeito pela realidade burguesa" ${ }^{34}$ - por isso a reconciliação final de Wilhelm Meister com a sociedade. No entanto, essa imposição feita para os autores do século XIX se revela cada vez mais falaciosa, uma vez que, ao representar a burguesia e seu cotidiano, mesmo com o herói "positivo", representa-se também, de certa forma, todas as suas contradições, o que leva os escritores, com o passar do século, a notarem a impraticabilidade de se criar esse tipo de personagem: "Quanto mais profundamente o artista descobre as contradições da sociedade burguesa, quanto mais cruamente desmascara a baixeza e a hipocrisia da sociedade capitalista, tanto menos realizável se torna a cínica exigência de Hegel de um herói-filisteu 'positivo'"'35. Parece que seria, então, inviável ao artista moderno viver em concordância com a estrutura social e suas substanciais regras.

\subsection{A condição feminina}

No mesmo ano em que Marcuse defendia sua tese a respeito do Künstlerroman, em 1922, uma das maiores obras do Modernismo em língua inglesa foi lançada: Ulysses, de James Joyce. Neste romance, Joyce retrata a perambulação de um dos protagonistas, Leopold Bloom, em um dia na capital irlandesa. O outro protagonista é justamente o artista do romance inaugural de Joyce: Stephen Dedalus, que, em Ulysses, retorna já adulto à Dublin devido à morte da mãe.

Concomitantemente, também na Europa (mais especificamente no Reino Unido), surge outra das maiores personalidades da literatura modernista em língua inglesa: Virginia

\footnotetext{
${ }^{33}$ In: Ad Hominem 1 - Revista de Filosofia, politica, ciência da história. Tomo II: Música e literatura. Inujuí, RS: Editora Unijuí, 1999, p. 87-117.

${ }^{34}$ Ibidem, p. 108.

${ }^{35}$ Ibidem.
} 
Woolf. Integrante do polêmico Grupo de Bloomsbury, a escritora tomou contato com diversos artistas e pensadores renomados da época, bem como participou e iniciou discussões também das mais importantes nas artes - como a posição da literatura de seu tempo e a urgência de se ter condições favoráveis à mulher para ela poder, finalmente, ascender ao mundo artístico. Virginia Woolf era conhecedora, inclusive, de seu coetâneo Joyce, sobre o qual escreveu, desgostosamente, em um de seus ensaios sobre as obras literárias contemporâneas: "Ulysses foi uma memorável catástrofe - imenso na ousadia, terrificante no malogro" ${ }^{\prime 36}$. Curioso pensar que esses dois escritores, apesar de tão diferentes (como se vê, além das obras deixadas por cada autor, nessa própria afirmação de Woolf) são recorrentes na comparação com a obra de Clarice Lispector, como se pode perceber em sua fortuna crítica.

Enquanto Ulysses narra as idas e vindas de um protagonista homem em Dublin em um único dia, um dos tópicos centrais do pensamento de Woolf é exatamente a impossibilidade da mulher realizar o simples ato que, no caso de Leopold Bloom, não seria marcado por nenhum tipo de impedimento: vaguear espontaneamente pela cidade. Em outro ensaio, Woolf ironicamente confessa seu imenso desejo em comprar um lápis - objetivo que esconde, na verdade, a vontade da mulher em simplesmente sair do ambiente doméstico em direção às ruas:

Talvez ninguém nunca tenha sentido tanta paixão por um lápis. Mas há circunstâncias em que pode ser supremamente desejável possuir um; momentos em que nos dispomos a ter um objeto, tendo assim um objetivo, um pretexto para andar pela metade de Londres entre o chá e o jantar. Como um caçador de raposas caça para preservar a linhagem dos cavalos, e o golfista joga para que espaços abertos possam ser preservados da ação das construtoras, assim, quando o desejo de sair perambulando pelas ruas nos vence, o lápis bem que serve de pretexto, e levantamo-nos dizendo: "Realmente eu preciso comprar um lápis", como se com essa desculpa por disfarce pudéssemos fruir com segurança do maior prazer da vida da cidade no inverno - perambular pelas ruas de Londres. ${ }^{37}$

Colossal diferença entre o personagem de Ulysses e a narradora do ensaio: ela, assim como qualquer outra mulher, havia de encontrar uma desculpa a fim de poder flanar pela cidade. Ao sexo feminino, estavam impostos os cuidados exclusivos com o lar, com o casamento e com a maternidade; e impedidas as saídas à rua, a conquista do trabalho e de mais tantos outros direitos que eram exclusivamente masculinos até então. Essa diferença

\footnotetext{
${ }^{36}$ WOOLF, Virginia. "Como impressionar um contemporâneo". In: O valor do riso e outros ensaios. São Paulo: Cosac Naify, 2014, p. 124.

37 WOOLF, Virginia. "Batendo pernas nas ruas: uma aventura em Londres". In: O valor do riso e outros ensaios. São Paulo: Cosac Naify, 2014, p. 225.
} 
entre gêneros é trabalhada por Woolf em muitos de seus ensaios: diversos são aqueles em que argumenta a necessidade de conquista do espaço público pelo sexo feminino especialmente para a mulher dominar, também, o mundo artístico. Como, então, poderia a mulher, confinada em sua casa, desenvolver-se nas artes, mais especificamente tornar-se romancista, especialmente agora, na modernidade - era em que, mais do que nunca, o homem e, consequentemente, o artista (especialmente o escritor), estavam, segundo Woolf, tão "expostos à vida"?

O romancista - tal é seu mérito e seu risco - está tremendamente exposto à vida. Outros artistas se recolhem, pelo menos em parte; fecham-se sozinhos por semanas a fio como uma travessa de maçãs e uma caixa de tintas, ou com um rolo de pautas musicais e um piano. Quando saem, é para esquecer e se distrair. Mas o romancista nunca esquece e raramente se distrai. Enche o copo e acende o cigarro, provavelmente goza de todos os prazeres da conversa e da mesa, mas sempre com a sensação de que está sendo estimulado e manipulado pelo tema de sua arte. Sabores, sons, movimentos, algumas palavras aqui, um gesto ali, um homem entrando, uma mulher saindo, mesmo o automóvel que passa na rua ou o mendigo que se arrasta pela calçada, e todos os vermelhos, azuis, luzes e sombras da cena pedem sua atenção e despertam sua curiosidade. É-lhe impossível deixar de receber impressões, assim como é impossível a um peixe no oceano deixar de ter a água passando pelas guelras. ${ }^{38}$

Essa privação à mulher de se expor à vida, ao público e às ruas - que a impede, como ocorre com a narradora teoricamente em busca do lápis, de poder andar sem escrúpulos pela Oxford Street, pela Strand, pelas margens do Tâmisa e, assim, presenciar o espírito londrino no espaço aberto -, incide justamente na diferença entre a arte dos homens e a arte das mulheres. De modo semelhante refletiu Gilda de Mello e Souza, notando como a literatura feminina - e, portanto, a clariceana, que teria tido êxito em captar formalmente esse aspecto - tenderia a focalizar a miudeza da vida feminina confinada em casa, o que ela denomina como a "visão de míope":

Não será difícil apontar na literatura feminina a vocação da minúcia, o apego ao detalhe sensível na transcrição do real, características que, segundo Simone de Beauvoir, derivam da posição social da mulher. Ligada aos objetos e dele dependendo, presa ao tempo, em cujo ritmo se sabe fisiologicamente inscrita, a mulher desenvolve um temperamento concreto e terreno, movendo-se como coisa num universo de coisas, como fração de tempo num universo temporal. A sua é uma vida refletida, sem valores, sem iniciativa, sem acontecimentos de relevo, e os episódios insignificantes que a compõem, de certo modo só ganham sentido no passado, quando a memória, selecionando o que o presente agrupou sem escolha, fixa dois ou três momentos que se destacam em primeiro plano. Assim, o universo feminino é um universo de lembrança ou de espera, tudo vivendo, não de um sentido imanente mas de um valor atribuído. E como não lhe permitem a paisagem que se desdobra

\footnotetext{
${ }^{38}$ WOOLF, Virginia. "A vida e o romancista". In: A arte do romance. São Paulo: L\&PM Pocket, 2018, p. 85, grifos meus.
} 
para lá da janela aberta, a mulher procura sentido no espaço confinado em que a vida se encerra: o quarto com os objetos, o jardim com as flores, o passeio curto que se dá até o rio ou a cerca. A visão que constrói é por isso uma visão de míope, e no terreno que o olhar baixo abrange, as coisas muito próximas adquirem uma luminosa nitidez de contornos. ${ }^{39}$

Woolf debatia pública e frequentemente o assunto com críticos literários homens que, exaustivamente, insistiam em taxar a literatura de autoria feminina como inferior à masculina, rotulando, de diversas maneiras, as produções do outro sexo; e argumentava, justamente, que essa diferença nas artes procedia diretamente das desiguais posições dos gêneros na sociedade de acordo com as regras instituídas:

Como Mr. Brimley Johnson nota várias vezes, a escrita de uma mulher é sempre feminina; não pode deixar de ser feminina; nos melhores casos, é extremamente feminina: o único problema é definir o que queremos dizer com "feminina". Ele se mostra sensato não só ao apresentar inúmeras sugestões, mas também ao aceitar o fato, por desconcertante que seja, de que as mulheres podem variar. Mesmo assim, eis algumas tentativas: "As mulheres são pregadoras inatas e sempre trabalham por um ideal". "A mulher é uma realista moral, e seu realismo não se inspira em nenhum ideal de arte, e sim de afinidade com a vida". Mesmo com toda a sua erudição, "a perspectiva de George Eliot se mantém totalmente emotiva e feminina". As mulheres são mais cômicas e satíricas do que imaginativas. Têm um maior senso de pureza emocional do que os homens, mas um senso de humor menos alerta.

(...) em primeiro lugar, há a enorme e óbvia diferença de experiências; mas a diferença essencial não é que os homens descrevam batalhas e as mulheres o nascimento dos filhos, e sim que cada sexo descreve a si mesmo. ${ }^{40}$

Dado, então, que a escrita das mulheres descreve "o nascimento dos filhos" e que isso seria um fruto do que elas próprias vivenciam em seu papel social, ao passo que o homem descreve "batalhas", Woolf se empenha em pensar e exprimir, em sua obra (particularmente nos ensaios), aquilo que é necessário à mulher para que ela possa se equiparar à experiência masculina e, assim, desenvolver-se plenamente nas artes: em resumo, de acordo com a autora, seriam necessários "tempo livre e dinheiro e um quarto só para si" ${ }^{41}$. Em outras palavras, aquilo que pertencia socialmente ao masculino: tempo livre, desprendendo-se por momentos de seus afazeres domésticos; dinheiro, a conquista do ambiente de trabalho fora de casa; e um espaço para si, onde ela poderia se entregar às ocupações artísticas e esquecer, ao menos por alguns instantes, das ocupações até então exclusivas com o lar, o casamento e a maternidade.

\footnotetext{
${ }^{39}$ SOUZA, Gilda de Mello e. "O vertiginoso relance". In: Exercícios de leitura. São Paulo: Duas cidades, 1980, p. 79.

${ }^{40}$ WOOLF, Virginia. "Mulheres romancistas". In: A arte do romance. São Paulo: L\&PM Pocket, 2018, p. 2930 , grifos meus.

${ }^{41}$ WOOLF, Virginia. "Mulheres e ficção". In: FRÓES, Leonardo (org). O valor do riso e outros ensaios. São Paulo: Cosac Naify, 2014, p. 283.
} 
Ao menos uma dessas três necessidades já estava sendo conquistada pela mulher no século XX: o trabalho - e, consequentemente, o dinheiro próprio. Woolf também nota como principalmente a Primeira Guerra Mundial foi importante para expandir esse campo ao sexo feminino, e como a independência financeira estaria atrelada diretamente à independência e ao florescimento intelectual das mulheres. Em seu famoso Um teto todo seu, ela escreve:

A liberdade intelectual depende de coisas materiais. A poesia depende da liberdade intelectual. E as mulheres sempre foram pobres, não só por duzentos anos, mas desde o começo dos tempos. As mulheres gozam de menos liberdade intelectual do que os filhos dos escravos atenienses. As mulheres, portanto, não tiveram a mais remota chance de escrever poesia. É por isso que dei tanta ênfase ao dinheiro e ao espaço próprio. No entanto, graças à labuta das mulheres obscuras do passado, de quem eu gostaria de saber mais, graças, curiosamente, a duas guerras - a da Crimeia, que permitiu que Florence Nightingale saísse de casa, e a Europeia, que abriu as portas para a mulher comum cerca de sessenta anos mais tarde -, esses males estão prestes a ser corrigidos. Não fosse assim, vocês não estariam aqui esta noite, e a sua chance de ganhar quinhentas libras por ano, por mais precária que ainda seja, seria extremamente minúscula. ${ }^{42}$

O caminho para o trabalho fora do lar é desatravancado ao sexo feminino no século $\mathrm{XX}$, e a mulher do pós-guerra pode, enfim, enxergar ao menos um pequeno lampejo de conquista do espaço público e de outros direitos civis - consequência de preciosas mudanças que já vinham ocorrendo no final do século anterior:

(...) posso lembrá-las de que há pelo menos duas faculdades para mulheres na Inglaterra desde 1866; que, a partir de 1880, foi permitido por lei que a mulher casada tivesse posse de sua propriedade; e que em 1919 - apenas nove anos atrás - a ela foi dado o voto? Posso lembrar também que a maioria das ocupações está acessível a vocês já faz quase dez anos? Ao refletir sobre esses imensos privilégios e o período de tempo durante o qual tem sido possível desfrutá-los, e o fato de que deve haver, neste exato momento, umas duas mil mulheres capazes de ganhar mais de quinhentas libras por ano de um jeito ou de outro, vocês hão de concordar que a desculpa da falta de oportunidade, instrução, encorajamento, lazer ou dinheiro não mais se sustenta. Além do mais, os economistas nos dizem que a senhora Seton teve filhos demais. Vocês devem, é claro, continuar a ter filhos, mas, segundo eles dizem, dois ou três, e não doze ou treze. ${ }^{43}$

Assim, no século XX, apesar dos percalços ainda existentes na sociedade quanto ao sexo feminino e à sua conquista plena das ruas, a mulher já podia vislumbrar, mesmo que minimamente (ou ao menos discutir as possibilidades desse vislumbre), condições mais favoráveis ao seu desenvolvimento artístico. Apesar de ainda não poder sair às ruas irrestritamente, em liberdade e sem desculpas, a ela já estavam sendo permitidos certos

\footnotetext{
${ }^{42}$ WOOLF, Virginia. Um teto todo seu. São Paulo: Tordesilhas, 2014, n.p. [e-book].

${ }^{43}$ Ibidem.
} 
empregos, vagas em universidades, posses de propriedades e o voto político. A mulher que falsamente procurava o lápis andando pelas ruas londrinas já estava vivendo em uma sociedade na qual as regras impostas ao gênero feminino estavam passando por modificações, mesmo que lentas e ainda não absolutas.

$\mathrm{O}$ assunto da mulher moderna e de suas ocupações para além do lar ganhou o mundo, mesmo que de formas diferentes em cada local. Discussões a respeito de seu progresso na sociedade, saindo da exclusividade da casa, foram travadas também no Brasil. Semelhantemente a Virginia Woolf, a então estudante Clarice Lispector, no seu terceiro ano da faculdade de Direito, propõe uma enquete a seus colegas com o tema "Deve a mulher trabalhar?". Dessa enquete, Clarice escreve um texto ponderando também sobre a nova condição da mulher: em concordância, despropositadamente, com os pensamentos de Woolf, ela reflete como a mulher deve de fato conquistar o espaço público, principalmente após a Primeira Guerra Mundial - tal qual Woolf aponta -, decidindo livremente seu caminho no contexto da então "instabilidade da vida moderna". Se, então, seu desejo for pelo caminho das artes, que este seja, também, por ela escolhido e conquistado sem impedimentos.

Tornou-se velho o problema da mulher, embora date apenas da Grande Guerra, tanto foi ele visado e estudado. Deve ou não deve ela estender suas atividades pelos vários setores sociais? Deve, ou não, voltar suas vistas também para fora do lar? De um lado - apresentase-nos ela seguindo apenas seu eterno destino biológico, e de outro - a nova mulher, escolhendo livremente seu caminho.

De um lado, a casa, compreendendo filhos e marido, exigindo abnegação constante. De outro, a evolução dos costumes e dos ideais, lançando-a no conhecimento de si mesma e de suas possibilidades. Num momento de crise, haviam apelado para o seu auxílio. Sua reação surpreendeu o mundo e, sobretudo, a ela mesma, provando-lhe qualquer coisa de absolutamente novo: a mulher também "pode". (...)

A mulher moderna estuda. Trabalha. E, suas faculdades despertas e desenvolvidas, constitui seu lar, guiando conscientemente seus filhos. As legislações trabalhistas mais adiantadas abrem um capítulo regulador de suas atividades. Aceita-se a nova ordem que, afinal, se trouxe à mulher a alegria de um pouco de liberdade e, sem dúvida, alguns males, também, não foi por ela provocada, mas pelos acontecimentos mundiais e pela consequente instabilidade da vida moderna. ${ }^{44}$

\footnotetext{
${ }^{44}$ LISPECTOR, Clarice. "Deve a mulher trabalhar?". In: Outros escritos. Rio de Janeiro: Rocco, 2015, p. 5051.
} 


\subsection{Bildungsroman feminino}

Não à toa, o Bildungsroman é descrito frequentemente como um fenômeno masculino ${ }^{45}$. Como nota Cristina Oliveira Pinto, "embora tivesse havido sempre 'romances de aprendizagem' feminina, essa aprendizagem se restringia à preparação da personagem para o casamento e a maternidade"46 - essas são, justamente, as imposições sociais ao sexo feminino, transpostas à literatura. Assim, "O 'mundo exterior' responsável pela formação do herói do 'Bildungsroman' seria, no caso da protagonista feminina, os limites do lar e da família, não havendo margem para o seu crescimento interior" ${ }^{47}$.

Dessa forma, como alegou Virginia Woolf, a mulher escreveria exatamente as experiências pelas quais ela passava, e essa é uma das razões para o Bildungsroman feminino ser, ao menos até o século XX, apenas um "romance de aprendizagem" no qual a personagem se instruiria para ter uma "atitude estática, passiva"48 diante da vida, aprendendo que ela era destinada apenas a encontrar um bom marido e cuidar do lar. No entanto, outro fator analisado por Pinto é a interrupção do final das trajetórias dessas mulheres nos romances, que poderiam denunciar certa insubmissão da mulher ao que lhe era imposto: uma vez que "integração pessoal e integração social são incompatíveis para a protagonista do 'romance de aprendizagem' tradicional (...) inúmeras obras começam como 'Bildungsromane' potenciais mas terminam por não mostrar o pleno desenvolvimento da personagem". A isso a crítica deu o nome de "Bildungsroman truncado" ("truncated Bildungsroman") ou "Bildungsroman fracassado" ("failed Bildungsroman"). Dois desses finais são, por exemplo, o suicídio e a loucura, entendidos "como uma forma de punição da mulher que tentou ir além dos limites sociais normalmente aceitos"49, ao mesmo tempo que "um modo indireto, mudo, de protesto, uma rejeição da estrutura social que exige da mulher submissão e dependência" ${ }^{50}$. Mas há, também, possibilidade de um futuro otimista, como ainda analisa Pinto: "Quando o rompimento com as imposições sociais parece levar a personagem a um destino positivo, este não se define claramente, não chega a concretizar-se, mas fica sugerido o texto" ${ }^{51}$.

\footnotetext{
45 "The Bildungsroman is a male affair". MORGAN, Ellen. Humanbecoming: form and focus in the neofeminist novels APUD PINTO, Cristina Ferreira. O Bildungsroman feminino: quatro exemplos brasileiros. São Paulo: Perspectiva, 1990, p. 13.

${ }^{46}$ PINTO, 1990, p. 13.

${ }^{47}$ Ibidem.

${ }^{48}$ Ibidem, p. 14.

${ }^{49}$ Ibidem, p. 18.

${ }^{50}$ Ibidem, p. 17.

${ }^{51}$ Ibidem, p. 24.
} 
Tanto a morte e a alienação quanto a indefinição final da protagonista no que seria o Bildungsroman feminino parecem ser, como a procura do lápis pela personagem de Woolf, meras máscaras, que escondem a verdadeira ambição da mulher: emancipar-se socialmente. Enquanto isso lhe era negado, seriam também negadas as chances do sexo feminino em expandir sua escrita (afinal, como observou Woolf, a mulher - e o homem - escreve aquilo que é sua experiência) e, ainda, o pleno desenvolvimento feminino nas artes, que, novamente lembrando Woolf, precisaria de tempo, dinheiro e espaço próprio para realizarem-se plenamente. Portanto, impossível haver um pleno Bildungsroman feminino - por isso, como visto, eles seriam chamados até então de "romance de aprendizagem", em contraposição com o "romance de formação" ou "de educação", em termos traduzidos, que seriam as narrativas de personagens masculinas - e, consequentemente, o Künstlerroman de uma protagonista feminina enquanto a mulher fosse ainda subjugada ao ambiente doméstico - já que, como visto, este narraria a formação e a trajetória de um artista.

Contudo, no século XX, a ordem social parece, lentamente, entrar em mudança. Ao redor do mundo, discutia-se a possibilidade de a mulher alcançar o mercado de trabalho, estudar nas universidades, poder votar e poder ter sua propriedade, como debatido nos textos de Virginia Woolf e até de Clarice Lispector, já mostrados. É neste século que o "Bildungsroman truncado" parece ganhar força - inclusive os latino-americanos que, como nota Cristina Oliveira Pinto, "são obras escritas mais ou menos a partir de 1920". O primeiro romance de Lispector, Perto do coração selvagem, publicado em 1943, pode de alguma forma elucidar alguns desses pontos aqui explanados sobre o romance de formação feminino, a busca da mulher em se libertar das amarras sociais e o final "fracassado" da personagem feminina ante a dissolução de seu casamento, tendo seu destino inconcluso na obra. Por meio da protagonista Joana, é possível notar um processo de insubmissão da protagonista à vida socialmente imposta ao sexo feminino, procurando, a seu modo, transgredir o que lhe é instituído, almejando um novo futuro no qual ela seja capaz de decidir a trajetória de sua própria vida.

\subsection{Um exemplo clariceano}

O romance inaugural da autora conta a trajetória da personagem Joana, desde a infância até a vida adulta, sendo, portanto, considerada por muitos críticos, inclusive Cristina Oliveira Pinto, como um Bildungsroman. Em síntese, a história de Joana passa por uma infância solitária, uma adolescência marcada pela morte do pai e pelos cuidados da tia, um 
casamento "mal-sucedido" com Otávio - no qual ambos, marido e mulher, acabam se envolvendo em relações extraconjugais -, sua consequente separação e a viagem final, indefinida e misteriosa, da protagonista.

$\mathrm{Na}$ leitura do romance, nota-se que Joana demonstra, desde a infância, certas peculiaridades, que podem caracterizá-la possivelmente como uma transgressora, ou ao menos uma "estranha", parecendo não pertencer à ordem social: enquanto criança, a protagonista brincava sozinha, inventava histórias, escrevia poemas e os apresentava apenas ao pai - quando ele estava disposto a ouvi-la -, entediava-se rapidamente de suas brincadeiras solitárias e já via dificuldade em chamar a atenção das pessoas e de convidá-las para perto de si, dizendo que era "difícil aspirar as pessoas como o aspirador de pó" 52 - o que reafirma o caráter introvertido da personagem desde então, que via na fabulação solitária um modo de entreter-se:

- Papai, inventei uma poesia.

- Como é o nome?

- Eu e o sol. - Sem esperar muito recitou: - "As galinhas que estão no quintal já comeram duas minhocas mas eu não vi."

- Sim? Que é que você e o sol têm a ver com a poesia?

Ela olhou-o um segundo. Ele não compreendera...

- O sol está em cima das minhocas, papai, e eu fiz a poesia e não vi as minhocas... - Pausa. - Posso inventar outra agora mesmo: "Ó sol, vem brincar comigo." Outra maior:

"Vi uma nuvem pequena

coitada da minhoca

acho que ela não viu."

- Lindas, pequena, lindas. Como é que se faz uma poesia tão bonita?

- Não é difícil, é só ir dizendo. $(. . .)^{53}$

Já vestira a boneca, já a despira, imaginara-a indo a uma festa onde brilhava entre todas as outras filhas. Um carro azul atravessava o corpo de Arlete, matava-a. Depois vinha a fada e a filha vivia de novo. A filha, a fada, o carro azul não eram senão Joana, do contrário seria pau a brincadeira. Sempre arranjava um jeito de se colocar no papel principal exatamente quando os acontecimentos iluminavam uma ou outra figura. Trabalhava séria, calada, os braços ao longo do corpo. Não precisava aproximar-se de Arlete para brincar com ela. De longe mesmo possuía as coisas.

Divertiu-se com os papelões. Olhava-os um instante e cada papelão era um aluno. Joana era a professora. Um deles bom e outro mau. Sim, sim, e daí? E agora agora agora? E sempre nada vinha se ela... pronto.

Inventou um homenzinho do tamanho do fura-bolos, de calça comprida e laço de gravata. Ela usava-o no bolso da farda de colégio. O homenzinho era uma pérola de bom, uma pérola de gravata, tinha a voz grossa e dizia de dentro do bolso: "Majestade Joana, podeis me escutardes um minuto, só um minuto podereis interromperdes vossa sempre ocupação?" E declarava depois: "Sou vosso servo, princesa. É só mandar que eu faço." ${ }^{4}$

\footnotetext{
${ }^{52}$ LISPECTOR, Clarice. Perto do coração selvagem. Rio de Janeiro: Rocco, 1998, p. 14.

53 Ibidem, p. 14.

${ }^{54}$ Ibidem, p. 14-15.
} 
$\mathrm{Na}$ adolescência, morando com a tia após a morte do pai, Joana rouba, aparentemente sem culpa, um livro, o que causa a repugnância da mulher, que a caracteriza então como uma "víbora fria":

No momento em que a tia foi pagar a compra, Joana tirou o livro e meteu-o cuidadosamente entre os outros, embaixo do braço. A tia empalideceu.

$\mathrm{Na}$ rua a mulher buscou as palavras com cuidado:

- Joana... Joana, eu vi...

Joana lançou-lhe um olhar rápido. Continuou silenciosa.

_ Mas você não diz nada? - não se conteve a tia, a voz chorosa. - Meu Deus, mas o que vai ser de você?

- Não se assuste, tia.

- Mas uma menina ainda... Você sabe o que fez?

- Sei...

- Sabe... sabe a palavra...?

- Eu roubei o livro, não é isso?

- Mas, Deus me valha! Eu já nem sei o que faça, pois ela ainda confessa!

- A senhora me obrigou a confessar.

- Você acha que se pode... que se pode roubar?

- Bem... talvez não.

- Por que então...?

- Eu posso.

- Você?! - gritou a tia.

- Sim, roubei porque quis. Só roubarei quando quiser. Não faz mal nenhum.

- Deus me ajude, quando faz mal, Joana?

- Quando a gente rouba e tem medo. Eu não estou contente nem triste. $(. . .)^{55}$

essa menina [Joana]... (...) É uma víbora. É uma víbora fria, Alberto, nela não há amor nem gratidão. Inútil gostar dela, inútil fazer-lhe bem. Eu sinto que essa menina é capaz de matar uma pessoa... (...) É um bicho estranho, Alberto, sem amigos e sem Deus - que me perdoe! ${ }^{56}$

Na vida adulta, Joana repudia o casamento - mesmo depois cedendo a ele, casandose com Otávio - uma vez que esse tipo de relacionamento, segundo sua visão, tiraria sua liberdade e sua solidão:

Julgava mais ou menos isso: o casamento é o fim, depois de casar nada mais poderá me acontecer. Imagine: ter sempre uma pessoa ao lado, não conhecer a solidão. - Meu Deus! não estar consigo mesma nunca, nunca. E ser uma mulher casada, quer dizer, uma pessoa com destino traçado. Daí em diante é só esperar pela morte. Eu pensava: nem a liberdade de ser infeliz se conserva porque se arrasta consigo outra pessoa. Há alguém que sempre a observa, que a perscruta, que acompanha todos os seus movimentos. E mesmo o cansaço da vida tem certa beleza quando é suportado sozinha e desesperada - eu pensava. Mas a dois, comendo diariamente o mesmo pão sem sal, assistindo à própria derrota na derrota do outro...

\footnotetext{
${ }^{55}$ Ibidem, p. 49-50.

56 Ibidem, p. 51.
} 
Isso sem contar com o peso dos hábitos refletidos do outro, o peso do leito comum, da mesa comum, da vida comum, preparando e ameaçando a morte comum. Eu sempre dizia: nunca. ${ }^{57}$

Após se relacionar com um amante e conhecer também a amante de seu marido, Lídia, a qual obedecia às regras sociais do cuidado com a lar, com o marido e com a maternidade, Joana se separa de Otávio e parte em uma viagem desconhecida ao leitor. É justamente esse final aberto que pode caracterizar o romance como um "Bildungsroman truncado" - no caso, pode ter uma interpretação positiva, uma vez que, retomando Cristina Ferreira Pinto, a falta de clareza no desfecho da protagonista foge do destino da morte e da alienação comumente atribuídos àquelas que transgrediam as normas sociais, podendo sugerir um futuro esperançoso. De certa forma, as próprias últimas palavras de Joana podem ser interpretadas com certo otimismo: "e então nada impedirá meu caminho até a morte-sem-medo, de qualquer luta ou descanso me levantarei forte e bela como um cavalo novo" ${ }^{58}$.

Assim, a protagonista de Perto do coração selvagem parece se enquadrar na tendência de Bildungsroman feminino do século XX. Ainda, pode-se notar que Joana apresenta tendências artísticas, voltadas à arte literária: antes da vida adulta, como mostrado há pouco em trechos que descrevem sua infância e adolescência, ela escreve poemas, inventa histórias e rouba um livro - que parecia ser, para ela, um objeto de desejo. Futuramente, com o amante, Joana parece reencontrar-se: na companhia dele, a personagem mostra se sentir mais livre para continuar sua atividade da infância de fabular, inventar palavras, versos e reflexões:

- Conte aquilo... - disse-lhe o homem.

- O quê?

- Do marinheiro. Se amares um marinheiro terás amado o mundo inteiro.

- Horrível... - riu Joana. Eu sei: eu mesma disse que devia ser tão verdade que já nascia com rima. $(. . .)^{59}$

Ela contara-lhe certa vez que em pequena podia brincar uma tarde inteira com uma palavra. Ele pedia-lhe então para inventar novas. Nunca ela o queria tanto como nesses momentos.

- Diga de novo o que é Lalande - implorou a Joana.

- É como lágrimas de anjo. Sabe o que é lágrimas de anjo? Uma espécie de narcisinho, qualquer brisa inclina ele de um lado para outro. Lalande é também mar de madrugada, quando nenhum olhar ainda viu a praia, quando o sol não nasceu. Toda a vez que eu disser: Lalande, você deve sentir a viração fresca e salgada do mar, deve andar ao longo da praia ainda escurecida, devagar, nu. Em breve você sentirá Lalande... Pode crer em mim, eu sou uma das pessoas que mais conhecem o mar. ${ }^{60}$

\footnotetext{
57 Ibidem, p. 148-149.

58 Ibidem, p. 202, grifos meus.

${ }^{59}$ Ibidem, p. 167.

${ }^{60}$ Ibidem, p. 169-170.
} 
Regina Pontieri já notara que Joana era uma "artista em formação"61, e que tal romance "conta não só a errância de uma mulher ao longo de vários estágios de vida, mas também um aprendizado da escritura"62. Cristina Oliveira Pinto também destaca que, neste romance, "aparece o tema essencial em toda a obra de Lispector: a luta da personagem pela autoexpressão (...) uma luta para fugir ao domínio dessa Linguagem e construir a sua própria, criar uma linguagem através da qual ela possa expressar a sua essência e a realidade tal como ela a percebe" 63 .

Dessa forma, Joana parece demonstrar certas inclinações artísticas, voltadas à escrita. Se a sua luta for mesmo pela autoexpressão e pela criação de uma linguagem própria, que possa exprimir a si e a sua vida satisfatoriamente, uma interpretação pode, talvez, ser feita sobre seu destino: ela possivelmente buscará uma formação artística. Mesmo esse caminho final da personagem sendo nebuloso, é possível notar que a trajetória de Joana, além de ser um Bildungsroman (truncado), pode ser, também, um Künstlerroman - ou ao menos uma espécie de "esboço" de um Künstlerroman. Joana parece se enquadrar nas palavras de Marcuse: ela "não acha qualquer satisfação nas formas de vida do mundo que o cerca, com todas as suas limitações; sua autêntica personalidade e seus desejos não encontram ressonância ali; em solidão ele fica contra a realidade" ${ }^{64}$. A protagonista de fato parece viver em inconformidade com o que ditam as normas sociais - ao menos ela aparenta buscar viver à margem dessas regras: desde criança, parece prezar pela sua solidão e introspecção, o que a faz posteriormente detestar a ideia do casamento; ela rouba, mas, aparentemente, não sente culpa pelo ato; seu relacionamento com Otávio é marcado pela infidelidade de ambos os lados, o que leva à separação do casal; por fim, Joana, com o dinheiro que seu pai a deixara de herança (aqui, a protagonista não necessita do trabalho para alcançar independência financeira), embarca em uma viagem, com a companhia apenas de si mesma.

Apesar do final da trajetória de Joana ser misterioso, nos próximos romances clariceanos, como se mostrará a seguir, nota-se a continuidade de se retratar personagens artistas - duas das quais são mulheres: G.H. é uma escultora - inclusive, nesse romance, que é o foco desta pesquisa, nota-se justamente a introversão narrativa, conforme Fletcher e Bradbury caracterizaram: G.H. demonstra, de certa maneira, aos próprios mecanismos de

\footnotetext{
${ }^{61}$ PONTIERI, Regina. Clarice Lispector: uma poética do olhar. São Paulo: Ateliê Editorial, 2001, p. 169.

62 Ibidem, p. 105.

${ }^{63}$ Pinto, 1990, p. 84-85.

${ }^{64}$ MARCUSE, 2007, p. 78.
} 
construção da sua obra, como se verá adiante na análise; a narradora de Água viva, uma pintora; Rodrigo S.M., de A hora da estrela, e o Autor de Um sopro de vida são escritores; Ângela Pralini, uma aspirante a pintora. Além disso, diversos são os escritos ficcionais e nãoficcionais (como as entrevistas, que serão analisadas a seguir) em que o tema da arte e do artista se faz presente.

É comum na crítica clariceana encontrar autores que veem a obra de Lispector, sobretudo os romances, com uma visão de continuidade, como se uma nova narrativa fosse a sequência de uma obra anterior. Cristina Ferreira Pinto demonstra, a sua maneira, essa perspectiva de leitura, notando que o término de Perto do coração selvagem é, além do início da trajetória de Joana, também o início das obras posteriores de Clarice - ou, como se quer defender aqui, o final pode ser justamente o início da formação artística de Joana, bem como prenunciar a trajetória das personagens artistas clariceanas e do tema da arte em sua obra:

Perto do coração selvagem recomeça a trajetória de Joana, com a promessa de realização pessoal e satisfação dos seus anseios e expectativas. O caminho em direção à integração do EU, iniciado pela primeira protagonista de Clarice Lispector, vai ser seguido pelas personagens das obras seguintes. Estas vivem essencialmente os mesmos problemas e lutas de Joana, estabelecendo-se, assim, uma continuidade entre as diversas protagonistas. ${ }^{65}$

${ }^{65}$ PINTO, 1990, p. 107. 


\section{CLARICE LISPECTOR: ENTRE A ESCRITA E AS ARTES VISUAIS}

\subsection{Das entrevistas}

Entre 1968 e 1969, Clarice Lispector publicou, na revista Manchete, entrevistas com personalidades diversas do país. Esse período não foi o único em que ela entrevistou famosos para a mídia: entre 1976 e 1977, a escritora também publicou entrevistas na revista Fatos \& Fotos: Gente. Algumas dessas conversas foram reproduzidas nos livros Clarice Lispector: Entrevistas e Clarice na cabeceira: Jornalismo, ambos publicados pela editora Rocco em 2007 e 2012, respectivamente. Desses dois livros, destacam-se aqui algumas entrevistas que Clarice fez com artistas, com o objetivo de investigar e traçar seus interesses no mundo das diversas artes. ${ }^{66}$

Clarice, enquanto entrevistadora, tentava, de alguma forma, buscar respostas para suas próprias questões, ao invés de apenas fazer perguntas sobre os entrevistados exclusivamente - o que acontece na maioria das entrevistas, considerando o gênero em sua tradição. Assim, parece que Clarice, ao investigar o outro, procurava também investigar a si mesma. Essa urgência pelo autoconhecimento pode ser vista, por exemplo, quando a autora entrevista o escritor e psicanalista Hélio Pellegrino, fazendo-lhe uma pergunta (ou quase uma súplica) final: "Hélio, você é analista e me conhece. Diga - sem elogios - quem sou eu, já que você me disse quem é você. Eu preciso conhecer o homem e a mulher"67.

Ainda, como se verá melhor adiante, Clarice também colocava a si mesma e suas opiniões em muitas dessas conversas com artistas - seja ele escritor, pintor, escultor, músico ou cineasta; além disso, nota-se certa repetição de perguntas sobre os processos do fazer artístico dos entrevistados e sobre a razão que os guia em suas artes. Dessa forma, nota-se como a autora parecia de fato fazer uma espécie de pesquisa com esses entrevistados ${ }^{68}$.

\footnotetext{
${ }^{66}$ Cabe notar que as entrevistas ocorreram depois do lançamento de A paixão segundo G.H., em 1964. Ainda, as entrevistas feitas para a revista Manchete são anteriores à publicação de Água viva, em 1973 - romance no qual há, novamente, o diálogo com outras artes, a partir de uma narradora pintora. Ou seja: independente da data, é importante notar como era caro a Clarice a reflexão sobre a arte, seja dentro ou fora de sua ficção.

67 Entrevistado: Hélio Pellegrino. In: LISPECTOR, Clarice. Entrevistas. Org. Claire Williams e Teresa Montero. Rio de Janeiro: Rocco, 2007, p. 65.

${ }^{68}$ Importante ressaltar, aqui, o artigo de Lilian Hack intitulado "Clarice Lispector e as entrevistas com artistas: uma escuta da pintura" (Revista Valise, Porto Alegre, v. 7, n. 14, ano 7, dezembro de 2017), no qual Hack cria três categorias de perguntas de Clarice para seus entrevistados artistas: a Pergunta de Origem (sobre quando e como tal artista começou a trabalhar com sua arte), a Pergunta de Fuga (se o artista não seguisse aquela profissão, o que ele faria?) e a Pergunta de Quebra (aquelas em que Clarice demonstra interesse pela passagem
} 
Procurando, aparentemente, uma síntese comum sobre o fazer artístico que poderia explicar seus próprios questionamentos e anseios, Clarice sintetizava também o que se encontra vastamente em sua obra: a tentativa de compreensão do outro para uma possível compreensão de si mesma - "Fernando, por que é que você escreve? Eu não sei por que eu escrevo, de modo que o que você disser talvez sirva para mim."69; "O que é que você queria alcançar, Djanira? Eu também procuro alcançar alguma coisa que não sei o que é. Você sabe o que é?"70; "Fayga, eu às vezes tenho náusea da palavra escrita. Isto só sucede com a palavra escrita ou acontece também o mesmo ao artista plástico?"71; "Pra mim a arte é uma busca, você concorda?"72; "Para quem você faz música e para quem eu escrevo?"73.

Além de três questões que a própria escritora dizia ser fundamentais e que ela as repetia sempre que possível com seus entrevistados - Qual a coisa mais importante do mundo? Qual a coisa mais importante do mundo para a pessoa como indivíduo? O que é o amor? -, perguntas sobre inspiração, disciplina, processo criativo, vocação, talento e as razões do fazer artístico também são bem comuns em suas entrevistas, demonstrando a curiosidade de Clarice sobre os possíveis atributos que fazem de um sujeito um artista, além de seus próprios modos de ver a fazer sua arte. Alguns exemplos dão a ver a recorrência das questões em diversas entrevistas (e a reversibilidade entre entrevistadora e entrevistados):

Como é que começa em você a criação, por uma palavra, uma ideia? É sempre deliberado o seu ato criador? Ou você de repente se vê escrevendo? Comigo é uma mistura. É claro que tenho o ato deliberador, mas precedido por uma coisa qualquer que não é de modo algum deliberada. (...) Fernando, qual o seu processo de trabalho, você se inspira como? Ou se trata de uma disciplina? (...) Fernando, você tem medo antes e durante o ato criador? Eu tenho: acho-o grande demais para mim. E cada novo livro meu é tão hesitante e assustado como um primeiro livro. Talvez isso aconteça com você, e seja o que está atrapalhando a formação de seu novo romance. Estou ficando impaciente à espera de um romance seu. $(. . .)^{74}$

da figuração à abstração, como será explanado a seguir). Focando-se no diálogo das entrevistas de Clarice com suas pinturas, o objetivo da pesquisadora aproxima-se, de certa maneira, com o objetivo desta dissertação:

o que se pretende desde esse campo de imanência comum a Clarice Lispector e outros artistas, é levantar a hipótese de que pintar, como escrever, é um modo de se interrogar sobre questões que constituem um campo comum de investigação da criação, um comum aos processos que envolvem a criação, que não faz restrição em relação ao campo desde onde emergem, ou seja, um comum que faz vazar as classificações que separam e hierarquizam as artes, como a literatura e a pintura, por exemplo. (HACK, 2017, p. 76)

${ }^{69}$ Entrevistado: Fernando Sabino. Ibidem, p. 32.

${ }^{70}$ Entrevistada: Djanira. Ibidem, p. 201.

${ }^{71}$ Entrevistada: Fayga Ostrower. Ibidem, p. 179.

72 Entrevistada: Lygia Fagundes Telles. Ibidem, p. 14.

73 Entrevistado: Tom Jobim. Ibidem, p. 113.

${ }^{74}$ Entrevistado: Fernando Sabino. Ibidem, p. 32-35. 
Você planeja de início a história ou ela vai se fazendo aos poucos? Eu, por exemplo, acho que tenho um vago plano inconsciente que vai desabrochando à medida que trabalho. (...) ${ }^{75}$

Qual o seu modo de escrever? Você tem disciplina e horários certos? (...) Você acredita na inspiração ou na disciplina? (...) Você tem, antes de escrever, tudo já planejado? (... $)^{76}$

Marques Rebelo me disse uma vez que reescrever era mais simples que escrever. Quanto a mim, Gullar, eu discordo, pois minhas frases já vêm prontas. Em você, como se processa o ato criador? Você reescreve? (...) Gullar, vou lhe fazer uma pergunta muito difícil que eu mesma não saberia como responder. É o seguinte: como nasce, em você, o poema, a palavra escrita? $(\ldots)^{77}$

De que modo lhe vem a inspiração, Millôr? Você sente que vem do seu inconsciente? (.... ${ }^{78}$

CLARICE: Tenho a impressão de que você nasceu com a estrela na testa: tudo lhe correu fácil e natural como um riacho de roça. Estou certa se pensei que para você não é muito laborioso criar?

CHICO BUARQUE: E não é. Porque às vezes estou procurando criar alguma coisa e durmo pensando nisso, acordo pensando nisso - e nada. Em geral eu canso e desisto. No outro dia a coisa estoura e qualquer pessoa pensaria que era gratuita, nascida naquele momento. Mas essa explosão vem do trabalho anterior inconsciente e aparentemente negativo. E como é o seu trabalho?

CLARICE: Vem às vezes em nebulosa sem que eu possa concretizá-lo de algum modo. Também como você, passo dias ou até anos, meu Deus, esperando. E, quando chega, já vem em forma de inspiração. Eu só trabalho em forma de inspiração.

CHICO BUARQUE: Até aí eu entendo, Clarice. Mas a mim, quando a música ou a letra vêm, parece muito mais fácil de concretizar porque é uma coisa pequena. Tenho a impressão de que se me desse ideia de construir uma sinfonia ou um romance, a coisa ia se despedaçar antes de estar completa.

CLARICE: Mas Chico, aí é que entra o sofrimento do artista: despedaça-se tudo e a gente pensa que a inspiração que passou nunca mais há de vir.

CHICO BUARQUE: Se você tem um ideia para um romance, você sempre pode reduzi-lo a um conto?

CLARICE: Não é bem assim, mas, se eu falar mais, a entrevistada fica sendo eu. (... $)^{79}$

Você não acha que é dever seu o de fazer a música que sua alma pede? (...) Vou confessar a você, Tom, sem o menor vestígio de mentira: sinto que se eu tivesse tido coragem mesmo, eu já teria atravessado a minha porta, e sem medo de que me chamassem de louca. Porque existe uma nova linguagem, tanto a musical quanto a escrita, e nós dois seríamos os legítimos representantes das portas estreitas que nos pertencem. Em resumo e sem vaidade: estou simplesmente dizendo que nós dois temos uma vocação a cumprir. Como se processa em você a elaboração musical que termina em criação? Estou simplesmente misturando tudo, mas não é culpa minha, Tom, nem sua: é que esta entrevista foi se tornando meio psicodélica. (...) Como é que você sente que vai nascer uma canção? (...) Faz parte da minha profissão estar mesmo sempre sozinha, sem colaboradores ou intérpretes. Escute, Tom, todas as vezes

75 Entrevistado: Érico Veríssimo. Ibidem, p. 42.

76 Entrevistada: Nélida Piñon. Ibidem, p. 45-47.

${ }^{77}$ Entrevistado: Ferreira Gullar. Ibidem, p. 53.

78 Entrevistado: Millôr Fernandes. Ibidem, p. 58.

${ }^{79}$ Entrevistado: Chico Buarque. Ibidem, p. 99-100. 
em que eu acabei de escrever um livro ou um conto, pensei com desespero e com toda a certeza de que nunca mais escreveria nada. Você, que sensação tem quando acaba de dar à luz uma canção? (...)

DJANIRA: A gente pinta como quem ama, ninguém sabe por que ama, a gente não sabe por que pinta.

CLARICE: Eu também não sei por que escrevo.

DJANIRA: A gente não sabe. (...)

CLARICE: Quando é que você começou a pintar? (...)

DJANIRA: É muito curioso: por que será que a gente luta tanto para poder produzir uma obra de arte?

CLARICE: Acho, Djanira, que é para sobreviver.

DJANIRA: Mas para sobreviver naquilo que a gente quer. Uma criatura como eu, que sou autodidata em tudo, que tenho as minhas dificuldades e que toda a minha vida tem sido procurar superar a vida comum, na sociedade em que vivemos, procura um meio para alcançar aquilo que é uma profissão e uma vocação. Porque tudo o que se faz, o que eu faço, não basta. $(. . .)^{81}$

CLARICE: Iberê, por que é que você pinta? - perguntei-lhe de repente.

IBERÊ CAMARGO: Sabe que essa pergunta já me foi feita no questionário da Editora Vozes? Dei a seguinte resposta: só poderia responder por que é que pinto quando tiver descoberto o que eu sou como ser.

CLARICE: Essa resposta bem serviria para quando eu mesma me pergunto por que escrevo. Teria antes de ir ao profundo último de meu ser. (...) Qual o processo criador de um pintor versus o processo criador de um escritor em prosa ou poesia?

IBERÊ CAMARGO: Suponho, Clarice, que a diferença que existe esteja apenas na diferença de elementos. $O$ pintor usa a cor, a tinta, a linha. $O$ escritor usa a frase. Mas o impulso criador deve ser o mesmo. Que é que você acha? que é de uma natureza diversa?

CLARICE: Acho que a fonte é a mesma. Mas fiquei impressionada com Lúcio Cardoso que, depois da doença, não conseguia escrever nem ditar, pois não falava, mas pintava com a mão esquerda, já que a direita estava inutilizada: por que não escrevia com a mão esquerda? $\mathrm{O}$ médico explicou-me que no cérebro existe, se entendi bem, uma parte de onde sai a escritura, a palavra, e outra de onde sai a pintura. (...) Antes de começar a pintar um quadro você o visualiza já pronto ou vai passo a passo descobrindo o mundo particular desse quadro? (...) Até que ponto você se sente liberado depois que dá à luz um quadro? Pára por um tempo? ou a ânsia de criar se segue imediatamente?

Profunda reflexão de Iberê. Fico esperando. Até que ele diz: após a realização de um quadro, ou de uma série, segue-se um esvaziamento que por seu turno é substituído por uma gestação que se processa, e o período criador renasce então. Você tem a mesma experiência?

IBERE CAMARGO: Igual. Sinto um esvaziamento que quase se pode chamar sem exagero de desesperador. Mas para mim é pior: a germinação e a gestação para o novo trabalho podem demorar anos, anos esses em que feneço. $(. . .)^{82}$

A partir do olhar que persegue em A paixão segundo G.H. o viés da protagonista artista e as características do esculpir, cabe investigar mais de perto as entrevistas com

\footnotetext{
${ }^{80}$ Entrevistado: Tom Jobim. Ibidem, p. 113-116.

81 Entrevistada: Djanira. Ibidem, p. 199-201.

82 Entrevistado: Iberê Camargo. Ibidem, p. 209-212.
} 
escultores, traçando algumas relações entre a posição de Clarice enquanto entrevistadora de artistas e a sua atividade ficcional:

Maria, o que a levou à gravura? (...) A quem você deve o aprendizado da gravura? (... $)^{83}$

(...) você conseguiu esculpir, eu consegui escrever. Qual o nosso mútuo milagre? Acho, eu mesma, que conseguimos devido a uma vocação bastante forte e uma falta de medo de ser considerada "diferente" no ambiente social diplomático. Que é que você acha? (...) Como é que você descobriu que tinha talento para a escultura? $(. . .)^{84}$

Que é que faz de um homem um artista, Mário? (...) Como é que você descobriu em si mesmo o artista, e particularmente o escultor? (...) Que parte do seu "eu" você transmite em ligação com o mundo? $(\ldots)^{85}$

Como é que você descobriu que suas mãos eram tão valiosas? Na infância, brincando, ou mais tarde, conscientemente? (...) Quando fazem uma encomenda a você, como é que você se arranja para ter inspiração em fazer alguma coisa que não nasceu espontaneamente de você? (...) Em você, como se processa a inspiração? (...) E em você, como se processa a disciplina de trabalho? $(\ldots)^{86}$

Além desses muitos exemplos a respeito do questionamento do modo e das razões do fazer artístico de cada entrevistado, seja ele escultor ou pintor, outras perguntas e desabafos sobre o desgosto de Clarice pelo sucesso e sua falta de realização como escritora (que será um tema melhor explorado em suas crônicas, como se verá na próxima seção) também aparecem nesses materiais. No entanto, é importante averiguar as particularidades das entrevistas com escultores, uma vez que elas podem revelar alguns pontos interessantes e algumas curiosidades pertinentes da própria Clarice diante dos escultores e da atividade do esculpir, parecendo ela mesma refletir sobre a escultura nessas entrevistas, iniciando conversas sobre temas artísticos relevantes e complexos:

CLARICE: Você acha que a escultura é passível de didatismo, isto é, pode-se ensinar alguém a fazer escultura, numa fase inicial?

MÁRIO CRAVO: Só se o indivíduo tem potencializadas certas características fundamentais. Por exemplo, um homem que tem total aversão ao uso das mãos possivelmente estará menos aparelhado basicamente para se iniciar como escultor e, portanto, absorver a técnica. Há outras características que são do domínio das artes plásticas: perseverança, continuidade, intensidade etc. A escultura tem muito a ver com a ação fisica, embora esta seja, segundo meu modo de ver, resultante por sua vez de uma válvula sensorial e intelectual.

CLARICE: Como é que você descobriu em si mesmo o artista, e particularmente o escultor?

\footnotetext{
83 Entrevistada: Maria Bonomi. Ibidem, p. 173-174

84 Entrevistada: Maria Martins. Ibidem, p. 188.

85 Entrevistado: Mário Cravo. Ibidem, p. 191-193.

86 Entrevistado: Bruno Giorgi. Ibidem, p. 205-206.
} 
MÁRIO CRAVO: (...) Me senti escultor quando descobri um imenso amor pelos materiais e pelas formas. Tenho uma especial necessidade do contato com a matéria que será o instrumento de minha comunicação. Entre o escultor e a matéria tem que haver um diálogo, antes que o resultante venha a se transformar em mensagem. ${ }^{87}$

"Contato com a matéria" e "ação física": como se verá adiante com o romance que se deseja analisar, a protagonista de A paixão segundo G.H. levará essas características típicas do escultor a uma potência muito mais elevada. Ainda, pode-se notar o amor pelas formas também em G.H., como se verá melhor analisado adiante, tanto em sua profissão como escultora (já que essa é a arte que, essencialmente, transforma matéria bruta em forma artística) quanto em sua vida pessoal - através do que ela denomina como uma "terceira perna"88, um atributo dispensável que a mantinha resignada no seu mundo previamente conhecido e organizado, antes de sua experiência no quarto da empregada -; do trabalho distrativo com as bolinhas de pão na mesa do café da manhã, transformando-as em pequenas esculturas; e, também, das manias de organização diária, que a levam a estar sempre à procura de alguma forma para organizar a si mesma e ao mundo à sua volta e que a levaram à experiência narrada, surgida a partir da necessidade de arrumação do quarto da empregada recém-demitida - "não pertencesse eu por dinheiro e por cultura à classe a que pertenço, e teria normalmente tido o emprego de arrumadeira numa grande casa de ricos, onde há muito o que arrumar. Arrumar é achar a melhor forma"89. Entre a escultora G.H. e a matéria de sua arte visual e literária, houve de fato um diálogo antes da experiência ser passada pela mensagem do relato: G.H. escreve após o episódio ${ }^{90}$, pensando sobre ele, refletindo sobre suas consequências e, enfim, oferecendo ao leitor o seu aprendizado.

Além dessas características que Cravo cita sobre o caráter físico da escultura e de sua relação com o escultor - que, aliás, parecem ir ao encontro do que Clarice pensa sobre a arte:

\footnotetext{
${ }^{87}$ Ibidem, p. 192-193, meus grifos.

88 "Perdi alguma coisa que me era essencial, e que já não me é mais. Não me é necessária, assim como se eu tivesse perdido uma terceira perna que até então me impossibilitava de andar mas que fazia de mim um tripé estável. Essa terceira perna eu perdi. E voltei a ser uma pessoa que nunca fui. Voltei a ter o que nunca tive: apenas as duas pernas. Sei que somente com duas pernas é que posso caminhar. Mas a ausência inútil da terceira me faz falta e me assusta, era ela que fazia de mim uma coisa encontrável por mim mesma, e sem sequer precisar me procurar. Estou desorganizada porque perdi o que não precisava? (...) A idéia que eu fazia de pessoa vinha de minha terceira perna, daquela que me plantava no chão." LISPECTOR, Clarice. A paixão segundo G.H.. Rio de Janeiro: Rocco, 2009, p. 09-10, grifos meus. A partir daqui, todas as referências a esse romance aparecerão com seu nome abreviado: PSGH.

${ }^{89}$ PSGH, p. 32.

90 Esclarece G.H. na narrativa: "Ontem no entanto perdi durante horas e horas a minha montagem humana". PSGH, p. 11, grifos meus.
} 
ter contato íntimo com a matéria, preferindo "sempre trabalhar com as mãos"91 -, Clarice questiona frequentemente os artistas (tanto escultores - Mário Cravo, Maria Martins e Bruno Giorgi - quanto pintores - a exemplo, aqui, de Iberê Camargo) sobre suas fases figurativistas e abstracionistas. A escritora parece querer examinar uma espécie de diferenciação entre as duas tendências - talvez, no sentido de avaliar se esta diferenciação pode, de fato, ser feita, ou se a oposição não se sustenta e envolve questões mais complexas. Assim, ela própria insere a questão, direcionando-a aos artistas:

CLARICE: Você passou definitivamente da fase figurativista à abstracionista?

MÁRIO CRAVO: Eu sou um escultor figurativista mesmo quando faço coisas não figurativas. As minhas formas mais puras, mais despojadas, têm relação com o mundo orgânico. São núcleos, formas germinantes, óvulos ou ovulação, crescimento etc., todos eles termos essencialmente figurativos, embora não apresentados por forma humana ou animal. Estou preocupado em sintetizar estruturalmente, economicamente, o universo baiano, em princípio. ${ }^{92}$

CLARICE: Como você vê sua escultura, como figurativista ou abstracionista?

MARIA MARTINS: Eu sou antiismos. Dizem que sou surrealista. ${ }^{93}$

CLARICE: Nessa fase do mármore você sempre foi abstracionista ou também figurativista? BRUNO GIORGI: Exclusivamente abstracionista. Não porque eu tenha preconceitos contra o figurativo, é claro, mas uma forma abstrata em mármore, como estou realizando no momento, recebe a luz em plenitude. E a passagem entre as zonas de luz e as zonas de sombra é doce, e faz com que o mármore se apresente em toda a pujança e beleza.

CLARICE: E quanto à sua fase figurativista?

BRUNO GIORGI: Foi extraordinariamente importante e necessária. A figura criou em mim uma disciplina e me deu o sentido exato da proporção, da estruturação e da dinâmica, elementos imprescindíveis numa escultura. Sem esse preâmbulo figurativista, nunca teria alcançado seriamente a fase abstrata. ${ }^{94}$

CLARICE: Como se processa em você o abandono da figura, para tornar-se um não figurativo?

IBERE CAMARGO: Eu não abandonei a figura, apenas a transformei. ${ }^{95}$

Como se vê na maioria das respostas, cada qual a sua maneira, os artistas parecem negar a oposição entre abstracionismo e figurativismo: "Eu sou um escultor figurativista mesmo quando faço coisas não figurativas" (Mário Cravo); "Eu sou antiismos" (Maria

\footnotetext{
${ }^{91}$ Como será demonstrado depois, novamente, mas já antecipando aqui: "Se fosse eu, preferia sempre trabalhar com as mãos". LISPECTOR, 2007, p. 207 (Entrevistado: Bruno Giorgi).

92 Ibidem, p. 194.

93 Ibidem, p. 189.

${ }^{94}$ Ibidem, p. 204-205.

${ }^{95}$ Ibidem, p. 211.
} 
Martins); "Eu não abandonei a figura, apenas a transformei" (Iberê Camargo). Ainda que pareça haver certa aceitação dessa dicotomia, como há na resposta de Bruno Giorgi, não há uma depreciação de um dos dois conceitos em detrimento do outro, pelo contrário: pela sua resposta - "Sem esse preâmbulo figurativista, nunca teria alcançado seriamente a fase abstrata"-, nota-se que, aparentemente, o abstrato e o figurativo parecem ser ambas as faces de uma mesma moeda, existindo juntas, precisando experimentar uma para se chegar à outra.

Clarice demonstra certa preocupação com esse tema. Para além das entrevistas, há uma crônica - ou, talvez, seja possível chamá-la de aforismo - em que a autora manifesta uma visão semelhante a desses artistas: não há abstrato versus figurativo; na verdade, o abstrato é o figurativo:

\begin{abstract}
Abstrato é o figurativo
Tanto em pintura como em música e literatura, tantas vezes o que chamam de abstrato me parece apenas o figurativo de uma realidade mais delicada e mais difícil, menos visível a olho nu. ${ }^{96}$
\end{abstract}

Clarice acaba por revelar certa obsessão por esse tema. Talvez pelo próprio fato de a enquadrarem sempre como mais próxima do abstrato, caracterizando-a frequentemente como hermética (como ela aponta, inclusive, em entrevista a Júlio Lerner, discordando do adjetivo atribuído à sua escrita: "Eu me compreendo. De modo que eu não sou hermética pra mim"97). Possivelmente essa crônica seja mesmo uma forma de explicar sua literatura: perscrutando uma realidade quase invisível a olho nu, praticamente microscópica, mais delicada e mais difícil de se alcançar, buscando-a através de seus personagens, que percorrem narrativas à procura do it, do neutro, da intenção de tocar a própria coisa, do chegar à pureza do "invisível núcleo da realidade" 98 . Os desdobramentos da dialética figurativo versus abstrato retornarão nas crônicas, como se verá.

Para além da questão estética e dos temas relacionados ao fazer artístico e suas fases, percorrendo a leitura das entrevistas, nota-se que Clarice parece também investigar as condições de produção da escultura no Brasil, como quando questiona a Mario Cravo:

CLARICE: Você vende bem?

MÁRIO CRAVO: Razoavelmente bem para um escultor brasileiro que nasceu, vive e trabalha em Salvador.

\footnotetext{
${ }^{96}$ LISPECTOR, Clarice. In: A descoberta do mundo. Rio de Janeiro: Rocco, 1999, p. 316.

${ }^{97}$ Disponível em: https://www.youtube.com/watch?v=ohHP112EVnU.

${ }^{98}$ Lispector, Clarice. Água viva. Rio de Janeiro: Rocco, 1998, p. 22.
} 
CLARICE: Para sustento da vida, pode-se no Brasil viver apenas de arte, da escultura, por exemplo?

MÁRIO CRAVO: Eu vivo exclusivamente da arte. ${ }^{99}$

Nesse âmbito, talvez contribua para a discussão uma crônica de Manuel Bandeira, intitulada "O escultor":

$\mathrm{O}$ artista parou de modelar, deu um suspiro e, batendo várias vezes com o desbastador na prancheta, naquele gesto que lembra tanto o dos pássaros quando limpam o bico no pau do poleiro, repetiu tristemente a frase que ouvira, um dia, do grande Bourdelle:

- Quel malheur d'être sculpteur!

Desabafou. As razões dele não eram as de Bourdelle. Ou por outra, eram as de Bourdelle mais as dificuldades que os artistas plásticos encontram no Brasil para criar a sua obra. Um poeta precisa apenas de lápis e uma folha de papel (que pode ser até de embrulho) para escrever o poema; já o escultor necessita de tanta coisa cara! E o problema do modelo? Era precisamente o problema do modelo que fazia o meu amigo suspirar tão fundo no momento em que falou como Bourdelle. ${ }^{100}$

Bandeira destaca o aspecto caro da escultura (e das artes plásticas no geral) no Brasil, enquanto contrasta essa arte com a simplicidade de materiais do escritor - que precisaria apenas de lápis e papel, podendo, esse, ser inclusive de embrulho, algum material reaproveitado; por isso, a escultura não teria tanto destaque no país. A reflexão sobre as dificuldades financeiras da produção da escultura no país remete à condição da protagonista G.H., que se mostra como uma mulher a qual, no âmbito financeiro, poderia de fato fazer escultura (e possivelmente viver dela, como Mário Cravo): como se verá, essa personagem já possui seu próprio apartamento - luxuoso, na cobertura de um prédio -, e não apresenta ter outro trabalho a não ser esculpir. G.H. mostra que vive mais sofisticadamente, não apenas procurando ter "um sustento de vida". Apesar de não se conhecer o passado financeiro da personagem e como ela conquistou todo esse aparato, nota-se como seu estilo de vida no presente momento da narrativa vai além do mero sustento necessário: "É bem mais que uma elegância"101. Portanto, G.H. demonstra ter a capacidade financeira de comprar toda essa "tanta coisa cara" que Bandeira caracteriza como sendo o material da arte escultórica.

Ainda conduzindo as entrevistas com breves comparações à A paixão segundo G.H., nota-se que elas podem auxiliar a aproximação entre as diferentes técnicas do desenho e da

\footnotetext{
${ }^{99}$ Entrevistado: Mário Cravo. LISPECTOR, 2007, p. 195.

100 BANDEIRA, Manuel. "O escultor". In: Poesia completa e prosa - volume único. Org. André Seffrin. Rio de Janeiro: Editora Nova Aguilar, 2009, p. 832.

${ }^{101}$ PSGH, p. 29.
} 
escultura. Chama a atenção que Clarice pergunte sobre desenho a escultores - duas artes que também se encontram no romance em questão, a partir de Janair e G.H., respectivamente -:

CLARICE: Sua pintura - disse-lhe eu - lembra-me a pintura que um escultor faria. A senhora já esculpiu?

FLORA MORGAN SNELL: Minha pintura é considerada pintura de escultor. ${ }^{102}$

CLARICE: Você desenha também? Porque sempre achei que o traço de um escultor é identificável por uma extrema simplicidade de linhas.

BRUNO GIORGI: Exatamente. Sempre me preocupei com o desenho e nada realizei sem severo estudo prévio de desenho. ${ }^{103}$

A simplicidade de linhas que caracterizaria, segundo Clarice, a pintura ou o desenho de um escultor pode ser encontrada, de certa forma, no próprio desenho de Janair na parede de G.H. - aproximado dos desenhos rupestres, que são justamente marcados pela simplicidade das formas e dos traçados. Parece ser possível, então, aproximar, de algum modo, o desenho de Janair da arte de G.H., como será melhor explanado no decorrer da análise do romance.

Por fim, é interessante também notar o comentário de Clarice após sua entrevista com Mário Cravo: "Todas as esculturas que vi no ateliê de Mário Cravo, eu as compraria, se pudesse. E nelas descobri realmente formas germinantes, óvulos, ovulação: vida, enfim."104 A barata vista por G.H., que se tornará uma espécie de "escultura verbal" da personagem, germina após a tentativa da protagonista de matá-la, esmagando-a na porta do guarda-roupa; e a consequente erupção de sua massa branca, o "de-dentro", exterioriza radicalmente sua vívida ovulação (utilizando os termos clariceanos). Essas formas plásticas, representadas de maneira tridimensional na escultura, em oposição à bidimensionalidade da pintura e do desenho, ao serem usadas por Clarice Lispector a fim de retratar as angústias da escultora narradora G.H., parecem representar a própria vontade da autora de, porventura, ter realizado um tipo de arte mais tátil e com maior contato com a matéria representada:

CLARICE: Se fosse eu, preferia trabalhar sempre com as mãos. material. $^{105}$

BRUNO GIORGI: Melhor seria, porque se transmite assim maior sensibilidade ao

\footnotetext{
102 Entrevistada: Flora Morgan Snell. In: LISPECTOR, Clarice. Clarice na cabeceira - jornalismo. Org. Aparecida Maria Nunes. Rio de Janeiro: Rocco, 2012, p. 233.

${ }^{103}$ Entrevistado: Bruno Giorgi. In: LISPECTOR, 2007, p. 205.

${ }^{104}$ Entrevistado: Mário Cravo. Ibidem, p. 196.

${ }^{105}$ Entrevistado: Bruno Giorgi. Ibidem, p. 207.
} 


\subsection{Das crônicas}

\section{Temas que morrem}

Sinto em mim que há tantas coisas sobre o que escrever. Por que não? O que me impede? A exiguidade do tema talvez, que faria com que este se esgotasse em uma palavra, em uma linha. Às vezes é o horror de tocar numa palavra que desencadearia milhares de outras, não desejadas, estas. No entanto, o impulso de escrever. O impulso puro - mesmo sem tema. Como se eu tivesse a tela, os pincéis e as cores - e me faltasse o grito de libertação, ou a mudez essencial que é necessária para que se digam certas coisas. Às vezes a minha mudez faz com que eu procure pessoas que, sem elas saberem, me darão a palavra-chave. Mas quem? quem me obriga a escrever? O mistério é esse: ninguém, e no entanto a força me impelindo. (...)

A verdade é que simplesmente me faltou o dom para a minha verdadeira vocação: a de

desenhar. Porque eu poderia, sem finalidade nenhuma, desenhar e pintar um grupo de formigas andando ou paradas - e sentir-me inteiramente realizada nesse trabalho. Ou desenharia linhas e linhas, uma cruzando a outra, e me sentiria toda concreta nessas linhas que os outros talvez chamassem de abstratas. (...)

Eu falaria sobre frutas e frutos. Mas como quem pintasse com palavras. Aliás, verdadeiramente, escrever não é quase sempre pintar com palavras? ${ }^{106}$

Em "Temas que morrem", Clarice aponta alguns temas que ela frequentemente trata não só em suas crônicas, mas em outros momentos de sua carreira literária - como nas entrevistas, já demonstradas. Primeiramente, logo no início do texto, o impulso da escrita em comparação com a arte que ela de fato gostaria de fazer, aquela em que se usa "tela, pincéis e cores", confronto que aparece também no último parágrafo retratado aqui: "escrever não é quase sempre pintar com palavras?"; logo no segundo parágrafo, a elucidação da sua verdadeira vocação: o desenho (e a pintura), a arte essencialmente visual em contraposição com a arte da palavra; e, finalmente, a questão da abstração, em uma possível contraposição e, ao mesmo tempo, identificação com o figurativo.

De fato, Clarice pintou alguns quadros - que foram analisados por Carlos Mendes de Sousa em um de seus livros sobre a autora ${ }^{107}$. No entanto, a própria escritora reconhecia em si uma "falta de dom" (usando os termos do conto anterior) para essa atividade artística, uma menor habilidade com as artes plásticas, que seriam sua vocação e que, se ela pudesse, teria escolhido para ser sua forma de manifestação:

\footnotetext{
${ }^{106}$ LISPECTOR, Clarice. "Temas que morrem". In: A descoberta do mundo. Rio de Janeiro: Rocco, 1999, p. 196-198. Esse "pintar com palavras" aproxima-se do ut pictura poesis de Horácio, o qual Lessing, em Laocoonte ou Sobre as fronteiras da pintura e da poesia, contraria, defendendo uma divisão clara entre poesia e pintura. Na modernidade, como estuda Joseph Frank no texto "A forma espacial na literatura moderna", a literatura se aproximará, de alguma forma, da espacialidade própria das artes visuais. Esse tópico se desenvolverá adiante, no decorrer do estudo de A paixão segundo G.H..

${ }^{107}$ SOUSA, Carlos Mendes de. Clarice Lispector: Pinturas. Rio de Janeiro: Rocco, 2013.
} 
Ao escrevê-lo, de novo a certeza só aparentemente paradoxal de que o que atrapalha ao escrever é ter de usar palavras. É incômodo. É como se eu quisesse uma comunicação mais direta, uma compreensão muda como acontece às vezes entre pessoas. Se eu pudesse escrever por intermédio de desenhar na madeira ou de alisar uma cabeça de menino ou de passear pelo campo, jamais teria entrado pelo caminho da palavra. Faria o que tanta gente que não escreve faz, e exatamente com a mesma alegria e o mesmo tormento de quem escreve, e com as mesmas profundas decepções inconsoláveis: viveria, não usaria palavras. O que pode vir a ser a minha solução. Se for, bem-vinda. ${ }^{108}$

Ainda:

O contato com o outro ser através da palavra escrita é uma glória. Se me fosse tirada a palavra pela qual tanto luto, eu teria que dançar ou pintar. Alguma forma de comunicação com o mundo eu daria um jeito de ter. E escrever é um divinizador do ser humano. ${ }^{109}$

A pintura e o desenho seriam, então, as suas formas artísticas mais desejadas, mas que não a haviam chamado. Por isso sua preferência, se fosse possível, de trabalhar sempre com as mãos, o que ocorreria, em certa medida, com a materialidade dos instrumentos próprios às artes visuais. No entanto, ela entendia que sua verdadeira vocação era, de fato, escrever - foi essa atividade, portanto, que a clamou: "Escrever sempre me foi difícil, embora tivesse partido do que se chama vocação. Vocação é diferente de talento. Pode-se ter vocação e não ter talento, isto é, pode-se ser chamado e não saber como ir" ${ }^{110}$. A vocação sem talento, sem saber para onde ir, pode ser justamente a definição de seu anseio pela pintura, explicando a razão de Clarice em não ter seguido no campo dessas artes visuais; enquanto que, para a escrita, a autora teria essas duas características fundamentais juntas e, portanto, ela obedeceu ao chamado da arte da palavra.

Apesar de serem seus o dom, a vocação e o talento, permitindo enfim que ela se lançasse na arte literária, a escrita se mostra para Clarice de forma paradoxal: é uma maldição ao mesmo tempo em que é uma salvação -

Eu disse uma vez que escrever é uma maldição. Não me lembro por que exatamente eu o disse, e com sinceridade. Hoje repito: é uma maldição, mas uma maldição que salva.

Não estou me referindo muito a escrever para jornal. Mas escrever aquilo que eventualmente pode se transformar num conto ou num romance. É uma maldição porque

\footnotetext{
${ }^{108}$ LISPECTOR, Clarice. "Lembrança da feitura de um romance". In: A descoberta do mundo. Rio de Janeiro: Rocco, 1999, p. 285-286, grifos meus.

${ }^{109}$ LISPECTOR, Clarice. "Adeus, vou-me embora!". In: A descoberta do mundo. Rio de Janeiro: Rocco, 1999, p. 96, grifos meus.

${ }^{110}$ LISPECTOR, Clarice. "Escrever". Ibidem, p. 286.
} 
obriga e arrasta como um vício penoso do qual é quase impossível se livrar, pois nada o substitui. E é uma salvação.

Salva a alma presa, salva a pessoa que se sente inútil, salva o dia que se vive e que nunca se entende a menos que se escreva. Escrever é procurar entender, é procurar reproduzir o irreproduzível, é sentir até o último fim o sentimento que permaneceria apenas vago e sufocador. Escrever é também abençoar uma vida que não foi abençoada.

Que pena que só sei escrever quando espontaneamente a "coisa" vem. Fico assim à mercê do tempo. E, entre um verdadeiro escrever e outro, podem-se passar anos.

Lembro-me agora com saudade da dor de escrever livros. ${ }^{111}$

De certa forma, essa "maldição que salva" pode caracterizar, também, o processo de G.H. em sua narrativa: ao fingir que está escrevendo para alguém, escapando, assim, de sua arte original (a escultura) e partindo para a arte verbal, G.H. procura se salvar, salvar "o dia que se vive e que nunca se entende ao menos que se escreva", pois "escrever é procurar entender, é procurar reproduzir o irreproduzível". E é isso que G.H. diz procurar fazer: compreender, pela escrita, pelo seu depoimento narrativo, o dia em que decidira limpar o quarto da empregada, recém-demitida, e que encontrara a pintura na parede deixada por ela e a barata no guarda-roupa, tentando reproduzir, por meio das palavras, sua experiência, que parecia a ela, até então, irreproduzível.

Diversas outras crônicas da autora trarão ainda o tema da escrita e/ou das artes visuais, principalmente da pintura. No entanto, focando, finalmente, a escultura, notam-se dois textos desse gênero que chamam a atenção: "Uma lição de escultura" e "Uma porta abstrata". O primeiro traz uma espécie de reelaboração da entrevista que Clarice fez com Mário Cravo, cujos temas já foram apontados anteriormente. O segundo, por sua vez, é uma pequena reflexão sobre o fazer literário, comparando-o com o esculpir. Segue a crônica na íntegra:

\section{Uma porta abstrata}

Sob certo ponto de vista, considero fazer coisas abstratas como o menos literário. Certas páginas, vazias de acontecimentos, me dão a sensação de estar tocando na própria coisa, e é a maior sinceridade. É como se eu esculpisse - qual é a mais verdadeira escultura de um corpo? o corpo, a forma do corpo, a expressão da própria forma corpo - e não a expressão "dada" ao corpo. Uma Vênus nua, em pé, "inexpressiva", é muito mais do que uma ideia literária de Vênus. Estou chamando "ideia literária de Vênus", uma Vênus, por exemplo, que tivesse no rosto um sorriso de Vênus, um olhar de Vênus, como um título. A Vênus de Milo - é uma mulher abstrata. (Se eu desenhar num papel, minuciosamente, uma porta, e se eu não lhe acrescentar nada meu, estarei desenhando muito objetivamente uma porta abstrata. $)^{112}$

\footnotetext{
${ }^{111}$ Ibidem, p. 134.

112 LISPECTOR, Clarice. "Uma porta abstrata". In: Todas as crônicas. Rio de Janeiro: Rocco, 2018, p. 657.
} 
Novamente, a ideia do abstrato e do figurativo se encontram nessa crônica: "Tanto em pintura como em música e literatura, tantas vezes o que chamam de abstrato me parece apenas o figurativo de uma realidade mais delicada e mais difícil, menos visível a olho nu."113 Consoante a essa ideia, a sensação de "tocar na própria coisa", para Clarice, era possível graças ao abstrato, essa outra faceta do figurativo, alcançando, assim, essa "realidade mais delicada e mais difícil, menos visível a olho nu". E a arte da escultura, usada como comparativo aos momentos em que a autora consegue chegar à própria coisa, é essa em que parece se tocar efetivamente o objeto a ser construído, trabalhando, da forma mais profunda, com as mãos - e, assim "transmitindo maior sensibilidade ao material", como refletiu Bruno Giorgi. Dessa forma, nos momentos em que Clarice não está de fato escrevendo apenas acontecimentos, mas tentando alcançar a coisa - ou o neutro, como em G.H., o it, em Água viva, dentre outros possíveis nomes -, ela está, de alguma forma, mais próxima da arte do esculpir (ou, ao menos, mais próxima do "tocar a própria coisa").

No entanto, como sua obra não cansa de repetir, o "tocar a coisa" na arte é impossível: o que se toca é a imagem dela. G.H. toca, ao escrever, o reflexo da barata, a exterioridade de seu neutro, e não a barata em si; toca a forma artística dada por ela, na narrativa, à barata. Mas não há como reproduzir sua experiência por inteiro, que não é só reflexo: ela de fato come da barata, e a literatura irá justamente refazer essa experiência; ou seja, o relato já é mimese, reflexão, mediação, mas não o ato. Mesmo no mais próximo de se tocar a coisa, portanto, comendo uma parte dela (mas depois expelindo-a, já que G.H. cospe a massa branca que tenta ingerir da barata), não há como se chegar a ela artisticamente - por isso, a busca incansável no início da narrativa sobre qual seria a forma ideal para contar o ocorrido, transformando-o em literatura. Sua busca é inconcebível, daí a frustração clariceana - para quem poderiam ecoar as palavras de Schiller: "quando a alma fala, já não fala a alma"114. Quando se toca a imagem da coisa, não é a coisa em si que se está tocando - uma vez que a linguagem (e em um nível mais mediado ainda, a arte da palavra) é sempre representação.

Além disso, pode-se destacar, em "Uma porta abstrata", como Clarice parece repensar os termos "representação" e "expressão" - outro tópico que também aparece na narrativa de G.H., como será mostrado. A "expressão da própria forma do corpo" seria o corpo em si, sem ser representado (mas, talvez, sendo quase que apresentado em sua materialidade). Já a

\footnotetext{
113 LISPECTOR, Clarice. "Abstrato é o figurativo". In: A descoberta do mundo. Rio de Janeiro: Rocco, 1999, p. 316.

114 apud ROSENFELD, Anatol. "Reflexões sobre o romance moderno". In: Texto/Contexto I. São Paulo: Editora Perspectiva, 1996, p. 73.
} 
"expressão 'dada' ao corpo" poderia ser pensada como a expressão artística - que, conforme Alfredo Bosi, seria a união entre força e forma, entre o "existir sensível" do homem e a forma que ele dá a esse ato $^{115}$-, a representação, podendo ser mimética ou não. Mas, como visto, Clarice não quer representar: seu desejo é o de ir à coisa, tocá-la inclusive artisticamente - o que é impossível. A escultura, segundo a crônica, daria essa impressão (possivelmente falsa) de se alcançar tal desejo. O que a autora parece buscar é um rompimento com a noção confortável de representação, uma espécie de nudez artística, momento em que se poderia tocar a coisa na arte, que não é o mesmo que representá-la mimeticamente. O que ela quer é alcançar o inalcançável: chegar ao it inclusive pela arte. Ela, inevitavelmente, representará a coisa almejada, mas essa não é exatamente a sua aspiração. O mesmo tipo de discussão se apresenta em A paixão segundo G.H.: que forma dar ao ocorrido, inaudito? Como transformar em arte a sua paixão, a sua trajetória de busca pelo núcleo da vida, pelo tocar na própria coisa?

Logo, todas essas narrativas - as crônicas, os contos o romance em questão - podem manifestar uma tentativa impraticável do artista em alcançar, de fato, na arte, o âmago do mundo. Apesar dessa impossibilidade, nota-se como o artista se apresenta como o sujeito que estaria mais disposto a "tocar na própria coisa".

Clarice, em sua crônica "O artista perfeito", sugere um pouco dessa ideia: partindo da concepção de Bergson sobre o "grande artista", o qual "seria aquele que tivesse, não só um, mas todos os sentidos libertos do utilitarismo"116, a autora reflete, então, como o sujeito "que estivesse completamente livre de soluções convencionais e utilitárias veria o mundo, ou melhor, teria o mundo de um modo como jamais artista nenhum o teve. Quer dizer, totalmente e na sua verdadeira realidade."117 Portanto, o homem que conseguisse ver a sinceridade do mundo seria alguém que conseguiria tornar "seus sentidos e alertas puros"118, de fato libertos do utilitarismo; tornaria-se, enfim, um inocente. Daí a questão principal de Clarice: se educássemos uma criança, libertando-a da visão utilitarista do mundo, com o intuito dela ser e permanecer inocente, ela não se tornaria uma artista, uma vez que a arte não é a inocência por si só, mas o ato de purificar-se e libertar-se do utilitarismo, experimentando

\footnotetext{
115 BOSI, Alfredo. Reflexões sobre a arte. São Paulo: Ática, 1986, p. 56.

${ }^{116}$ LISPECTOR, Clarice. "O artista perfeito". In: A descoberta do mundo. Rio de Janeiro: Rocco, 1999, p. 228.

${ }^{117}$ Ibidem, grifos meus.

${ }^{118}$ Ibidem.
} 
enfim essa verdadeira realidade e expressando, em sua arte, a "maravilhosa gratuidade" das coisas do mundo.

Assim, a questão de se tocar a própria coisa sem representá-la pode, também, ser pensada em outros termos: de captar a vida, a essência do mundo, sem a mediação da cultura, do simulacro. De modo que não representar os dados da realidade, tentando (mesmo que ilusoriamente) tocar o it na arte, pode ser pensado em termos de alcançar uma espécie de inocência, libertando-se do utilitarismo, purificando-se, como está captado na crônica. Logo, o que Clarice parece desenvolver, em "O artista perfeito", é a ideia de inocência como ato estético $^{119}$ :

(...) Clarice discute a questão da criação artística como fuga da utilidade por intermédio da sugestão fantasiosa de um sujeito formado por uma recusa absoluta aos padrões de conduta mundanos. $\mathrm{O}$ artista deveria ou poderia ser aquele que foge à convenção, à regra: apreende a "verdadeira realidade" dada sua indisposição em face da convenção e sua predisposição à liberdade. Até esse ponto, uma definição reconhecível: o artista - e consequentemente a arte - assume atitude de antítese em face do mundo. No entanto, o argumento adquire nuances a partir da hipótese mobilizada, segundo a qual a existência de um processo formativo, desvinculado dos padrões reinantes, conduziria uma criança à liberdade total, a ponto desta não se acostumar, não se adequar. Ao comentar a necessária fuga do utilitarismo rumo à inocência para a criação artística, a autora diferencia tal empreitada quando feita por um homem comum e por um artista; este não pode prescindir do conhecimento dos males do mundo. Imbuído dessa problemática, empreenderia um retorno à inocência como libertação. (...)

A etimologia ensina que "inocente" vem de innocens, aquele que não causa danos e não tem culpas. A arte, ao contrário, implica a aguda consciência do mal. O desajuste conduz ao paradoxo: a inocência almejada é conscientemente inocente, trata-se, pois, de uma construção estética nada inocente da inocência. Artifício refinado de pureza. ${ }^{120}$

Então, segundo Clarice, como a ideia de ir à coisa se articula com a concepção de inocência como caráter estético, o artista perfeito seria justamente aquele que estaria em oposição ao mundo, após conhecer "a aguda consciência do mal", escolhendo, por fim, a inocência de forma "nada inocente"121. Contraditoriamente, a busca da "coisa" seria, de certa forma, a busca da inocência, a partir do conhecimento do outro; mas, sendo essa busca através da arte, ela é impossível, uma vez que o artista por si só já não é inocente: está imbuído do mal do mundo. Esse é um segundo motivo da impossibilidade de se tocar a coisa artisticamente: buscando a inocência a partir do outro que a barata constitui, tocando, no

\footnotetext{
${ }^{119}$ C.f.: RUFINONI, Simone. "'O artista perfeito': Clarice Lispector e a poética da inocência". Revista Remate de Males. Campinas - SP: vol. 36, n.2, jul./dez. 2016, p. 357-379.

${ }^{120}$ Ibidem, p. 359-360.

${ }^{121}$ Ibidem.
} 
relato, o seu reflexo em sua massa branca e fazendo disso sua arte, a inocência do artista se prova inalcançável.

Viver o mal do mundo pode ser simbolizado, em A paixão segundo G.H., pela ingestão da barata: além desse gesto poder representar a tentativa mais pura de tocar o núcleo, ele também é uma forma de pecado, de acordo com a ordem judaico-cristã de não provar do impuro. Assim, G.H. estaria experimentando o maligno, o que pode ser a ideia de arte: vivenciar o perverso, o inapropriado, divergindo, assim, do resto do corpo social, como desenvolveu Herbert Marcuse. A busca pelo âmago do mundo e, consequentemente, pela inocência, aproximando-se da crônica "O artista perfeito", não é inocente; pelo contrário: ela passa pela experimentação danosa da realidade.

Após essa experiência pecaminosa, G.H. não será a mesma mulher que era antes de decidir entrar no quarto da empregada: parece que há, nesse romance, também uma narrativa de formação do artista, uma vez que a escultora estará, enfim, consciente de sua visão de si mesma e do mundo que a rodeia, libertando-se dos símbolos utilitários que antes a prendiam como simplesmente uma escultora amadora de uma classe alta do Rio de Janeiro; podendo, assim, desenvolver-se como artista efetivamente dita, incongruente à sociedade. ${ }^{122}$

\subsection{Dos romances e contos}

Nota-se, portanto, que o tema da arte e do artista perpassa a obra de Lispector tanto nas crônicas quanto nas entrevistas que ela faz com diversos artistas. Esse tema, contudo, não se restringe às crônicas e entrevistas, mas está sobretudo presente na sua obra ficcional: os contos e os romances.

Apontando, primeiramente os romances, é possível pontuar aqueles em que o próprio fazer literário será, de certa forma, tema da narrativa, como é o caso de $A$ hora da estrela, cujo protagonista que narra a história é o escritor Rodrigo S.M., e Um sopro de vida, no qual se apresenta um Autor não nomeado. Além desses, Joana, de Perto do coração selvagem, também pode ser considerada uma escritora - ou ao menos uma mulher inclinada à arte da palavra, como notou Regina Pontieri: Joana seria uma "artista em formação" (PONTIERI, 2001, p. 169) em uma obra que "conta não só a errância de uma mulher ao longo de vários estágios de vida, mas também um aprendizado da escritura" (PONTIERI, 2001, p. 105).

\footnotetext{
${ }^{122}$ Usando termos de Herbert Marcuse sobre o artista e o Künstlerroman.
} 
Ainda, é interessante observar como a arte da palavra aparece associada à infância e à adolescência em alguns contos da autora, como "Os desastres de Sofia", "Felicidade clandestina" e "A mensagem" - em todos esses, a criança e o adolescente aparecem, de certa maneira, como desejosos e detentores desse tipo de arte, seja apenas pela leitura ("Felicidade clandestina") quanto pela escrita em si (sendo ela já desenvolvida, como em "Os desastres de Sofia" ou constituindo uma forte ambição de experimentá-la, como em "A mensagem").

Em outros contos, nota-se o incipiente - apesar de irrealizável pelos protagonistas desejo de ser artista, como, por exemplo, o conto "Amor". O narrador conta como Ana cortava as cortinas, costurava as roupas dos meninos, decorava a casa, e como essas atividades artesanais eram uma espécie de ímpeto artístico silenciado pela vida imposta à mulher:

Todo o seu desejo vagamente artístico encaminhara-se há muito no sentido de tornar os dias realizados e belos; com o tempo seu gosto pelo decorativo se desenvolvera e suplantara a íntima desordem. Parecia ter descoberto que tudo era passível de aperfeiçoamento, a cada coisa se emprestaria uma aparência harmoniosa; a vida podia ser feita pela mão do homem. (...) Por caminhos tortos, viera a cair num destino de mulher, com a surpresa de nele caber como se o tivesse inventado. ${ }^{123}$

A atividade decorativa do lar faz com que Ana se assente na vida feminina como manda a sociedade. O "seu desejo vagamente artístico" de outrora fora substituído pela ornamentação da casa e pela costura de roupas para seus filhos, a fim de "tornar os dias realizados e belos", caber na rotina que a ela foi imposta, caindo em um "destino de mulher". Dessa forma, a "íntima desordem" - a qual move o sujeito artista, como definiu Marcuse da personagem fica como uma chama apagada em seu interior, mas que pode sempre ser reacendida, como demonstra o conto. Talvez essa tenha sido a história de muitas mulheres que, possuindo o desejo e o dom da arte, não se tornaram artistas; pelo contrário: as regras da comunidade social as fizeram se desenvolver artisticamente apenas no âmbito que seria reservado a elas: a casa e a maternidade.

Aproximando-se dessa ideia, o conto "Devaneio e embriaguez duma rapariga"124 também pode, a sua maneira, provocar uma reflexão sobre a posição distanciada das mulheres em relação à arte, devido às normas sociais - no momento em que a protagonista portuguesa,

\footnotetext{
${ }^{123}$ LISPECTOR, Clarice. "Amor". In: Todos os contos. Org. Benjamin Moser. Rio de Janeiro: Rocco, 2016, p. 146.

${ }^{124}$ Devo a sugestão de inserir esse conto aqui a Gilberto Figueiredo Martins, que apontou como o aspecto pictórico está também presente nessa pequena narrativa.
} 
ao observar o "quadro de uvas e peras e peixe morto brilhando nas escamas" ${ }^{125}$ disposto na parede de um restaurante, pensa que poderia, sim, fazer outras cousas (talvez até artísticas):

Ao mesmo tempo, que sensibilidade! mas que sensibilidade! quando olhava o quadro tão bem pintado do restaurante ficava logo com sensibilidade artística. Ninguém lhe tiraria cá das ideias que nascera mesmo para outras cousas. Ela sempre fora pelas obras d'arte. ${ }^{126}$

Há outro conto que, a sua maneira, apresenta atividades que se aproximam do ato artístico, utilizadas para fins domésticos: "A quinta história", que será melhor explorado na próxima seção deste trabalho, pelas suas semelhanças com A paixão segundo G.H., conforme já comentadas pela crítica. Neste conto, a narradora ensina uma fórmula para se exterminar as baratas do seu condomínio: a mistura de gesso, açúcar e farinha - os dois últimos atrairiam esses insetos para comer a receita preparada, e, assim, seriam assassinados ("engessados") a partir de seu interior, conservando intacto o seu exterior; o que os transformam em pequenas estátuas, as quais a narradora, inclusive, relaciona com os corpos petrificados de Pompéia. A partir, então, de uma receita caseira, em um escrito que, inicialmente, parece uma simples fórmula para outras mulheres acabarem com esses insetos, a narradora demonstra seu instinto perverso e, de certa forma, quase artístico, ao esculturar as baratas mortas e até apreciá-las como se estivesse contemplando a arte de um museu - ou os esqueletos de Pompéia.

Para além de todos esses contos citados, que trazem, de maneiras distintas, o tema em questão, a arte visual aparecerá, principalmente, em três romances com protagonistas femininas, duas das quais já são postas como artistas: em Água viva, tem-se uma narradorapintora; em A paixão segundo G.H. e O lustre, a escultura se faz presente (mesmo nesse último apenas apareça a arte como meio de lazer da protagonista e não exatamente uma forma de arte). Por fim, vale mencionar que Ângela Pralini, de Um sopro de vida, também se mostra interessada pela pintura, além da música, apesar de não se dedicar de fato a nenhuma dessas modalidades.

Nota-se, assim, como o tema da arte e do artista, a reflexão sobre a arte e a metalinguagem, e até a transformação, no caso feminino, da arte em atividades cotidianas adequadas às funções da mulher, percorrem toda a obra clariceana, desde as entrevistas, passando pelos seus textos jornalísticos, até sua ficção propriamente dita. Ao investigar seus escritos em busca dessa temática, é possível notar como ela é abrangente no trabalho de

\footnotetext{
${ }^{125}$ LISPECTOR, Clarice. "Devaneio e embriaguez duma rapariga". In: Todos os contos. Org. Benjamin Moser. Rio de Janeiro: Rocco, 2016, p. 140.

${ }^{126}$ Ibidem.
} 
Clarice, cuja narrativa de A paixão segundo G.H., que aqui se pretende analisar, é fruto e reflexo: G.H. é também uma artista e apresentará discussões, no seu relato, sobre a arte, como se verá adiante no estudo.

\subsection{A arte e os personagens artistas na crítica clariceana}

Dentre a fortuna crítica de Clarice Lispector, alguns autores já trabalharam, mesmo que minimamente, com a aproximação entre as narrativas da escritora e outras artes, como a pintura, a música, o desenho e a escultura. Merecem destaque: Regina Pontieri ${ }^{127}$, Carlos Mendes de Sousa ${ }^{128}$, Solange Ribeiro de Oliveira ${ }^{129}$, Lúcia Peixoto Cherem ${ }^{130}$ e Ivan Hegenberg ${ }^{131}$.

Regina Pontieri, em Clarice Lispector: uma poética do olhar, desenvolve dois pontos que contribuem para essa reflexão. O primeiro é que, no romance $A$ cidade sitiada, haveria "o predomínio da técnica descritiva, integrada a um tecido imagético de apelo fortemente visual"132; assim, esse romance teria certas aproximações com a pintura - nas palavras de Pontieri: haveria uma lógica do "ver como pintar"133. O outro é a definição de Joana, de Perto do coração selvagem, como uma "artista em formação"134.

Por seu poder de imaginação criadora, Joana garante a superioridade entre as colegas de escola (...). Nesse sentido, Perto do coração selvagem conta não só a errância de uma mulher ao longo de vários estágios da vida, mas também um aprendizado de escritura. E esse fato justifica considerá-lo como romance de formação, tanto quanto Um retrato do artista quando jovem de onde procede o título de Clarice. ${ }^{135}$

127 PONTIERI, Regina. Clarice Lispector: uma poética do olhar. Cotia, São Paulo: Ateliê Editorial, 2001.

128 SOUSA, Carlos Mendes de. Clarice Lispector: Figuras da escrita. Minho, Portugal: Universidade do Minho, 2001.

Clarice Lispector: Pinturas. Rio de Janeiro: Rocco, 2013.

129 OLIVEIRA, Solange Ribeiro de. Literatura e artes plásticas: O Künstlerroman na ficção contemporânea. Ouro Preto, Minas Gerais: Editora na UFOP, 1993.

Belo Horizonte, v. 27, n. 2, p. 261-276.

"Literatura e pintura abstrata: Água viva de Clarice Lispector". Aletria,

130 CHEREM, Lúcia Peixoto. As duas Clarices - entre a Europa e a América: leitura e tradução de Clarice Lispector na França e no Quebec. Curitiba, Paraná: Editora UFPR, 2013.

131 HEGENBERG, Ivan. Clarice Lispector e as fronteiras da linguagem: uma leitura interdisciplinar do romance Água viva. São Paulo: Benjamin Editorial, 2018.

132 PONTIERI, 2001, p. 26.

133 Ibidem, p. 185.

134 Ibidem, p. 169.

135 Ibidem, p. 105. 
Carlos Mendes de Sousa, por sua vez, possui dois livros que tratam dessa aproximação: em Clarice Lispector: figuras da escrita, o autor dedica todo um capítulo para analisar o papel do desenho, da pintura e da escultura nas obras clariceanas. Apesar de desenvolver mais profundamente uma análise sobre a pintura em Água viva, o autor também aponta, mesmo que de forma concisa, a questão da escultura em A paixão segundo G.H., afirmando que, nesse romance, a arte apontada não seria um tema principal do romance, mas constituiria apenas "uma primeira abertura à tematização da reflexão sobre a arte"136, no conjunto de obras da autora. Sousa ainda desenvolveu outro livro sobre a relação da autora com outras artes, averiguando as pinturas da própria Clarice, refletindo sobre elas, sobre a vida da autora e sobre algumas de suas obras literárias conjuntamente. Sobre as pinturas de Clarice, há, também, o livro de Ricardo Ianacce, Retratos em Clarice Lispector ${ }^{137}$, que trabalha uma interpretação das obras pintadas por Clarice em conjunto com sua escrita.

Em Literatura e Artes Plásticas: o Künstlerroman na ficção contemporânea, Solange Ribeiro de Oliveira desenvolve a teoria do Künstlerroman no romance A paixão segundo G.H.. Ainda que a autora não tenha buscado o trabalho de Herbert Marcuse para definir o Künstlerroman, mostra-se imprescindível averiguar como ela tece essa aproximação. A mesma autora também escreveu o artigo "Literatura e pintura abstrata: Água viva de Clarice Lispector", no qual reforça o caráter abstrato desse romance, retomando a crítica artística sobre o abstracionismo e comparando essa escrita principalmente com obras de Wassily Kandinsky.

Verificando os estudos de Heléne Cixous e Claire Varin, Lúcia Peixoto Cherem, em As duas Clarices - entre a Europa e a América: leitura e tradução da obra de Clarice Lispector na França e no Quebec, resume a aproximação feita por essas autoras entre o romance Água Viva e a pintura. Além disso, Cherem separa um capítulo específico de seu livro para aproximar a música do romance $A$ hora da estrela, também retomando os estudos de Claire Varin.

O estudo mais recente aqui apontado é de Ivan Hegenberg. Resultado de sua dissertação de Mestrado, seu livro Clarice Lispector e as fronteiras da linguagem: uma leitura interdisciplinar do romance Água viva busca analisar o romance Água viva também comparando a linguagem literária com a pictórica. Ainda, o autor traz para sua análise as expressões artísticas dos anos 1970, revelando, assim, a "crise da pintura", crescente na

\footnotetext{
136 SOUSA, 2000, p. 284.

${ }^{137}$ IANNACE, Ricardo. Retratos em Clarice Lispector: literatura, pintura e fotografia. Belo Horizonte, Minas Gerais: Editora UFMG, 2009.
} 
época, como sendo, talvez, a própria voz do romance - ou seja, como sendo a voz da protagonista, pintora não nomeada.

Além desses livros, há outros textos que tentam aproximar as obras de Clarice com as artes visuais. Por exemplo, em "A escrita pictórica em A cidade sitiada, de Clarice Lispector", Rejane Granato Santos e Enilce Albergaria Rocha destacam a predominância do elemento descritivo nesta obra de Clarice, tendo como base, principalmente, o livro já referido de Regina Pontieri, e comparando esse elemento em A cidade sitiada com algumas obras das vanguardas européias do início século XX. ${ }^{138}$

Amaury Jorge Lins Leal, em "Clarice Lispector, Jackson Pollock e a técnica de composição do expressionismo abstrato", aproxima, com base na técnica do expressionismo abstrato e do action-painting, as obras Água viva, de Clarice Lispector, e o quadro Ritmo de Outono, de Jackson Pollock, focando no desejo de captura do "instante-já" que a protagonista clariceana apresenta e o tema do instante do ato criador de Pollock. ${ }^{139}$

Já Flávia Lins e Silva também estuda a obra Água viva, mas com foco tanto no papel da pintura quanto da música e da fotografia no romance. Em seu artigo "'O figurativo do inominável': aspectos da criação textual em Água viva, de Clarice Lispector", ela apresenta sua ideia de que essa obra de Clarice seria como uma espécie de "livro de ateliê", no qual a protagonista-pintora parece buscar nessas três artes certa complementaridade para a escrita. ${ }^{140}$ Em resumo, de acordo com sua interpretação:

Da fotografia, a narradora toma de empréstimo a captação do instante, o fluxo gerado pela imediatez e espontaneidade das palavras; da música, o ritmo, a vibração, a imanência obtidos pela escrita que foge da explicitação de um fato ou história, tornando-se autônoma, e a improvisação, que torna mais importante o gesto produtor do que o produto; da pintura da modernidade, mais uma vez a autonomia em relação a referências externas e a captação do instante através do gesto criador que se incorpora à obra. ${ }^{141}$

Por fim, um artigo recente de Mariângela Alonso, intitulado "Deformações da interioridade: marcas expressionistas em $O$ lustre, de Clarice Lispector"142, explora como a

\footnotetext{
138 SANTOS, Rejane Granato; ROCHA, Enilce Albergaria. "A escrita pictórica em A cidade sitiada, de Clarice Lispector". Ipotesi, Juiz de Fora, v. 9, n. 1, n. 2, p. 155-166, jan/jun, jul/dez 2005.

139 LEAL, Amaury Jorge Lins. "Clarice Lispector, Jackson Pollock e a técnica de composição do expressionismo abstrato". Cerrados, Brasília, n. 7, p. 53-61, 1998.

140 SILVA, Flávia Lins e. "'O figurativo do inominável': aspectos da criação textual em Água viva, de Clarice Lispector". Em tese, Belo Horizonte, v. 8, p. 101-110, dez. 2004.

141 Ibidem, p. 106.

142 ALONSO, Mariângela. "Deformações da interioridade: marcas expressionistas em O lustre, de Clarice Lispector". Opiniães, São Paulo, n. 15, p. 213-235, 2019.
} 
estética expressionista pode ser notada nesse romance clariceano. Diz ela, ao se analisar trechos de $O$ lustre junto do Expressionismo: "na narrativa em tela observamos semelhanças quanto ao modo de composição expressionista, sobretudo no que diz respeito à ausência de figuração concreta da personagem Virgínia, à fragmentação de seu discurso pelo fluxo de consciência e às deformações de paisagens e pessoas representadas. (...) a motivação principal dos procedimentos expressionistas parece residir em $O$ lustre na manutenção de certa visão grotesca e angustiada da protagonista, visto que corroboram o mal estar diante do mundo." 143

Dessa maneira, nota-se brevemente como a crítica já tentou ler as obras de Clarice Lispector comparando-as com outras artes. Nota-se, também, a predominância dessa leitura comparativa sobre o romance Água viva, principalmente no que concerne a sua aproximação com a pintura. Com a ajuda desses trabalhos, pretende-se ampliar, aqui, essa área de estudo sobre os escritos clariceanos a partir do tema da escultura, com foco na análise de A paixão segundo G.H. - o primeiro dos romances da autora que apresenta, de fato, uma personagem artista, e o único a mostrar uma escultora.

143 Ibidem, p. 230-231. 


\section{A ESCULTURA NA FICÇÃO CLARICEANA: TRÊS EXEMPLOS COMPARADOS}

\subsection{A escultura do mal: matando baratas}

É mais do que clara a semelhança temática e formal do conto "A quinta história" com A paixão segundo G.H.. Como estudado por Yudith Rosenbaum: "Pode-se dizer que A paixão segundo G.H. é a continuação de "A quinta história", que foi interrompida no último parágrafo, mostrando o que teria acontecido à nossa "bem-sucedida" narradora se ela desistisse de sua empreitada épica e se deixasse tocar pela inexpressividade do neutro"144. Neste conto, a narradora, justificando-se pelo seu pavor de baratas, ensina uma receita para matá-las, exterminando sua vida interior e conservando seu exterior, transformando-as em pequenas estátuas.

Assim, já é possível notar, estão, as diferenças do tratamento da barata em cada uma dessas duas narrativas que, aqui, se quer comparar: enquanto no conto "evita-se justamente o contato violento e desagregador com essa potência pré-humana que a barata simboliza"145, em G.H. há o contato mais profundo da narradora escultora com o animal pré-histórico, a partir da ingestão do seu de dentro, identificando-se, de maneira mais intensa, vítima e agressor - e tal "identificação entre vítima e agressor"146 também ocorre, de maneira diferente, em "A quinta história", como demonstrou Rosenbaum a partir de trechos do conto: "'Um medo excitado e meu próprio mal secreto me guiavam'; ou ainda: 'Como para baratas espertas como eu..."'147. Enquanto G.H. mata, na porta do armário, a barata, partindo-a em duas e deixando o seu de dentro se manifestar em uma espécie de ovulação externa de sua matéria neutra e depois ingerindo-o, a narradora do conto pretende justamente matar o de dentro conservando o de fora, transformando, portanto, as baratas em estátuas aparentemente perfeitas, visto sua conservação externa, em detrimento do ressecamento interno. Assim, uma matança parece ser o avesso da outra, trazendo consequências e reflexões diversas para cada uma das narrativas - e para cada uma das baratas.

\footnotetext{
144 ROSENBAUM, Yudith. Metamorfoses do mal: uma leitura de Clarice Lispector. São Paulo: EDUSP: FAPESP, 2006, p. 149.

145 Ibidem.

${ }^{146}$ Ibidem, p. 136.

${ }^{147}$ Ibidem.
} 
Além disso, a escrita em forma de espiral, com seus diversos encaixes, aproximandose da técnica denominada mise en abyme ${ }^{148}$ (que será melhor analisada no capítulo posterior, sobre A paixão segundo G.H.), também é presente em ambas as narrativas. As duas, portanto, retornam "ao ponto de origem para desdobrá-lo [o conto] e complicá-lo" ${ }^{149}$, funcionando como "mônadas que recontam uma mesma e outra história"150, a partir da repetição dos trechos finais dos capítulos de G.H. em cada nova parte e a repetição do argumento da narradora do conto ao contar cada uma de suas cinco histórias: "Começa assim: queixei-me de baratas"151. Em G.H., como se verá melhor adiante, essa repetição na forma de narrar pode se assemelhar justamente ao fazer escultórico, ao passo que este, no movimento de modelar e remodelar, pode fazer e desfazer a imagem tridimensional no trabalho com as mãos, tal qual as narradoras das duas obras o fazem contando suas histórias na arte verbal - modo de salvação a partir da semelhança com Sherazade: a escrita, feita e refeita no processo narrativo, seria para essas protagonistas, como era para a própria Clarice (e para Sherazade), uma forma de sobreviver, uma maldição que salvaria essas mulheres de conviverem sozinhas com seus crimes.

Finalmente, outra visível semelhança é que o inseto comum entre as duas narrativas também se faz escultura em ambas as obras. A barata, símbolo da vida pré-humana, inseto antigo datado dos primórdios do mundo, faz ambas as narradoras se confrontarem consigo mesmas e com o mal próprio de cada uma, como já analisado por Rosenbaum. No entanto, o modo de esculpir essa barata se dará de forma diferente em cada uma - não só devido ao modo de matá-las, mas também devido aos motivos e às consequências dos enredos.

Em "A quinta história", a escultura é fruto não de um fazer artístico genuinamente pensado por uma escultora, mas sim - como também já refletiu Rosenbaum - de uma atitude sádica mascarada de uma ingênua receita para donas de casa:

Esta história poderia chamar-se "As Estátuas". Outro nome possível é "O Assassinato". E também "Como Matar Baratas". Farei então pelo menos três histórias, verdadeiras, porque nenhuma delas mente a outra. Embora uma única, seriam mil e uma, se mil e uma noites me dessem.

A primeira, "Como Matar Baratas", começa assim: queixei-me de baratas. Uma senhora ouviu-me a queixa. Deu-me a receita de como matá-las. Que misturasse em partes

\footnotetext{
148 C.f.: ALONSO, Mariângela. "Um enredamento de baratas: a mise en abyme em 'A quinta história', de Clarice Lispector". Estação Literária, Londrina, v. 7, 2011.

149 ROSENBAUM, 2006, p. 131.

150 Ibidem, p. 145.

${ }^{151}$ LISPECTOR, Clarice. "A quinta história". In: Todos os contos. Rio de Janeiro: Rocco, 2016, p. 335-337.
} 
iguais açúcar, farinha e gesso. A farinha e o açúcar as atrairiam, o gesso esturricaria o dedentro delas. Assim fiz. Morreram. ${ }^{152}$

A primeira história é justamente a narradora nos fornecendo o passo a passo do assassinato: a mistura de açúcar, farinha e gesso, que seduziria a barata para matá-la de dentro para fora, tornando-a um objeto inanimado, escultórico enfim. Mas a real aproximação da barata esturricada com a escultura se dá na terceira história:

A terceira história que ora se inicia é a das "Estátuas". Começa dizendo que eu me queixara de baratas. Depois vem a mesma senhora. Vai indo até o ponto em que, de madrugada, acordo e ainda sonolenta atravesso a cozinha. Mais sonolenta que eu está a área na sua perspectiva de ladrilhos. E na escuridão da aurora, um arroxeado que distancia tudo, distingo a meus pés sombras e brancuras: dezenas de estátuas se espalham rígidas. As baratas que haviam endurecido de dentro para fora. Algumas de barriga para cima. Outras no meio de um gesto que não se completaria jamais. Na boca de umas um pouco da comida branca. Sou a primeira testemunha do alvorecer em Pompéia. Sei como foi esta última noite, sei da orgia no escuro. Em algumas o gesso terá endurecido tão lentamente como num processo vital, e elas, com movimentos cada vez mais penosos, terão sofregamente intensificado as alegrias da noite, tentando fugir de dentro de si mesmas. Até que de pedra se tornam, em espanto de inocência, e com tal, tal olhar de censura magoada. Outras - subitamente assaltadas pelo próprio âmago, sem nem sequer ter tido a intuição de um molde interno que se petrificava! - essas de súbito se cristalizam, assim como a palavra é cortada da boca: eu te... Elas que, usando o nome de amor em vão, na noite de verão cantavam. Enquanto aquela ali, a de antena marrom suja de branco, terá adivinhado tarde demais que se mumificara exatamente por não ter sabido usar as coisas com a graça gratuita do em vão: "é que olhei demais para dentro de mim! é que olhei demais para dentro de..." - de minha fria altura de gente olho a derrocada de um mundo. Amanhece. Uma ou outra antena de barata morta freme seca à brisa. Da história anterior canta o galo. ${ }^{153}$

Irônica a comparação com Pompéia, local conhecido pela erupção do vulcão Vesúvio, petrificando ( $\mathrm{e}$, portanto, tornando estátuas) os moradores da cidade que não conseguiram fugir do desastre natural. No entanto, a morte das baratas nada tinha de natural - pelo contrário: uma força impulsiva e violenta de uma dona de casa faz, desses insetos, esculturas, a partir da petrificação e da consequente morte do interior dos animais; da mais pura vontade de matar (usando os termos da própria Clarice sobre o assassinato em "Mineirinho") surgem essas pequenas estátuas. Forma incomum do fazer escultórico: apesar de Pompéia ser, de fato, um destino turístico próprio para se ver a população agora petrificada, realmente em forma semelhantemente escultórica a partir da erupção vulcânica em contato com os corpos, tal população não foi esturricada de dentro para fora como foram as baratas clariceanas. Assim, essas estátuas sevandijas nada têm de tradicional: a escultura do inseto parece ser

\footnotetext{
152 Ibidem, p. 335.

153 Ibidem, p. 336-337, grifos meus.
} 
mais uma consequência "natural" de um processo homicida artificial e incomum de se dedetizar essa presença grotesca e indesejável - e também um modo de transformá-las em uma forma que alude à arte escultórica, uma vez que a narradora as mata e as traz para o conto como construções estéticas. Tal como um desejo de tirar de dentro de si própria o mal que se contradiz com a benevolência e a pureza desejosas pelo sujeito ${ }^{154}$.

A barata de G.H., por sua vez, se faz escultura a partir de outro processo: a descrição - aqui entendida e estudada enquanto écfrase - da protagonista narradora para contar sua experiência. Em A paixão segundo G.H., como se analisará mais detalhadamente adiante, a escultura da barata se faz de forma verbal - já que a barata é, na realidade de G.H., inseto -, como se fosse uma escrita escultórica, transformando apenas no plano narrativo a barata em escultura. Dessa forma, a barata não seria uma estátua na realidade de G.H. - como acabou sendo na realidade de "A quinta história", após a matança dos insetos -, mas apenas no plano em que a história se transforma em narrativa, na hora em que a protagonista decide contar ao leitor a sua vivência com ela, transformando-a, assim, em um objeto da sua arte a partir de um recurso da antiguidade clássica, descrevendo-a com o intuito de colocá-la imageticamente aos olhos do leitor. Outra maneira incomum de se fazer escultura: utilizando do plano verbal para transformar um objeto tridimensional em uma espécie de narrativa descritiva tridimensional, vívida e enérgica para o leitor, a fim de que este tenha a experiência mais próxima com o inseto tal como G.H. o teve.

Duas narrativas, duas experiências, duas esculturas diferentes das baratas, porém ambas não usuais. A barata clariceana é transformada em escultura ora para tranquilizar os ânimos desesperados da dona de casa, petrificando-se, imobilizando-se para contemplação sádica da assassina; ora para fazer a artista escultora desumanizar-se, a partir não de uma espécie de arrependimento pela morte do inseto, mas de uma subsequente identificação entre eu e outro nos níveis mais profundos possíveis com a ingestão do neutro do animal - ignorado e executado no conto. Enquanto a protagonista do conto em nada transcende com seu crime, mas apenas o relata disfarçado de uma ação em prol de um bem comum ${ }^{155}$, G.H. usa sua experiência para provar do maligno, transcendendo a ordem civilizatória, podendo, enfim, tornar-se uma escultora efetivamente dita, indissociada da sociedade e de seu utilitarismo da

\footnotetext{
154 Como também escreveu Rosenbaum: "Chama a atenção a dicotomia entre "eu" e "alma"("eu ou minha alma"), como se fossem esferas psíquicas inconciliáveis: a primeira, marcada pelo expurgo do mal; a segunda, sacrificada em nome da isenção e da pureza" (2006, p. 145)

155 "A verdade é que só em abstrato me havia queixado de baratas, que nem minhas eram: pertenciam ao andar térreo e escalavam os canos do edifício até o nosso lar. Só na hora de preparar a mistura é que elas se tornaram minhas também. Em nosso nome, então, comecei a medir e pesar ingredientes numa concentração um pouco mais intensa." (LISPECTOR, 2016, p. 335, meus grifos)
} 
vida burguesa, após um processo de libertação e purificação social a partir de uma "construção estética nada inocente da inocência"156 - ingerir, justamente, do impuro para purificar-se da construção civilizatória. Transformando-se, enfim, em uma artista (im)perfeita.

\subsection{O artista em criação: $O$ lustre e $A$ paixão segundo G.H.}

Mas o que ela amava acima de tudo era fazer bonecos de barro, o que ninguém lhe ensinara. Trabalhava numa pequena calçada de cimento em sombra, junto à última janela do porão. Quando queria com muita força ia pela estrada até o rio. Numa de suas margens, escalável embora escorregadia, achava-se o melhor barro que alguém poderia desejar: branco, maleável, pastoso, frio. Só em pegá-lo, em sentir sua delicadeza alegrezinha e cega, aqueles pedaços timidamente vivos, o coração da pessoa se enternecia úmido, quase ridículo. Virgínia cavava com os dedos aquela terra pálida e lavada - na lata presa à cintura iam-se reunindo os trechos amorfos. O rio em pequenos gestos molhava-lhe os pés descalços e ela mexia os dedos miúdos com excitação e clareza. Com as mãos livres, então, cuidadosamente galgava a margem até a extensão plana. No pequeno pátio de cimento depunha sua riqueza. Misturava o barro à água as pálpebras frementes de atenção - concentrada, o corpo à escuta, ela podia obter uma proporção exata e nervosa de barro e de água numa sabedoria que nascia naquele mesmo instante, fresca e progressivamente criada. Conseguia uma matéria clara e tenra de onde se poderia modelar um mundo. Como, como explicar o milagre... Amedrontava-se pensativa. Nada dizia, não se movia mas interiormente sem nenhuma palavra repetia: eu não sou nada, não tenho orgulho, tudo pode me acontecer, se--- quiser me impedirá de fazer a massa de barro - se quiser pode me pisar, me estragar tudo, eu sei que não sou nada.--- era menos que uma visão, era uma sensação no corpo, um pensamento assustado sobre o que the permitia conseguir tanto no barro e na água e diante de quem ela devia humilhar-se com seriedade. Agradecia-lhe com uma alegria difícil, frágil e tensa, sentia em--- alguma coisa como o que não se vê de olhos fechados - mas o que não se vê de olhos fechados tem uma existência e uma força, como o escuro, como o escuro, como a ausência, compreendia-se ela assentindo, feroz e muda com a cabeça. Mas nada sabia de si própria, passaria inocente e distraída pela sua realidade sem reconhecê-la, como uma criança, como uma pessoa.

Depois de obtida a matéria, numa queda de cansaço ela poderia perder a vontade de fazer bonecos. Então ia vivendo para a frente como uma menina.

Um dia porém sentia seu corpo aberto e fino e no fundo uma serenidade que não se podia conter, ora se desconhecendo ora respirando em alegria, as coisas incompletas. Ela mesma insone como luz - esgazeada, fugaz, vazia, mas no fundo um ardor que era vontade de guiar-se a uma só coisa, um interesse que fazia o coração acelerar-se sem ritmo... de súbito como era vago viver. Tudo isso também poderia passar, a noite caindo subitamente, a escuridão sobre o dia morno. Mas às vezes lembrava-se do barro molhado, corria assustada para o pátio - mergulhava os dedos naquela mistura fria, muda e constante como uma espera, amassava, amassava, aos poucos ia extraindo formas. Fazia crianças, cavalos, uma mãe com um filho, uma mãe sozinha, uma menina fazendo coisas de barro, um menino descansando, uma menina contente, uma menina vendo se ia chover, uma flor, um cometa de cauda salpicada de areia lavada e faiscante, uma flor murcha com sol por cima, o cemitério de Brejo Alto, uma moça olhando... Muito mais, muito mais. Pequenas formas que nada significavam mas que eram na realidade misteriosas e calmas. Às vezes altas como uma árvore alta, mas não eram árvores, não eram nada... Às vezes como um riozinho correndo, mas não eram rio, não eram nada... Às vezes um pequeno objeto de forma quase estrelada mas cansado com

156 RUFINONI, Simone. Op. cit, p. 360. 
uma pessoa. Um trabalho que acabaria, isso era o que de mais bonito e cuidadoso já soubera: pois se ela podia fazer o que existia e o que não existia!

Depois de prontos os bonecos eram colocados ao sol. Ninguém lhe ensinara mas ela os depositava nas manchas de sol no chão, manchas sem vento nem ardor. $\mathrm{O}$ barro secava mansamente, conservava o tom claro, não enrugava, não rachava. Mesmo quando seco parecia delicado, evanescente e úmido. E ela própria podia confundi-lo com o barro pastoso. As figurinhas assim pareciam rápidas quase como se fossem se movimentar. Olhava o boneco imóvel. Por amor ou apenas prosseguindo no trabalho fechava os olhos e concentrava-se numa força viva e luminosa da qualidade do perigo e da esperança, numa força de seda que lhe percorria o corpo celeremente com um impulso que se destinava à figura. Quando enfim se abandonava, seu fresco e cansado bem-estar vinha de que ela podia enviar embora não soubesse o quê.--- talvez. Sim, ela às vezes possuía um gosto dentro do corpo, um gosto alto e angustiante que tremia entre a força e o cansaço - era um pensamento como sons ouvidos, uma cor no coração. Antes que ele se dissolvesse maciamente rápido no seu ar interior, para sempre fugitivo, ela tocava com os dedos num objeto, entregando. E quando queria dizer algo que vinha tênue, obscuro e liso e isso poderia ser perigoso, encostava um dedo apenas, um dedo pálido, polido e transparente - um dedo trêmulo de direção. No mais fino e doído de seu sentimento ela pensava: vou ser feliz. Na verdade o era nesse instante e se em vez de pensar "sou feliz" procurava o futuro era porque obscuramente escolhia um movimento para a frente que servisse de forma à sua sensação.

Assim juntara uma procissão de coisas miúdas. Quedavam-se quase despercebidas no seu quarto. Eram bonecos magrinhos e altos como ela mesma. Minuciosos, ligeiramente desproporcionados, alegres, um pouco surpreendidos - às vezes pareciam um homem coxo rindo! Mesmo suas figurinhas mais suaves tinham uma imobilidade vigilante como a de um santo. E pareciam inclinar-se para quem as olhava como os santos. Virgínia podia fitá-las uma manhã inteira e seu amor e sua surpresa não diminuiriam.

- Bonito... bonito como uma coisinha molhada! dizia excedendo-se num ímpeto doce.

Observava: mesmo bem-acabados eles eram toscos como se pudessem ainda ser trabalhados. Mas vagamente pensava que nem ela nem ninguém poderia tentar aperfeiçoálos sem destruir sua linha de nascimento. Era como se eles só pudessem se aperfeiçoar por eles mesmos, se isso fosse possível.

$\mathrm{E}$ as dificuldades surgiam como uma vida que vai crescendo. Seus bonecos, pelo efeito do barro claro, eram pálidos. Se queria sombreá-los não o conseguia com auxílio da cor e por força dessa deficiência aprendeu a dar-lhes sombra ainda por meio da forma. Depois inventou uma liberdade: com uma folhinha seca sob um fino traço de barro conseguia um vago colorido, triste e assustado, quase inteiramente morto. Misturando barro à terra obtinha outro material menos plástico, porém mais severo e solene. Mas como fazer o céu? Nem começar podia. Não queria nuvens - o que poderia obter pelo menos grosseiramente - mas o céu, o céu mesmo, com a sua inexistência, cor solta, ausência de cor. Descobriu que precisava usar matérias mais leves que não pudessem sequer ser apalpadas, sentidas, talvez apenas vistas, quem sabe. Compreendeu que isso se conseguiria com tintas.

E às vezes numa queda, como se tudo se purificasse - ela se contentava em fazer uma superfície lisa, serena, unida, numa simplicidade fina e tranquila. ${ }^{157}$

Este longo trecho de $O$ lustre demonstra uma atividade que a protagonista Virgínia que, para Solange Ribeiro de Oliveira, seria "um primeiro esboço da escultora G.H."158_ costumava realizar: fazer bonecos de barro, como se fossem pequenas esculturas elaboradas

\footnotetext{
${ }^{157}$ LISPECTOR, Clarice. O lustre. Rio de Janeiro: Rocco, 1999, p. 44-48.

158 OLIVEIRA, Solange Ribeiro de. A barata e a crisálida: o romance de Clarice Lispector. Rio de Janeiro: José Olympio, 1985, p. 5.
} 
a partir de um material mais simplório. Além de também explanar uma espécie de passo a passo do esculpir dessas figuras - pegar o barro nas margens do rio, misturá-lo à água, moldar essa matéria, colocá-la ao sol e, voilà, os bonecos -, nota-se como o trabalho manual modela a matéria, podendo, também, remodelá-la - como o labor "com uma folhinha seca sob um fino traço de barro conseguia um vago colorido, triste e assustado, quase inteiramente morto"; ou, ainda, com a experimentação de um novo material ao se misturar barro e terra ao invés de barro e água. O trabalho com a mão, aqui, ocorre de forma mais genuína e até arcaica: tocar, de fato, o solo, quando "cavava com os dedos aquela terra pálida e lavada", obtendo um material simples, porém efetivo para a construção das pequenas estátuas: o barro. G.H. também faz pequenas formas com materiais triviais, como o pão: "Eu podia, com muito menos do que eu era, eu já podia usar tudo: exatamente como ontem, à mesa do café, me bastava, para formar formas redondas de miolo de pão, a superfície de meus dedos e a superfície do miolo de pão"159 - contradizendo, de certa forma, a reflexão de Manuel Bandeira sobre a escultura no Brasil ser uma arte cara, por conta do material e do modelo necessários a essa arte (aqui, não há necessidade de um material mais complexo, suntuoso e inacessível, muito menos de um modelo para esculpir). Ao utilizarem esses materiais e ao fazerem esculturas de imagens simples (como as bolinhas com o pão e os bonecos mais comuns de barro), há a demonstração, de certa forma, de como essa arte pode, a sua maneira, sair de seu pedestal e tocar nos âmbitos mais populares. ${ }^{160}$

$\mathrm{O}$ ato descrito no trecho de $O$ lustre pode, também, ser uma espécie de "metáfora da criação", como analisou Mariângela Alonso: "Grosso modo, pode-se dizer que as brincadeiras com as estatuetas de barro engendram a própria representação do artista em seu processo de criação. Como uma espécie de demiurgo, Virgínia artesã de si mesma procura modelar e organizar a matéria caótica e disruptiva por meio do barro"161.

\footnotetext{
${ }^{159}$ LISPECTOR, Clarice. A paixão segundo G.H.. Rio de Janeiro: Rocco,

${ }^{160}$ Da mesma forma, parece ser possível aproximar um pequeno trecho em que Rodrigo S.M., narrador de $A$ hora da estrela, caracteriza Olímpico de Jesus: "[Olímpico] não sabia que era um artista: nas horas de folga esculpia figuras de santo e eram tão bonitas que ele não as vendia. Todos os detalhes ele punha e, sem faltar ao respeito, esculpia tudo do Menino Jesus. Ele achava que o que é, é mesmo, e Cristo tinha sido além de santo um homem como ele, embora sem dente de ouro" (LISPECTOR, 1998, p. 46). Apesar de não adentrar mais nesse aspecto de Olímpico e, portanto, não elucidar como exatamente ele fazia suas esculturas, pode ser possível analisar que, em $A$ hora da estrela, essa técnica parece também tocar as camadas mais populares - pois Olímpico, um nordestino que, como Macabéa, migra da Paraíba para o Rio de Janeiro, onde consegue um trabalho como operário em uma metalúrgica, provavelmente não poderia ter os recursos necessários para se comprar todo o caro material que Bandeira aponta em sua crônica.

${ }^{161}$ ALONSO, Mariângela. A água e as pulsões em O lustre, de Clarice Lispector. Curitiba: Appris, 2019, p. 118.
} 
Moldando e remoldando, fazendo e desfazendo, escrevendo e reescrevendo: eis o processo artístico até a finalização de sua obra. Esse método de organizar o caos faz parte do trabalho do artista, e aparece tanto em Virgínia, como demonstrado por Alonso, quanto em G.H.. A desorganização, para essas duas escultoras, é uma característica, portanto, indesejada:

Já que tenho de salvar o dia de amanhã, já que tenho que ter uma forma porque não sinto força de ficar desorganizada, já que fatalmente precisarei enquadrar a monstruosa carne infinita e cortá-la em pedaços assimiláveis pelo tamanho de minha boca e pelo tamanho da visão de meus olhos, já que fatalmente sucumbirei à necessidade de forma que vem de meu pavor de ficar delimitada - então que pelo menos eu tenha a coragem de deixar que essa forma se forme sozinha como uma crosta que por si mesma endurece, a nebulosa de fogo que se esfria em terra. E que eu tenha a grande coragem de resistir à tentação de inventar uma forma. ${ }^{162}$

Além disso, o fazer escultórico, ao ter um contato mais direto com a matéria, como já argumentado aqui, opõe-se à escrita também em $O$ lustre - que atinge seu alvo apenas com o intermédio da palavra:

As figuras esculpidas são impregnadas de detalhes significativos do drama existencial que ronda a personagem, que, encantada com o ato criativo, esvazia-se de tudo ao contemplar as formas extraídas de sua mão. Trata-se de um momento epifânico, que se estende ao processo ficcional da própria autora na medida em que atinge nas entrelinhas suscitadas pelo silêncio de Virgínia o poder pulsional da palavra sempre errante, impossível e inatingível. Nesse sentido, sobressai a atuação literária clariciana como "constructo" do discurso literário, na medida em que demonstra a incompletude do ato de escrever e a consciência de que "o escritor não atinge inteiramente o alvo, mas apenas o toca com a palavra". ${ }^{163}$

A mesma ideia de Clarice em suas crônicas, e por isso a preferência pelas artes visuais, que tocariam, de forma mais profunda, o alvo que o artista deseja alcançar:

Ao escrevê-lo, de novo a certeza só aparentemente paradoxal de que o que atrapalha ao escrever é ter de usar palavras. É incômodo. É como se eu quisesse uma comunicação mais direta, uma compreensão muda como acontece às vezes entre pessoas. Se eu pudesse escrever por intermédio de desenhar na madeira ou de alisar uma cabeça de menino ou de passear pelo campo, jamais teria entrado pelo caminho da palavra. Faria o que tanta gente que não escreve faz, e exatamente com a mesma alegria e o mesmo tormento de quem escreve, e com as mesmas profundas decepções inconsoláveis: viveria, não usaria palavras. O que pode vir a ser a minha solução. Se for, bem-vinda. ${ }^{164}$

\footnotetext{
162 LISPECTOR, Clarice. A paixão segundo G.H.. Rio de Janeiro: Rocco, meus grifos.

163 ALONSO, 2019, p. 120.

164 LISPECTOR, Clarice. "Lembrança da feitura de um romance". In: A descoberta do mundo. Rio de Janeiro: Rocco, 2009, p. 285-286.
} 
Ainda nessa comparação entre os dois romances, outra semelhança aparece entre G.H. e Virgínia: a solidão e a introspecção do artista -

A sutileza da cena atesta a necessidade de expressão da personagem, que, em sua solidão, molda figuras de barro, guardando consigo emoções desconhecidas, as quais parecem brotar da atividade manual com água e terra, em estreita ligação com a realidade íntima. (...)

A água misturada com a terra, no entanto, revigora o comportamento viscoso e meditativo de de Virgínia, demonstrando-se em sentidos a partir das figuras de barro. O retorno desse sema liga-se ao esforço e tentativa de compreensão para algo que transcenda a linguagem e o conhecimento da protagonista: "Era como se eles [os bonecos de barro] só pudessem se aperfeiçoar por eles mesmos, se isso fosse possível". ${ }^{165}$

Novamente, o desejo da figura tridimensional escultórica em transcender a linguagem e o conhecimento da personagem. Como em G.H., romance todo construído a partir da tentativa da protagonista de contar o ocorrido, empenhando-se em transcrever tudo de forma que o leitor se sinta como ela se sentira, vendo o que ela vira. Tal é a função da mão inventada: ao narrar a experiência, dando conscientemente uma forma literária a ela, há justamente "esforço e tentativa de compreensão para algo que transcenda a linguagem e o conhecimento da protagonista" provocados pela pintura de Janair e pela barata no guardaroupas.

Transcender a linguagem, organizar o caos, estar consigo mesma em momentos de meditação e solidão, trabalhar efetivamente com as mãos: eis as semelhanças entre Virgínia e G.H.. Se G.H. se dizia uma escultora amadora, trabalhando com seu dom de forma não profissionalizada (retomando as palavras de Clarice: ela própria seria uma escritora amadora, e não uma profissional, porque só escrevia quando queria ${ }^{166}$ ), Virgínia também não se faz uma escultora como profissão, mas utiliza sua experiência com a construção dos bonecos para conhecer a si mesma, passando para essas estátuas as suas próprias emoções, refletindose nelas de várias maneiras:

Antes que ele [o boneco] se dissolvesse maciamente rápido no seu ar interior, para sempre fugitivo, ela tocava com os dedos num objeto, entregando. E quando queria dizer algo que vinha tênue, obscuro e liso e isso poderia ser perigoso, encostava um dedo apenas, um dedo pálido, polido e transparente - um dedo trêmulo de direção. (...)

Eram bonecos magrinhos e altos como ela mesma. ${ }^{167}$

\footnotetext{
165 ALONSO, 2019, p. 120-121, grifos meus.

166 Como a própria Clarice disse em entrevista para Júlio Lerner, disponível no link: $<$ https://www.youtube.com/watch? $\mathrm{v}=$ ohHP112EVnU $>$.

167 Meus grifos.
} 
Se, para Clarice Lispector, a palavra era seu domínio sobre o mundo, para G.H. e Virgínia é a escultura que parece permiti-las ocupar esse lugar. O trabalho visual predominaria, aqui, sobre o verbal, como a própria escritora defendia. Utilizando-se o toque das mãos sobre o material que efetivamente seria a arte, as sensibilidades dessas protagonistas são exibidas, demonstrando suas angústias, suas experiências, seus desertos; transmitindo, assim, uma imagem de si e do mundo que se quer descobrir, investigar, questionar, demonstrar e compreender. A compreensão do mundo passa (literalmente, aqui) também pelo tatear, pelo gesto do tocar como tentativa de ir à coisa. Contudo, pode, ainda, haver a necessidade de uma segunda solução artística: o uso, justamente, da palavra para dar conta de suas experiências - como houve para G.H. a fim de contar o terrível e desestruturante ocorrido. Usando (e invertendo, de certa forma) a consideração da própria Clarice em uma crônica já citada: "não usaria palavras. O que pode vir a ser a minha solução. Se for, bemvinda"168. Se, para G.H., a solução encontrada para transmitir sua experiência for o uso da palavra, transformando seu rito da paixão em literatura, que essa solução seja igualmente bem-vinda.

${ }^{168}$ LISPECTOR, 2009, p. 286. 


\title{
4. A PAIXÃO SEGUNDO G.H.:
}

\section{A TRANSGRESSÃO DO ARTISTA}

\subsection{Breve panorama sobre a fortuna crítica de $A$ paixão segundo G.H.: textos essenciais}

\begin{abstract}
A paixão segundo G.H. é nitidamente configurado sobre a conhecida expressão: "paixão de Jesus Cristo segundo Mateus" ou "Paixão de Jesus Cristo segundo João". A narrativa da "Paixão" é uma parte dos Evangelhos. Significa que os sofrimentos de Cristo são narrados como foram vistos ou conhecidos por seus discípulos. No caso de G.H., a paixão é da protagonista, narrada por ela mesma. Mas a paixão não é só a experiência nauseante de ter comido da massa da barata: engolir a massa branca e insossa, como protótipo da matériaprima do mundo, foi, sem dúvida, uma experiência vital. Narrá-la, porém, foi uma experiência limite, porque a manducação da barata levara G.H. à renúncia de sua vida pessoal, de seu ser como linguagem.

Trata-se do primeiro romance de Clarice Lispector em primeira pessoa. A paixão de G.H. é o sofrimento para chegar à própria identidade a ser alcançada com a despersonalização e a mudez; a paixão segundo G.H. é o sofrimento de narrar esta experiência, que, passando pela manducação da barata, atinge a própria natureza do ser que faz linguagem: o escritor. ${ }^{169}$
\end{abstract}

O trecho retirado da obra de Olga de Sá, em seu livro Clarice Lispector: A travessia do oposto, evoca algumas informações preciosas da crítica em relação a essa obra clariceana. A aproximação com a paixão de Cristo, vinda tanto do título quanto do conteúdo narrativo; a desumanização de G.H. e a consequente renúncia como um ser imbuído de linguagem; a narrativa inédita em primeira pessoa, contradizendo tanto as outras obras de Clarice Lispector quanto os relatos bíblicos da paixão, sempre em terceira pessoa; a dor de se passar a experiência pela linguagem, pela escrita, retomando a maldição clariceana tão encontrada nos seus contos: ser escritora.

O livro de Olga de Sá é um dos mais essenciais para se entender não só essa obra de Lispector, mas todo o seu trabalho. Sobre A paixão segundo G.H. especificamente, Sá foca na comparação da paixão da protagonista com a paixão divina, destacando o pararelismo bíblico e o sentido paródico e paradoxal que ela passa a ter graças ao fato da obra colocar, de certa maneira, em xeque a credibilidade do discurso religioso, que, retomando, nunca é narrado por aquele que passou pelo processo de paixão:

Este romance, cuja dramaticidade está mais no discurso do que nas ações, estrutura-se sobre uma dupla linha de montagem:

${ }^{169}$ SÁ, Olga de. "A reversão paródica da consciência na matéria viva: O signo iconizado - A paixão segundo G.H.". In: Clarice Lispector: A travessia do oposto. São Paulo: Annablume, 2004, p. 124. 
1. o paralelismo bíblico, que se manifesta - como já focalizamos num trabalho anterior ${ }^{170}$ quando, no texto clariceano, um capítulo se inicia com a mesma frase que finaliza o capítulo anterior. Este procedimento repetido (menos no capítulo XIX, que, descartado, deixa o livro com XXXIII capítulos, cifra equivalente à idade de Jesus Cristo, como se diz popularmente) não só estrutura o encadeamento formal da narrativa, mas substitui a oralidade, que ela não tem, pelo procedimento poético, de que é impregnado o texto bíblico (...)

2. o paradoxo, este recurso retórico que diz respeito à questão da credibilidade dos discursos, inclinando os textos bíblicos para o sentido paródico, causa um efeito de perplexidade/estranhamento, que tanto a paródia, como o paradoxo veiculam. ${ }^{171}$

A partir de elementos como a linguagem e o silêncio, a escrita e a dor, caras à narrativa de G.H., as diferentes paixões são comparadas por Sá. A travessia do oposto seria justamente essa em G.H.: a partir do relato em primeira pessoa, além da travessia da paixão a partir do impuro e do imundo, em contraposição com a hóstia sagrada do cristianismo a qual é originada graças à paixão de Jesus, a protagonista passa à deseroização: "Por não ser, ela era"172, como relembra Sá. G.H. é a primeira protagonista clariceana a ter uma voz própria, a narrar sua própria experiência, e, portanto, a primeira que poderia finalmente abrir mão dessa própria voz, da linguagem humana, mesmo esse sendo um desejo próximo de outras personagens como Joana, de Perto do coração selvagem; Virgínia, de O lustre; e Lucrécia de $A$ cidade sitiada (todos mencionados por Olga de Sá para comparação com G.H.). Um dos ineditismos alcançados pela obra de 1964, que, visando o tema da arte nesse romance, contribui para argumentar sobre a necessidade e a consequente consciência de escritora que G.H. conquista na obra: ao passar de sua arte escultórica para a escrita, a fim de compartilhar sua experiência com um leitor (simbolizado pela mão decepada), tentando ordenar o caos de sua experiência em uma nova organização necessária. ${ }^{173}$

\footnotetext{
170 SÁ, Olga de. A escritura de Clarice Lispector. Petrópolis: Vozes; PUC-SP, 1993.

171 Ibidem, p. 130.

172 Ibidem, p. 152.

173 Aqui, proponho para contemplação e reflexão um trecho do "O direito à literatura", no qual Antonio Candido reflete sobre o poder especial da arte da palavra:
}

A produção literária tira as palavras do nada e as dispõe como todo articulado. Este é o primeiro nível humanizador, ao contrário do que geralmente se pensa. A organização da palavra comunica-se ao nosso espírito e o leva, primeiro, a se organizar; em seguida, a organizar o mundo. (...)

Mas as palavras organizadas são mais do que a presença de um código: elas comunicam sempre alguma coisa, que nos toca porque obedece a certa ordem. Quando recebemos o impacto de uma produção literária, oral ou escrita, ele é devido à fusão inextricável da mensagem com a sua organização. Quando digo que um texto me impressiona, quero dizer que ele impressiona porque a sua possibilidade de impressionar foi determinada pela ordenação recebida de quem o produziu. Em palavras usuais, o conteúdo só atua por causa da forma, e a forma traz em si, virtualmente, uma capacidade de humanizar devido à coerência mental que pressupõe e que sugere. $\mathrm{O}$ caos originário, isto é, o material bruto a partir do qual o produtor escolheu uma forma, se torna ordem; por isso, o meu caos interior também se ordena e a mensagem pode atuar. Toda obra literária pressupõe esta superação do caos, determinada por um arranjo especial das palavras e fazendo uma proposta de sentido. (CANDIDO, 1995, p. 177-178) 
Outro estudo essencial dessa obra é o de Benedito Nunes, principalmente em $O$ drama da linguagem: Uma leitura de Clarice Lispector. Nunes, como Sá, aponta o caráter paradoxal da paixão de G.H.: "a perda de G.H. transformar-se-á em ganho. Pela negação de si mesma, ela alcançará a sua verdadeira e própria realidade" ${ }^{174}$. Mas o destaque dessa análise fica justamente para o que Nunes chama de drama da linguagem:

Entre o ser e o dizer abre-se um hiato, uma distância permanente, que a própria linguagem assinala e na qual ela se move. O regime reflexivo forçado, que nos revelaram aquelas frases anteriormente destacadas, é o indício do dilaceramento da narradora, presa à identidade impessoal do ser na visão silenciosa que a solidariza com as coisas, e obrigada a aprofundar, pela narrativa, a despeito de sua busca do inexpressivo, a distância entre ser e dizer, entre a imanência e a transcendência, entre a realidade e a linguagem. Essa direção da narrativa, discurso transversal ao discurso parateológico, segue o curso da vida mística. ${ }^{175}$

\section{Ainda:}

Em A paixão segundo G.H. a narração caminha, por assim dizer, à contracorrente da experiência narrada. É o paradoxo egológico desse romance: a narração que acompanha o processo de desapossamento do eu, e que tende a anular-se juntamente com este, constitui o ato desse mesmo eu, que somente pela narração consegue reconquistar-se. Por isso mesmo, extrema-se aqui o drama da linguagem: a narrativa é o espaço agônico do sujeito e do sentido - espaço onde ele erra, isto é, onde ele se busca -, o deserto em que se perde e se reencontra para de novo perder-se, juntamente com o sentido daquilo que narra, num processo em círculo, que termina para recomeçar, e cujo início não pode ser mais que um retorno. ${ }^{176}$

Novamente o elemento do desapossamento da humanização do eu aliado à linguagem: paradoxalmente, o processo de anulamento de si passa pela necessidade da narrativa, "onde ele erra, onde ele se busca", nesse círculo aparentemente interminável e inevitável para a definição da nova G.H.. Não cessar essa experiência, caminhar sempre junto com ela, é o que poderá fazer com que haja não só um novo sujeito no final da narrativa, mas também uma nova artista, propondo que a trajetória da personagem possa ser muito mais do que uma experiência com o outro e passe a constituir, também, uma travessia de formação artística, como se tentará defender adiante.

Outro aspecto trazido por Nunes, em seu estudo "O mundo imaginário de Clarice Lispector"177, cujas inferências se entroncam à questão da travessia do artista, é a comparação

\footnotetext{
174 NUNES, Benedito. "O itinerário místico de G.H.". In: O drama da linguagem - uma leitura de Clarice Lispector. São Paulo: Ática, 1995, p, 60.

175 Ibidem, p. 74-75.

176 Ibidem, p. 76.

177 NUNES, Benedito. "O mundo imaginário de Clarice Lispector". In: O dorso do tigre. São Paulo: Editora 34, 2009, p. 93-134.
} 
do nojo clariceano com a náusea sartreana. Ao invés de aproximar esses dois, o crítico traça diferenças entre eles, estabelecendo, assim, a originalidade da autora brasileira que, com o romance $A$ paixão segundo G.H., foi tão comparada ao autor francês:

O aprofundamento da náusea, como revelação do Ser e via mística de união com a sua inexpressável realidade, é a nota marcante de A paixão segundo G.H.. Narra-se aí uma experiência espiritual contraditória, em que o sacrifício e o sacrilégio se confundem, a redenção significando a anulação da personalidade e o amor a entrega do Eu a potências cósmicas indiferenciadas, não éticas, que têm um lado sombrio e diabólico, infernal, e outro luminoso e divino.

Já podemos discernir, nesse ponto, a modificação que a experiência sartriana da náusea sofreu na obra de Clarice Lispector. A partir dessa experiência, Jean-Paul Sartre conferiu aos seus personagens uma liberdade fundamental. Justamente porque a náusea revela o Absurdo, é preciso criar o sentido que a existência não possui. Esse sentido, que deriva única e exclusivamente da liberdade, e é sustentado pelos nossos atos, impõe-se apesar da náusea e contra o Absurdo.

Para Clarice Lispector a náusea apossa-se da liberdade e a destrói. É um estado excepcional e passageiro que, para a romancista, se transforma numa via de acesso à existência imemorial do Ser sem nome, que as relações sociais, a cultura e o pensamento apenas recobrem. Interessa-lhe o outro lado da náusea: o reverso da experiência humana, ilimitado, caótico, originário. ${ }^{178}$

Apesar de, diferente de Sartre - que "conferiu aos seus personagens uma liberdade fundamental"-, Clarice fazer com que a náusea de G.H. destrua sua liberdade, uma outra liberdade lhe é dada. A liberdade do desprendimento sofrido com o mundo, com a sociedade, atendendo "ao apelo ancestral do Ser. É um apelo inumano, que intercepta qualquer socorro humano - amizade, amor ou piedade -, que desorganiza a pessoa no que ela tem de social"179. Uma nova identidade é dada à protagonista: "a identidade do Eu convencional foi trocada pela identidade real com a matéria da vida. Esse trânsito é sentido como desgaste, como perda irreparável da própria substância humana, que se abriu para conter a substância universal"180. Graças a essa perda, G.H. conquista com a experiência mística e infernal o "amor do neutro - da coisa a que se reduzem todas as coisas" ${ }^{181}$. Eis sua paixão, "a qual está na origem de todos os desejos e de todas as inquietações passionais, sem excetuar o amor do Absoluto, que a inquietação mística exprime" 182 .

Dessa experiência de desapossamento e de encontro com o neutro, que origina sua nova liberdade e identidade inumanas, surge uma nova G.H. e, possivelmente, também uma

\footnotetext{
178 Ibidem, p. 100.

179 Ibidem, p. 105.

180 Ibidem, p. 105.

181 Ibidem, p. 110.

182 Ibidem, p. 111.
} 
nova artista, como se tentará investigar adiante. A experiência do inferno a faz atravessar as camadas e camadas da sociedade, chegando ao desértico pré-histórico e pré-humano, impelindo-a a passar por um doloroso processo de desprendimento de sua vida anterior. É justamente esse fator que tanto Clarice, em "O artista perfeito", quanto Herbert Marcuse na sua teoria do Künstlerroman e outros críticos e estudiosos do tema do artista - como o Outsider, que será apontado na análise de G.H. - consideram como essencial para a formação desse sujeito. G.H. modifica-se como sujeito, podendo se modificar como artista; portanto, porque essa trajetória da náusea não poderia ser, também, uma travessia de desenvolvimento da subjetividade artística?

Yudith Rosenbaum, por sua vez, oferece ao leitor clariceano uma leitura psicanalítica de sua obra, focando nas modulações do mal na escrita da autora. Na narrativa de G.H., o elemento maligno surge graças às "facetas do unheimliche freudiano, ou seja, esse estrangeiro terrível dentro de nossa própria casa" ${ }^{183}$ :

"É que ali dentro de minha casa se alojara, a estrangeira, a inimiga indiferente". Assim G.H. refere-se à empregada Janair, duplo desse outro estranho que é a barata, habitante pré-histórico de seu quarto, templo sagrado dessa aventura em direção às próprias origens.

A repercussão dessa "infamiliaridade" da barata, condensação simbólica do inconsciente como lugar do Outro em nós, invade o cenário do conto e da psique de G.H. (...)

Como quer Freud no ensaio sobre "O Estranho" (1919), o elemento que amedronta aponta para o retorno do reprimido, sugerindo que algo conhecido e familiar deveria permanecer secreto mas veio à luz. É esse material sinistro e perturbador que move o romance $(\ldots) .{ }^{184}$

O que leva ao aprendizado de G.H.:

O ethos da paixão de G.H. (...) Trata-se de perder o poder fálico sobre o outro, desaprender um olhar viciado sobre as coisas, implodir um edifício bem arrumado e sucumbir ao domínio do desconhecido. Agora é a barata que engessa G.H., em seu instante de torpor e horror, impedindo-a de avançar e movimentar-se de novo na busca do refúgio e comodidade. A barata, na sua impersonalidade soberba, com sua força nadificante, quebra sadicamente $o$ invólucro da persona G.H. ${ }^{185}$

Tudo isso nessa forma incomum e inédita desse romance, onde

a palavra é expandida de forma a se aproximar por todos os lados daquilo que se quer expressar. A linguagem hesita, titubeia, comove-se, despe-se, indaga, sempre à procura do nome do ser. (...) aqui desdobram-se as frases (o capítulo se abre com a frase que termina o

\footnotetext{
${ }^{183}$ ROSENBAUM, Yudith. "O pathos da criação". Op. cit., p. 147.

${ }^{184}$ Ibidem, p. 147-148.

185 Ibidem, p. 149.
} 
anterior), repetem-se verbos e parágrafos. É evidente que a narração de G.H. ocorre quase no calor da hora, pouco depois de seu acontecimento; o leitor ainda sente as ressonâncias do impacto emocional na personagem, aturdida e desorganizada. Não há defesa que impeça a experiência de alastrar-se pelos capítulos numa reação em cadeia (...). ${ }^{186}$

Ainda:

Nas palavras da escultora G.H. (cuja arte é curiosamente dar forma ao que é bruto), esse desvelamento implica "ter passado pela experiência de desgastar pacientemente a matéria até gradativamente encontrar sua escultura imanente". Em síntese, o que vai se configurando é uma estética da depuração em busca do minério oculto; a linguagem, qual picareta na mina, golpeia a superfície endurecida da ganga bruta à procura de diamantes, que podem surgir quando menos se espera. ${ }^{187}$

Nesse trecho, a autora aproxima a forma de narrar à arte escultórica da protagonista. O desgaste da linguagem em busca do minério oculto parece imitar justamente o desgaste da matéria bruta pré-esculpida, a qual vai ganhando forma a partir da lapidação, do contato direto com as mãos do escultor, moldando-se, desmoldando-se, remoldando-se, até sua forma definitiva e final. Eis a configuração do romance; eis a arte da escultura em síntese.

Outro aspecto formal é apontado nessa obra crítica: as aberturas de capítulo que retomam o anterior, pela repetição da sua última frase, relembram Rosenbaum das "cantigas medievais, que construíam as estrofes sempre com o último verso da anterior, recurso conhecido como leixa-pren" ${ }^{188}$, cujo possível objetivo na obra de Clarice seria "estabelecer uma tal continuidade entre as partes, que não seja mais possível discriminar o início e o fim" ${ }^{189}$. Da mesma forma, seria possível pensar que, em uma escultura, os processos manuais de formação não são mostrados no resultado final, fazendo também com que haja uma continuidade aparentemente natural, certo caráter de desconhecimento e indiferenciação entre sua configuração no início, durante sua construção e no fim - uma vez que, ao observador da escultura, é dado apenas a obra de arte já concluída.

Rosenbaum também reflete sobre a pintura de Janair, outro elemento essencial para a reflexão sobre os procedimentos da arte e a problemática do artista:

Temos, então, uma alusão clara à arte primitiva do período paleolítico, caracterizada pelo gesto mágico do artista que, ao pintar um animal, aprisionava-o na realidade. Trata-se de acenar para a indiscriminação entre o mundo da mimesis, da representação, e o mundo da

\footnotetext{
186 Ibidem, p. 152-153.

187 Ibidem, p. 154.

188 Ibidem, p. 170.

189 Ibidem.
} 
realidade empírica, anulando a descontinuidade inevitável entre ambos. Aprofundemos um pouco mais essa noção a partir da definição de Arnold Hauser:

As pinturas faziam parte da técnica deste processo de magia; eram a "ratoeira" em que a caça havia de cair, ou a ratoeira com o animal já capturado. É que os desenhos constituíam simultaneamente a representação e a coisa representada; eram simultaneamente o desejo e a realização do desejo. O caçador e o pintor da era paleolítica supunham encontrar-se na posse do próprio objeto desde que possuíssem a sua imagem; julgavam adquirir poder sobre o objeto por intermédio da sua representação.

Portanto, a imagem é a coisa, a escrita é o real, anulando-se o intervalo e a distância inevitáveis ao ato de representar. ${ }^{190}$

Importante destacar a questão da posse identificada por Hauser, citado no trecho. Janair, a partir do desenho, poderia então demonstrar poder sobre G.H.? Essa seria uma possível surpresa da narradora: ela, que acreditava estar acima da empregada, tendo autoridade sobre ela, descobre-se representada pelo outro pertencente às classes desfavorecidas, e é justamente na arte que esse outro conquistaria poder e autoridade.

Por fim, dos muitos outros pontos que se pode destacar dessa obra de Rosenbaum, enfatizam-se, aqui, algumas de suas conclusões:

(...) o que vemos desdobrar-se aos nossos olhos escapa a uma única vertente interpretativa. Os planos de significados são múltiplos e poderíamos sinalizar alguns deles. Há o caminho do autoconhecimento, verdadeiro processo de análise já sugerido, que tolera o trânsito da experiência de morte e fragmentação para construir um ser pulsante e vivo; há, ainda, a metáfora da criação artística, muito próxima do processo analítico, em que a personagem se desfaz corpórea e psiquicamente, no momento criativo, destruindo seus alicerces valorativos, morais e linguísticos, para viver a experiência do horror e do limite do indizível; há também, e fundamentalmente, a representação da própria emergência e sabotagem do processo cultural como construção problemática e hesitante advinda da luta entre Eros e Thanatos, vivenciando-se a força desagregadora e anárquica da pulsão de morte e sua expressão sádica. Qual "Odisséia negativa", a travessia de G.H. se dá rumo à vida primária, momento inaugural ao qual se chega por uma anti-racionalidade, em tudo oposta à constituição de um sujeito psíquico organizado. ${ }^{191}$

Destacam-se os seguintes passos: o caminho do autoconhecimento, a metáfora da criação artística e a descoberta da construção problemática da cultura no indivíduo. $\mathrm{O}$ primeiro vem graças ao último: o autoconhecimento é possível após a perda da "terceira perna" e da consciência acerca da prisão civilizatória. Já a metáfora da criação artística pode ser vista nas duas artes de G.H.: a escrita, a qual, sendo desenvolvida logo após a experiência,

\footnotetext{
190 Ibidem, p. 159.

191 Ibidem, p. 171-172.
} 
luta para existir, em um inicial processo de adiamento da narrativa, seguida de uma escrita que, espiralada, retoma a si mesma para poder progredir; e a escultura, que, como a escrita de G.H., molda o bruto, fazendo e desfazendo formas, até advir o objeto pronto.

Emília Amaral, em O leitor segundo G.H., persegue a relação entre eu (G.H.) e tu (leitor) na obra. Além de retomar a imagem do uroboro, a serpente que morde a própria cauda, revelando a ambiguidade estrutural da narrativa -

A intensidade, expressa por meio da repetição, retarda o andamento do discurso, num retorno ao mesmo que nunca é exatamente o mesmo. Nesse sentido, pode-se falar que o texto desenvolve-se numa espécie de progressão em escalas, por meio de um procedimento ambíguo em que avançar é ao mesmo tempo - mas não só - retomar, em que se movimentar em direção a uma continuidade simultaneamente é se autofecundar, numa estrutura que oscila entre o círculo, o pêndulo, o mesmo, e o espiral, o avanço efetivo, o outro.

Daí as frases que terminam cada capítulo iniciarem o posterior, terminando uma escala, uma camada textual e ao mesmo tempo iniciando outra, que é e simultaneamente não é a mesma, pois a ela sempre se acrescenta algo. Daí os seis travessões instauradores do espaço de interlocução na abertura reaparecerem na última página, anunciando ao leitor não um desfecho, uma conclusão, mas a possibilidade de voltar ao começo do livro, ao tempo das origens ancestrais rememoradas por G.H. e assim re-ler, re-ver, re-conhecer o incognoscível, num exercício de volta que também é avanço, pois se a escrita-uroboro fracassa em sua tentativa de (des)velamento do Ser, este mesmo fracasso a converte em Ser que jamais se (des)vela totalmente (...). ${ }^{192}$

-, Amaral também nota como a máxima que aparece no relato da protagonista, "uma forma que é feita de suas formas opostas" (quando G.H. faz triângulos com as bolinhas de pão), "sintetiza o sentido e a direção da travessia de G.H., tanto no ato de ver quanto no de relatá$10^{193}$. Em vista disso:

essa realidade indizível, que no entanto passional e apaixonadamente ela não abre mão de dizer, só pode ser expressa de modo negativo, ou seja, por meio daquilo que ela não é: os sentimentos, os atributos, os valores humanos e sobretudo a linguagem e a forma. Assim, o processo narrativo faz-se pelo avesso, configurando uma espécie de anti-romance, que, por sua vez, parece pedir um anti-leitor: como é constituído, ao longo da obra, o leitor segundo G.H.? ${ }^{194}$

Essa pergunta sobre a construção do leitor de G.H. é replicada adiante por Amaral: ele é atraído exatamente pela situação-limite que G.H. experiencia, buscando, junto com a protagonista, um sentido - e constatando com ela como, de fato, pode haver uma ausência de explicação e de significado para tudo o que ela vivera:

\footnotetext{
192 AMARAL, Emília. O leitor segundo G.H.. São Paulo: Ateliê Editorial, 2005, p. 86-87.

193 Ibidem, p. 45.

${ }^{194}$ Ibidem, p. 46.
} 
o encantamento, a sedução do leitor em PSGH ocorre na medida em que, ao longo da leitura, ele vai se deixando contaminar pela situação-limite vivenciada pela protagonista. Trata-se de uma situação designada como limite por ser indizível, intraduzível pela linguagem e portanto intransitiva. Mesmo assim, ou exatamente por isso, é ela a força motriz que gera o desejo do livro que vai se escrevendo, o ímã que magnetiza o leitor, o qual vai sendo perversamente aliciado em sua busca de sentido por meio de um reiterada constatação de falta e consequentemente de possibilidade de sentido. ${ }^{195}$

O leitor, simbolizado pela mão decepada, aceita o pacto narrativo e caminha com G.H. pelo seu percurso da paixão. Dando as mãos, leitor e narradora passam juntos por toda a travessia de G.H.: o quarto da empregada, a pintura de Janair, a barata e seu esmagamento, a procura de um significado dessa experiência. G.H. escreve pois precisa compartilhar com alguém tudo o que ocorrera naquele dia; e, focando nesse alguém, no outro misterioso que estaria do outro lado das palavras, ela descreve vividamente o desenho pré-histórico, a exempregada, a barata ancestral, a fim de que o leitor passe pelo que ela passou. É aqui, como se argumentará adiante, que o recurso da écfrase parece ter lugar.

Dessa forma, o leitor tem papel fundamental para G.H.: ao idealizá-lo, ela parece admitir uma identidade de uma nova artista, uma escritora. G.H. passa da arte da escultura para a arte da palavra, mas a especificidade da primeira - visualidade e tridimensionalidade, principalmente - não deixará de estar presente em sua obra verbal, como se verá na análise do romance.

Para além das questões artísticas na obra, Solange Ribeiro de Oliveira escreve sobre o que ela chama de "leitura ideológica" de A paixão segundo G.H. ${ }^{196}$. Originalmente publicado em $1985^{197}$, esse ensaio foca justamente na questão social encontrada nessa obra clariceana: a luta de classes simbolizada pela relação entre G.H. e Janair (e a barata, consequentemente, já que ela é o duplo da empregada, fato que Oliveira também retoma). Oliveira nota como G.H. "se define como 'a mulher de propriedade' (...) quando alude ao elegante apartamento de cobertura em que reside no Rio de Janeiro"198, e como o prédio simboliza essa pirâmide de classes: "Do alto do prédio, 'como se estivesse no pico de uma montanha', a narradora contempla o 'precipício' de sua classe, o mundo das classes

\footnotetext{
195 Ibidem, p. 86.

196 OLIVEIRA, Solange Ribeiro de. "A paixão segundo G.H.: uma leitura ideológica". In: NUNES, Benedito (org). A Paixão segundo G.H.: edição crítica. Madrid; Paris; México; Buenos Aires; São Paulo; Rio de Janeiro; Lima: ALLCA XX, 1996, p. 342-349.

197 C.f.: OLIVEIRA, Solange Ribeiro de. A barata e a crisálida: o romance de Clarice Lispector. Rio de Janeiro: José Olympio, 1985.

198 Ibidem, p. 343.
} 
trabalhadoras: 'Olhei para baixo; treze andares caíam do edifício (...) O bojo do meu edifício era como uma usina"199.

Segundo Oliveira, o ódio de G.H., que a faz querer matar algo no quarto expurgando esse desejo, por fim, na barata -, é, portanto, o ódio de classes. E é a manifestação artística de Janair que permite o embate inicial entre eu e outro de classes diferentes:

O que irrita G.H. acima de tudo é que a censura muda que lê no desenho fora expressada por alguém de uma classe social inferior (...).

Esse ódio impessoal é, evidentemente, o ódio do opressor pelo oprimido, o ódio entre a que nunca teve privilégios e a que temia perder os que sempre tivera. (...)

No desenho - ou na mente de G.H. - patroa e empregada agora se defrontam pela primeira vez e seu encontro é de puro ódio. G.H. usa diversas vezes o demonstrativo "aquela" ("aquela empregada"), com sua conotação emocional de desprezo e ódio. ${ }^{200}$

Em um embate entre defender os privilégios de sua classe e ceder à aceitação da barata, espécie de metáfora para o reconhecimento da injustiça social que sofre justamente esse Outro desconhecido e até então ignorado, G.H. por fim escolhe se identificar totalmente com o inseto ao ingeri-lo, renunciando, como notou Oliveira, à ideologia dominante que a antiga G.H. seguia fidedignamente. Conforme se tentará defender à frente, essa renúncia pode ser exatamente o que faltava a G.H. para ela se tornar uma artista como os outros ("perfeitos") de sua categoria: dissociada dos mandos civilizatórios.

A última leitura que aqui se quer destacar é também de Oliveira. Em Literatura e artes plásticas: o Künstlerroman na ficção contemporânea, Oliveira evidencia o tema da arte em G.H., principalmente a pintura do quarto de Janair, e destaca sobre a protagonista:

A obsessão de G.H. pela forma, especialmente a geométrica, reminiscente do Cubismo, reaparece em outras afirmações da escultora. Ela se diz afeita à "escultura esporádica" de uma "arte diletante". Parece trabalhar pouco, em termos de produção de obras concretas. Nem uma vez menciona uma escultura sua. Obcecada pela arte, G.H. parece não ter uma obra. Isso se explica por um fato paradoxal: sua obra não exibe coisa alguma porque abrange tudo. A escultura de G.H. tem como objeto nada menos que toda a realidade, ou antes, sua visão direta, "inocente", não mediada por qualquer interpretação redutora e deformante. $\mathrm{O}$ trabalho de G.H. consiste precisamente em desconstruir o arcabouço ideológico onde se encaixa a experiência da história ocidental. Nisso consiste o que ela chama de "desgastar pacientemente a matéria", para encontrar "a escultura imanente". ${ }^{201}$

\footnotetext{
199 Ibidem.

200 Ibidem, p. 345.

201 OLIVEIRA, Solange Ribeiro de. Literatura e artes plásticas: o Künstlerroman na ficção contemporânea. Ouro Preto: UFOP, 1993, p. 120.
} 
A leitura feita por Oliveira conclui que a experiência de G.H. como escultora pode ser lida como uma metáfora. O labor como artista visual seria não o de construir estátuas, mas o de talhar as camadas arqueológicas que escondem o contemporâneo funcionamento social, descobrindo como a máquina do mundo operaria. Análise interessante, mas que, para a interpretação que se quer fazer aqui, da narrativa de G.H. como uma possível trajetória da formação do artista, não se poderia excluir o fato da personagem ser, realmente, uma artista - mais propriamente, uma escultora, mesmo dizendo-se amadora e trabalhando esporadicamente.

Além disso, e encerrando-se finalmente esse percurso de elucidar algumas leituras fundamentais, em face da investigação do tema da arte e da formação do artista, Oliveira vê no mural deixado pela antiga empregada, "em alusões rápidas mas sugestivas, a história da arte ocidental, em alguns de seus momentos culminantes": a arte rupestre, a arte egípcia, a arte grega, a bizantina, a renascentista, o Barroco e o Cubismo. O trecho em que Oliveira explica a relação dessas artes com a narrativa clariceana será explorado adiante, durante o percurso de análise e interpretação da obra.

Enfim, há que se dizer que o percurso pela fortuna crítica destacou as leituras cujas abordagens tocam, em alguma medida, os pontos nodais do recorte proposto. Houve, é claro, obras igualmente importantes que não foram destacadas especificamente aqui - como outros textos da edição crítica de A paixão segundo G.H., organizada por Benedito Nunes; a obra de Carlos Mendes de Sousa, Clarice Lispector: Figuras da escrita; o estudo de Daniela Kahn em A via crucis do outro: identidade e alteridade em Clarice Lispector; a dissertação de Mariângela Alonso "Instantes líricos de revelação: a narrativa poética em A paixão segundo G..H."; dentre muitos e muitos outros textos -, seja porque retomam, de certa forma, o que já fora dito por esses outros autores resumidos, seja porque o objetivo desta seção é apenas tentar resumir aqueles textos que, para a leitura do tema que aqui se persegue, demonstraram visões fundamentais, consagradas e até inéditas sobre a obra em questão. 


\title{
4.2 Desvendando G.H.: a mulher e a escultora
}

\begin{abstract}
Ajo como o que se chama de pessoa realizada. Ter feito escultura durante um tempo indeterminado e intermitente também me dava um passado e um presente que fazia com que os outros me situassem: a mim se referem como a alguém que faz esculturas que não seriam más se tivesse havido menos amadorismo. Para uma mulher essa reputação é socialmente muito, e situou-me, tanto para os outros como para mim mesma, numa zona que socialmente fica entre mulher e homem. O que me deixava muito mais livre para ser mulher, já que eu não me ocupava formalmente em sê-lo. ${ }^{202}$
\end{abstract}

Assim G.H. caracteriza a si mesma logo no início da narrativa: uma escultora e uma pessoa realizada. A posição como tal artista dava a ela um lugar social, situado entre mulher e homem, apesar de seu amadorismo. No entanto, esse mesmo amadorismo pode, também, ser um ato de liberdade, uma vez que ela não precisaria se "ocupar formalmente" com essa profissão. ${ }^{203}$

G.H. confessa que seu trabalho é, de fato, intermitente e, por isso, não profissional, sendo esse aspecto reconhecido pelos outros e tido como uma espécie de defeito ("não seriam más se tivesse havido menos amadorismo"). Mesmo assim, ela havia conseguido uma nova posição como mulher na sociedade, estando situada em um limiar: o da mulher independente cujo papel até então era novo em uma sociedade ainda patriarcal, fugindo, assim, da vida tradicional que as mulheres possuíam principalmente até o século $\mathrm{XX}$, quando essa mudança ocorre mais efetivamente. Dessa forma, é interessante notar que ao mesmo tempo em que se define, G.H. parece definir toda uma classe de mulheres trabalhadoras de classe média que começaram a surgir em sua época. E esse papel é conseguido graças, possivelmente, à sua escultura amadora.

Além disso, a escultura de G.H. também parece fazê-la pertencer a uma classe social mais elevada, uma vez que ela possui seu próprio apartamento em uma cobertura, morando sozinha nele, identificando-se, em um primeiro momento da narrativa (sua vida préexperiência com a barata), com esse estilo de vida luxuoso e altivo:

\footnotetext{
${ }^{202}$ LISPECTOR, Clarice. A paixão segundo G. H.. Rio de Janeiro: Rocco, 2009, p. 25. Para facilitar, daqui em diante, será utilizada para a referência a essa obra a sigla PSGH.

${ }^{203}$ De modo análogo, Clarice Lispector, em sua entrevista para Júlio Lerner, afirma que ela não se considera uma escritora, pois, em suas palavras:

Eu não sou profissional, eu só escrevo quando eu quero. Eu sou uma amadora e faço questão de continuar a ser amadora. Profissional é aquele que tem uma obrigação consigo mesmo, de escrever, ou então com o outro, em relação ao outro. Agora eu faço questão de não ser uma profissional, para manter minha liberdade.
}

Entrevista disponível em: $<$ https://www.youtube.com/watch?v=ohHP112EVnU $>$. 
O apartamento me reflete. É no último andar, o que é considerado uma elegância. Pessoas de meu ambiente procuram morar na chamada "cobertura". É bem mais que uma elegância. É um verdadeiro prazer: de lá domina-se uma cidade. Quando essa elegância se vulgarizar, eu, sem sequer saber por que, me mudarei para outra elegância? Talvez. ${ }^{204}$

Outra revelação que ela faz de sua vida, mais à frente da obra, é um suposto aborto que ela teria feito, o que também a posiciona fora das normas impostas pela sociedade ao sexo feminino, já que G.H. escolhe realmente não ter filhos:

- Lembrei-me de mim mesma andando pelas ruas ao saber que faria o aborto, doutor, eu que de filho só conhecia e só conheceria que ia fazer um aborto. Mas eu pelo menos estava conhecendo a gravidez. Pelas ruas sentia dentro de mim o filho que ainda não se mexia, enquanto parava olhando nas vitrines os manequins de cera sorridentes. E quando entrara no restaurante e comera, os poros de um filho devoravam como uma boca de peixe à espera. Quando eu caminhava, quando eu caminhava eu o carregava. ${ }^{205}$

Dessa maneira, G.H. parece já estar incluída no que Virginia Woolf colocou como pontos essenciais da mulher para ela se tornar artista: ter tempo livre (não ter filhos, não se casar e, portanto, dispor de tempo extra, não obedecendo, assim, aos mandos sociais à mulher), dinheiro (a independência financeira parece alcançada, possivelmente com seu trabalho como escultora), e um quarto só para si $^{206}$ (no caso, todo um apartamento de sua posse). É interessante pensar dessa forma ao se comparar G.H. com a primeira protagonista de Clarice - que parece buscar seu lugar no mundo e, talvez, na arte: enquanto Joana, protagonista do primeiro romance clariceano, Perto do coração selvagem, parecia procurar se livrar de tudo que a mantinha em uma vida cercada pelas obrigações dadas à mulher pela sociedade (separando-se do marido, arrumando um amante e conhecendo a amante do exmarido, Lídia, que era o modelo de mulher para a sociedade - cuidava do lar, do marido e, provavelmente no futuro, do filho que estava esperando) para poder seguir com a arte da palavra que a perseguia desde a infância, G.H. já está, aparentemente, em um caminho mais livre e independente. Nesse seu caminho constituído por uma maior liberdade, é interessante, também, notar como o espaço doméstico de G.H. não é mais opressor, ou seja, não simboliza

\footnotetext{
204 PSGH, p. 29.

205 PSGH, p. 90.

206 WOOLF, Virginia. "Mulheres e ficção". São Paulo: Cosac Naify, 2014, p. 283. As mesmas ideias são apresentadas, também, em seu discurso que deu origem à obra Um teto todo seu.
} 
mais as regras sociais impostas à mulher. Diferentemente do que escreveu Virginia Woolf ${ }^{207}$, como já apontado anteriormente, toda a experiência iniciática e de (trans)formação artística de G.H. ocorre em seu apartamento - como se tentará desenvolver mais adiante. O espaço doméstico é, aqui, também o espaço da artista moderna: agora independente, ela pode experienciar a si mesma e desenvolver-se artisticamente no âmbito privado da casa - ou, no caso, do apartamento próprio -, uma vez que este não é mais símbolo da restrição social do sexo feminino ao cuidado com o marido e com os filhos.

No entanto, mesmo com essa certa liberdade, G.H. passará por uma experiência arrebatadora: primeiro ao ver o desenho de Janair, sua ex-empregada; depois ao ver a barata saindo do guarda-roupa, quando decide arrumar o quarto da empregada. É daí que surge todo o relato da obra e G.H. passa, assim, da sua arte original - a escultura, arte do espaço - para a escrita - a arte do tempo, sua narrativa verbal inventando um leitor -, misturando-as de certa forma durante a obra, como se verá na análise adiante. Parece ser dessa maneira que as duas artes se encontram no romance: pode-se notar que há de alguma forma a influência da arte visual na arte verbal de G.H.. Na verdade, a protagonista recorre às palavras uma vez que, segundo ela, seria impossível seguir sua vida após a experiência sem contá-la a alguém:

Já que tenho de salvar o dia de amanhã, já que tenho que ter uma forma porque não sinto força de ficar desorganizada, já que fatalmente precisarei enquadrar a monstruosa carne infinita e cortá-la em pedaços assimiláveis pelo tamanho de minha boca e pelo tamanho da visão de meus olhos, já que fatalmente sucumbirei à necessidade de forma que vem de meu pavor de ficar delimitada - então que pelo menos eu tenha a coragem de deixar que essa forma se forme sozinha como uma crosta que por si mesma endurece, a nebulosa de fogo que se esfria em terra. E que eu tenha a grande coragem de resistir à tentação de inventar uma forma.

Esse esforço que farei agora por deixar subir à tona um sentido, qualquer que seja, esse esforço seria facilitado se eu fingisse escrever para alguém. ${ }^{208}$

A atividade direta com as mãos que constitui o fazer escultórico parece, portanto, não ser mais suficiente para contar sua experiência e, assim, atravessá-la novamente. Apesar de, para Clarice, as artes visuais estarem aparentemente em um patamar superior ao verbal (segundo testemunham as crônicas, o que não quer dizer que as declarações estejam livres de ambiguidades), a escrita será, de fato, a maldição que salva G.H., socorrendo-a após o episódio. Ademais, o desejo pela organização das experiências vividas, dando uma forma a elas, também parece se mostrar na arte da escultura - e na narrativa de G.H. quando, por

207 Conforme elucidado na segunda parte deste trabalho. Retomando, em resumo: Woolf demandava a conquista do espaço público pela mulher, para ela, assim, tornar-se artista, já que a casa simbolizava sua "prisão" pensando nos moldes patriarcais que a atribuíam as tarefas exclusivas com o lar.

208 PSGH, p. 13, grifos meus. 
exemplo, antes de adentrar no quarto da empregada, ela está na mesa fazendo bolinhas de pão:

Da mesa onde me atardava porque tinha tempo, eu olhava em torno enquanto os dedos arredondavam o miolo de pão. O mundo era um lugar. Que me servia para viver: no mundo eu podia colar uma bolinha de miolo na outra, bastava justapô-las, e, sem mesmo forçar, bastava pressioná-las o suficiente para que uma superfície se unisse a outra superfície, e assim com prazer eu ia formando uma pirâmide curiosa que me satisfazia: um triângulo reto feito de formas redondas, uma forma que é feita de suas formas opostas. Se isso me tinha um sentido, o miolo de pão e meus dedos provavelmente sabiam. ${ }^{209}$

A forma feita com as bolinhas de pão, organizando seus miolos e justapondo-os para conceber uma outra figura, também parece se assemelhar, de alguma maneira, ao feito do escultor, que trabalha com o concreto, talhando-o e transformando-o em uma figura diferente da original. ${ }^{210}$ Enquanto em seu mundo prévio a escultora poderia simplesmente colar essas bolinhas sem esforço, realizando sua escultura de maneira provavelmente descomplicada, organizando facilmente seu mundo, após a experiência, G.H. precisará de uma força maior para poder compartilhar o que vivera.

A escultura, dessa forma, contrapondo-se à escrita, parece ter servido para a protagonista justamente como uma espécie de prenúncio da experiência pela qual ela passaria - graças não só à organização que ela dá a uma forma, mas, também, ao contato mais direto que se pode ter com a matéria esculpida e, portanto, com o outro:

Quanto à minha chamada vida íntima, talvez também tenha sido a escultura esporádica o que lhe deu um leve tom de pré-clímax - talvez por causa do uso de um certo tipo de atenção a que mesmo a arte diletante obriga. Ou por ter passado pela experiência de desgastar pacientemente a matéria até gradativamente encontrar sua escultura imanente; ou

\footnotetext{
209 PSGH, p. 28-29.

210 Aqui, é importante retomar, sem querer reduzir a obra aos meros símbolos, a simbologia do triângulo e do círculo: o círculo representa, dentre outros, a totalidade, a eternidade e a unidade, além da perfeição. O triângulo por sua vez, também pode representar a perfeição, que, na tradição cristã, leva o nome de Santíssima Trindade. A junção desses dois símbolos aparece em outro conto da literatura brasileira: "A hora e a vez de Augusto Matraga", de Guimarães Rosa. Como já explicitado por Walnice Correia Galvão, no conto o círculo representa justamente a estrutura circular da narrativa de Matraga; já o triângulo faz parte da simbologia do número três, que permeia a vida do personagem. De forma semelhante, pode-se retomar a estrutura circular (ou espiral) também presente na narrativa de G.H., bem como o triângulo pode se referir às "três pernas" da personagem, que ainda a sustentavam nesse momento da narrativa. Sobre isso, ver a referência: ALONSO, Mariângela. Instantes líricos de revelação: a narrativa poética em A paixão segundo G.H. 2007. Dissertação (Mestrado em Estudos Literários). Faculdade de Ciências e Letras, Universidade Estadual de São Paulo, Araraquara, p. 35. Ainda conforme essa mesma referência de Mariângela Alonso:
}

O enunciado de G.H. nos remete ainda ao olho inserido no triângulo, o qual também faz parte dos símbolos maçônicos. Para a maçonaria este olho "representa a Divina vigilância, que observa e registra os atos do ser humano" (CAMINO, 1990, p. 449). Num sentido esotérico seria o "Terceiro Olho" ou “Terceira Visão", uma espécie de visão espiritual, diferentemente do órgão do ser humano. 
por ter tido, através ainda da escultura, a objetividade forçada de lidar com aquilo que já não era eu.

Tudo isso me deu o leve tom de pré-clímax de quem sabe que, auscultando os objetos, algo desses objetos virá que me será dado e por sua vez dado de volta aos objetos. Talvez tenha sido esse tom de pré-clímax o que eu via na sorridente fotografia mal-assombrada de um rosto cuja palavra é um silêncio inexpressivo, todos os retratos de pessoas são um retrato de Mona Lisa. ${ }^{211}$

Um "pré-clímax": para isso the servira sua arte. Uma preparação para o que ela encontraria naquele dia de faxina pelo quarto da empregada: lidar de forma mais sensível com o outro, com Janair, seu desenho e a barata, enfrentando, inclusive, o de-dentro do inseto, aquilo que é de fato imanente a ele, tornando-o algo que se amalgama a si mesma quando decide ingeri-lo.

Além disso, a escultura parece ajudá-la, inclusive, a visualizar seu leitor:

Enquanto escrever e falar vou ter que fingir que alguém está segurando a minha mão.

Oh pelo menos no começo, só no começo. Logo que puder dispensá-la, irei sozinha. Por enquanto preciso segurar esta tua mão - mesmo que não consiga inventar teu rosto e teus olhos e tua boca. Mas embora decepada, esta mão não me assusta. A invenção dela vem de tal ideia de amor como se a mão estivesse realmente ligada a um corpo que, se não vejo, é por incapacidade de amar mais. Não estou à altura de imaginar uma pessoa inteira porque não sou uma pessoa inteira. E como imaginar um rosto se não sei de que expressão de rosto preciso? Logo que puder dispensar tua mão quente, irei sozinha e com horror. ${ }^{212}$

A invenção da mão decepada do corpo parece, de alguma forma, ser uma espécie de escultura construída para que ela possa segurar e caminhar juntamente em seu relato. Ao visualizar (e esculpir, mesmo apenas com as palavras) a imagem dessa mão, G.H. poderia, enfim, começar a narrar seu horror, fingindo segurá-la e fingindo, portanto, que essa mão fosse algum objeto provavelmente tridimensional, para que esse ato de juntar as palmas seja, assim, efetivo. ${ }^{213}$ A mão não será a única escultura feita por G.H. no âmbito verbal. Mais à

\footnotetext{
211 PSGH, p. 25-26, grifos meus.

212 PSGH, p. 16-17.

213 A invenção dessa mão decepada e desconhecida pode lembrar, de certa forma, uma das esculturas de Rodin em que o artista retrata mãos: La Cathédrale (1908) - imagem inserida nos anexos. Nessa obra, as duas mãos que se entrelaçam, em um possível sinal de apoio e suporte uma à outra, podem auxiliar na reflexão sobre a mão do leitor, inventada por G.H., e a própria mão desta personagem, uma vez que o leitor, ao adentrar em sua história, aceita o pacto de dar as mãos à narradora para que ela possa, enfim, contar sua experiência. Diferentemente de outras das muitas esculturas de Auguste Rodin em que são retratadas mãos, essa, em especial, parece estar em movimento: no instante em que a escultura se apresenta ao apreciador, as duas mãos parecem estar se entrelaçando naquele exato momento. Ainda, essas duas mãos parecem estar, também, em posição de igualdade: elas se afiguram do mesmo tamanho, com uma curvada sobre a outra, e ambas aparentam ceder ao movimento retratado. Tal qual na obra clariceana em questão, narradora e leitor também são, de certa forma, iguais perante a narrativa, uma vez que há, como nota Emília Amaral, uma "inversão de papéis": a suposta superioridade do narrador perante o leitor - uma vez que, normalmente, é o primeiro quem detém e, portanto, conta a história ao segundo - apresenta-se quebrada, já que G.H., por diversas vezes no início do livro, adia sua
} 
frente, uma outra figura aparecerá, sendo construída de forma mais completa: a barata, como se mostrará adiante.

Além de descrever a si mesma (como mulher e escultora) e de inventar a condição para sua narrativa (o leitor, representado pela mão), G.H. também se prepara e, consequentemente, prepara o leitor para seu intuito narrativo:

Quero saber o que mais, ao perder, eu ganhei. Por enquanto não sei: só ao me reviver é que vou viver.

Mas como me reviver? Se não tenho uma palavra natural a dizer. Terei que fazer a palavra como se fosse criar o que me aconteceu?

Vou criar o que me aconteceu. Só porque viver não é relatável. Viver não é vivível. Terei que criar sobre a vida. E sem mentir. Criar sim, mentir não. Criar não é imaginação, é correr o grande risco de se ter a realidade. Entender é uma criação, meu único modo. Precisarei com esforço traduzir sinais de telégrafo - traduzir o desconhecido para uma língua que desconheço, e sem sequer entender para que valem os sinais. Falarei nessa linguagem sonâmbula que se eu estivesse acordada não seria linguagem.

Até criar a verdade do que me aconteceu. Ah, será mais um grafismo que uma escrita, pois tento mais uma reprodução do que uma expressão. Cada vez preciso menos me exprimir.

Também isto perdi? Não, mesmo quando eu fazia esculturas eu já tentava apenas reproduzir, e apenas com as mãos. ${ }^{214}$

Cabe notar, nesse trecho, as contradições entre reviver e viver e, também, entre os termos criar, mentir e verdade. Primeiramente, a narradora afirma que, após sua experiência, ela só vai poder viver se conseguir reviver. Reviver, aqui, pode ter duas acepções: a primeira, que ela deveria nascer novamente após o acontecido, começar tudo a partir de um ponto zero - sem a "terceira perna" que a sustentava e a guiava; a segunda, por sua vez, pode significar recordar o acontecido por meio do depoimento de sua escrita - o que ela tenta incessantemente produzir com sua narrativa. Esse reviver será construído na narrativa a partir de um criar, pois sua experiência não é relatável. Porém, importante notar que criar - palavra que se inclui no campo semântico da arte e do artista - e mentir são coisas diferentes para a protagonista: criar é tentar evocar a realidade para o leitor também conseguir experimentar o que ela viveu - no seu caso, ela tentará criar pelo relato; mentir se aproxima da imaginação - outra palavra que também pode ser inserida no campo semântico da arte -, a qual permite ao homem produzir pensamentos e reflexões que não estão propriamente na realidade vivida. Dessa forma, é possível depreender que G.H. difere a criação da imaginação. Segundo sua concepção, ela seria, no caso, uma artista que cria, ou seja, que busca trabalhar com a

narração, por não saber como organizá-la e contá-la. Para isso, ela vê a necessidade de inventar um leitor, cuja presença seria como um auxílio durante a construção do relato de sua vivência horripilante, ou "uma alteridade em que se possa refletir, que de algum modo seja capaz de espelhá-la [a escritora]" (AMARAL, 2005, p. 27).

${ }^{214}$ PSGH, p. 19. 
recriação mais verídica da realidade pela arte, como escultora (e, agora, escritora); ao contrário da arte que utiliza da imaginação e, assim, trabalha com questões fantasiosas que não se encontrariam no plano da verdade, afastando o artista da sua realidade - que, no caso de G.H., é a sua maior ambição: contar exatamente o que lhe ocorrera. ${ }^{215}$ Esse é um dos argumentos que a protagonista utiliza para tentar dar ao seu leitor uma sensação de autenticidade da experiência - tentativa, essa, que constitui um esforço contínuo de G.H. durante todo o seu percurso, tentando compartilhar verdadeiramente a sua experiência.

Ainda, a oposição criar versus mentir retoma a ideia já expressa na crônica "Uma porta abstrata". G.H. diz que vai "criar a verdade", tentar "mais uma reprodução do que uma expressão", ao invés de mentir, expressar-se - e, à frente, ela mesma fala: "manifestar o inexpressivo é criar. (...) quando a arte é boa é porque tocou no inexpressivo, a pior arte é a expressiva, aquela que transgride o pedaço de ferro e o pedaço de vidro, e o sorriso, e o grito"; "Quero o inexpressivo"216. A protagonista deseja realmente trazer a realidade para a obra; realidade, essa, que a personagem experimentou ao tocar o neutro do inseto. O que se chama de reprodução seria uma forma mais fiel de transpor sua vivência ao leitor ${ }^{217}$; todavia, relembrando as reflexões de Alfredo Bosi $^{218}$ : sabe-se que toda a reprodução é ficção, já que o artista elabora formalmente o mundo, sua visão da realidade. Não há mimese absoluta, cópia integral da realidade. $\mathrm{O}$ artista sempre elabora formalmente seu ponto de vista, seja na reprodução/criação ou na expressão/mentira. $\mathrm{O}$ anseio de se reproduzir, aqui, o episódio de

\footnotetext{
215 É interessante comparar, aqui, a intenção de G.H. em transmitir a verdade com sua arte - a escultura -, uma vez que um dos atributos da escultura apontadas por alguns estudiosos é justamente seu caráter mais "real" do que algumas outras artes visuais, como a pintura, uma vez que a escultura é tridimensional e, assim, ocupa um espaço mais efetivo no mundo concreto:
}

La escultura es una forma artística que utiliza directamente el espacio real, a diferencia de la pintura, que crea un espacio ficticio sobre un simple plano. La escultura, al ser tridimensional, tiene que ocupar un espacio efectivo, estar en interacción con el mismo o englobarlo. Una forma puede ser compacta o sólida, o estar provista de resaltes que se introducen en el medio que la rodea. Puede ser hueca, lineal o agujereada, dando acceso a su propio espacio interno. Puesto que la escultura tiene que tener una existencia real, aunque sólo sea temporal, en un mundo complejo y confuso, el escultor debe ser capaz de emparejar la percepción y la imaginación con conocimientos prácticos y técnicos. (MIDGLEY, Barry (org.). Guia completa de escultura, modelado y ceramica: tecnicas y materiales. Madrid: Hermann Blume Ediciones, 1981, p. 8)

216 Respectivamente: PSGH, p. 142-143; PSGH, p. 158.

${ }^{217}$ Retoma-se aqui a afirmação de Yudith Rosenbaum sobre a pintura de Janair: as pinturas rupestres, das quais o mural de Janair se assemelha, pode ter como função "acenar para um mundo onde coisa e imagem sejam indissolúveis" (ROSENBAUM, 2006, p. 170). Ou seja, as fronteiras entre arte e realidade se dissolvem, e parece ser isso o que deseja G.H. - talvez muito mais do que uma representação, uma apresentação efetiva, sem intermédios, de sua experiência. No entanto, isso seria impossível para a narradora, a não ser que ela própria também fizesse, como Janair, uma arte esteticamente paleolítica, em que há uma espécie de "magia" na qual o desenho constituiria, ao mesmo tempo, a representação e a coisa representada (Ibidem, p. 159). Para isso, então, G.H. não deveria ter se manifestado na arte da escrita propriamente dita, mas na do desenho.

218 In: Reflexões sobre a arte. 
G.H. é justamente o de "ir à coisa", através, agora, da literatura. Quimérico, portanto, já que, como discutido, em termos artísticos, é impossível de se chegar a ela ${ }^{219}$ : ao tentar tocar o it através da escrita, toca-se o reflexo dele, sua imagem, e não o it em si - no caso, o que se tocará é a imagem da memória de G.H., já que o relato é feito após a experiência ocorrida. Como já comentado, tocar a coisa por meio da expressão artística é sempre impossível.

Contudo, no início da narrativa, G.H. ainda demonstra seu difícil desejo de realizar essa impossibilidade pela arte. Por isso ela afirma tentar "mais uma reprodução do que uma expressão". Novamente a contraposição entre as duas formas de arte - que, aqui, se mostra interessante também para pensar como essa preferência pode estar em concordância com o processo de despersonalização de G.H.. Retoma-se a oposição expressão versus representação - que, como já visto, é repensada por G.H., a partir da transfiguração dos conceitos proposta por Clarice: a representação, para ela, seria a arte que de fato atinge a coisa, o inexpressivo, chegando ao âmago do mundo; enquanto a expressão seria, em resumo, a arte mais convencional, feita com certa influência da sensibilidade humana para (re)criar o mundo (a "expressão dada ao corpo" da Vênus, e não a expressão própria, inerente a ela, como se afirma em "Uma porta abstrata"). A expressão, de fato, parece ser uma escolha estranha para uma experiência de desmontagem do humano. Se não há mais humano, não haveria, em consequência, expressão. Se G.H. passa pelo esfacelamento de sua humanidade, como retratar essa experiência de forma sensível, expressiva, se não há mais o indivíduo para unir sua força como sujeito no mundo, transformando-a em forma artística? Talvez isso justifique, também, a predileção pela representação, a qual, em tese, para G.H., não só retrataria mais fidedignamente a realidade, sua vivência e sua despersonalização, mas a permitiria "tocar na coisa" também pela arte - que, como já visto, é impraticável. Se G.H. se despersonaliza chegando ao neutro, ao inexpressivo, é quimérico pensar que sua arte conseguirá traduzir verdadeiramente essa experiência indescritível, não apenas reproduzindo-a mimeticamente, mas alcançando novamente o $i$, agora pelo fazer artístico.

Ao introduzir essa dicotomia entre representação e expressão para tentar caracterizar seu relato, G.H. afirma que sua narrativa se construirá como um grafismo mais que como uma escrita propriamente dita. O grafismo, ou seja, uma forma de desenho, aproxima-se do esculpir, isto é, constitui uma arte propriamente visual, teoricamente (para a narradora) reproduzindo mais do que exprimindo. Novamente, o elemento das artes plásticas surge na

${ }^{219}$ E G.H. se deu conta disso ao final de sua jornada: "a coisa nunca pode ser realmente tocada. (...) A coisa para mim terá que se reduzir a ser apenas aquilo que rodeia o intocável da coisa? (...) ele, o homem, cuida do que lhe deste e envolve-se num invólucro feito especialmente para eu tocar e ver." (PSGH, p. 138) 
escrita e na discussão de G.H. sobre sua própria arte. Suas raízes como escultora não serão negadas durante o relato, e o elemento visual - tal qual visto, até agora, com a imagem da mão decepada do leitor e das bolinhas de pão - permanecerá na sua identidade como artista mesmo quando a protagonista escultora for relatar sua experiência. Ademais, o desenho é também a expressão de Janair: mais especificamente, os desenhos pré-históricos, que tendem à representação no sentido estrito (mimese). Como será discutido mais à frente, é interessante perceber como o desejo artístico de G.H. parece apresentar-se nesse outro das classes menos favorecidas, invisível a ela até então.

Ao desejar saber "o que mais, ao perder, eu ganhei" , é possível perceber que a incessante procura por dar forma à sua experiência - recorrendo, assim, à escrita, esse infortúnio e necessário modo de mediação - contribuirá sempre para a contínua perda de G.H., que a acomete desde seu instante vertiginoso no quarto da empregada, fato que a remove de sua vida organizada, desestruturando-a, fazendo-a sempre se deparar com o ocorrido, permanecendo, assim, entre a espiral dos doze travessões que contam sua história:

Na condição humana e na condição de escritor, ela [G.H.] vive a tentação de saber, de designar a coisa. Simbolizando-a ou indiciando-a de fora, porém, ela a perde. (...)

Escrever é por isso a grande proibição. (...)

A palavra é proibida porque sempre se vai além da coisa. Porém, jamais se poderá atingir a coisa se não se passar pela proibição da palavra - esta a incubência do escritor.

Missão paradoxal, porque não tem porta de saída. ${ }^{220}$

Em A paixão segundo G.H. a narração caminha, por assim dizer, à contracorrente da experiência narrada. É o paradoxo egológico desse romance: a narração que acompanha o processo de desapossamento do eu, e que tende a anular-se juntamente com este, constitui o ato desse mesmo eu, que somente pela narração consegue reconquistar-se. Por isso mesmo, extrema-se aqui o drama da linguagem: a narrativa é o espaço agônico do sujeito e do sentido - espaço onde ele erra, isto é, onde ele se busca -, o deserto em que se perde e se reencontra para de novo perder-se, juntamente com o sentido daquilo que narra, num processo em círculo, que termina para recomeçar, e cujo início não pode ser mais que um retorno. ${ }^{221}$

Nota-se que o perder-se constitui um fator essencial para a protagonista de $A$ paixão segundo G.H.. É na desorganização, perdendo sua "terceira perna", que ela poderá reorganizar-se; é no erro e na experiência com o imundo, a barata, que G.H. conseguirá conhecer a verdade acerca do mundo e de si mesma. E é no drama da linguagem, usando os termos de Benedito Nunes - ou, talvez, no drama da representação visual a partir da busca pela comunicação da experiência além da palavra, no caso de G.H. -, ou seja, é na palavra

220 SÁ, 2004, p. 147-148, grifos meus.

221 NUNES, 1995, p, 76, grifos meus. 
como um erro que G.H. consegue relatar os fatos vividos. O movimento espiralado novamente aparece na passagem de Nunes: perder-se faz parte do processo de (auto)conhecimento, de reconquista de si e do mundo após a visão do que ela chama de "verdade". E é esse perder-se que poderá fazer de G.H. uma nova pessoa. A figura circular, "que termina para recomeçar", também simboliza esse cansativo processo do aprendizado que, na verdade, nunca se finda: assim como a narrativa parece ser fechada em si mesma, dando a sensação de continuidade introvertida, assim também o é a aprendizagem do sujeito no mundo. Como tal processo é individual e, sobretudo, solitário, a necessidade de comunicação cresce em G.H. de forma que ela se vê impossibilitada de guardar apenas para si o conhecimento adquirido. Por isso, a imagem escultórica da mão do leitor se faz necessária: a carência de G.H. por uma companhia que lhe dê a mão se mostra como indispensável para que ela possa reconstituir a experiência vivida através da arte - seja ela da palavra ou da escultura, ou até uma espécie de mistura das duas, que é o que se quer defender aqui.

Enfim, após o adiamento de G.H. ${ }^{222}$, no início da obra, em narrar o ocorrido, descrevendo-se a si mesma e seus objetivos com a narrativa, ela começa a contar o que se sucedera depois da demissão da empregada e de sua decisão por limpar e organizar a casa sozinha, começando pelo antigo quarto de Janair. G.H., apesar de ter descrito como ela já estaria, de alguma forma, preparada para sua experiência (já que a escultura lhe servira de pré-clímax), parece ao mesmo tempo não ter tido nenhum tipo de antecedente que a levaria a suportar sozinha esse tipo de vivência. E é graças a essa ausência que tal narrativa tão singular e intrigante se constrói.

\subsection{Entre o eu e o outro, a arte: o desenho de Janair}

Finalmente, depois de se apresentar, de decidir pela narrativa e de inventar seu leitor, G.H. começa a contar o que lhe acometeu ao entrar no quarto da empregada, com o primeiro intuito de limpá-lo e organizá-lo.

Entretanto, G.H. se depara com "um quarto inteiramente limpo. (...) um quarto que tinha uma ordem calma e vazia" ${ }^{223}$. Após a surpresa por seu plano ter sido interrompido, a protagonista nota uma pintura na parede, deixada por Janair:

\footnotetext{
222 "Estou adiando. Sei que tudo o que estou falando é só para adiar - adiar o momento em que terei que começar a dizer, sabendo que nada mais me resta a dizer.". PSGH, p. 20.

223 PSGH, p. 36-37.
} 
Na parede caiada, contígua à porta - e por isso eu ainda não tinha o visto - estava quase em tamanho natural o contorno do carvão de um homem nu, de uma mulher nua, e de um cão que era mais nu do que um cão. (...) eram os contornos de uma nudez vazia. O traço era grosso, feito com ponta quebrada de carvão. Em alguns trechos o risco se tornava duplo como se um traço fosse o tremor do outro. Um tremor seco de carvão seco.

A rigidez das linhas incrustava as figuras agigantadas e atoleimadas na parede, como de três autômatos. Mesmo o cachorro tinha a loucura mansa daquilo que não é movido por força própria, $\mathrm{O}$ malfeito do traço excessivamente firme tornava o cachorro uma coisa dura e petrificada, mais engastada em si mesmo do que na parede.

Passada a primeira surpresa de descobrir em minha própria casa o mural oculto, examinei melhor, dessa vez com surpresa divertida, as figuras soltas na parede. Os pés simplificados não chegavam a tocar na linha do chão, as cabeças pequenas não tocavam a linha do teto - e isso, aliado à rigidez estupidificada das linhas, deixava as três figuras soltas como três aparições de múmias. À medida que mais e mais me incomodava a dura imobilidade das figuras, mais forte se fazia em mim a idéia de múmias. Elas emergiam como se tivessem sido um porejamento gradual do interior da parede, vindas lentamente do fundo até terem sudorado a superfície da cal áspera.

Nenhuma figura tinha ligação com a outra, e as três não formavam um grupo: cada figura olhava para a frente, como se nunca tivesse olhado para o lado, como se nunca tivesse visto a outra e não soubesse que ao lado existia alguém.

(...) cada figura se achava ali na parede exatamente como eu mesma havia permanecido rígida de pé à porta do quarto. $\mathrm{O}$ desenho não era um ornamento: era uma escrita. $(\ldots)^{224}$

Essa segunda surpresa da protagonista apresenta alguns pontos interessantes no que se refere ao estudo das artes visuais. Primeiramente, nessa passagem, nota-se como a descrição viva do grafismo faz com que o leitor consiga praticamente ver a pintura, a qual, inclusive, como já notou a crítica da autora, parece apresentar traços da pintura rupestre - "O traço era grosso, feito com ponta quebrada de carvão"; "A rigidez das linhas incrustava as figuras agigantadas e atoleimadas na parede"; "O malfeito do traço excessivamente firme" , além de ser, também, um "desenho hierático". Ainda nessa linha, citando o estudo de Solange Ribeiro de Oliveira, a pintura também demonstra traços de uma espécie de "história da arte ocidental, em alguns de seus momentos culminantes"225. Nas palavras de Oliveira:

Enquanto se busca no mural, a artista sente-se regredir no tempo. Das "camadas e camadas arqueológicas humanas". Assim reveladas, emergem resquícios dos períodos artísticos que marcam a passagem do homem pela terra. A arte rupestre, de Altamira e Lascaux, comparece quando G.H. imagina o "mural" como uma representação pré-histórica dela mesma: "há muito fui desenhada (...) numa caverna" (p. 110). Inúmeras alusões à arte egípcia contribuem para sugerir a beleza que, aos poucos, G.H. passa a atribuir a Janair, fazendo da "negra africana" uma espécie de rainha egípcia (p. 110). As figuras esboçadas na parede pela doméstica são "desenhos hieráticos" (p. 37), homem, mulher e cachorro

\footnotetext{
224 PSGH, p. 38-39.

225 OLIVEIRA, Solange Ribeiro de. Literatura e artes plásticas: O künstlerroman na ficção contemporânea. Ouro Preto: UFOP, 1993, p. 85.
} 
transformam-se em "três figuras angulares de zumbis" (p. 37), "figuras de mão espalmada (...), sucessivos vigias à entrada do sarcófago (p. 45). Como se velassem o túmulo de uma soberana, colocam-se a um passo da "descoberta de um império" (p. 19). Também se mencionam "reis, esfinges e minaretes" (p. 34). A arte grega pode ser vislumbrada nas semelhanças imaginadas entre o Rio de Janeiro e a "cidade grande e límpida, Atenas no seu apogeu" (p. 104), a bizantina, na evocação de Constantinopla (p. 104). A Renascença desponta na alusão à Mona Lisa, imagem do mistério humano: "todos os retratos das pessoas são um retrato de Mona Lisa" (p. 23). G.H. não esquece o barroco, sugerido pelos efeitos de claro-escuro, o contraste obsessivamente lembrado, entre a claridade ofuscante que G.H. enxerga no quarto de Janair, "claridade natural do que existe" (p. 14) e "as misturas de sombras que prenunciavam o living" de sua casa (p. 26). Finalmente, surgem as alusões ao cubismo, "estilo moderno arquetípico". São inspirados no cubismo os efeitos obtidos pela visão multidimensional que G.H. tenta dar de si mesma. Apresenta-se como "mulher de generosidade e graça, que não dá trabalho a um homem (...) mulher que ri e sorri (p. 7). Mas enxerga-se também na "mulherona nua" desenhada por Janair, e na "realidade incompreensível" de suas fotografias (p. 17). Tentando transmitir não só a auto-imagem, mas aquela que lhe chega, em ricochete, do seu reflexo nos olhos do Outro, G.H. menciona a pintura cubista, esforço de representar, sem perspectiva, as três dimensões na superfície da tela plana: "Eu era aquela a quem o quarto chamava de 'ela', ali entrara um eu a que o quarto dera uma dimensão de ela. Como se eu fosse também o outro lado do cubo, o lado que não se vê porque se está vendo de frente" (p. 56). Essa visão, que lhe é devolvida pelo espelho do olhar alheio - o olhar que ela atribui a Janair, alguém de outra classe social, de outro mundo cultural - chega a G.H. primeiro pelo desenho feito pela empregada na parede. ${ }^{226}$

A história da artista G.H. e a história da arte ocidental parecem, então, se confundir nesses momentos - o que dá sentido, de certa forma, a toda a questão da ancestralidade prenunciada pela narradora desde o início da obra, e que irá se aprofundar com a visão da barata, inseto milenar. $\mathrm{O}$ sujeito artista parece ser mostrado, aqui, também como um ser antigo, que habita o mundo desde que o homem pré-histórico desenhou, pela primeira vez, seu universo em uma pedra.

Além disso, voltando ao trecho da narrativa clariceana, vê-se, no final da passagem, como G.H. atribui significado ao desenho, dizendo que ele "não era um ornamento: era uma escrita". Essa reflexão, de certa forma, concorda com o que a própria Clarice escreveu sobre a pintura, em um texto já mencionado: "Se eu pudesse escrever por intermédio de desenhar na madeira (...) jamais teria entrado pelo caminho da palavra"227. Ou seja: o desenho, a arte visual, também pode ser uma escrita, uma forma com tanto significado tal qual a arte literária - conforme pensado por Horácio: ut pictura poesis, como a pintura é a poesia ${ }^{228}$. Da mesma maneira reflete Mário de Andrade sobre essa arte: "O que me agrada principalmente na tão complexa natureza do desenho, é o seu caráter infinitamente subtil, de ser ao mesmo tempo

\footnotetext{
226 Ibidem, p. 85-86.

227 LISPECTOR, 1999, p. 285.

228 HORÁCIO. Arte poética. Lisboa: Editorial Inquérito Lisboa, p. 109.
} 
uma transitoriedade e uma sabedoria. O desenho fala, chega mesmo a ser muito mais um espécie de escritura, uma caligrafia, que uma arte plástica"229.

Logo após o primeiro impacto ao ver o desenho, G.H. parece interpretá-lo, reconhecendo, nas figuras da parede, uma crítica da empregada a seu próprio modo de vida, ao passo que ela se identifica com a representação gráfica:

Eu olhava as figuras de homem e mulher que mantinham expostas e abertas as palmas das mãos vigorosas, e que ali pareciam ter sido deixadas por Janair como mensagem bruta para quando eu abrisse a porta.

Meu mal-estar era de algum modo divertido: é que nunca antes me ocorrera que, na mudez de Janair, pudesse ter havido uma censura à minha vida, que devia ter sido chamada pelo seu silêncio de "uma vida de homens"? como me julgara ela?

Olhei o mural onde eu devia estar sendo retratada... Eu, o Homem. E quanto ao cachorro - seria este o epíteto que ela me dava? Havia anos que eu só tinha sido julgada pelos meus pares e pelo meu próprio ambiente que eram, em suma, feitos de mim mesma e para mim mesma. Janair era a primeira pessoa realmente exterior de cujo olhar eu tomava consciência. (...)

E fatalmente, assim como ela era, assim deveria ter me visto? abstraindo daquele meu corpo desenhado na parede tudo o que não era essencial, e também de mim só vendo o contorno. No entanto, curiosamente, a figura na parede lembrava-me alguém, que era eu mesma. $^{230}$

Nota-se como G.H. parece perceber, então, o ponto de vista de um outro, de classe social mais baixa, sobre sua vida essencialmente burguesa, compondo, assim, a relação de "identidade/alteridade social" que Daniela Kahn categorizou a respeito de algumas obras clariceanas $^{231}$ : a partir da visão do outro, tem-se a visão de si mesma - Solange Ribeiro de Oliveira, no trecho inserido anteriormente, reflete da mesma forma, ao mencionar a pintura cubista em G.H. (o desenho de Janair, visto assim pela protagonista) e como ela seria um "espelho do olhar alheio", contribuindo para "refletir nos olhos do Outro" a visão da exempregada, "alguém de outra classe social, de outro mundo cultural" ${ }^{232}$, sobre o modo de vida diferente da ex-patroa.

Ao mesmo tempo que percebe o ponto de vista desse outro, a perspectiva sobre seu próprio modo de vida começa a ficar abalada - e, posteriormente, é rompida de vez com a visão da barata e a reflexão que se sucede. G.H. reconhece a si mesma na figura do homem desenhado, e interpreta o cachorro do mural como sendo seu epíteto - talvez um modo de

\footnotetext{
229 ANDRADE, Mário de. "Do desenho". In: Aspectos das artes plásticas no Brasil. São Paulo: Livraria Martins Editora, 1965, p. 71, grifos meus.

${ }^{230}$ PSGH, p. 39-40, grifos meus.

${ }^{231}$ KAHN, Daniela. A via crucis do outro: identidade e alteridade em Clarice Lispector. São Paulo: Associação Editorial Humanitas: FAPESP, 2005.

232 OLIVEIRA, 1993, p. 86.
} 
Janair mostrar à mulher como ela segue lealmente, como o cão, o que lhe é imposto: no caso de G.H., a vida luxuosa da alta burguesia, em seu ostensivo apartamento, não refletindo sobre isso, mas apenas vivendo de acordo com o que lhe é demandado ou esperado; como um animal domesticado que, ao invés de seguir seus instintos e sua independência, contenta-se com a vida que lhe é ensinada a viver ${ }^{233}$. Assim, G.H. parece abstrair, da parede desenhada, uma espécie de início de transgressão e de sua consequente emancipação. Tal qual a narradora de outro texto clariceano - crônica que segue na íntegra:

\section{Medo da libertação}

Se eu me demorar demais olhando Paysage aux Oiseaux Jaunes (Paisagem com Pássaros Amarelos, de Klee), nunca mais poderei voltar atrás. Coragem e covardia são um jogo que se joga a cada instante. Assusta a visão talvez irremediável e que talvez seja a da liberdade. O hábito que temos de olhar através das grades da prisão, o conforto que traz segurar com as duas mãos as barras frias de ferro. A covardia nos mata. Pois há aqueles para os quais a prisão é a segurança, as barras um apoio para as mãos. Então reconheço que conheço poucos homens livres. Olho de novo a paisagem e de novo reconheço que covardia e liberdade estiveram em jogo. A burguesia total cai ao se olhar Paysage aux Oiseaux Jaunes. Minha coragem, inteiramente possível, me amedronta. Começo até a pensar que entre os loucos há os que não são loucos. E que a possibilidade, a que é verdadeiramente, não é para ser explicada a um burguês quadrado. E à medida que a pessoa quiser explicar se enreda em palavras, poderá perder a coragem, estará perdendo a liberdade. Les Oiseaux Jaunes não pede sequer que se o entenda: esse grau é ainda mais liberdade: não ter medo de não ser compreendido. Olhando a extrema beleza dos pássaros amarelos calculo o que seria se eu perdesse totalmente o medo. O conforto da prisão burguesa tantas vezes me bate no rosto. E, antes de aprender a ser livre, tudo eu aguentava - só para não ser livre. ${ }^{234}$

A pintura (do outro) como libertação: parece ser isso que o desenho de Janair e Paysage aux Oiseaux Jaunes proporcionam às suas respectivas observadoras. Parece, inclusive, que G.H. e a narradora da crônica poderiam ser até a mesma pessoa: assustadas com a visão da liberdade; aceitando o conforto reconhecido na prisão social; reconhecendo, com as pinturas, a burguesia em jogo; descobrindo em si uma coragem anteriormente encoberta e domada. E mais ainda: a aceitação (mesmo inconsciente) de se viver atrás das grades, aguentando todas as demandas sociais "só para não ser livre", para não passar pela dor da travessia de purificação e de independência que ambas as narradoras pareceram atravessar justamente através da arte - arte essa, diga-se de passagem, feita por um outro alguém, ora conhecido e inserido como um outro oposto de si, como Janair; ora um pintor de fato renomado, como Klee.

\footnotetext{
233 "Essa coisa sobrenatural que é viver. O viver que eu havia domesticado para torná-lo familiar". PSGH, p. 16.

${ }^{234}$ LISPECTOR, 1999, p. 198.
} 
O que seria se G.H. perdesse totalmente o medo? - como reflete a narradora da crônica. O que seria dela se decidisse não mais aceitar o conforto da prisão burguesa e tantas outras circunstâncias que a impediam de ser livre? Ao olhar a pintura estilisticamente arcaica da antiga empregada, cuja simplicidade não deixa também de remeter a algo da arte de vanguarda, G.H. inicia um caminho desértico que pode responder, justamente, a essas perguntas feitas na crônica. Todas essas questões são enfrentadas, a sua maneira, por essa personagem, não só a partir da pintura de Janair (que pode servir, ainda, como um prenúncio de uma outra visão posterior e mais surpreendente), mas principalmente a partir do elemento que a protagonista nota após o desenho na parede: a barata.

\subsection{A barata: uma escultura na escrita}

Com o desenho de Janair, G.H. se deparou com a visão artística de um outro sobre si mesma, deixada propositalmente pela antiga empregada. Reconhecendo-se nele, G.H. nota como o outro, de outra classe social, a enxergava. No entanto, parece haver uma mudança de perspectiva a partir de um novo elemento que aparece na narrativa: a barata. Aqui, parece haver, diferentemente do mostrado com o desenho na parede, um outro (também estranho e diferente dela) que a faz buscar em si mesma uma imagem mais genuína do eu, percebendo todos os cárceres que a mantiveram naquela vida pré-experiência. Assim, os papéis de Janair e da barata parecem se complementar a fim de mostrar a G.H. quem era o outro ainda invisível a ela, além de promoverem uma jornada de autoconhecimento a partir, justamente, da visão desse outro - tanto dele sobre G.H., no caso do desenho de Janair; quanto de G.H. sobre ele, no caso da barata.

Na sequência de se deparar com o desenho de Janair, G.H. vê, então, esse inseto. Após o choque inicial, devido principalmente ao asco, a narradora começa a perceber as características físicas da barata, descrevendo-a a seu leitor:

Era uma cara sem contorno. As antenas saíam em bigodes dos lados da boca. A boca marrom era bem delineada. Os finos e longos bigodes mexiam-se lentos e secos. Seus olhos pretos facetados olhavam. Era uma barata tão velha como um peixe fossilizado. Era uma barata tão velha como salamandras e quimeras e grifos e leviatãs. Ela era antiga como uma lenda. Olhei a boca: lá estava a boca real. (...)

E eis que eu descobrira que, apesar de compacta, ela é formada de cascas e cascas pardas, finas como as de uma cebola, como se cada uma pudesse ser levantada pela unha e no entanto sempre aparecer mais uma casca, e mais uma. Talvez as cascas fossem as asas, mas então ela devia ser feita de camadas e camadas finas de asas comprimidas até formar aquele corpo compacto.

Ela era arruivada. E toda cheia de cílios. Os cílios seriam talvez as múltiplas pernas. 
Os fios de antena estavam agora quietos, fiapos secos e empoeirados. A barata não tem nariz. Olhei-a, com aquela sua boca e seus olhos: parecia uma mulata à morte. Mas os olhos eram radiosos e negros. Olhos de noiva. Cada olho em si mesmo parecia uma barata. O olho franjado, escuro, vivo e desempoeirado. E o outro olho igual. Duas baratas incrustadas na barata, e cada olho reproduzia a barata inteira. ${ }^{235}$

Ainda, após o golpe com a porta, rompendo o corpo da barata, G.H. nota sua massa branca saindo de seu corpo:

A matéria da barata, que era o seu de dentro, a matéria grossa, esbranquiçada, lenta, crescia para fora como de uma bisnaga de pasta de dentes.

Diante de meus olhos enojados e seduzidos, lentamente a forma da barata ia se modificando à medida que ela engrossava para fora. A matéria branca brotava lenta para cima de suas costas como uma carga. Imobilizada, ela sustentava por cima do flanco empoeirado a carga do próprio corpo. (...)

A grossura branca imobilizara-se agora por cima das cascas. Olhei para o teto, descansando um pouco os olhos que eu sentia terem se tornado fundos e grandes. ${ }^{236}$

A partir dessas descrições feitas por G.H. ao leitor, vê-se como o corpo da barata e o seu de dentro parecem ser, diferentemente do desenho de Janair (em que as figuras pintadas são planas, sem relevo, como é a arte da pintura e do desenho), de fato vivos, germinantes, ovulantes, semelhantemente às esculturas de Mário Cravo que Clarice descreveu - ainda, nota G.H. mais à frente: "Os dois olhos eram vivos como dois ovários. Ela me olhava com a fertilidade cega de seu olhar"; "Seus olhos continuavam monotonamente a me olhar, os dois ovários neutros e férteis". ${ }^{237}$ Ademais, por conta também dessa vitalidade do animal, o mesmo corpo parece estar mais próximo da tridimensionalidade do que da bidimensionalidade - estando, portanto, mais próximo de uma arte da primeira categoria (a escultura) do que da segunda (a pintura e o desenho) -: há os movimentos da barata, como os "bigodes mexendo"; a ideia de seu corpo compacto e formado de cascas (essas, inclusive, podendo ser facilmente tocadas e levantadas pela mulher); a "matéria grossa, esbranquiçada" crescendo lentamente para fora do condensado corpo, que também é caracterizado como

\footnotetext{
${ }^{235}$ PSGH, p. 54-55. Destaca-se, aqui, o espelhamento da barata em si mesma, criando uma espécie de impressão de infinitude do inseto: cada olho a reproduzia, o que pode remeter à técnica chamada mise en abyme. Nota-se esse termo sendo utilizado tanto para pintura quanto para narrativa. Expressado pela primeira vez pelo escritor André Gide, o termo se refere, na pintura, quando tem-se um quadro que, dentro de si, há ele próprio em uma cópia menor, causando um efeito especular, na qual nossa visão é colocada, então, em abismo (ver a referência: https://quadrosdecorativos.net/mise-en-abyme-na-pintura/). Nas narrativas, esse efeito foi denominado de forma diferente por Todorov em As estruturas narrativas como "encaixe", para designar as narrativas que aparecem dentro de outras, como o caso de As mil e uma noites. Esse aspecto será retomado mais à frente, na análise formal do relato de G.H. e de sua relação com a escultura.

${ }^{236}$ PSGH, p. 61.

${ }^{237}$ Respectivamente: PSGH, p. 76; PSGH, p. 90.
} 
"grosso". Portanto, graças à visão total que G.H. e o leitor têm do inseto, notam-se, na descrição, a robustez de sua constituição física, as cascas que se podem pegar com as unhas e levantá-las, a vida e o movimento que é visto no animal, em seu interior e exterior. Assim, por poder de fato tocar na barata, notando suas camadas, e por poder vê-la em todos os seu ângulos, além de poder notar, também, a vida que emanava dela e, por fim, por ela estar situada com um espaço efetivamente físico naquela realidade (o quarto da empregada, estando no guarda-roupa dela), sua descrição parece se adequar na narrativa muito mais ao que seria uma arte tridimensional, a escultura, a qual de fato ocupa um espaço na realidade e é vista pelo observador de forma mais completa, do que à arte que, em um plano achatado, pinta e desenha imagens sem corpulência e relevo, em uma tela ou papel. Assim parece ser o modo com que G.H. pode unir as duas artes que comparecem na obra: a escultura e a narrativa literária.

"Fazer com as mãos aquilo que se vê"238. eis o segredo desvendado por Rodin para construir suas obras de arte escultóricas. G.H., ao passar da arte visual para a verbal, parece remontar essa máxima: "(d)escrever com as palavras aquilo que se vê". Princípio aparentemente singelo, porém poderoso: é a palavra que esculpe. Com isso, a descrição do inseto asqueroso ganha tanta força que parece, de fato, estar a barata viva, agonizante, na frente do seu leitor. A tridimensionalidade - um dos aspectos principais da escultura, que "utiliza diretamente o espaço real, diferenciando-se da pintura, que cria um espaço fictício sobre um plano simples. A escultura, ao ser tridimensional, tem que ocupar um espaço efetivo, estar em interação com o mesmo e englobá-lo"239; ou, como para Lessing: a escultura seria a arte preocupada com o desdobramento de corpos no espaço, sendo diferente das artes (principalmente verbais) cujo meio é o tempo ${ }^{240}$ - parece estar inserida, assim, na escrita da escultora, a partir da corpulência tridimensional do inseto e do seu de dentro. Logo, a barata na narrativa aparenta ganhar um status de uma espécie de escultura verbal: mais do que simplesmente descrever o asqueroso animal, G.H. parece utilizar sua arte original para colocá-lo, como a uma escultura em um espaço efetivamente real, aos olhos do seu leitor, formando e organizando as partes de seu corpo - desde a "cara sem contorno", com seus

\footnotetext{
238 "Faire avec ses mains ce que l'on voit, voilà la loi souveraine...". In: RODIN, Auguste. Faire avec ses mains ce que l'on voit. Paris: Mille et une nuits, département de la Librairie Arthème Fayard, 2011, p. 23. Tradução livre.

239 "utiliza directamente el espacio real, a diferencia de la pintura, que crea un espacio ficticio sobre un simple plano. La escultura, al ser tridimensional, tiene que ocupar un espacio efectivo, estar en interacción con el mismo o englobarlo". In: MIDGLEY, Barry. Op. cit..

240 Apud KRAUSS, Rosalind. Passages in Modern Sculpture. Nova Iorque: The Viking Press, 1977, p. 3.
} 
cílios e olhos, passando pelo corpo com as grossas cascas e sua solidez, até a massa branca que sai do inseto -, posicionando-o de fato em um espaço (o quarto, ambiente principal da trama), demonstrando sua organicidade e parecendo retratar, assim, uma estátua do que vira. No entanto, quando se passa da arte visual para a escrita, ao invés dessa escultura verbal estar em um espaço real, ela estaria inserida, justamente, no campo enunciativo, apenas no espaço da palavra - para inserir o leitor na vivência da personagem com a barata.

Além disso, logo que a golpeia com a porta do guarda-roupa, G.H. compara a barata com uma obra artística: "E vi a metade do corpo da barata para fora da porta. Projetada para a frente, erecta no ar, uma cariátide. Mas uma cariátide viva" ${ }^{241}$. Parece que a narradora, assim, pretende de fato passar a imagem do inserto para a narrativa de forma a se aproximar mais com sua visão, a qual, por sua vez, remete-a à a arte espacial: as estátuas gregas de mulheres que serviam de pilastras na entrada de edifícios. Contudo, a cariátide-barata era viva, e não uma obra de arte em si; justamente, a barata se transforma em escultura enquanto o relato se transforma em literatura. ${ }^{242}$ Ainda, tal qual as cariátides gregas serviam para sustentar a parte superior das construções arquitetônicas, a cariátide do inseto também poderia estar sustentando algo: talvez o antigo mundo de G.H., que desmorona justamente quando essa cariátide-barata se quebra ao meio, permitindo-a provar o seu neutro de dentro.

Arte do tempo e arte do espaço parecem, assim, juntarem-se nesse momento de descrição da barata na narrativa. Conforme Lessing:

todos os corpos não existem apenas no espaço, mas também no tempo. Eles perduram e podem parecer diferentes e se encontrar numa outra relação em cada momento da sua duração. Cada uma dessas aparições momentâneas e relações é o efeito de uma anterior e pode ser a causa de uma sucessiva e, assim, como que o centro de uma ação. ${ }^{243}$

Apesar, então, de diferenciar arte do tempo e arte do espaço, de defender que a pintura não é como a poesia (que as artes visuais no geral não são como as verbais), restabelecendo as fronteiras entre essas artes, Lessing aponta o fato de que, como notou e argumentou Rosalind Krauss a respeito da escultura moderna, "mesmo na arte espacial, espaço e tempo

\footnotetext{
${ }^{241}$ PSGH, p. 53, grifos meus.

242 Ainda sobre isso, acrescenta-se: "Sabemos que as cariátides eram estátuas que serviam de coluna e guardavam a entrada das acrópoles. Ao aproximar a barata deste símbolo, percebemos que, para G.H., este inseto guarda também uma grande revelação. Desta forma, ao passar pela barata, G.H. deixa o mundo anterior para entrar em um mundo novo, ou seja, vive o conhecimento de si mesma através do outro (a barata)". In: ALONSO, Mariângela; LEITE, Guacira Marcondes Machado. "O substrato mítico em A paixão segundo G.H.". Revista de Letras, Universidade Federal do Ceará, v.1, n. 29, 2007, p. 15.

${ }^{243}$ LESSING, G. E. Laocoonte ou sobre as fronteiras da pintura e da poesia. São Paulo: Editora Iluminuras, 2011, p. 195.
} 
não podem ser separados para propósitos de análise. Em qualquer organização espacial haverá guardada uma declaração implícita sobre a natureza da experiência temporal" ${ }^{244}$. Isso pode, de alguma forma, servir de argumento também aqui: na junção das duas artes, ao decidir pela narrativa e não pela sua escultura para contar o ocorrido, o relato de G.H. acaba por não separar, portanto, espaço de tempo; a literatura, neste caso, encarrega-se de fazer o jogo de simultânea descrição e modelagem escultórica da imagem do inseto. A declaração implícita sobre a natureza da experiência temporal de G.H. ocorre, aqui, explicitamente; concomitantemente, a protagonista, narrando o que lhe acontecera, apresenta sua organização espacial da barata (figura que age como um centro da ação da narrativa), apesar desta ocorrer apenas no plano verbal, já que haveria um leitor que, não presente na cena, deveria ver, de alguma forma, o que G.H. viu. Por isso, a descrição do animal parece ser não apenas uma mera definição dele: por ter como objetivo demonstrar sua vivacidade ao leitor, por querer que ele veja o que ela vira, querendo dar a ele a sua exata experiência - "Perdoa eu te dar isto, mão que seguro, mas é que não quero isto para mim! toma essa barata, não quero o que vi." 245 - G.H. parece utilizar um recurso antigo da retórica grega: a écfrase, que será melhor trabalhada nas próximas seções deste texto.

\subsection{Um possível ready made}

Antes, ainda, de partir para a écfrase, um último ponto pode ser explicitado: é importante afirmar, apesar da aparente obviedade, que a barata não é uma escultura per se; pelo contrário, G.H. toma o inseto, já existente na natureza; e, ao deslocá-lo, faz dele um novo objeto. Esse modo artístico parece se assemelhar a uma forma de fazer escultura da modernidade: o ready made. ${ }^{246}$

Mais do que uma simples imitação do já existente, o ready made reposicionava objetos e outras peças, tirando-os de sua função primeva - como ilustra didaticamente a clássica Fonte de Duchamp. Segundo Rosalind Krauss, essa reposição de algo já pronto do mundo concreto para a arte faz com haja uma escultura caracterizada como "não mais um

\footnotetext{
${ }^{244}$ Tradução livre do trecho: "(...) even in a spatial art, space and time cannot be separated for purposes of analysis. Into any spatial organization there will be an implicit statement about the nature of temporal experience." KRAUSS, 1977, p. 4.

245 PSGH, p. 56.

246 Devo essa sugestão a Gilberto Figueiredo Martins, que, acompanhando minha qualificação desta dissertação, sugeriu-me a leitura de Rosalind Krauss e me indicou que, para ele, haveria certa semelhança, principalmente, entre a arte de Brancusi e a barata encontrada por G.H..
} 
objeto físico mas sim uma questão, e a produção dessa arte poderia, portanto, ser reconsiderada como assumindo uma forma perfeitamente legitimada no ato especulativo de colocar questões"247, as quais seriam "absolutamente estéticas, nas quais a obra em mãos se torna tanto uma afirmação geral quanto um exemplo específico" ${ }^{248}$. De forma semelhante reflete Peter Bürger, tendo como exemplo os ready mades de Duchamp:

Quando Duchamp, em 1913, assina produtos de série (urinol, garrafeira) e os envia às exposições, está negando a categoria de produção individual. A assinatura. que precisamente conserva a individualidade da obra, é o objeto do desprezo do artista, quando lança produtos anônimos, fabricados em série, contra toda a pretensão de criação individual. A provocação de Duchamp não só revela que o mercado da arte, ao atribuir mais valor a assinatura do que a obra, é uma instituição controversa, como ainda faz vacilar o próprio princípio da arte na sociedade burguesa, segundo o qual o indivíduo é o criador das obras de arte. Os ready mades de Duchamp não são obras de arte, mas manifestações. O sentido da sua provocação não reside na totalidade de forma e conteúdo dos objetos particulares que Duchamp assina, mas unicamente no contraste entre os objetos produzidos em série, por um lado, e a assinatura e as exposições de arte, pelo outro. É evidente que uma provocação assim não pode ser repetida em qualquer momento. A provocação depende da natureza do seu objetivo: neste caso da ideia de que a arte é criada por indivíduos. Porém, uma vez que o urinol assinado é aceito nos museus, a provocação deixa de ter sentido e transforma-se no seu contrário. Quando um artista dos dias de hoje assina e exibe uma chaminé de fogão, já não está a denunciar o mercado da arte: está a submeter-se a ele; não destrói, mas antes confirma, o conceito da criação individual. Haverá que procurar a razão disto no fracasso da intenção vanguardista de superar a arte. Quando o protesto da vanguarda histórica contra a instituição arte chega a considerar-se como arte, a atitude de protesto da neo-vanguarda tem que ser falsa. Daí a impressão de arte industrial que as obras neo-vanguardistas provocam com frequência. ${ }^{249}$

Assim, os ready mades seriam, usando os vocabulários próprios de Bürger, manifestações, provocações, denúncias - apesar de seu status contraditório, de questionar a arte tradicional e, no fim, submeter-se a ela, aceitando a categoria como produção individual ao invés de um objeto ironicamente reposicionado para desafiar os parâmetros artísticos -; analogamente ao que Krauss definiu: uma questão, não mais um objeto de arte; "parte de uma práxis vital emancipadora" 250 ao invés de produção artística.

No ready made, portanto, muitas vezes não é o objeto escultórico que está em foco, mas sim o significado por trás dessa produção: por que e para que essa reposição de algo não artístico para o campo artístico ocorreu? O mesmo pode-se questionar sobre a escultura

\footnotetext{
${ }^{247}$ Tradução livre de: "Clearly, one answer suggested by the readymades is that a work might not be a physical object but rather a question, and that the making of art might, therefore, be reconsidered as taking a perfectly legitimate form in the speculative act of posing questions." KRAUSS, 1977, p. 73.

248 Tradução livre de: "(..) absolute aesthetic questions for which the work at hand becomes both the general statement and the specific example". Ibidem, p. 76.

249 BÜRGER, Peter. Teoria da vanguarda. Lisboa: Vega, 1993, p. 93-95, grifos meus.

${ }^{250}$ Ibidem, p. 95.
} 
verbal da barata na obra clariceana: por que G.H. a descreve, transportando-a de forma tão real para a narrativa? Por que a partir dela se faz arte? - tanto a escultura quanto a própria obra literária. Como essa transposição da realidade de G.H. para a narrativa escultórica ocorre? A escultura descritiva da barata, mais do que feita para ser meramente contemplada, faz o leitor pensar a respeito da significância do inseto na experiência da protagonista. Do grotesco se faz arte para dar ao leitor a grotesca experiência vivida, organizando-a em uma forma - literária e descritiva-escultórica -; a partir de caracterizações aparentemente tridimensionais e animadas (como já explanado, a corpulência grossa do inseto e os movimentos, por exemplo, de seus cílios e de sua massa interior) e de elementos como a écfrase (que será abordado a seguir), em que a descrição não é o mero ato de expor as características de algo ou alguém, mas é uma ferramenta retórica importante para imitar e tornar vivo aos olhos do leitor/ouvinte o que se quer retratar, de modo que a barata se faz escultura verbal - uma espécie de ready made no enunciado, meio de emancipação da protagonista-artista e de sua prévia condição como obediente à sociedade. Aqui desponta um dos pontos centrais da análise: demonstrar como esse inusitado fazer escultórico, usando não os materiais táteis próprios da escultura, mas a palavra, pode ser um exemplo singular da obra clariceana em que uma artista escultora se faz presente por meio de uma espécie de escrita escultórica.

Um dos principais expoentes do readymade se faz interessante neste momento: Brancusi. Duas características de sua obra chamam a atenção, pensando, principalmente, na análise de Krauss sobre esse artista: a frequente representação de animais, além de humanos esculpidos ora de maneira extremamente simples - como "O beijo", em que há dois sujeitos aparentemente esculpidos no mesmo pedaço de gesso -, ora de maneira fragmentada - como exemplo, cito o mesmo que Krauss usou em seu livro: "O recém-nascido", em que há uma cabeça de um bebê isolada de seu corpo $^{251}$. As duas aparentes esculturas de G.H. - a mão decepada e a barata - podem ser inseridas nessas mesmas categorias: há o corpo fragmentado, a mão decepada do leitor, construída para que a narradora possa segurar e se apoiar enquanto narra o ocorrido ${ }^{252}$; e há a barata, animal asqueroso e milenar que aparece no guarda-roupa do quarto da empregada. Ainda sobre as peculiaridades de Brancusi, Krauss explicita que:

\footnotetext{
${ }^{251}$ Ver as imagens das esculturas citadas no anexo.

252 Segundo Krauss, essa fragmentação serve justamente para libertar o significado do gesto de seu sentido precondicionado pela estrutura subjacente: "the fragmentation of the body is one way of freeing the meaning of a particular gesture from a sense that it is preconditioned by the underlying structure of the body understood as a coherent whole.". KRAUSS, 1977, p. 279.
} 
a temporalidade da escultura de Brancusi é um produto da situação na qual o trabalho é colocado - as reflexões e contra reflexões que peculiarizam o objeto em seu lugar, fazendoo produto do espaço real que o observador encontra. Diferentemente do tempo analítico, em que o observador compreende a estrutura pressuposta do objeto, decifrando o relacionamento entre suas partes, e conectando tudo à lógica estrutural ou à primeira causa, a alternativa posicionada separadamente por Brancusi e Duchamp é a do tempo real, ou tempo experienciado. É o tempo vivido pelo qual alguém encontra o enigma, experienciando suas torções e seus desvios, sua resistência à ideia de "solução". Ou é a experiência da forma como é mostrada para ser aberta a mudanças através do tempo e do espaço - o contingenciamento da forma como uma função da experiência. ${ }^{253}$

A escultura do inseto na narrativa clariceana parece se fazer com a mesma temporalidade da obra de Brancusi: ela é "esculpida" no exato momento de relembrar a experiência para contá-la a um terceiro - momento esse que, por sua vez, parece não estar longe temporalmente do momento real que G.H. vivenciou. A barata é produto do espaço (e do tempo) real em que G.H. se encontra, sua escultura verbal sendo fruto necessário para expurgar de si as reflexões que a narradora teve a partir da visão desestruturante do animal no quarto da empregada.

\subsection{A poesia como a pintura, a escultura como a prosa}

Quem via tais figuras descobria que elas não haviam nascido de um mero capricho, nem de uma tentativa brincalhona de encontrar formas novas e inauditas. Foi a necessidade que as criou. A angústia provocada pelo julgamento invisível de uma forte crença, se refugiou nessa visibilidade; a incerteza buscou superar-se nessa realização. Tal realização, ainda a procuravam em Deus, mas não mais o inventando em imagens, ou tentando representá-lo no infinitamente longínquo: a devoção consistia em levar toda angústia e toda pobreza, todo medo e todos os gestos medíocres, para a casa de Deus, depositá-los em suas mãos e colocálos em seu coração. E isso era melhor do que pintar, pois a pintura era também uma ilusão, um hábil e belo engano, onde aspirava-se por realidade e simplicidade. Assim se engendravam as originais esculturas das Catedrais, essa cruzada de animais e de oprimidos. ${ }^{254}$

Tal descrição de Rilke sobre estátuas tipicamente encontradas em catedrais europeias - a maioria delas animais e santos -, as principais representações escultóricas que existiam,

\footnotetext{
253 "the temporality of Brancusi's sculpture is a product of the situation in which the work is placed- the reflections and counterreflections that tie the object to its place, making it the product of the real space in which the viewer encounters it. Unlike analytic time, in which the viewer grasps the a priori structure of the object, deciphering the relationship between its parts, and connecting everything to a structural logic or first cause, the alternative posited separately by Brancusi and Duchamp is that of real time, or experienced time. It is the lived time through which one encounters the riddle, experiencing its twists and deviations, its resistance to the very idea of "solution." Or it is the experience of form as it is shown to be open to change through time and place the contingency of shape as a function of experience." Ibidem, p. 106-108.

254 RILKE, Rainer Maria. Rodin. Rio de Janeiro: Relume-Dumará, 1995, p. 25-26.
} 
para o poeta, antes da arte de Rodin, pode ser usada, a sua maneira, para sintetizar a razão de G.H. em esculpir verbalmente sua barata: a necessidade da criação verbal e visual para o leitor, a fim de compartilhar sua experiência; a angústia dessa vivência, que deu origem à escultura verbal da barata (e da mão solitária). A experiência da paixão é vivida por G.H., que, pecando, provando do impuro da massa da barata, mata seu antigo eu, apoiado na terceira perna, identificado principalmente pela sua posição social dentro do apartamento luxuoso, a fim de viver, ela mesma, uma nova vida. Todo o medo e a mediocridade de sua vida antiga podem ser abandonados com essa experiência, que leva o nome de um episódio tradicionalmente cristão. Interessante que G.H. não opta pela arte mais desejada por Clarice Lispector, a pintura, e talvez aqui haja também uma resposta: a pintura ainda é uma arte da ilusão, enquanto a escultura, tendo um espaço real, existindo no mundo concreto, sendo sua linguagem o corpo (novamente, segundo Rilke) ${ }^{255}$ e "seu ofício, para o escultor, (...) dar forma a uma força natural que muitas vezes só existia na semente mais profundamente enterrada ou no sentimento mais secretamente oculto"256, é a arte verdadeiramente material, existente no mundo tangível, que poderia representar, assim, de forma mais realista, "a coisa", aquilo que se quer representar. Para contar fielmente o ocorrido no quarto da empregada com a barata, nada melhor do que recorrer, portanto, a essa arte, que é ainda sua arte primeva, transmitindo da forma mais verídica a sua experiência para o leitor. Descrevendo vívida e mimeticamente a barata, detalhando sua corpulência tridimensional, o movimento inerente ao animal e sua interioridade germinante, a partir da écfrase, G.H. consegue, assim, juntar sua arte escultórica com a arte da palavra. Ut pictura poesis, conforme escreveu Horácio ${ }^{257}$ : como a pintura é a poesia. Por que não, então, como a escultura é a prosa?

\subsection{Exercícios ecfrásticos na Paixão}

Era uma cara sem contorno. As antenas saíam em bigodes dos lados da boca. A boca marrom era bem delineada. Os finos e longos bigodes mexiam-se lentos e secos. Seus olhos pretos facetados olhavam. Era uma barata tão velha como um peixe fossilizado. Era uma barata tão velha como salamandras e quimeras e grifos e leviatãs. Ela era antiga como uma lenda. Olhei a boca: lá estava a boca real. (...)

E eis que eu descobrira que, apesar de compacta, ela é formada de cascas e cascas pardas, finas como as de uma cebola, como se cada uma pudesse ser levantada pela unha e no entanto sempre aparecer mais uma casca, e mais uma. Talvez as cascas fossem as asas,

\footnotetext{
${ }^{255}$ Ibidem, p. 27.

${ }^{256}$ CALDAS, Daniela. "Introdução". In: RILKE, Rainer Maria. Rodin. Rio de Janeiro: Relume-Dumará, 1995, p. $10-11$.

${ }^{257}$ HORÁCIO. Op. cit.
} 
mas então ela devia ser feita de camadas e camadas finas de asas comprimidas até formar aquele corpo compacto.

Ela era arruivada. E toda cheia de cílios. Os cílios seriam talvez as múltiplas pernas.

Os fios de antena estavam agora quietos, fiapos secos e empoeirados. A barata não tem nariz. Olhei-a, com aquela sua boca e seus olhos: parecia uma mulata à morte. Mas os olhos eram radiosos e negros. Olhos de noiva. Cada olho em si mesmo parecia uma barata. O olho franjado, escuro, vivo e desempoeirado. E o outro olho igual. Duas baratas incrustadas na barata, e cada olho reproduzia a barata inteira. (...)

A matéria da barata, que era o seu de dentro, a matéria grossa, esbranquiçada, lenta, crescia para fora como de uma bisnaga de pasta de dentes.

Diante de meus olhos enojados e seduzidos, lentamente a forma da barata ia se modificando à medida que ela engrossava para fora. A matéria branca brotava lenta para cima de suas costas como uma carga. Imobilizada, ela sustentava por cima do flanco empoeirado a carga do próprio corpo. (...)

A grossura branca imobilizara-se agora por cima das cascas. Olhei para o teto, descansando um pouco os olhos que eu sentia terem se tornado fundos e grandes. ${ }^{258}$

Retomando a descrição da barata, pode-se afirmar que sua função, no texto, é, acima de tudo, dar ao leitor a experiência que G.H. teve, mostrando de forma mais detalhada possível o que ela vira, para que ela possa, assim, livrar-se da vivência terrível e seguir sua nova vida, enfim. É por esse motivo, de oferecer ao leitor a exata imagem de sua visão, a partir de uma caracterização mais pormenorizada possível do inseto (a partir, é claro, dos olhos de G.H. e de sua reflexão proposta no relato), que tal passagem pode ser considerada não só uma mera descrição, mas uma espécie de retomada de um recurso retórico bastante utilizado na antiguidade: a écfrase.

Retenha-se a complexidade do significado da palavra grega:

ekphrasis (de phrazô, "fazer entender", e ek, "até o fim") significa "exposição" ou "descrição" (...). Aélio Theon diz que ekphrasis é discurso periegético - que narra em torno - pondo sob os olhos com enargeia, "vividez", o que deve ser mostrado. Nos seus Progymnasmata, Hermógenes a define de maneira semelhante: técnica de produzir enunciados que têm enargeia, presentando a coisa quase como se o ouvido a visse em detalhe. ${ }^{259}$

Alguns autores clássicos também se ocuparam em definir o conceito, colocando-o como um tópico da retórica que faria revelar aos olhos do leitor/ouvinte aquilo que se quer descrever:

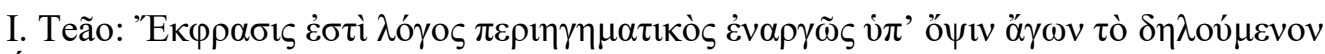
Écfrase é um discurso vividamente percursivo [ou periegemático] que traz o que é revelado diante dos olhos.

\footnotetext{
258 PSGH, p. 44-61.

${ }^{259}$ HANSEN, João Adolfo. "Categorias epidíticas da ekphrasis". Revista USP, São Paulo, n. 71, set/nov 2006, p. 85 .
} 


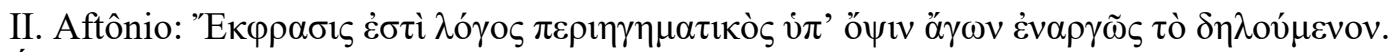
Écfrase é um discurso percurssivo [ou periegemático] que traz vividamente o que é revelado diante dos olhos.

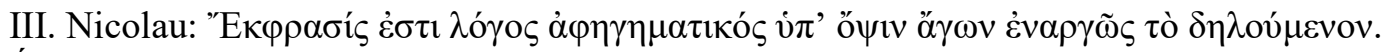
Écfrase é o discurso condutivo [dirigido ou afegemático] que traz vividamente o que é exibido diante dos olhos.

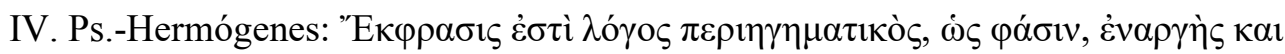

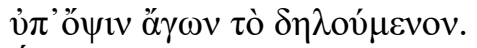

Écfrase é um discurso percursivo [ou periegemático], como dizem, palpável [ou visível] que

traz o que é revelado diante dos olhos. ${ }^{260}$

Percurtir ou conduzir: essas seriam as atribuições do discurso ecfrástico, que, portanto, "conduz exegeticamente os olhos da mente do interlocutor ao derredor de objetos, e espaços, e gentes, e circunstâncias, e às vezes, e máquinas, e pinturas, e esculturas, observados de acordo com os sentidos do hermeneuta, do sofista, do rétor, ou do poeta que

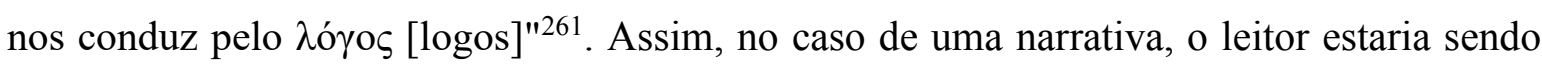
transportado, pelo narrador, a certa visão, certa imagem, de forma que este escolhe o objeto e/ou a cena a serem descritos e o modo como vai descrevê-los ao seu público, elaborando um "comando ecfrástico":

o enunciador se propõe textualmente como alguém que irá dirigir o enunciatário pelos bosques da ficção, ou melhor, pelos caminhos e descaminhos da narrativa. Sua posição de superioridade advém de sua condição de hermeneuta, de exegeta. Converte-se o enunciador ecfrástico nos olhos do enunciatário. Soma o narrador em si mesmo os olhos que lhe são próprios, os do "eu" e os que lhe são alheios, os do "tu" discursivo. A sobreposição desses dois níveis é capaz de gerar a visão totalizadora e minuciosa que se quer descrever com a

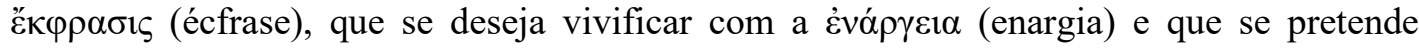
clarificar com a $\sigma \alpha \phi \eta ́ v \varepsilon 1 \alpha$ (clareza). Em segundo lugar, o exegeta ao ocupar o lugar de comando no percurso descritivo (...) assomando a sua visualidade com a visualidade de seu "exército", de seus seguidores faz seu discurso ganhar validação argumentativa, já que de saída coopta o enunciatário a ver com seus olhos. ${ }^{262}$

Portanto, parece que tanto a visão do narrador sobre a écfrase quanto a do leitor que a receberá (sobrepondo, assim, enunciador e enunciatário) são constituintes fundamentais para se ter uma "visão totalizadora" do objeto ou da cena descritas. Dessa forma, reforça-se o intuito principal da écfrase como colocado pelos estudiosos gregos: o de mostrar ao outro

\footnotetext{
${ }^{260}$ MARTINS, Paulo. "Uma visão periegemática sobre a écfrase". Revista Clássica, v. 29, n. 2, 2016, p. 180.

${ }^{261}$ Ibidem, p. 177.

262 Ibidem, p. 180-181.
} 
aquilo que se viu de forma mais fiel e viva possível, a fim de suscitar nele as mesmas sensações e emoções tidas pelo enunciador - eis o objetivo de G.H.:

o enunciador ecfrástico de uma obra de arte, portanto, ignora a natureza estática e espacial da pintura, do relevo, do mosaico ou da tapeçaria e relata "os acontecimentos descritos como se estivessem se desdobrando no tempo", como que imprimindo à imago o envolvimento emocional ou patético do descritor, do enunciador ecfrástico. ${ }^{263}$

[a écfrase] deve evocar na mente do leitor ou do espectador uma imagem ausente, para provocar nele uma resposta de impacto emocional. Seu aspecto performativo, aliado à sua energia narrativa, "faz ver" com tanta vivacidade que o leitor praticamente "escuta" o texto. ${ }^{264}$

Considerando, ainda, a perspectiva de Luís Quintais a respeito desse recurso, mostrase intrigante pensar o aspecto levantado por ele ${ }^{265}$ : "a ekphrasis resulta de uma inquietação, uma reiteração de um 'mistério' muito particular" ${ }^{266}$. Inquietação que G.H. demonstra sentir ao se deparar com o inseto e, depois, descrevê-lo no relato - e que Quintais afirma ser suscitada, pensando na definição de écfrase como uma representação verbal de uma representação visual (aspecto que será melhor discutido adiante), graças à impossibilidade de transporte entre modalidades artísticas diferentes:

O que importa aqui reter será tão-só o seguinte: a ekphrasis é uma representação de outra representação, logo ela radica numa faculdade meta-representacional que se encontra largamente distribuída entre os humanos. Não é, pois, exclusivo da arte. Ela é seguramente uma propriedade que podemos detectar em tudo aquilo a que chamamos de criações humanas. Sendo uma representação verbal de uma representação visual, dir-se-ia que a ekphrasis trabalha esse hiato entre formas de representação diferenciadas. Celebra a impossibilidade de transporte, mas ironicamente procura uma consistência, afirmando, afinal, o mistério ou a inquietação ou o desassossego dessa impossibilidade. ${ }^{267}$

Pensando, então, a barata como uma escultura verbal, pode-se pensar, de certa maneira, essa celebração, a partir da incomum união de uma arte à outra. $\mathrm{O}$ desassossego parece ser duplo: pela não compreensão de G.H. acerca do episódio que vivera, com a barata, esforçando-se para entender toda a experiência; e pela inviabilidade dessa descrição introduzir, de fato visualmente, o inseto no relato por meio da mediação da palavra, fazendo,

\footnotetext{
${ }^{263}$ Ibidem, p. 170, meus grifos. Interessante a descrição de Martins da écfrase fazer se desdobrar no tempo a imagem descrita: nota-se, assim, como essa retórica parece, de fato, unir arte do tempo e arte do espaço.

264 VIEIRA, Miriam de Paiva. "Écfrase: de recurso retórico na antiguidade a fenômeno midiático na contemporaneidade". Todas as Letras. São Paulo, v. 19, n. 1, jan./abr. 2017, p. 54.

265 Devo essa sugestão a Veronica Stigger.

${ }^{266}$ QUINTAIS, Luís. "A ekphrasis como meta-representação". Relâmpago: Revista de poesia. Lisboa, n. 23, out. 2008 , p. 94.

${ }^{267}$ Ibidem, p. 95.
} 
assim, o leitor realmente vê-lo tal qual a personagem o vira. Dessa forma, o leitor (ou o ouvinte) apenas pode imaginar, a partir da descrição ecfrástica, como seria o objeto descrito, mas não visualizá-lo verdadeiramente.

Além disso, a écfrase também poderia ser tida como uma espécie de digressão na obra literária:

ela é, portanto, um parêntesis na estrutura da narração, uma suspenção de seu vetor progressivo, um desvio ou um retardamento do fluxo textual, uma antecipação de eventos ou uma recuperação de elementos que compõem o $\mu \tilde{0} \theta \mathrm{o}$, a fim de estruturar ou reestruturar a narração, temporal, temática ou figurativamente numa sequência necessária e útil. Características essas que, parece-me, aproximam-na da própria ideia de digressio ou egressio, digressão, em conformidade com as lições de Cícero e de Quintiliano. ${ }^{268}$

Pensando a descrição da barata uma écfrase, e sendo essa possível de ser categorizada como uma digressão, pode-se afirmar que o trecho de apresentação do inseto também seria, portanto, uma digressão. Ainda, pode-se ir além neste pensamento e considerar, de certa maneira, toda a narrativa de G.H. como uma longa digressão ecfrástica: em sua escrita, a personagem recua na narrativa, moldando-a e desmoldando-a, suspendendo-a frequentemente para depois tentar progredir até retardar novamente o movimento, estruturando e "reestruturando a narração (...) numa sequência necessária e útil"269, que dá forma ao relato da protagonista. O movimento espiralado da narrativa de G.H. poderia ser, assim, resultado desse subterfúgio que, aparentemente, não permite o pleno desenvolvimento da narrativa - e que também imita, a sua maneira, o fazer escultórico, como se analisará adiante.

Curiosamente, além de ser um recurso retórico e possuir todas essas acepções, a écfrase também servia como "epigrama que acompanhava esculturas e relevos em suas bases, descrevendo seus conteúdos como forma complementar de linguagem. (...) Eram, portanto, originariamente, breves legendas que se aplicavam em "traduzir" estátuas, de acordo com Elsner, belas e enigmáticas" 270 . Écfrase e a arte da escultura se encontravam, então, juntas. O recurso não servia apenas para "fazer entender até o fim" algum objeto, a partir da descrição verbal na fala ou na escrita, pondo sob os olhos do leitor ou ouvinte com enargeia e mimesis aquilo que se quer mostrar, mas que não está presente; mas servia, sobretudo, para acompanhar estátuas belas e enigmáticas, complementando sua linguagem essencialmente

\footnotetext{
268 MARTINS, 2016, p. 169.

269 Ibidem.

270 Ibidem, p. 165, meus grifos.
} 
visual com informações verbais. Para cada escultura elaborada, tinha-se então sua legenda. G.H. parece fazer algo semelhante, porém singular: ao mesmo tempo em que descreve mimética e energicamente, em detalhe, a barata agonizante, a escultura verbal do inseto vai nascendo e tomando forma. Escultura e descrição se originam conjuntamente na narrativa, uma vez que, como já explanado, a estátua da barata não existe no plano real de G.H. (apesar do inseto ter, de fato, um espaço próprio na sua realidade), mas é formada verbalmente a partir do desejo da protagonista de colocar a sevandija aos olhos do leitor, relatando sua experiência e sua visão.

Desse modo, resumidamente:

O factor crucial do exercício ecfrástico, tal como foi previsto pela retórica e pela poética clássicas é, não o objecto de que o discurso se ocupa (que não precisa sequer de ser um objeto, e muito menos de ter uma existência referencial), mas o modo como o objecto é dado a ver, já que a ekphrasis, figura por excelência da enargeia, tem a sua origem no desejo semiótico pelo signo natural, isto é, na ambição de obter the world captured in the word (Krieger), pelo que a própria constelação retórica dos exercícios descritivos os liberta, ab initio, da tarefa reprodutiva de um objecto que lhes seja extrínseco; é portanto a visão como ficção que está em causa. ${ }^{271}$

A visão como ficção, justamente, que aparece como exercício ecfrástico em G.H.: apesar da descrição escultórica da barata, dada a ver ao leitor, possuir alguns componentes aparentemente não miméticos (porém, mesmo assim, vívidos), que a caracterizam de acordo com a perspectiva de G.H. sobre o inseto - os "olhos de noiva", "a boca real" - essas caracterizações podem obedecer ao que Joana Matos Frias diz ser

uma superação qualitativa do visível pelo visualizável, o princípio ecfrástico originário promove o vínculo dialéctico entre o eidos (ideia) e o eidolon (imagem), quer dizer, entre a visão interior e a visão exterior (a palavra em guerra com o olhar, "uma visão liberta das limitações da visão": "não uma forma de dizer, mas uma forma transcendente de ver", na síntese de Blanchot), e por conseguinte entre o desenho interno da consciência e o desenho externo do mundo e seus objectos: olhar é menos a faculdade de recolher imagens do que a de estabelecer uma relação (Starobinski), pelo que a écfrase só é mimética enquanto acto imaginativo, também na justa medida em que a evidência é cosa mentale, figura do pensamento (schemata dianoias). ${ }^{272}$

Novamente a discussão sobre o reproduzir versus o expressar pode vir à tona com a écfrase: a "visão como ficção", a mimese "enquanto ato imaginativo", podem caracterizar a

\footnotetext{
${ }^{271}$ FRIAS, Joana Matos. "Écfrase: 10 aporias". Elyra - Revista da Rede Internacional Lyracompoetics, v. 8, n. 12/2016, p. 33-34.

${ }^{272}$ Ibidem, p. 34.
} 
reprodução artística tal qual Alfredo Bosi a descreveu. Reproduzir ecfrasticamente e, portanto, mimeticamente, passa pelo fato de que o ato será imitativo de acordo com o sujeito que descreve o objeto. Não há reprodução que imite total e verdadeiramente a realidade. A imagem passará pela visão humana, sendo ela transformada por essa, por mais que se queira a reprodução artística fidedigna, tentando copiar a realidade efetiva na obra. Daí os termos: ideia da barata pós-experiência, e imagem dela; o que foi visível de sua aparência e o que foi visualizável pelos olhos parciais de G.H.. A mimética ecfrástica é, assim, oblíqua - afinal, o que configurariam concretamente em um semblante de uma barata os "olhos de noiva" e uma "boca real"? -, apenas ato imaginativo: essa é a realidade que G.H. viu e transformou em narrativa, e não a realidade concreta, pura. Mas não seriam esses detalhes que impediriam a descrição de ser caracterizada como ekphrasis - ainda mais quando todo o resto do relato descritivo parece de fato poderoso o bastante para constituir uma visão daquilo que é escrito: uma barata com os olhos pretos, compacta, seus cílios se mexendo, depois as antenas paradas, em seu corpo formado de diversas camadas, grosso e cortado ao meio, permitindo que saia aos poucos, "como uma bisnaga de pasta de dentes", sua massa esbranquiçada.

No entanto, partindo da significação como exercício retórico da antiguidade cujo objetivo era dar a ver algo não presente, com base na enargeia e na mimesis (seja ela real ou imaginativa), é importante verificar como é considerada a écfrase na crítica da modernidade. James Heffernan, coletando diversos textos de diversas épocas que poderiam definir a ekphrasis, foi um dos estudiosos que procurou propor um novo conceito para o longevo termo:

Se écfrase é definida como um modo, a definição deve ser afiada o suficiente para identificar certo tipo de literatura e ainda, também, elástico o bastante para alcançar do classicismo ao pós-modernismo, de Homer a Ashbery. O que eu proponho é uma definição simples em sua forma, mas complexa em suas implicações: écfrase é a representação verbal de uma representação gráfica.

Essa definição exclui uma boa parte do que alguns críticos incluiriam como ekphrasis (...). Isso também nos permite distinguir a écfrase de duas outras formas de associar a literatura das artes visuais - pictorialismo e iconicidade. O que distingue essas duas da écfrase é que cada uma objetiva, primariamente, representar objetos naturais e artificiais ao invés de obras de arte representativas. ${ }^{273}$

\footnotetext{
273 "If ekphrasis is to be defined as a mode, the definition must be sharp enough to identify a certain kind of literature and yet also elastic enough to reach from classicism to postmodernism, from Homer to Ashbery. What I propose is a definition simple in form but complex in its implications: ekphrasis is the verbal representation of graphic representation. This definition excludes a good deal of what some critics would have ekphrasis include (...). It also allows us to distinguish ekphrasis from two other ways of mingling literature and the visual arts - pictorialism and iconicity. What distinguishes those two things from ekphrasis is that each one aims primarily to represent natural objects and artifacts rather than works of representational art." (tradução livre,
} 
Portanto, para Heffernan - e muitos outros críticos que acabaram seguindo sua opinião - a écfrase na modernidade não seria mais um recurso amplo de descrição. Agora, a descrição ecfrástica seria apenas aquela em que há a presença, de fato, de uma representação gráfica: pinturas, desenhos, fotografias. Por exemplo, o desenho de Janair, ao ser descrito por G.H.: há aqui, de fato, a representação verbal de uma representação gráfica, de uma expressão visual. Mais especificamente, esse desenho seria classificado como uma "écfrase nocional"274, ou seja, a descrição de uma obra imaginária, não existente na nossa realidade, mas apenas na narrativa clariceana.

G.H. parece querer justamente "representar objetos naturais e artificiais ao invés de obras de arte representativas": a representação da barata, objeto natural, e de sua experiência com ela. Porém, como é possível voltar ao naturalismo, à época representativa que caracteriza momentos como a Idade Clássica e o Renascimento, onde o homem vivia em perfeito equilíbrio com o mundo natural, se a vida na modernidade é caracterizada justamente pela desarmonia e pelo desequilíbrio entre homem e universo ${ }^{275}$ Portanto, o não naturalismo, a abstração, são presentes na arte moderna, na qual "o artista abandona o mundo tridimensional e retorna ao plano, reduz a natureza orgânica, inclusive o homem, a formas geométricas lineares, e frequentemente abandona o mundo orgânico completamente por um outro de linhas, formas e cores puras"276. Toda a descrição - seja o pictorialismo, a iconicidade ou a écfrase - é constituída, em parte, da visão pessoal do autor/narrador, sendo impossível representar, de qualquer forma, a realidade genuína sem considerar a perspectiva do observador que a descreve.

Apesar desse importante estudo de ressignificação da écfrase, cabe uma outra reflexão: segundo Heffernan, a escultura verbal da barata e sua descrição não seriam, então, um exercício ecfrástico, mas um exemplo de Pictorialismo, uma vez que esse é o nome dado por ele ao recurso de exposição detalhada de objetos naturais - enquanto a iconicidade seria de objetos artificiais, conforme suas palavras -:

grifos meus). In: HEFFERNAN, James A. W. "Ekphrasis and Representation". New Literary History, vol. 22, n. 2, 1991, p. 299.

${ }^{274}$ HOLLANDER, John. "The Poetics of Ekphrasis". In: Word and Image, Vol. 4. p. 209-219, 1988, apud HEFFERNAN, 1991, p. 313.

275 Termos utilizados por Joseph Frank em "A forma espacial na literatura moderna". Revista USP, São Paulo, n. 58 , jun./ago. 2003 , p. 238.

${ }^{276}$ Ibidem, p. 237. 
O Pictorialismo gera, na linguagem, efeitos similares àqueles criados por fotografias (...) representando o mundo com a ajuda de técnicas pictoriais: ele não está representando fotografias em si. (...) ao invés disso, há o uso de da equivalência verbal para a precisão pictorial a fim de representar um conjunto de objetos. ${ }^{277}$

G.H. descreve a barata, sua grossura, sua corpulência tridimensional, suas cascas, suas antenas, seus cílios, seus movimentos e afins. De fato, podemos ter uma espécie de retrato da barata neste momento em que ela, cortada ao meio pelo golpe do guarda-roupa, agoniza e deixa seu de-dentro se exteriorizar. Todavia, visto todo o esforço verbal que G.H. exerce para essa descrição fidedigna (com traços imaginários, frutos de seu próprio olhar sobre esse outro), também se pode considerar a passagem em questão como um exercício ecfrástico nos moldes retóricos da Antiguidade, já que há certa "'exposição' ou 'descrição', associando-se às técnicas de amplificação de tópicas narrativas" ${ }^{278}$ a partir de um narrador que "expõe a coisa por meio da opinião sobre a coisa, com autoridade, clareza e nitidez, apresentando-a com enargeia"279 e parecendo aplicar "preceitos previstos pela instituição retórica para transformar o ouvido do ouvinte, constituído na variação elocutiva do discurso, num olho incorporal que os avalia". ${ }^{280}$ Retomando o trecho, nota-se como essas características da écfrase estão presentes, a sua maneira, nas passagens de descrição da barata, caracterizando seus aspectos físicos para o leitor: "Era uma cara sem contorno. As antenas saíam em bigodes dos lados da boca. A boca marrom era bem delineada. Os finos e longos bigodes mexiam-se lentos e secos. Seus olhos pretos facetados olhavam" (...) "apesar de compacta, ela é formada de cascas e cascas pardas, finas como as de uma cebola" (...) "Ela era arruivada. E toda cheia de cílios." (...) "os olhos eram radiosos e negros" (...) "A matéria da barata, que era o seu de dentro, a matéria grossa, esbranquiçada, lenta, crescia para fora como de uma bisnaga de pasta de dentes". Mesmo no pictorialismo, parece haver certa necessidade de uma retórica ecfrástica para se alcançar os efeitos de imitação de uma foto ou de qualquer outra imagem. Portanto, parece possível classificar, de acordo com o conceito retórico de écfrase, a descrição física da barata também como um exercício ecfrástico.

\footnotetext{
${ }^{277}$ Tradução livre: "Pictorialism generates in language effects similar to those created by pictures (...) representing the world with the aid of pictorial techniques: he is not representing pictures themselves. (...) instead, it uses the verbal equivalent of pictorial precision in order to represent a set of objects.". HEFFERNAN, 1991, p. 300. Nota: aqui, penso que o termo "pictures" pode significar tanto as fotografias, representações mais modernas da visão que Heffernan de fato exemplifica em seu texto (com elementos como foco, enquadramento e digitalização), quanto as pinturas, desenhos e outros tipos de imagem em geral.

${ }^{278}$ HANSEN, 2006, p. 85.

${ }^{279}$ Ibidem, p. 87.

${ }^{280}$ Ibidem.
} 
Dessa forma, pode-se aplicar à obra mais um recurso que aproxima arte verbal da arte visual, escultura da literatura. Próprio da antiguidade, a écfrase na Paixão permite a G.H. realizar aquilo que ela mais queria: dar ao leitor, à imagem da mão decepada que ela segurava, uma experiência de sua experiência: "toma essa barata, não quero o que vi" ${ }^{281}$. Dada a escultura verbal da barata graças à sua descrição ecfrástica, a protagonista pode libertar-se, enfim, de sua vivência desestabilizadora. A partir do inseto asqueroso, prenunciada pelo desenho da ex-empregada, sua jornada pelo conhecimento do mundo, do outro e também do autoconhecimento se fortalece e toma rumo na narrativa. A sua prática no mundo artístico como escultora faz com que ela, ao tentar dar forma à sua vivência através do relato na arte literária, possa, por meio dessa travessia tão extraordinária, passar por um processo necessário de formação artística.

\section{8 $O$ inseto versus a empregada; a escultura versus o desenho}

G.H. e Janair possuem uma característica em comum: almejam, em alguma medida, captar o mundo, representá-lo. Enquanto a primeira era de fato uma artista, uma escultora, parecendo traçar sua arte inclusive com a barata, a segunda surpreende a antiga patroa e o leitor ao deixar, inesperadamente, um desenho na parede.

Um dos choques de G.H. pode ser justamente esse: como pode esse sujeito, o outro desconhecido, ter atribuições semelhantes às dela? E é justamente através da arte, esse atributo aparentemente compartilhado pelas duas mulheres, que a perspectiva estrangeira se faz conhecida: "Olhei o mural onde eu devia estar sendo retratada... (...) Havia anos que eu só tinha sido julgada pelos meus pares e pelo meu próprio ambiente que eram, em suma, feitos de mim mesma e para mim mesma. Janair era a primeira pessoa realmente exterior de cujo olhar eu tomava consciência"282.

No começo da jornada, quando G.H. decide limpar a casa, começando pelo quarto da empregada, até ver o mural na parede, a protagonista confessa não se lembrar fisicamente de Janair:

A lembrança da empregada ausente me coagia. Quis lembrar-me de seu rosto, e admirada não consegui - de tal modo ela acabara de me excluir de minha própria casa, como

\footnotetext{
${ }^{281}$ PSGH, p. 56.

282 PSGH, p. 39-40.
} 
se me tivesse fechado a porta e me tivesse deixado remota em relação à minha moradia. A lembrança de sua cara fugia-me, devia ser um lapso temporário. ${ }^{283}$

Até que, graças ao desenho, G.H. vai rememorando aos poucos a mulher:

Mas seu nome - é claro, é claro, lembrei-me finalmente: Janair. E, olhando o desenho hierático, de repente me ocorria que Janair me odiara. Eu olhava as figuras de homem e mulher que mantinham expostas e abertas as palmas das mãos vigorosas, e que ali pareciam ter sido deixadas por Janair como mensagem bruta para quando eu abrisse a porta. (...)

Foi quando inesperadamente consegui rememorar seu rosto, mas é claro, como pudera esquecer? Revi o rosto preto e quieto, revi a pele inteiramente opaca que mais parecia um de seus modos de se calar, as sobrancelhas extremamente bem desenhadas, revi os traços finos e delicados que mal eram divisados no negror apagado da pele.

Os traços - descobri sem prazer - eram traços de rainha. E também a postura: o corpo ereto, delgado, duro, liso, quase sem carne, ausência de seios e de ancas. E sua roupa? Não era de surpreender que eu a tivesse usado como se ela não tivesse presença: sob o pequeno avental, vestia-se sempre de marrom escuro ou de preto, o que a tornava toda escura e invisível - arrepiei-me ao descobrir que até agora eu não havia percebido que aquela mulher era uma invisível. Janair tinha quase que apenas a forma exterior, os traços que ficavam dentro de sua forma eram tão apurados que mal existiam: ela era achatada como um baixorelevo preso a uma tábua. ${ }^{284}$

Janair é descrita, portanto, com um "rosto preto e quieto", a "pele inteiramente opaca", as "sobrancelhas bem desenhadas", os "traços finos" no "negror da pele"; o corpo, por sua vez, "ereto, delgado, duro, liso, quase sem carne, ausência de seios e de ancas", e "achatada como um baixo-relevo preso a uma tábua"; o avental por cima das roupas também escuras, marrons ou pretas, que reforçavam a invisibilidade de Janair para sua antiga patroa - além de assemelhá-la à barata pela cor. Mas também há uma espécie de mimese imaginativa ${ }^{285}$ nessa descrição: os "traços de rainha" - como a "boca real" e os "olhos de noiva" da barata.

Notando essa caracterização física da mulher, pode-se afirmar que, como na caracterização da barata, há uma écfrase: uma descrição que põe Janair aos olhos do leitor, ao passo em que G.H. vai relembrando sua fisionomia. O pictorialismo também pode estar presente aqui, pois, de fato, parece haver um retrato da empregada a partir de seu esboço no entanto, retoma-se a proposta de que, para haver pictorialismo, deve-se haver écfrase, exposição viva e imitativa da realidade.

Apesar, então, de ser mais uma imagem traçada por G.H. em seu relato, tal qual o é a barata, a representação de Janair, além das semelhanças já notadas pela crítica entre ela e a

\footnotetext{
283 PSGH, p. 39.

${ }^{284}$ PSGH, p. 39-40.

285 Retomando Joana Matos Frias, sobre a écfrase que "só é mimética enquanto acto imaginativo" (FRIAS, 2016, p. 34).
} 
habitante do guarda-roupas ${ }^{286}$, possui uma diferença primordial em relação ao inseto: enquanto a empregada era "achatada como um baixo-relevo preso a uma tábua", a barata, como já defendido, era formada por cascas (as quais podiam ser levantadas pelas unhas), e era também compacta e grossa. Uma rasa e achatada, a outra corpulenta; em uma, a falta de volume, e na outra o relevo fundamental, a aparente tridimensionalidade que caracteriza a escultura. Janair parece ser descrita de acordo com sua própria arte, aquela realmente plana, unidimensional, que é composta de traços: o desenho - e a pintura ou a fotografia, que possuem basicamente essas mesmas características. ${ }^{287}$ Além disso, Janair, em sua caracterização, não está disposta em um espaço físico real (como a barata está no quarto), o que também a aproxima da pintura e do desenho, que, conforme já explicitado, não tendo posição no mundo concreto, constrói ou refaz espaços fictícios para sua obra - no caso de Janair, esse espaço nem ao menos é inventado, mas ausente.

Assim como G.H. parece unir, no seu relato, arte do tempo com arte do espaço, o desenho, segundo Mário de Andrade, também aproximaria esses dois aspectos, sendo uma arte intermediária:

Creio ter sido Alain quem chegou até o ponto de afirmar que o desenho não é, de natureza, uma plástica; mas se há exagero de sistema uma afirmativa assim tão categórica, sempre é certo que o desenho está pelo menos tão ligado, pela sua finalidade, à prosa e principalmente à poesia, como o está, pelos seus meios de realização, à pintura e à escultura. É como que uma arte intermediária entre as artes do espaço e as do tempo (...); o desenho é a arte intermediária que se realiza por meio do espaço, pois a sua matéria é imóvel.

Mas o desenho, da mesma forma que as artes da palavra, é essencialmente uma arte intelectual, que a gente deve compreender com os dados experimentais, ou melhor, confrontadores, da inteligência. É fácil de provar este caráter antiplástico do desenho. Ele é, ao mesmo tempo, um delimitador e não tem limites, qualidades antiplásticas por excelência. Toda escultura, toda pintura, sendo um fenômeno material, nos apresenta um fato fechado,

\footnotetext{
${ }^{286}$ Conforme notou Oliveira: "A comparação da descrição de Janair (...) com a barata, evidencia a identificação de uma com a outra. Janair, a mulata, é da cor da barata. Tem "o rosto preto e quieto (...) a pele inteiramente opaca". A roupa acentua essa semelhança na cor. "Janair vestia-se sempre de marrom escuro ou de preto, o que a tornava toda escura e invisível" (1985, p. 47).

${ }^{287}$ Cita-se, aqui, Joseph Frank: "na arte do século XX, o artista abandona o mundo tridimensional e retorna ao plano" (Op. cit., p. 237). Parece haver uma oposição entre arte moderna e arte naturalista (como o autor denominou as artes que representavam o mundo objetivo e tridimensional, reproduzindo-o de maneira mais real) na oposição da caracterização de Janair e da barata: aquela seria plana, aproximando-se da arte moderna de fato e podendo até levar essa perspectiva contemporânea à G.H.; esta seria tridimensional, em uma provável tentativa de G.H. de constituir o mundo ainda de forma fidedigna em sua obra, naturalista e, portanto, mais próxima da reprodução de fato. Ainda, a característica apalainda de Janair também poderia remontar à arte primitiva, da qual seu desenho se assemelha. Dessa forma, parece possível pensar que Janair poderia já estar em desarmonia com a sociedade à sua volta, como pode demonstrar seu desenho e sua caracterização, enquanto G.H. ainda estava buscando um equilíbrio, mesmo que falso, entre ela e o mundo. A recorrência à arte escultórica, tridimensional por si própria, pode ser um indício de que a protagonista de fato tentava reproduzir o mundo orgânico em sua arte, mesmo em um momento moderno de impossibilidade do mesmo. Janair parece ser, portanto, a peça chave que levará primeiramente a escultora à sua libertação social e, consequentemente, artística.
} 
que se constrói de seus próprios elementos interiores inteiramente desrelacionando com o que para a estátua ou para o quadro seria o não-eu. ${ }^{288}$

Esse fato aberto que seria o desenho, algo intermediário entre tempo e espaço, necessitando tanto da imobilidade espacial quanto da intelectualidade humana, é a arte da invisível e subjugada empregada, o outro de classe cuja perspectiva G.H. desconhecia. Enquanto G.H. lida com uma arte desrelacionada do eu, Janair produz um modo de expressão que "é uma espécie de definição (...). Ele [o desenho] é uma espécie de provérbio. Exprime, da mesma forma que o provérbio, uma experiência vivida e transformada numa definição eminentemente intelectual" 289 . A partir, então, dos análogos hieróglifos na parede, Janair define a vida de G.H. a partir da sua experiência vivida enquanto trabalhava com ela - como já explicitado, fazendo a narradora interpretar que a "vida de homens" que ela levava poderia ter, como designação, o cão, cuja lealdade e domesticação impedem a transgressão das regras assimiladas.

Barata e Janair, a partir de suas caracterizações por G.H., podem, então, funcionar como opostos: a escultura (tridimensional, grossa) em contraposição com o desenho e a pintura (unidimensionais, planos, rasos e achatados). Ainda, uma outra diferença pode ser explorada: Janair, ao ser descrita dessa forma "achatada como um baixo-relevo preso a uma tábua" e, portanto, distorcida da realidade, sem a corpulência tridimensional humana e consequentemente aproximando-se da unidimensionalidade, parece ser captada por meio de uma representação aperspectívica (o que obedece às tendências das artes modernas - tanto a pintura, quanto a literatura e outras artes -, por não haver a simulação da figuração do corpo no espaço, à moda renascentista):

o ser humano, na pintura moderna, é dissociado ou "reduzido" (no cubismo), deformado (no expressionismo), ou eliminado (no não-figurativismo). O retrato desapareceu. Ademais, a perspectiva foi abolida ou sofreu, no surrealismo, distorções e "falsificações". (...) As hipóteses sobre esse curioso fenômeno tendem a considerar provável que a perspectiva seja um recurso para a conquista artística no mundo terreno, isto é, da realidade sensível. É característica típica de épocas em que se acentua a emancipação do indivíduo, fenômeno fundamental da época sofista e renascentista. ${ }^{290}$

A imagem construída por G.H. da ex-empregada, que de algum modo aponta para essa discussão acerca da tendência aperspectívica da arte moderna - sendo deformada, a

\footnotetext{
288 ANDRADE, Mário. "Do desenho". Op. cit..

289 Ibidem, p. 75-76.

290 ROSENFELD, Anatol. "Reflexões sobre o romance moderno". In: Texto/Contexto I. São Paulo: Editora Perspectiva, 1996, p. 77.
} 
ponto de ser vista, depois de invisível, como aplainada -, pode refletir justamente a maior experiência da protagonista em seu relato: desmontar-se, também, para conhecer o outro, superando a distância que há entre ambos:

O abandono da perspectiva mostra ser expressão do anseio de superar a distância entre indivíduo e mundo; distância de que a perspectiva se torna a expressão decisiva no momento em que o indivíduo já não tem a fé renascentista na posição privilegiada da consciência humana em face do mundo, e não acredita mais na possibilidade de, a partir dela, poder constituir uma realidade que não seja falsa e "ilusionista". ${ }^{291}$

A perspectiva, então, é perdida na arte moderna, porque, como definiu Rosenfeld, "não há mais nenhum mundo exterior a projetar, uma vez que o próprio fluxo psíquico, englobando o mundo, se espraia sobre o plano da tela"292 (no caso, do livro), sendo ela agora o "símbolo do abismo entre o homem e o mundo"293; dando lugar a uma trajetória que a própria G.H. seguiu, percorrendo os desertos milenares a partir do inseto também milenar:

fugir para um mundo ou uma época em que o homem, fundido com a vida universal, ainda não conquistara os contornos definitivos do eu, em que não se dera ainda o pecado original de "individuação" e da projeção perspectívica. Esse culto do arcaico, esta glorificação do início e do elementar são típicos justamente para as vanguardas mais requintadas. ${ }^{294}$

Nesse sentido, seria instigante pensar que a representação da barata opõe-se à de Janair: a construção do inseto parece obedecer à perspectiva da arte tradicional, que "cria a ilusão do espaço tridimensional"295, caracterizada com seu volume, suas camadas e seus impulsos de vida, opondo-se assim à descrição simples e de "baixo-relevo" da ex-empregada - simplicidade, essa, que pode remeter à perda de sentido, à crise do eu no mundo moderno, ao passo que a perspectiva aludiria à ilusão do sujeito centralizado. Desta maneira, talvez seja possível observar, de algum modo, também no dualismo entre o inseto e Janair, a dualidade entre o perspectivismo e o aperspectivismo, entre a arte tradicional e a moderna, a qual quebra com a ilusão do realismo e busca manifestar e superar, em suas diversas manifestações, a ruptura entre eu e o mundo, entre o indivíduo e o estranho, G.H. e o outro.

O desenho de Janair, ao assemelhar-se ao pré-histórico, pode resgatar justamente essa época pré-perspectívica do homem: simples e achatado na parede, com as figuras

\footnotetext{
291 Ibidem, p. 88.

292 Ibidem, p. 87.

293 Ibidem, p. 88.

294 Ibidem.

295 Ibidem, p. 77.
} 
"agigantadas e atoleimadas", a representação, além de denunciar o modo de vida da protagonista, é o símbolo de uma época que G.H. quer alcançar. No entanto, enquanto o desenho de Janair é, de fato, rústico, remetendo a uma era na qual a arte ainda desconhecia as técnicas de perspectiva, a caracterização aperspectívica de Janair feita por G.H. pode remeter ao desalento do mundo moderno, ao invés do consolo do mundo primitivo que caracteriza a arte da empregada: a perspectiva existe, mas não serve para traçar o retrato de Janair - nem tampouco o do sujeito da modernidade. Pode-se afirmar que, com essa expressão artística rupestre e também aperspectívica - tal qual sua autora -, Janair parece demonstrar já conhecer o que GH. tanto lutou para compreender, guiando-a, por fim, na sua própria travessia do conhecimento, por meio do choque profundo provocado primeiramente por esse desenho.

Mais uma última aproximação entre artes pode ser interessante nesse momento, retomando um apontamento especial de Clarice em suas entrevistas com artistas: o fato de a pintura ou o desenho de um escultor ter como componente distintivo a simplicidade extrema dos traços ${ }^{296}$. Particularidade que também se encontra no desenho de Janair: o material era simplório - "ponta quebrada de carvão. Em alguns trechos o risco se tornava duplo como se um traço fosse o tremor do outro. Um tremor seco de carvão seco." ${ }^{297}$; o traço, além de "grosso", era "malfeito" e "excessivamente firme", sem contar "Os pés simplificados" dos homens, bem como todo o corpo dos três seres que se encontravam ali, os quais podem ser definidos por esse mesmo adjetivo. Ainda, o desenho apresenta outra especificidade: sua incompletude. "O desenho é, por natureza, um fato aberto"298; "o desenho é ilimitado, pois que nem mesmo o traço (...) o delimita" ${ }^{299}$. Por isso, ele parece estar mais perto da arte moderna, cujo sentimento de incompletude acomete tanto o artista na modernidade como a obra que ele cria. O que nos leva de volta aos temas do romance de introversão - o romance que se volta sobre si mesmo e reflete sobre seus meios - e da impossibilidade de representar o mundo moderno:

Talvez a ruptura filosófica mais expressiva da modernidade, no campo da estética, tenha sido a quebra da concepção dualista do mundo, baseada em um sistema de oposições binárias entre realidade e representação. Assim, ao abandono progressivo das interpretações que remetiam a criação artística a modelos formais pré-existentes tanto no mundo

\footnotetext{
296 "sempre achei que o traço de um escultor é identificável por uma extrema simplicidade de linhas". LISPECTOR, 2007, p. 205.

297 PSGH, p. 38.

298 ANDRADE, 1965, p. 72.

${ }^{299}$ Ibidem, p. 74.
} 
suprassensível quanto na natureza, corresponde o desenvolvimento de uma arte abstrata, relacional e imanente. $\mathrm{Na}$ arte moderna, diz Argan, o antigo sistema dualista dá lugar a uma pintura que não quer mais ser representação, e sim "apenas pintura ou ato pictórico", bem como "a uma escultura que quer ser puro ato plástico", e "a uma arquitetura que quer ser mera estruturalidade".

Essa condição de reflexividade da arte moderna está baseada no seu sentido de incompletude, ou seja, no seu "não poder ser senão como ser-no-mundo", na sua existência condicionada à experiência que determina. Daí que, com a perda de modelos e referentes externos, a arte moderna se volte cada vez mais para a explicitação material do seu próprio ato de formalização. ${ }^{300}$

Considerando tais reflexões, seria, pois, Janair também uma artista em potencial? Teria ela consciência de que sua arte se aproxima muito mais da modernidade, apesar do caráter primitivo do desenho, do que a arte de G.H., aparentemente mais tradicional e naturalista? De qualquer forma, segundo a própria Clarice, a forma de desenho de Janair poderia aproximá-la da escultura, o que, de certa maneira, relaciona essas duas mulheres tão diferentes. Janair, então, além de ser colocada na obra a partir da caracterização de G.H. um "unheimliche freudiano, ou seja, esse estrangeiro terrível dentro de nossa própria casa: 'É que ali dentro de minha casa se alojara, a estrangeira, a inimiga indiferente"'301 - pode ser vista, também, como um estranho que é, ao mesmo tempo, congênere de G.H., e é justamente o elemento artístico que as aproxima. O outro tão distinto (inclusive na expressão artística), antes um adversário ignorado e facilmente esquecido, é colocado lado a lado de si, graças à arte. Fato que pode, talvez, ter provocado um primeiro espanto em G.H., anunciando o teor de sua futura vivência no quarto da antiga empregada: "perder o poder fálico sobre o outro, desaprender um olhar viciado sobre as coisas, implodir um edifício bem arrumado e sucumbir ao domínio do desconhecido"302.

\subsection{Nos confins da História: o espaço e o tempo na viagem fantasiosa de G.H.}

E que, agora sim, eu estava realmente no quarto.

Tão dentro dele como um desenho há trezentos mil anos numa caverna. E eis que eu cabia dentro de mim, eis que eu estava em mim mesma gravada na parede.

A passagem estreita fora pela barata difícil, e eu me havia esgueirado com nojo através daquele corpo de cascas e lama. E terminara, também eu toda imunda, por desembocar através dela para o meu passado que era o meu contínuo presente e o meu futuro contínuo - e que hoje e sempre está na parede, e minhas quinze milhões de filhas, desde então até eu, também lá estavam. Minha vida fora tão contínua quanto a morte. A vida é tão

\footnotetext{
300 WISNIK, Guilherme. Dentro do nevoeiro: diálogos cruzados entre arte e arquitetura contemporânea. 2012. 262 p. Tese (Doutorado em Arquitetura e do Urbanismo) - Faculdade de Arquitetura e Urbanismo, Universidade de São Paulo, 2012, p. 41, grifos meus.

301 ROSENBAUM, 2006, p. 147-148.

302 Ibidem, p. 149, grifos meus.
} 
contínua que nós a dividimos em etapas, e a uma delas chamamos morte. Eu sempre estivera em vida, pouco importa que não eu propriamente dita, não isso a que convencionei chamar de eu. Sempre estive em vida. ${ }^{303}$

Após relembrar Janair e encontrar a barata, G.H. vivencia, introspectivamente, todo o episódio desconcertante e hermético que dá origem à narrativa. Uma das inusitadas características dessa experiência é a viagem ilusória da protagonista, que, já transtornada pela ingestão do impuro, percorre, nos confins da História do mundo, alguns dos lugares mais importantes da trajetória humana. Reconhecendo-se no próprio desenho pré-histórico de Janair, G.H., agora, vê a si mesma "como um desenho há trezentos mil anos numa caverna". Pecando com o imundo, ela pode afirmar que, finalmente, estava presente no quarto, de corpo e alma, sem quaisquer distrações mundanas para desviá-la. E, nesse ambiente, a partir dessas condições, a protagonista pôde ter a experiência de atravessar o passado - este, uma lama ainda úmida, viva, permitindo que suas próprias raízes se erguessem para uma superfície finalmente visível; assim ele despertava:

Como chamar de outro modo aquilo horrível e cru, matéria-prima e plasma seco, que ali estava, enquanto eu recuava para dentro de mim em náusea seca, eu caindo séculos e séculos dentro de uma lama - era lama, e nem sequer lama já seca mas lama ainda úmida e ainda viva, era uma lama onde se remexiam com lentidão insuportável as raizes de minha identidade..$^{304}$

No entanto, não é apenas o passado particular da protagonista que se evoca nesse momento. A partir da "destruição de camadas e camadas arqueológicas humanas" ${ }^{305}$, G.H. se depara, sobretudo, com a pré-história de toda a humanidade - ainda consciente de seu presente, reconhecendo-o como o futuro dessa viagem temporal:

Por enquanto, hoje, eu vivia no silêncio daquilo que daí a três milênios, depois de erosado e de novo erguido, seria de novo escadas, guindastes, homens e construções. Eu estava vivendo a pré-história de um futuro. Como uma mulher que nunca teve filhos mas os terá daí a três milênios, eu já vivia hoje do petróleo que em três milênios ia jorrar. ${ }^{306}$

É durante o vislumbre da pré-história humana que G.H. reconhece o início de sua própria jornada solitária e penosa; a qual, pela barata - elemento não apenas asqueroso e condenatório de sua danação, mas também tão pré-histórico quanto essa sua viagem

\footnotetext{
303 PSGH, p. 64, grifos meus.

${ }^{304}$ PSGH, p. 56, grifos meus.

${ }^{305}$ PSGH, p. 69, grifos meus.

${ }^{306}$ PSGH, p. 107, grifos meus.
} 
fantasiosa $^{307}$-, encontra a sua própria ruína humana, iniciando sua paixão: "Desde a préhistória eu havia começado a minha marcha pelo deserto, e sem estrela para me guiar, só a perdição me guiando, só o descaminho me guiando" ${ }^{308}$.

O retorno aos primórdios do tempo, que se amalgama a seu presente e a seu futuro, em contínuo, como afirma a protagonista, é não apenas uma experiência temporal; pelo contrário: o espaço também se mostra como elemento revivido. A protagonista, voltando ao passado da humanidade, revive também os locais mais importantes por onde o homem deu alguns de seus primeiros passos - novamente misturando passado, presente e futuro, amalgamando temporalmente aquilo deslumbrado, como demonstram os trechos:

Além das gargantas rochosas, entre os cimentos dos edifícios, vi a favela sobre o morro e vi uma cabra lentamente subindo pelo morro. Mais além estendiam-se os planaltos da Ásia Menor. Dali eu contemplava o império do presente. Aquele era o estreito de Dardanelos. Mais além as escabrosas cristas. Tua majestosa monotonia. Ao sol a tua largueza imperial.

E mais além, já o começo das areias. $O$ deserto nu e ardente. Quando caísse a escuridão, o frio consumiria o deserto, e nele se tremeria como nas noites do deserto. Mais ao longe, o lago salgado e azul cintilava. Para aquele lado, então devia ser a região dos grandes lagos salgados.

Sob as ondas trêmulas do mormaço, a monotonia. Através das outras janelas dos apartamentos e nos terraços de cimento, eu via um vaivém de sombras e pessoas, como dos primeiros mercadores assírios. Estes lutavam pela posse da Ásia Menor.

$\mathrm{Eu}$ havia desencavado talvez o futuro - ou chegara a antigas profundidades tão longinquamente vindouras que minhas mãos que as haviam desencavado não poderiam suspeitar. Ali estava eu de pé, como uma criança vestida de frade, criança sonolenta. Mas criança inquisidora. Do alto deste edifício, o presente contempla o presente. $\mathrm{O}$ mesmo que no segundo milênio antes de Cristo.

E eu, agora eu já não era mais uma criança inquisidora. Eu crescera, e me tornara tão simples como uma rainha. Reis, esfinges e leões - eis a cidade onde vivo, e tudo extinto. Sobrei, presa por uma das pedras que desabaram. E, como o silêncio julgou a minha imobilidade como sendo a de uma morta, todos esqueceram-se de mim, foram embora sem me retirarem, e, julgada morta, fiquei assistindo. E vi, enquanto o silêncio dos que realmente haviam morrido ia-me invadindo como hera invade a boca dos leões de pedra. (...) $)^{309}$

Para sustentar sem quedas meu ânimo de trabalho, eu procuraria não esquecer que os geólogos já sabem que no subsolo do Saara há um imenso lago de água potável, lembro-me

\footnotetext{
307 "Uma barata tão velha que era imemorial. O que sempre me repugnara em baratas é que elas eram obsoletas e no entanto atuais. Saber que elas já estavam na Terra, e iguais a hoje, antes mesmo que tivessem aparecido os primeiros dinossauros, saber que o primeiro homem surgido já as havia encontrado proliferadas e se arrastando vivas, saber que elas haviam testemunhado a formação das grandes jazidas de petróleo e carvão no mundo, e lá estavam durante o grande avanço e depois durante o grande recuo das geleiras - a resistência pacífica. Eu sabia que baratas resistiam a mais de um mês sem alimento ou água. E que até de madeira faziam substância nutritiva aproveitável. E que, mesmo depois de pisadas, descomprimiam-se lentamente e continuavam a andar. Mesmo congeladas, ao degelarem, prosseguiam na marcha... Há trezentos e cinqüenta milhões de anos elas se repetiam sem se transformarem. Quando o mundo era quase nu elas já o cobriam vagarosas." PSGH, p. 47.

${ }^{308}$ PSGH, p. 136, grifos meus.

${ }^{309}$ PSGH, p. 105-106, grifos meus.
} 
de que li isso; e que no próprio Saara os arqueólogos já escavaram restos de utensílios domésticos e de velhas colonizações: há sete mil anos, eu havia lido, naquela "região do medo" desenvolvera-se uma agricultura próspera. O deserto tem uma umidade que é preciso encontrar de novo. $(. . .)^{310}$

De novo abrasada demais, procurei os grandes lagos azuis onde mergulhei meus olhos ressecados. Lagos ou manchas luminosas do céu. Os lagos não eram feios nem bonitos. E era apenas isso o que ainda aterrorizava o meu humano. Procurei pensar no Mar Negro, procurei pensar nos persas descendo pelos desfiladeiros - mas também nisso tudo não encontrei nem beleza nem feiúra, apenas as infinitas sucessões de séculos do mundo. (...) $)^{311}$

Sentei-me de novo na cama. Mas agora, olhando a barata, eu já sabia de muito mais.

Olhando-a, eu via a vastidão do deserto da Líbia, nas proximidades de Elschele. A barata que lá me precedera de milênios, e também precedera aos dinossauros. Diante da barata, eu já era capaz de ver ao longe Damasco, a cidade mais velha da terra. No deserto da Líbia, baratas e crocodilos? Eu estivera o tempo todo sem querer pensar no que já realmente pensara: que a barata é comível como uma lagosta, a barata era um crustáceo.

E só tenho nojo do rastejar de crocodilos porque não sou crocodilo. Tenho horror do silêncio cheio de escamas estratificadas do crocodilo.

Mas o nojo me é necessário assim como a poluição das águas é necessária para procriar-se o que está nas águas. O nojo me guia e me fecunda. Através do nojo, vejo uma noite na Galiléia. A noite na Galiléia é como se no escuro o tamanho do deserto andasse. A barata é um tamanho escuro andando. ${ }^{312}$

A maioria dos locais vislumbrados na paixão são contraditoriamente históricos e genéricos, guardam a ancestralidade dos segredos do mundo e da gênese humana: a Ásia Menor, vista por muitos historiadores como berço da civilização, sendo ocupada desde a préhistória, com seus lagos e desertos; o estreito de Dardanelos e a visão de uma sociedade acabada, com seus reis, leões e esfinges abandonados às heras que crescem e as encobrem com a passagem do tempo; bem como todos os outros locais que também são parte dessa região: o Saara; o Mar Negro; a Líbia, seu deserto de Elschele; Damasco, colocado pela própria protagonista como "uma das cidades mais velhas da terra"; a Galileia, enfim, lar de Cristo durante boa parte de sua vida ${ }^{313}$.

\footnotetext{
310 PSGH, p. 109, grifos meus.

311 PSGH, p. 111, grifos meus.

312 PSGH, p. 113, grifos meus.

313 Oliveira percebe esse caráter da viagem, apontando também outras referências:
}

As inúmeras alusões a objetos, fatos e lugares associados com o passado, dos mitos sobre a origem do homem, à Pré-História e à Antiguidade, até a Idade Média e o Renascimento, contribuem para a impressão de contínuo mergulho no tempo: o jardim do Paraíso, o dilúvio, dinossauros, trogloditas, o deserto da Líbia e a cidade de Elschele, as milenares civilizações do Saara, os primeiros mercadores assírios, reis, esfinges e leões, o segredo dos faraós, escrínios, sarcófagos, esfinges, minaretes, o estreito de Dardanelos, Atenas no seu apogeu, a cidade de Constantinopla, o retrato de Mona Lisa. (1985, p. 26) 
Essa imago mundi que acomete G.H., mesmo que em devaneio, com a rememoração de um tempo passado - amalgamado, aqui, ao presente e ao futuro -, tão distante, e de espaços igualmente longínquos, ocupa um lugar relevante na trajetória de sua paixão. A viagem ilusória da protagonista parece ser um dos principais elementos da narrativa que dão ao romance o seu caráter mítico, atributo já evidenciado pela crítica. Ou seja, a partir da recordação e, mais além, de uma espécie de revivescência da ascendência humana dentro do quarto da empregada, pode-se notar o alicerce do "mito da busca da origem" em G.H., que "seria uma das temáticas fundamentais de Clarice, revestido, entre outras formas, pela procura obstinada da 'vida em si mesma', núcleo tão caro aos romancistas modernos"314.

A experiência de G.H. a faz perceber que "a vida não é o que eu pensava e sim outra como se antes eu tivesse sabido o que era!" 315 . No início do relato, a protagonista já se descreve como alguém que não vivera, ainda, a sua própria tragédia, e que via a si mesma apenas da forma como os outros - semelhantes a ela - viam-na e a descreviam:

A G.H. vivera muito, quero dizer, vivera muitos fatos. Quem sabe eu tive de algum modo pressa de viver logo tudo o que eu tivesse a viver para que me sobrasse tempo de... de viver sem fatos? de viver. Cumpri cedo os deveres de meus sentidos, tive cedo e rapidamente dores e alegrias - para ficar depressa livre do meu destino humano menor? e ficar livre para buscar a minha tragédia.

Minha tragédia estava em alguma parte. Onde estava o meu destino maior? um que não fosse apenas o enredo de minha vida. A tragédia - que é a aventura maior - nunca se realizara em mim. Só o meu destino pessoal era o que eu conhecia. E o que eu queria.

Em torno de mim espalho a tranquilidade que vem de se chegar a um grau de realização a ponto de se ser G.H. até nas valises. Também para a minha chamada vida interior eu adotara sem sentir a minha reputação: eu me trato como as pessoas me tratam, sou aquilo que de mim os outros vêem. Quando eu ficava sozinha não havia uma queda, havia apenas um grau a menos daquilo que eu era com os outros, e isso sempre foi a minha naturalidade $\mathrm{e}$ a minha saúde. E a minha espécie de beleza. Só meus retratos é que fotografavam um abismo? Um abismo. Um abismo de nada. Só essa coisa grande e vazia: um abismo. ${ }^{316}$

É, inicialmente, o desenho de Janair e, depois, a barata - ambas figuras do outro, finalmente seu dessemelhante, que foram tão desconhecidos e desconsiderados pela protagonista até então - que acendem a chama da curiosidade em G.H. e a levam, enfim, à sua tragédia, ao seu destino maior. A ânsia por conhecer essa vida outra, bem como o desejo profundo pelo autoconhecimento e pelo conhecimento do mundo, suplantando esse abismo

\footnotetext{
${ }^{314}$ ROSENBAUM, 2006, p. 22. Rosenbaum ainda prossegue, citando Clarice: "Quero pintar uma tela branca. Como se faz? É a coisa mais difícil do mundo. A nudez. O número zero. Como atingi-los? Só chegando, suponho, ao núcleo último da pessoa".

315 PSGH, p. 11.

316 PSGH, p. 24-25.
} 
que ela já identificava em si mesma, fazem-na provar o insosso da barata, para se chegar ao seu núcleo, ao seu neutro; e, posteriormente, levam-na a cumprir sua caminhada devaneante pela origem humana. Tal é o processo que a permite chegar ao elemento mítico da "vida em si mesma", ao núcleo da sua própria vida; é a isso que G.H. dá o nome de ritual - que é, afinal, a sua trajetória da paixão:

Quando uma pessoa é o próprio núcleo, ela não tem mais divergências. Então ela é a solenidade de si própria, e não tem mais medo de consumir-se ao servir ao ritual consumidor - o ritual é o próprio processar-se da vida do núcleo, o ritual não é exterior a ele: o ritual é inerente. A barata tem o seu ritual na sua célula. O ritual - acredita em mim porque acho que estou sabendo - o ritual é a marca do Deus. ${ }^{317}$

G.H. descobre, então, que o processo do ritual é inerente ao núcleo. Parece que sua experiência de conhecimento do neutro do mundo assemelha-se, de certa forma, à escultura, conforme ela caracteriza: "desgastar pacientemente a matéria até gradativamente encontrar sua escultura imanente" ${ }^{318}$. Assim como o fazer escultórico, para ela, seria simplesmente encontrar a forma natural do objeto (novamente, o "corpo da Vênus" em si, sem dar-lhe uma expressão artística), a própria trajetória da paixão seria também uma descoberta do seu próprio âmago. G.H. parece, assim, buscar captar, no seu ritual, sua própria escultura imanente, sua própria forma humana, mesmo que para isso, para que ela possa chegar a seu próprio neutro, ela tenha que se desumanizar.

\subsection{A obsessão pela "forma"}

Nota-se, portanto, que a experiência de G.H., conforme ela própria aponta desde o início, não fora simples, e, consequentemente, não seria fácil de se transmitir a um outro, representado pela mão decepada que a acompanha durante a narrativa. O relato é tão árduo quanto o próprio rito passional: há de se atravessar, mental e verbalmente, a mesma experiência mais uma vez, para que ela seja, enfim, exposta ao leitor.

Por conseguinte, um dos esforços de G.H. é tentar achar a melhor maneira para se comunicar como escritora. Qual forma dar ao ocorrido? Qual forma dar à sua posterior narrativa? Não à toa, a própria palavra "forma" é repetida diversas vezes, a maioria delas no início da narrativa, antes da protagonista se dedicar propriamente a contar a experiência:

\footnotetext{
317 PSGH, p. 115-116.

318 PSGH, p. 25, grifos meus.
} 
Mas é que também não sei que forma dar ao que me aconteceu. E sem dar uma forma, nada me existe. E - e se a realidade é mesmo que nada existiu?! Quem sabe nada me aconteceu? Só posso compreender o que me acontece mas só acontece o que eu compreendo - que sei do resto? O resto não existiu. Quem sabe nada existiu! Quem sabe me aconteceu apenas uma lenta e grande dissolução? E que minha luta contra essa desintegração está sendo esta: a de tentar agora dar-lhe uma forma? Uma forma contorna o caos, uma forma dá construção à substância amorfa - a visão de uma carne infinita é a visão dos loucos, mas se eu cortar a carne em pedaços e distribuí-los pelos dias e pelas fomes - então ela não será mais a perdição e a loucura: será de novo a vida humanizada.

A vida humanizada. Eu havia humanizado demais a vida.

Mas como faço agora? Devo ficar com a visão toda, mesmo que isso signifique ter uma verdade incompreensível? ou dou uma forma ao nada, e este será o meu modo de integrar em mim a minha própria desintegração? Mas estou tão pouco preparada para entender. Antes, sempre que eu havia tentado, meus limites me davam uma sensação física de incômodo, em mim qualquer começo de pensamento esbarra logo com a testa. Cedo fui obrigada a reconhecer, sem lamentar, os esbarros de minha pouca inteligência, e eu desdizia caminho. Sabia que estava fadada a pensar pouco, raciocinar me restringia dentro de minha pele. Como, pois, inaugurar agora em mim o pensamento? E talvez só o pensamento me salvasse, tenho medo da paixão.

Já que tenho de salvar o dia de amanhã, já que tenho que ter uma forma porque não sinto força de ficar desorganizada, já que fatalmente precisarei enquadrar a monstruosa carne infinita e cortá-la em pedaços assimiláveis pelo tamanho de minha boca e pelo tamanho da visão de meus olhos, já que fatalmente sucumbirei à necessidade de forma que vem de meu pavor de ficar delimitada - então que pelo menos eu tenha a coragem de deixar que essa forma se forme sozinha como uma crosta que por si mesma endurece, a nebulosa de fogo que se esfria em terra. E que eu tenha a grande coragem de resistir à tentação de inventar uma forma. ${ }^{319}$

Há uma profunda necessidade de G.H. em dar forma ao amorfo, ao inferno que era a "destruição de camadas e camadas arqueológicas humanas" ${ }^{320}$, a sua desumanização e a perda do seu mundo conhecido até aquele momento; e igualmente infernal poderia ser o núcleo tão desejado por ela: "Foi assim que fui dando os primeiros passos no nada. Meus primeiros passos hesitantes em direção à vida, e abandonando a minha vida. O pé pisou no ar, e entrei no paraíso ou no inferno: no núcleo." ${ }^{321}$ Uma vez que o inferno seria o aniquilamento do eu - tornado nada além da vida por si só, assim se desumanizando -, o inexpressivo, que caracteriza toda a sua vivência, é, para a protagonista, também "diabólico"322. A expressão pela palavra - que aqui se caracteriza, basicamente, pela tentativa de dar forma à desmedida experiência, tarefa que exigiria imensa bravura: "Terei que ter a coragem de usar um coração

\footnotetext{
319 PSGH, p. 12-13, grifos meus.

320 PSGH, p. 69.

${ }^{321}$ PSGH p. 80. Mesmo o paraíso é caracterizado como amorfo: "e entrar por essa coisa sem forma que é um paraíso. Um paraíso que não quero!". Ibidem, p. 16.

322 PSGH, p. 100.
} 
desprotegido e de ir falando para o nada e para o ninguém?"323 - mostra-se necessária à protagonista, nem que seja apenas para comunicar como todo o acontecimento fora inaudito e indizível: "Uma cólera inexplicável, mas que me vinha toda natural, me tomara: eu queria matar alguma coisa ali"324; "A hora de viver é tão infernalmente inexpressiva que é o nada"325; "Vou agora te contar como entrei no inexpressivo que sempre foi a minha busca cega e secreta"326; "Estou tentando te dizer de como cheguei ao neutro e ao inexpressivo de mim"327; "o neutro é inexplicável e vivo"328; "o quarto já se tornara de um familiar inexprimível" ${ }^{329}$; "Como te falar do inexpressivo?"330.

Assim, o problema da dificuldade em expressar sua experiência, acompanhada da necessidade de contá-la a alguém, pode ser resumido pelas próprias palavras de G.H.: "A palavra e a forma serão a tábua onde boiarei sobre vagalhões de mudez" ${ }^{\prime 3}$. A narrativa da paixão de G.H. parece semelhante às bolinhas de pão que a protagonista esculpia na mesa do café da manhã, fazendo triângulos a partir delas: "uma forma que é feita de suas formas opostas" $^{332}$. Retomando Emília Amaral:

essa realidade indizivel, que no entanto passional e apaixonadamente ela não abre mão de dizer, só pode ser expressa de modo negativo, ou seja, por meio daquilo que ela não é: os sentimentos, os atributos, os valores humanos e sobretudo a linguagem e a forma. Assim, $o$ processo narrativo faz-se pelo avesso, configurando uma espécie de anti-romance, que, por sua vez, parece pedir um anti-leitor. ${ }^{333}$

É importante relembrar que, segundo G.H., é exatamente a escultura que a teria dado o prazer e a necessidade pela "forma das coisas" - transportada, depois, dessa arte visual à arte da palavra, para relatar o indizível:

Também da escultura intermitente ficara-me o hábito do prazer, a que por natureza eu já tendia: meus olhos tanto haviam manuseado a forma das coisas que eu fora aprendendo cada

\footnotetext{
323 PSGH, p. 13.

324 PSGH, p. 43, grifos meus.

325 PSGH, p. 78, grifos meus.

326 PSGH, p. 97, grifos meus.

327 PSGH, p. 99, grifos meus.

328 PSGH, p. 101, grifos meus.

329 PSGH, p. 103 grifos meus.

330 PSGH, p. 142, grifos meus.

331 PSGH, p. 18.

332 PSGH, p. 29. G.H. nota que essa sua ação mecânica e inconsciente poderia ter uma significado, apesar de não saber propriamente qual: "Se isso me tinha um sentido, o miolo de pão e meus dedos provavelmente sabiam" (Ibidem).

333 AMARAL, 2005, p. 46, grifos meus.
} 
vez mais o prazer, e enraizando-me nele. Eu podia, com muito menos do que eu era, eu já podia usar tudo: exatamente como ontem, à mesa do café, me bastava, para formar formas redondas de miolo de pão, a superfície de meus dedos e a superfície do miolo de pão. ${ }^{334}$

Pois é justamente essa obsessão pela forma que a leva a arrumar o quarto da empregada - a forma, agora, é transportada para a atividade doméstica, a organização do lar:

Levantei-me enfim da mesa do café, essa mulher. Não ter naquele dia nenhuma empregada iria me dar o tipo de atividade que eu queria: o de arrumar. Sempre gostei de arrumar. Suponho que esta seja a minha única vocação verdadeira. Ordenando as coisas, eu crio e entendo ao mesmo tempo. Mas tendo aos poucos, por meio do dinheiro razoavelmente bem investido, enriquecido o suficiente, isso impediu-me de usar essa minha vocação: não pertencesse eu por dinheiro e por cultura à classe a que pertenço, e teria normalmente tido o emprego de arrumadeira numa grande casa de ricos, onde há muito o que arrumar. Arrumar é achar a melhor forma. Tivesse eu sido empregada-arrumadeira, e nem sequer teria precisado do amadorismo da escultura; se com minhas mãos eu tivesse podido largamente arrumar. Arruma a forma? 335

Consequentemente, seria possível inferir que essa sua compulsão é o atributo que a faz passar por todo seu processo da paixão, de deformação humana; o que a guia, posteriormente, à narrativa, a fim de reencontrar sua forma ao reviver, pelo relato, o ocorrido: "tenho que fazer o esforço de pelo menos me dar uma forma anterior para poder entender o que aconteceu ao ter perdido essa forma" ${ }^{336}$.

Novamente, nesta citação, nota-se a diferenciação entre dom e vocação: G.H. afirma que sua vocação era a de arrumar, e que, se não pertencesse à classe social a qual ela pertencia, teria sido empregada-arrumadeira. Já no momento em que esculpe as bolinhas de pão, ela diz que "para ter o que eu tinha eu nunca precisara nem de dor nem de talento. O que eu tinha não me era conquista, era dom" ${ }^{337}$. E complementa, refletindo: "Só tive a facilidade dos dons, e não o espanto das vocações - é isso?" ${ }^{338}$. De fato, de acordo com G.H., ela parecia possuir a aptidão necessária à arte das formas concretas, a escultura; mas ainda não havia tido o chamado, efetivamente, desse seu talento. Curiosamente, a vocação que ela enxergava em si era apenas a das atividades com o lar: a limpeza e a organização do apartamento. Apesar de, nesse romance, a protagonista mulher já ser independente financeiramente e ter sua própria moradia (a qual, como já visto, apresenta-se mais libertadora e menos opressora ao

\footnotetext{
${ }^{334}$ PSGH, p. 28, grifos meus.

${ }^{335}$ PSGH, p. 32, grifos meus.

336 PSGH, p. 23.

${ }^{337}$ PSGH, p. 28.

${ }^{338}$ PSGH, p. 28.
} 
sexo feminino), G.H. parece insistir, ainda que minimamente, no papel das tarefas caseiras que a mulher teria; sobretudo, no papel da mulher de classe média/alta, que não poderia seguir sua vocação porque a tarefa da arrumação estaria diretamente relacionada à condição financeira - no caso, Janair teria sido a última responsável pela arrumação do apartamento, justamente essa mulher diferente da protagonista, "realmente exterior" ${ }^{339}$, caracterizada como sendo de uma classe social mais baixa que a de G.H..

Parecia, então, que a "própria tragédia" que faltava à protagonista (e que é sua paixão, como visto) poderia ser, também, a do chamado para a arte - no caso, escultórica, até então caracterizada apenas como um dom e um amadorismo; para que, assim, essa arte quiçá seja, finalmente, uma vocação, tal qual a organização da casa. G.H. precisaria, aparentemente, desprender-se de uma possível última regra social que ainda a confinava no seu papel como mulher (de classe média): o entremear da arrumação doméstica, ofício atribuído ao sexo feminino, e da impossibilidade de segui-la para fora de seu próprio lar devido à sua classe social.

A urgência de viver sua própria tragédia constitui, então, uma espécie de paradoxo: G.H., que tanto carecia das formas de sua vida (a arrumação diária, a escultura, a brincadeira na mesa com os miolos de pão, por exemplo; além da sua própria forma como humana, que havia sido abalada logo pelo desenho de Janair e, depois, por toda a experiência com o inseto), reconhece que, para realizar seu desejo de viver seu destino maior e suplantar seu abismo interior, ela deveria passar pela própria "transformação de crisálida em larva úmida" ${ }^{340}$ : perdendo o que ela, até então, reconhecia como sua forma humana, nunca antes rejeitada por ela, mas sempre a servindo de apoio, de "terceira perna" - "Quem, como eu, sabia que nunca havia mudado de forma desde o tempo em que me haviam desenhado na pedra de uma caverna?"341 -; abandonando, corajosamente, esse formato pré-conhecido; desumanizando-se para, enfim, reconhecer o que seria a verdade do homem e cumprir seu destino humano:

O mistério do destino humano é que somos fatais, mas temos a liberdade de cumprir ou não o nosso fatal: de nós depende realizarmos o nosso destino fatal. Enquanto que os seres inumanos, como a barata, realizam o próprio ciclo completo, sem nunca errar porque eles não escolhem. Mas de mim depende eu vir livremente a ser o que fatalmente sou. Sou dona de minha fatalidade e, se eu decidir não cumpri-la, ficarei de fora de minha natureza

\footnotetext{
${ }^{339}$ PSGH, p. 40.

${ }^{340}$ PSGH, p. 74, grifos meus. Nota-se, aqui, que a transformação da protagonista é também invertida: é a crisálida que virará larva, e não o contrário; é o humano que se transformará no seu oposto, seu original, desumanizando-se.

${ }^{341}$ PSGH, p. 95.
} 
especificamente viva. Mas se eu cumprir meu núcleo neutro e vivo, então, dentro de minha espécie, estarei sendo especificamente humana.

- Mas é que tornar-se humano pode se transformar em ideal e sufocar-se de acréscimos... Ser humano não deveria ser um ideal para o homem que é fatalmente humano, ser humano tem que ser o modo como eu, coisa viva, obedecendo por liberdade ao caminho do que é vivo, sou humana. E não preciso cuidar sequer de minha alma, ela cuidará fatalmente de mim, e não tenho que fazer para mim mesma uma alma: tenho apenas que escolher viver. Somos livres, e este é o inferno. ${ }^{342}$

Aprendendo que o destino humano é a liberdade de cumprir sua fortuna, G.H. aprende que a busca pela "vida em si mesma" (usando novamente as palavras de Rosenbaum) é o reconhecimento de que, na verdade, ela não teria que fazer para ela própria uma alma, incorporando, quase forçosamente, sua forma humana, imutável desde a pré-história que ela conhecera pela sua viagem ilusória e pelo desenho hieroglífico de Janair: para chegar ao núcleo de si e da vida, ela só precisaria ter a liberdade de viver, sem quaisquer impedimentos e sem quaisquer formas pré-definidas.

A antiga forma de G.H., que a deixava apoiada em sua "terceira perna", era justamente a "aparência de uma vida tranquila, independente, mundana, estável, situada no topo da hierarquia social (ela mora num apartamento de cobertura)" ${ }^{343}$; por consequência, o abandono dessa forma na sua experiência relatada resulta no "desmoronamento do sistema" ${ }^{344}$, no "início de uma ruptura não apenas com essa maneira de viver, mas com a engrenagem - com o sistema geral dos hábitos mundanos"345. A qual tem, por principal fruto, a desumanização: "a personagem desprende-se do mundo e experimenta, após gradual redução dos sentimentos, das representações e da vontade, a perda do eu" ${ }^{346}$. Uma importante lição a respeito de sua obsessão pelas formas, essencialmente mundanas e civilizatórias, é também aprendida por G.H.: ela, que "nunca havia deixado minha alma livre, e me havia organizado depressa em pessoa porque é arriscado demais perder-se a forma" ${ }^{\prime 347}$, reconhece que a verdadeira forma de ser efetivamente humana e de se chegar ao núcleo da vida é pela amorfa e inexpressiva liberdade -

(...) a verdadeira tragédia está na inexorabilidade do seu inexpressivo, que é a sua identidade nua.

\footnotetext{
342 PSGH, p. 124.

343 NUNES, 1995, p. 60.

${ }^{344}$ Ibidem.

${ }^{345}$ Ibidem, p. 61.

${ }^{346}$ Ibidem, p. 63

${ }^{347}$ PSGH, p. 146, grifos meus.
} 
Às vezes - às vezes nós mesmos manifestamos o inexpressivo - em arte se faz isso, em amor de corpo também - manifestar o inexpressivo é criar. No fundo, somos tão, tão felizes! pois não há uma forma única de entrar em contato com a vida, há inclusive as formas negativas! inclusive as dolorosas, inclusive as quase impossíveis - e tudo isso, tudo isso mesmo antes de morrer, tudo isso mesmo enquanto estamos acordados! $!^{348}$

Para G.H., "manifestar o inexpressivo" - que é a experiência com o neutro - é criar artisticamente. Novamente, aqui, pode-se retomar a discussão clariceana em torno dos termos "representação" e "expressão". G.H., no início do relato, diz tentar, pela escrita, "mais uma reprodução do que uma expressão" ${ }^{349}$ : como já dito, tocar o núcleo por meio da arte. A reformulação dos termos por Clarice, como já analisado, pode ter, aqui, uma espécie de solução: nem representação, nem expressão, mas talvez a iminência de uma nova categoria artística, a inexpressividade como possibilidade de se chegar ao it. O pensamento clariceano, assim, apesar de tomar emprestado os termos tradicionais para remodelar seus significados de acordo com seus desejos artísticos, parece, enfim, coerente: uma vez que esses mesmos termos não traduzem corretamente o seu anseio, usar a ideia de "inexpressividade" parece uma boa saída para tentar nomear a quimera de Clarice (e de G.H.) em reproduzir na arte "a própria forma do corpo" ao invés da "expressão dada ao corpo" ${ }^{350}$; ou a própria experiência de se tocar o núcleo da vida ao invés de uma expressão artística do vivido.

\subsection{1 À maneira das bonecas russas}

Toda essa experiência de G.H. apresenta como uma de suas características o uso dos sentidos, por vezes extremados. Deles, nessa narrativa, notam-se principalmente o paladar a ingestão da barata - e a visão - o desenho de Janair, a aparência da ex-empregada, a barata, a viagem ilusória. Este último é o que caracteriza, em essência, tanto a arte de G.H., a escultura, quanto a própria escrita clariceana, conforme Pontieri: "A gênese da escritura clariciana se dá como simultaneidade e/ou cruzamento de visão e oralidade" ${ }^{351}$.

Em A paixão segundo G.H., o relato dessa experiência sobretudo visual da protagonista passa, então, pela sua necessidade em dar-lhe uma forma - ou, usando as palavras de Clarice: "o conteúdo luta para se formar" ${ }^{352}$. G.H. nota, pela visão, todas as

\footnotetext{
348 PSGH, p. 142, grifos meus.

349 PSGH, p. 19.

${ }^{350}$ Retomando a crônica "Uma porta abstrata", já citada anteriormente.

${ }^{351}$ PONTIERI, 2001, p. 223.

${ }^{352}$ LISPECTOR, 1999, p. 254.
} 
formas do seu mundo exterior: Janair ${ }^{353}$, a barata ${ }^{354}$, a sua viagem ilusória pelos confins da trajetória humana ${ }^{355}$, e inclusive a imagem de si mesma, que, além de ser formada apenas pelo que os outros semelhantes a ela achavam, é colocada na narrativa através dos seus retratos. Essas suas fotografias, nas quais G.H. reconhece o mistério de sua individualidade e essência, dariam, junto com a escultura, uma espécie de pré-clímax de sua experiência: "Talvez tenha sido esse tom de pré-clímax o que eu via na sorridente fotografia malassombrada de um rosto cuja palavra é um silêncio inexpressivo, todos os retratos de pessoas são um retrato de Mona Lisa." ${ }^{356}$ Todos esses elementos, como já demonstrados até aqui, foram caracterizados na narrativa pelos olhos de G.H., transformando-se em palavra - alguns deles a partir da figura de retórica, a écfrase, como já apontado.

No entanto, esses elementos que a levam a sua experiência relatada são, como já evidenciado, frequentemente mostrados por G.H. como "inexpressivos", "inexplicáveis", "inexprimíveis", "indizíveis". É o que Pontieri chama, ao fazer alusão às fotografias nas obras de Clarice, de "signo da falta e do incapturável" ${ }^{357}$. Em A paixão segundo G.H., não só os retratos da protagonista são assim caracterizados ${ }^{358}$, mas, aparentemente, tudo o que ela vê durante a experiência da paixão e que a conduz, enfim, a entrar no seu núcleo, no neutro, no território do inarrável.

$\mathrm{Na}$ vivência do núcleo da vida, portanto, o amorfo parece tomar conta dos seres. Por isso, a acentuada dificuldade de G.H. em narrar e em achar uma forma adequada para a narrativa. Entretanto, nota-se que a narrativa dessa personagem acaba por apresentar sua forma peculiar de fluência: a repetição.

Já muito analisada pela crítica, a narrativa de G.H. se inicia e se fecha com a repetição de seis travessões; e, dentre eles, há uma narrativa em que cada capítulo se inicia com a última frase do capítulo anterior ${ }^{359}$. Por isso, frequentemente denominam-na como circular ou espiralada - como é possível de se notar nos textos críticos destacados no início deste capítulo

\footnotetext{
353 "Janair tinha quase que apenas a forma exterior, os traços que ficavam dentro de sua forma eram tão apurados que mal existiam: ela era achatada como um baixo-relevo preso a uma tábua" (PSGH, p. 40, grifos meus); com os já notados "traços de rainha", a postura ereta e magra e a pele negra.

${ }^{354}$ Com suas cascas, o corpo compacto, os cílios e antenas, a face com seus olhos de noiva que serviam de espelhamento de si, como já explorado anteriormente.

${ }^{355}$ Vendo, percebendo os lugares, principalmente da Ásia menor, pelos quais os homens deram seus primeiros passos, com também já explorado.

${ }^{356}$ PSGH, p. 26, grifos meus.

${ }^{357}$ PONTIERI, 2001, p. 81.

358 "Olhava de relance o rosto fotografado e, por um segundo, naquele rosto inexpressivo o mundo me olhava de volta também inexpressivo" (PSGH, p. 24).

359 Olga de Sá propôs um diagrama para demonstrar melhor esse formato da narrativa. Ele estará inserido nos anexos.
} 
-: para avançar na narrativa, há antes um movimento de retorno. Eis a forma encontrada para o relato; ou, eis como o conteúdo encontra sua própria maneira de se formar.

Conforme já notado por Nunes, essa estrutura da repetição que se vê reiteradamente no romance denuncia o próprio caráter inexpressivo da paixão de G.H.:

Qualquer que seja o nível alcançado pelo processo, maximamente extensivo, as repetições servem para contrastar, na própria rede do discurso que elas geram, o testemunho da experiência pura com a verbalização que possibilita evocar essa experiência, já distanciada ou transcendida, e que não possui conteúdo representativo. ${ }^{360}$

Essa "falta de conteúdo representativo" leva, também como apontado nos trechos citados por Nunes e inseridos a seguir, à repetição de palavras dentro dos capítulos da narrativa - recurso usado incansavelmente no relato -, reforçando o caráter inexpressivo da experiência ao não conseguir caracterizar propriamente tudo aquilo que vira e aquilo que ela vai dizer:

Eu vi. Sei que vi porque não dei ao que vi o meu sentido. Sei que vi - porque não entendo. Sei que vi-porque para nada serve o que vi (PSGH, 15).

$V i$, com a falta de compromisso de quem não vai contar nem a si mesmo. Via, como quem jamais precisará entender o que viu. Assim como a natureza de uma lagartixa vê, sem ter depois sequer que lembrar. A lagartixa vê-como um olho solto vê (PSGH, 106).

Vou te dizer o que nunca te disse antes, talvez seja isso o que está faltando: ter dito. Se eu não disse, não foi por avareza de dizer, nem por minha mudez de barata que tem mais olhos que boca. Se eu não disse é porque não sabia que sabia - mas agora sei (PSGH, 117). ${ }^{361}$

Pela falta de "conteúdo representativo", isto é, pela matéria da paixão pertencer justamente ao campo do inenarrável, todas essas repetições servem para encaminhar a narrativa para o seu silêncio final; e, de certa maneira, acabam reforçando-o:

Em A paixão segundo G.H., a repetição subverte a lógica do discurso, entendido este como sendo um conjunto de representações ordenadas. Ou melhor: o discurso se desenvolve aumentando e mostrando a irrepresentabilidade das coisas. Se assim é, a repetição, que interfere com a lógica do discurso, não só aumenta a área de silêncio das palavras. Também constitui uma preparação ao silêncio em que finalmente o dizer expressivo mergulha. Neste sentido, haveria, além do silêncio hiperbólico que a retórica distingue, uma espécie de silêncio enfático produzido pela recorrência intensificadora tanto de termos e frases quanto, especificamente, das conexões lógicas do discurso, incluindo-se entre elas a própria negação. ${ }^{362}$

\footnotetext{
${ }^{360}$ NUNES, 1995, p. 140, grifos meus.

361 Apud NUNES, 1995, p. 140.

362 Ibidem, p. 140-141, grifos meus.
} 
Assim, a forma encontrada por G.H. para compor seu relato denuncia exatamente o conteúdo que ela tanto deseja contar: "a irrepresentabilidade das coisas", o amorfo do neutro, a inexprimível experiência da paixão.

Essa estrutura narrativa da repetição se assemelha, a sua maneira, à imagem da barata e da viagem ilusória de G.H.. Pontieri já notou a semelhança entre o inseto e a imago mundi vivenciada pela narradora:

a imagem da superposição de envoltórios define a estrutura folheada não só da casca da barata, como ainda da aventura de G.H. desenterrando arqueologicamente as camadas de sentido psíquico, cultural e biológico, desconstrução pela qual se opera, ao mesmo tempo, a reconstrução de sentidos novos. ${ }^{363}$

Do mesmo modo, Oliveira compara as diferentes "camadas" encontradas nessa obra clariceana:

O recurso mais evidente é a estruturação de várias imagens concatenadas, de forte efeito expressionista, tendo como denominador comum o fato de partirem todas de um objeto de muitas camadas: os vários andares do edifício onde G.H. mora; as camadas arqueológicas estratificadas da terra, revelando vestígios das civilizações sucessivas; as cascas de uma cebola e as dezenas de camadas de tecidos que a biologia revela existir até nas antenas da barata.

O traço comum a essas imagens, tão importantes para a estruturação da obra (...), articula-se com o tratamento da forma narrativa e também das categorias de tempo e de espaço: todas elas são marcadas pela sugestão da multiplicidade na unidade. ${ }^{364}$

Portanto, nota-se que superposição pode definir, também, a própria forma da narrativa: as repetições das frases finais de cada capítulo dão ao relato uma espécie de estrutura de encaixe. Conforme descrito por Alonso: "a massa textual assinala a intersecção en abyme de encadeamentos significativos diversos, um intrigante jogo narrativo especular, percorrendo um itinerário poético e labiríntico"365.

Alonso nota em A paixão segundo G.H. uma estrutura denominada mise en abyme ${ }^{366}$, que é, justamente, a técnica narrativa da repetição interna e dos encadeamentos suscitados por ela:

\footnotetext{
363 PONTIERI, 2001, p. 94.

364 OLIVEIRA, 1985, p. 15.

365 ALONSO, Mariângela. "Dimensões especulares em A paixão segundo G.H., de Clarice Lispector". Revista do Sell, 2014, vol. 4, n. 2, p. 1.

366 Mesma técnica especular que pode se observar na descrição dos olhos da barata. Relembrando: "Duas baratas incrustadas na barata, e cada olho reproduzia a barata inteira". (PSGH, p. 45).
} 
Trata-se de uma das formas mais empregadas pela Literatura no intento de refletir sobre si mesma, ou seja, um processo de auto-reflexão, denominado mise en abyme pelo escritor André Gide (...).

A imagem en abyme que seduz Gide é oriunda da heráldica e representa um escudo contendo em seu centro uma espécie de miniatura de si mesma, de modo a indicar um processo de profundidade e infinito, o que parece sugerir, no campo literário, noções de reflexo, espelhamento.

O entendimento do vocábulo perpassa na escala de personagens da obra literária, o redobramento do próprio sujeito da narrativa, num movimento reflexivo:

[...] constitui um enunciado que se refere a outro enunciado - e, portanto, uma marca do código metalinguístico; enquanto parte integrante da ficção que resume, torna-se o instrumento dum regresso e dá origem, por consequência, a uma repetição interna. (Dallenbach 1979:54)

Este procedimento de resumo intratextual ou "repetição interna", conforme apontado por Dallenbach, constitui-se como a desarticulação da massa textual, intervindo na rede de relações de forma a assinalar a intersecção de encadeamentos significativos diversos, isto é, um interessante jogo de espelhos inserido na narrativa. ${ }^{367}$

Dessa maneira, nota-se que há uma semelhança entre as camadas do corpo da barata, as camadas arqueológicas desenterradas por G.H. durante a paixão e as camadas resultantes da própria forma da narrativa, a repetição. Tal sistema de encaixe na escrita foi denominado por Todorov de "os homens-narrativas", ou simplesmente "narrativas de encaixe". No caso de A paixão segundo G.H., pode-se notar, na verdade, o que o autor chama de "autoencaixe, isto é, quando a história encaixante se encontra, num quinto ou sexto grau, encaixada por ela mesma"368. Não há novas histórias sendo encaixadas à história de G.H. - como acontece, por exemplo, com As mil e uma noites, obra tomada por Todorov para o estudo desse tipo de narrativa -; pelo contrário: é a própria paixão que é contada (ou, melhor, que a protagonista tenta contar, uma vez que é inenarrável) repetidamente, encadeando-se em si mesma o tempo todo no relato. Adiciona-se ainda, à narrativa da experiência da paixão, a própria reflexão da protagonista sobre o seu drama da linguagem - como é possível notar principalmente no início da narrativa, como já demonstrado, com os questionamentos da narradora a respeito de que forma dar ao ocorrido, como narrar a sua vivência -, o que dá à obra de G.H.. duas pautas diferentes sendo narradas ao mesmo tempo: "uma pauta do discurso que versa sobre o tema da arte e da linguagem - pauta transversal à outra, parateológica, contendo a prática

367 ALONSO, Mariângela. "Um enredamento de baratas: a mise en abyme em 'A quinta história', de Clarice Lispector". Estação Literária, Londrina, v. 7, 2011, p. 58.

368 TODOROV, Tzvetan. "Os homens-narrativas". In: As estruturas narrativas. São Paulo: Perspectiva, 2006, p. 124. 
meditativa sobre Deus e a existência"369. É o que caracteriza Todorov como "a narrativa de uma narrativa", outra característica do encaixe:

o encaixe é uma explicitação da propriedade mais profunda de toda narrativa. Pois a narrativa encaixante é a narrativa de uma narrativa. Contando a história de uma outra narrativa, a primeira atinge seu tema essencial e, ao mesmo tempo, se reflete nessa imagem de si mesma; a narrativa encaixada é ao mesmo tempo a imagem dessa grande narrativa abstrata da qual todas as outras são apenas partes ínfimas, e também da narrativa encaixante, que a precede diretamente. Ser a narrativa de uma narrativa é o destino de toda narrativa que se realiza através do encaixe. ${ }^{370}$

Essa reflexão da "imagem de si mesma" produz um espelhamento contínuo na narrativa. O que pode apontar outra peculiar característica dos homens-narrativa - ou simplesmente do mise en abyme -: sua aparente infinitude. Esse tipo de narrativa lembra a estrutura das "bonecas russas (matryoshkas) e das caixas chinesas, acopladas umas dentro das outras, em sinal de infinita retomada" ${ }^{371}$. Todorov também caracteriza de maneira semelhante: "se antes da primeira narrativa há 'contou-se', depois da última haverá 'contarse-á"'"'372. Em A paixão segundo G.H., apesar do silêncio para o qual todo o relato caminha, os travessões finais que repetem e se relacionam com os iniciais constituem a narrativa espiralada, cíclica, do "eterno retorno"373: o contar-se-á final retoma o que já se contou. Assim como a escultura verbal da barata espelhava a si mesma através de seus olhos, reproduzindo-se, portanto, infinitamente ${ }^{374}$, a narrativa de G.H. parece seguir os mesmos passos: em cada capítulo, reproduz-se a própria obra a partir da repetição dos termos que findavam o capítulo anterior; e a partir, também, dos travessões que iniciam e finalizam o relato. Tudo isso resulta, a sua maneira, em uma forma de reincidência aparentemente semelhante à do inseto transformado em arte.

\footnotetext{
369 NUNES, 1995, p. 72.

370 TODOROV, 2006, p. 125, grifos meus.

371 ALONSO, 2014, p. 6, grifos meus.

372 TODOROV, 2006, p. 132.

373 "O texto é semelhante a um novelo narrativo em que escrever equivale a procurar. O conto volta, o homem volta, as baratas voltam, instituindo obsessivamente o eterno retorno". ALONSO, 2011, p. 65.

374 Relembrando: "cada olho reproduzia a barata inteira" (PSGH, p. 55).
} 


\subsection{Da forma escultórica à forma narrativa}

De Dante, Rodin chegou a Baudelaire. Aqui não havia nenhum julgamento, nenhum poeta que elevasse com as mãos uma sombra aos céus; um homem, dos mais sofredores, elevara sua voz e elevou-se acima do mais alto de tudo, para o alto, como se para salvar-se de um declínio. Nesses versos havia pontos que destacavam-se da escrita, que não pareciam escritos, mas moldados; eram palavras e grupos de palavras que se fundiam nas mãos quentes do poeta, linhas que eram sentidas como relevos e sonetos, que como coluna com capitéis confusos, traziam a carga de um impacto do pensamento. Ele sentia de todo modo obscuro que de onde essa arte repentinamente acabava, logo uma outra tomava impulso e ele já podia experimentar o desejo dessa outra arte. Ele via em Baudelaire um antepassado, alguém que não teria se deixado enganar pelas faces e que buscava os corpos, onde a vida era maior, mais selvagem e sem calma. ${ }^{375}$

A estrutura de encaixe que caracteriza a narrativa de G.H. pode lhe conferir, assim, certo aspecto visual: tal qual as camadas da barata ${ }^{376}$, os encadeamentos internos do relato as suas próprias "camadas" da escrita - podem dar à narrativa uma melhor (e mais fácil) visibilidade dela mesma ${ }^{377}$; além de seu caráter espiralado, que é próprio, também, do campo visual, e que dá, como já notado, uma imagem de infinitude, como se a narrativa estivesse fechada nela mesma, contínua e eternamente, sem possibilidade de discernir seu começo do seu fim:

o retorno das frases concretiza o movimento restaurador da pulsão, ao mesmo tempo em que presentifica e possibilita a emergência de novos significados na mesma expressão verbal. $\dot{E}$ o eterno retorno modificado. (...)

Lembremos das cantigas medievais, que construíram as estrofes sempre com o último verso da anterior, recurso conhecido como leixa-pren. Esse aproveitamento, aqui, parece estar a serviço de estabelecer uma tal continuidade entre as partes, que não seja mais possivel discriminar o início e o fim. ${ }^{378}$

Do mesmo modo que Rodin caracteriza a escrita de Baudelaire como moldada, semelhantemente às "colunas com capitéis confusos", assim poderia ser vista também a escrita de A paixão segundo G.H.. Sua configuração espiralada poderia lembrar as formas desses capitéis não simples, não lisos, mas "confusos", provavelmente mais elaborados -

\footnotetext{
375 RILKE, 1995, p. 34, grifos meus.

${ }^{376}$ Vale relembrar o trecho: "ela é formada de cascas e cascas pardas, finas como as de uma cebola, como se cada uma pudesse ser levantada pela unha e no entanto sempre aparecer mais uma casca, e mais uma" (PSGH, p. 55).

377 Ao notar o esquema feito por Olga de Sá, incluído nos anexos, essa visualidade pela repetição narrativa pode ser melhor observada.

${ }^{378}$ ROSENBAUM, 2006, p. 170, grifos meus.
} 
inclusive, muitos deles, trazendo desenhos espirais -, lembrados pelo escultor para comparar com a escrita do poeta francês. ${ }^{379}$

A narrativa de G.H. demonstra ter, assim, seu desenho próprio, também espiralado e, portanto, aparentemente, sua própria forma visual, seu próprio "capitel confuso" erguido na pilastra-narrativa da contação da experiência. Retomar as frases anteriores de cada capítulo para avançar no relato (o "eterno retorno modificado"); apresentar seis travessões no seu início e no seu fim -

------ estou procurando, estou procurando. $(\ldots)^{380}$

E então adoro. $-381$

-; repetir palavras relacionadas à sua experiência (a visão - sobretudo o verbo "ver") e à sua tentativa de repassá-la ao leitor (o verbo "dizer"); criando, assim, uma estrutura de encaixe entre essas camadas da narrativa. Ao mesmo tempo, como visto, essa forma de narrar ilustra justamente a inexpressividade do ocorrido. Pode-se afirmar que essa vivência de G.H. é uma "experiência inaugural que, por sê-lo, inscreve-se no corpo de uma matéria anterior à forma" ${ }^{382}$. A experiência é anterior à narrativa; a matéria, portanto, é anterior à forma: é essa experiência-matéria o conteúdo que luta para se formar nesse romance. Retomando o desejo de G.H. por contar exatamente a realidade que lhe ocorrera, de tocar no núcleo da vida - e, por isso, sua tentativa intensa para encontrar uma forma artística que possa, da maneira mais perfeita possível, cumprir esse desejo quimérico -, pode-se referir aqui, ainda, ao "imaginário material" de Bachelard referido por Pontieri: há a aspiração, justamente, por "materializar o imaginário"; aspiração a qual é completamente vinculada ao tato, e, por isso, na qual "a arte se constrói como luta da mão que trabalha contra a resistência da matéria"383.

Parece ser esse o movimento da escrita de G.H.: lutar contra a resistência de sua matéria, a experiência que se quer contar; desejar materializar da forma mais real possível o seu imaginário, aquilo que ela vivenciara, que ela vira (e provara - a massa branca da barata), e que estava guardado, ainda, apenas em sua memória. E, conforme Bachelard, citado por Pontieri, esse movimento é essencialmente tátil - tal qual a arte original de G.H., a escultura.

\footnotetext{
${ }^{379}$ Ver imagem nos anexos.

${ }^{380}$ PSGH, p. 9

381 PSGH, p. 170.

382 PONTIERI, 2001, p. 95.

383 Ibidem.
} 
No entanto, para além desse intenso esforço da protagonista em "materializar o imaginário", aproximando-se do elemento tátil conforme refletiu Bachelard, outro aspecto já analisado do relato parece, a sua maneira, traçar uma aproximação entre a narrativa de G.H. e a arte escultórica: "a qualidade extratemporal de seus momentos reveladores" ${ }^{384}$.

Uma das características da experiência da paixão de G.H. é, como já visto, a sua ilusória viagem pelos confins da trajetória humana, após provar a massa branca da barata, entrando finalmente na sua paixão. Nessa viagem, G.H. desvela as camadas arqueológicas humanas, indo em direção ao que ela caracteriza como "o meu passado que era o meu contínuo presente e o meu futuro contínuo" ${ }^{385}$. Os tempos, como visto, amalgamam-se nesse momento. O "mito da busca da origem" ${ }^{386}$, como denominou Rosenbaum, escancara-se. $A$ paixão segundo G.H., graças a esse elemento da viagem histórica e atemporal que se assemelha ao mítico, pode ser definida com as palavras de Joseph Frank: ela conserva "uma justaposição contínua entre aspectos do passado e do presente, de tal modo que ambas são fundidas em uma visão abrangente" ${ }^{387}$ - G.H. parece ir além, incorporando também o futuro, que, na verdade, poderia ser o seu presente, o qual era, como já analisado, a "pré-história de um futuro"388. G.H., nessa viagem, transcende "os limites históricos" (temporal e espacialmente, já que ela vê, do apartamento, toda a Ásia Menor, como analisado), abarcando em sua visão "todas as épocas"389. É a isso que Frank denomina como "forma espacial na narrativa" - característica que, de certa forma, já havia sido prenunciada por Oliveira:

o tempo de G.H. aparece como uma dimensão do espaço. Ele é uma dimensão do prédio onde mora, do qual se poderia dizer, com Proust, a respeito da igreja de Saint-Andre-des-Champs, em Combray, que é "um edifício ocupando (...) um espaço de quatro dimensões, sendo a quarta a do tempo (...)". O quarto em que G.H. medita, e a hora em que o faz, parecem-lhe a mesma coisa: "ali estava eu sem passagem livre, encurralada pelo sol que agora me ardia nos cabelos da nuca, num forno seco que se chamava dez horas da manhã". ${ }^{390}$

Conforme Frank, esse aspecto da espacialização do tempo na narrativa moderna apresenta suas particularidades, que podem, de certa forma, ser aproximadas de algumas características já analisadas aqui sobre $A$ paixão segundo G.H.: em síntese, a abordagem da

\footnotetext{
${ }^{384}$ FRANK, 2003, p. 241.

385 PSGH, p. 64.

${ }^{386}$ ROSENBAUM, 2006, p. 22.

${ }^{387}$ FRANK, 2003, p. 241.

${ }^{388}$ PSGH, p. 107.

${ }^{389}$ FRANK, 2003, p. 241.

${ }^{390}$ OLIVEIRA, 1985, p. 28.
} 
história e dos tempos, vistos em continuum. Interessante que G.H. utiliza a mesma palavra para caracterizar esse seu momento da experiência: "o meu passado que era o meu contínuo presente e o meu futuro contínuo" ${ }^{391}$. Assim, nota-se a unidade atemporal da narrativa, que mistura passado e presente - e, ocasionalmente, futuro, como ocorre com G.H., vendo o seu presente como o futuro do passado revisitado. Consequentemente, há a ausência de tempo histórico, remetendo ao tempo mítico, intemporal - retomando Rosenbaum, nota-se, na narrativa de G.H., o "mito da busca da origem" ${ }^{392}$, procurando alcançar a "vida em si mesma", seu núcleo. Todos esses são atributos que conferem, particularmente ao romance moderno, segundo Frank, a forma espacial:

Através dessa justaposição de passado e presente, (...) a história se torna antihistórica: já não é mais vista como uma progressão objetiva e causal no tempo, com diferenças distintamente marcadas entre cada período, mas é sentida como um continuum em que as distinções entre passado e presente estão obliteradas. Assim como a dimensão de profundidade foi se esvaecendo das artes plásticas, ela também foi se esvaecendo da história à medida que formava o conteúdo dessas obras: passado e presente são vistos espacialmente, encerrados em uma unidade intemporal que, embora possa acentuar diferenças de superfície, elimina qualquer sentimento de seqüência histórica por meio do ato mesmo da justaposição. A imaginação histórica objetiva, da qual o homem moderno tanto se orgulhava e a qual cultivou tão cuidadosamente desde a Renascença, é transformada, nesses escritores, na imaginação mítica para a qual o tempo histórico não existe - a imaginação que vê as ações e os eventos de uma época em particular meramente como novo corpo dado a protótipos eternos. Esses protótipos são criados transmutando-se o mundo temporal da história no mundo intemporal do mito. E é esse mundo intemporal do mito, formando o conteúdo comum da literatura moderna, que encontra sua expressão estética apropriada na forma espacial. ${ }^{393}$

Retomando Rosenfeld, é interessante lembrar que esse retorno ao tempo mítico "solução" para a radicalização do romance psicológico, que entra em crise no século XX parece ser inevitável: ele expressa o "desejo de fugir para um mundo ou uma época em que o homem, fundido com a vida universal, ainda não conquistara os contornos definidos do eu, em que não se dera ainda o pecado original da 'individuação' e da projeção perspectívica"394. Esse desejo representa, em sua visão, um processo do homem, que sempre, de alguma maneira, tentará voltar ao tempo arcaico, de unificação entre eu e mundo:

No fundo e em essência o homem repete sempre as mesmas estruturas arquetípicas - as de Édipo ou de Electra (a própria psicologia recorreu ao mito); as do pecado original, da

\footnotetext{
391 PSGH, p. 64, grifos meus.

392 ROSENBAUM, 2006, p. 22.

393 FRANK, 2003, p. 241.

394 ROSENFELD, 1996, p. 88.
} 
individuação; da partida da casa paterna, da volta do filho pródigo; de Prometeu, de Teseu no labirinto - e assim em diante. A própria emergência e emancipação do indivíduo racional e consciente é apenas parte daquele "eterno retorno", é um padrão fixo que a humanidade repete na sua caminhada circular através dos milênios.

(...) a personalidade individual tinha de desfazer-se e tornar-se abstrata no processo técnico descrito: para que se revelem tanto melhor as configurações arquetípicas do ser humano; estas são intemporais como é intemporal o "tempo mítico" que, longe de ser linear e progressivo (como é o tempo judaico-cristão), é circular, voltando sobre si mesmo. O tempo linear, cronológico, se apaga como mera aparência no eterno retorno das mesmas situações e estruturas coletivas. Na dimensão mítica, passado, presente e futuro se identificam: as personagens são, por assim dizer, abertas para o passado que é presente que é futuro que é presente que é passado - abertas não só para o passado individual e sim o da humanidade (....). ${ }^{395}$

Por isso, o interesse pelo mito acaba por desnudar mais do que apenas uma volta ao intemporal, à unidade entre sujeito e universo que havia no universo mítico; parece revelarse também uma espécie de "utopia": o anseio de eliminar a individuação burguesa pode ser buscado pelo sujeito, mas nunca superado totalmente, pois o homem, em sua trajetória circular, como descreveu Rosenfeld, sempre cairá no "pecado original, da individuação", o que o leva a querer, posteriormente, distanciar-se dela, aproximando-se do arquetípico nessa caminhada eterna de individualizar-se e, depois, ambicionar a unidade com o outro e com o mundo. Assim, nessa volta ao mito, que é também uma ilusão, a historicidade ainda parece estar presente, a sua maneira, em muitos aspectos, como analisou Rosenfeld a respeito de José e seus irmãos, de Thomas Mann: nessa obra, haveria "um processo supra-histórico: as situações são padrões básicos, incluindo o individualismo burguês (...) e a própria superação desse individualismo extremo. Assim, o romance, além de mito, é ao mesmo tempo utopia" ${ }^{396}$. O mesmo pode se notar em A paixão segundo G.H.: em sua trajetória iniciática, é possível observar, a sua maneira, o aspecto da superação do individualismo da sociedade burguesa - ao ingerir a barata, G.H. extrapola a identificação entre eu e outro -, além de se observar também diversas outras questões marcadamente histórico-sociais, como a luta de classes, a alteridade, a reflexão sobre a arte e a formação do artista. Tudo isso está no cerne do ritual de G.H., para se chegar à origem e ao núcleo de si mesma e do mundo.

Portanto, por meio de sua viagem fantasiosa, G.H. acaba por obliterar a progressão temporal, apagando as distinções entre passado e presente e, assim, esquecendo-se também da sequência histórica dos fatos, ao vê-los todos ali, a sua frente no apartamento, em contínuo. Isso é fruto, justamente, de sua vontade: a união entre eu e o outro, para se chegar ao âmago

\footnotetext{
395 Ibidem, p. 89-90.

396 ROSENFELD, 1994, p. 22.
} 
da vida. Sobre esse aspecto, Oliveira classifica, de acordo com Genette, a forma temporal usada no romance: "a do stasis: o discurso continua, enquanto, no universo ficcional, o tempo parece estacar" ${ }^{397}$ - como se nota, além da viagem da narradora, também na caracterização temporal que ela dá ao momento da experiência com a barata, finalmente vivendo o presente, o eterno agora:

Finalmente, meu amor, sucumbi. E tornou-se um agora.

Era finalmente agora. Era simplesmente agora. Era assim: o país estava em onze horas da manhã. Superficialmente como um quintal que é verde, da mais delicada superficialidade. Verde, verde - verde é um quintal. Entre mim e o verde, a água do ar. A verde água do ar. Vejo tudo através de um copo cheio. Nada se ouve. No resto da casa a sombra está toda inchada. A superficialidade madura. São onze horas da manhã no Brasil. $E$ agora. Trata-se exatamente de agora. Agora é o tempo inchado até os limites. Onze horas não têm profundidade. Onze horas está cheio das onze horas até as bordas do copo verde. $O$ tempo freme como um balão parado. $\mathrm{O}$ ar fertilizado e arfante. Até que num hino nacional a badalada das onze e meia corte as amarras do balão. E de repente nós todos chegaremos ao meio-dia. Que será verde como agora. ${ }^{398}$

A estaticidade do tempo caracteriza, assim, o momento da vivência: o tempo para, e se apresenta como um contínuo entre passado, presente e futuro. Tudo era agora: a préhistória, a barata esmagada, o seu presente (que era o futuro do passado). Oliveira vê, nesse aspecto temporal-espacializado da narrativa de G.H., "o efeito de profundidade, que sugere ao leitor o exame simultâneo da miríade de aspectos, não raro contraditórios, da experiência:

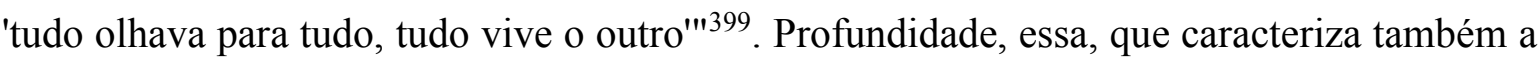
barata e seus olhos, além de definir, justamente, a arte da escultura.

Assemelha-se assim, à maneira de G.H., a sua narrativa com a forma espacial ${ }^{400}$ podendo misturar (e até transformar, de certa forma), então, arte do tempo e arte do espaço. Contudo, não apenas a viagem ocorrida durante a paixão pode caracterizar a narrativa como espacializada, aproximando-se, possivelmente, da escultura, arte de G.H.. Outro elemento

\footnotetext{
397 OLIVEIRA, 1985 , p. 22-23.

398 PSGH, p. 79, grifos meus.

399 OLIVEIRA, 1985, p. 23.

400 Como notou Veronica Stigger na arguição de defesa deste mestrado, o espaço efetivamente dito também é marcado no relato: a narrativa começa com um deslocamento espacial - a narradora que atravessa seu apartamento de luxo, percorrendo o corredor que a leva ao quarto da empregada (depois de tomar seu café da manhã na cozinha, fazendo suas pequenas "esculturas" com os miolos do pão); como bem notado por Stigger, à semelhança das estações da Paixão de Cristo, no qual há os movimentos de caminhada e parada. Inclusive, a expansão temporal que há com a espacialização da narrativa, no momento em que G.H. vê os tempos em contínuo, parece acontecer também com o próprio espaço: ela vê todos os locais da viagem fantasiosa ao mesmo tempo, continuamente. Dessa forma, nota-se, para além da espacialização da narrativa a partir do aspecto temporal, conforme apontado por Joseph Frank, como o próprio espaço aparece com importância no romance.
} 
próprio da forma do relato parece criar, também, uma noção de falta de sequência temporal - conforme notou Alexandre Nodari:

Essa a-temporalidade ou hiper-temporalidade transparece no fato do livro começar e encerrar com seis travessões, indicando circularidade, mas também interrupção, suspensão do curso normal do tempo e do mundo, um intervalo, e ainda algo em andamento (que a frase que segue os travessões inicie com uma minúscula e esteja no gerúndio e se repita - "estou procurando, estou procurando" - reforça este caráter em ato da narrativa e sua temporalidade). ${ }^{401}$

"Suspensão do curso normal do tempo e do mundo": eis o que a paixão oferece à G.H. no momento em que ocorre essa experiência - aspecto, esse, que pode ser evidenciado aos poucos na narrativa: a partir da entrada no quarto e da visão do desenho hieroglífico, préhistórico de Janair; seguido do encontro com o inseto ancestral, a barata; por fim, com a trajetória do imago mundi pós-ingestão da massa branca da sevandija, entrando de fato na experiência da paixão, no agora, tentando alcançar sua própria tragédia, o núcleo de si mesma e de sua vida. De acordo com Nodari, esse aspecto a-temporal ou hiper-temporal-ou, ainda, usando o termo de Frank, intemporal - estaria na própria forma narrativa: o início e o fim da obra com os seis travessões. Semelhantemente à estaticidade do tempo durante a viagem de G.H., os travessões podem, também, dar certa ideia de profundidade - como os olhos da barata, que se reproduziam infinitamente - e de perda de perspectiva na narrativa: uma vez que eles indicam, similarmente, um efeito de eternidade (ou intemporalidade), refletindo-se, no sistema de encaixes narrativos, o próprio relato em si mesmo a partir da repetição desses sinais gráficos, que levam, no final, o leitor à "possibilidade de voltar ao começo do livro, ao tempo das origens ancestrais rememoradas por G.H. e assim re-ler, re-ver, re-conhecer o incognoscível"402.

Paralisa-se o tempo, espacializando-o; assim se espacializa, conforme Frank, a própria narrativa. Junte-se a isso o desenho próprio do relato de G.H., com atributos também visuais: os travessões que iniciam e terminam a narrativa; a repetição interna, que caracteriza o mise en abyme, o encaixe, dando à obra um caráter espiralado, seu próprio "capitel confuso".

Se essa obra, da arte do tempo, apresenta agora tantos atributos próprios da arte do espaço, por que não pensar que, tal qual a barata, a própria narrativa também pode ser considerada como uma escultura verbal? G.H. parece estar buscando a forma inerente do

\footnotetext{
${ }^{401}$ NODARI, Alexandre André. "'A vida oblíqua': o hetairismo ontológico segundo G.H.". O Eixo e a roda, Belo Horizonte, v. 24, n.1, 2015, p. 142.

402 AMARAL, 2005, p. 87.
} 
relato, sua "escultura imanente" - "o conteúdo luta para se formar"403, ou seja, não é a narradora que escolhe propriamente que forma dar a ele: esse é seu grande esforço, próximo do trabalho tátil. É assim, pois, que a narrativa se constrói: "como luta da mão que trabalha contra a resistência da matéria" 404 . O resultado final (por que não?) poderia ser também uma escultura verbal. Ainda, se a barata se torna escultura pela écfrase, que é sua descrição, acrescenta-se, aqui, o fato dessa narrativa ter as características do romance de introversão: ela volta a si mesma e deixa explícita a sua construção formal, descrevendo-se de certa forma. É o que G.H. faz incansavelmente no começo do seu relato, confessando sua dificuldade e, assim, o caminho da sua narrativa - deixando-a nascer livremente, sem moldá-la, mas encontrando sua própria forma imanente ao escrevê-la:

Já que tenho de salvar o dia de amanhã, já que tenho que ter uma forma porque não sinto força de ficar desorganizada, já que fatalmente precisarei enquadrar a monstruosa carne infinita e cortá-la em pedaços assimiláveis pelo tamanho de minha boca e pelo tamanho da visão de meus olhos, já que fatalmente sucumbirei à necessidade de forma que vem de meu pavor de ficar delimitada - então que pelo menos eu tenha a coragem de deixar que essa forma se forme sozinha como uma crosta que por si mesma endurece, a nebulosa de fogo que se esfria em terra. E que eu tenha a grande coragem de resistir à tentação de inventar uma forma.

Esse esforço que farei agora por deixar subir à tona um sentido, qualquer que seja, esse esforço seria facilitado se eu fingisse escrever para alguém. ${ }^{405}$

Ainda, construindo camadas durante a contação do relato, G.H. parece também estar lutando com as mãos para fazer nascer sua obra verbal: moldando, desmoldando e remoldando as palavras, justapondo-as como se justapõe os tempos na sua viagem da paixão; parece que a escultora, agora escritora, funde suas mãos com as palavras, sentindo-as como relevos - como as camadas da barata que podiam de fato ser tocadas -, tal qual Baudelaire, segundo Rodin, escrevia sua poesia. Buscando a forma do relato, busca-se, consequentemente, as palavras ideais para contá-lo; penetrando surdamente no reino das palavras, diria Drummond, G.H. parece buscar (como anunciam as primeiras palavras do livro: "estou procurando, estou procurando"406) e pegar com as mãos aquelas que poderiam traduzir mais fidedignamente sua experiência, unindo-as pouco a pouco, quase esculpindoas, até se obter a forma final. Nota-se como a protagonista, principalmente no começo da narrativa - quando ela parecia ainda atordoada pela experiência e decidindo pela escrita -,

\footnotetext{
${ }^{403}$ LISPECTOR, 1999, p. 254.

${ }^{404}$ PONTIERI, 2001, p. 95.

405 PSGH, p. 13, grifos meus.

${ }^{406}$ PSGH, p. 9.
} 
repete palavras e até parece corrigir-se quando necessário, como se realmente apanhasse o discurso, unindo manualmente os termos necessários, e visualizando se aquela é a forma própria, imanente, de seu conteúdo:

estou procurando, estou procurando. Estou tentando entender. Tentando dar a alguém o que vivi e não sei a quem, mas não quero ficar com o que vivi. Não sei o que fazer do que vivi, tenho medo dessa desorganização profunda. Não confio no que me aconteceu. Aconteceu-me alguma coisa que eu, pelo fato de não a saber como viver, vivi uma outra? A isso quereria chamar desorganização, e teria a segurança de me aventurar, porque saberia depois para onde voltar: para a organização anterior. A isso prefiro chamar desorganização pois não quero me confirmar no que vivi - na confirmação de mim eu perderia o mundo como eu o tinha, e sei que não tenho capacidade para outro. ${ }^{407}$

A repetição de palavras ("estou procurando", "tentando", "vivi", "aconteceu", "chamar") e a antítese entre "organização" e "desorganização", parecendo corrigir-se e justificar sua escolha lexical, podem dar a ideia de que G.H. está, de fato, buscando a melhor forma, as melhores palavras, quase tocando-as para, depois de unidas, visualizar sua forma final. Esse procedimento se aproxima da repetição das frases finais dos capítulos: "retrabalhar fragmentos transformando-os em outras peças, tirando umas de outras"408, que se assemelha, conforme notou Vilma Arêas, "um pouco ao processo de Virgínia ao fazer as figuras de barro" 409 . Parece válido, então, aproximar essas técnicas encontradas em A paixão segundo G.H. com a caracterização que Rodin traça a respeito da escrita tátil de Baudelaire: seria como se reproduzisse, dessa forma, a carga de um impacto de pensamento, de sua experiência arrebatadora: buscando o núcleo do mundo, onde a vida era maior, mais selvagem e sem calma - e, também, buscando a "escultura imanente" dessa experiência, para transformá-la em arte.

Curiosamente, essa característica essencial da atemporalidade que traria, assim, o aspecto visual à arte temporal também parece própria de uma forma de esculpir, denominada talhe direto. Essa maneira específica de se fazer escultura pode captar muitos aspectos trabalhados, até aqui, sobre a escrita de G.H.: vive-se, durante a criação artística, um "tempo sem tempo"; em consequência, uma "ausência da realidade", ao passo que, paradoxalmente,

\footnotetext{
${ }^{407}$ PSGH, p. 9.

408 ARÊAS, Vilma. "A hora da estrela". In: Clarice Lispector com a ponta dos dedos. São Paulo: Companhia das Letras, 2005, p. 84.

${ }^{409}$ Ibidem.
} 
confrontando-se diretamente com ela ${ }^{410}$; por fim, essa própria matéria, nascida do "conhecimento de uma verdade", dá origem à arte por meio de um trabalho com "envolvimento físico" - como o tato, conforme aproxima Pontieri revisitando Bachelard, caracteriza a "materialização o imaginário" que é a essência de A paixão segundo G.H.: tentar transpor, em palavras, o ocorrido. Pode-se pensar, finalmente, que essa matéria (agora arte, o resultado de um processo criativo) acaba por pertencer ao artista, tal qual os travessões de G.H. e sua forma de encaixe parecem relatar a perene natureza da sua experiência, que nunca deverá ser esquecida por ela, e que faz dessa travessia física e mentalmente tortuosa "uma alegria difícil; mas chama-se alegria"411:

Trabalhar em talhe directo sobre um bloco, remete para um tempo sem tempo, (...) para uma relação que equaciona harmonicamente o ser e o fazer dando sentido e significado à phisys grega num envolvimento fisico que sintetiza o significado da Escultura. Físico no sentido de uma integridade do Corpo, da plenitude do todo, absorvido numa actividade, como se o 'à volta' não existisse. Um estado de ausência da realidade que nos envolve, um confronto com a realidade ela mesma, do Corpo com a Matéria. Mas está para além de um confronto, de uma relação, é como se a matéria que se conforma passasse a pertencer ela mesma à nossa totalidade. Como se pelo facto de a talharmos nos talhássemos a nós próprios numa unidade dinâmica entre corpo, espírito e matéria. É a forma de conhecimento de uma verdade que não se entende de outra maneira. Um processo que tem de ser experienciado para ser percebido. Um inebriante esforço físico e mental que ao final do dia ainda faz a Maria [Lino] dizer: "Hoje foi bom..."412

\subsection{3 "Se fosse eu, trabalharia só com as mãos": entre G.H. e Clarice}

Esculpindo se estaria tocando na própria coisa - como refletiu Clarice ("Certas páginas, vazias de acontecimentos, me dão a sensação de estar tocando na própria coisa, e é a maior sinceridade. É como se eu esculpisse" ${ }^{413}$ ) e seus entrevistados escultores, como Bruno Giorgi, já demonstrado. E a escultora G.H., cuja arte serviu de um pré-clímax para sua experiência desconcertante, toca na própria coisa quando ingere do impuro da barata - e tenta repetir a experiência desse contato íntimo com o neutro ao transpor sua memória do dia anterior em uma escrita que se aproxima, a sua maneira, da arte espacial e da escultura.

\footnotetext{
${ }^{410}$ A realidade à sua volta é paralisada durante a experiência - vide, por exemplo, a viagem atemporal e extraespacial da narradora -, justamente no momento da paixão, em que G.H. a confronta, tentando alcançá-la, descobri-la, empenhando-se para tocar o seu núcleo.

411 PSGH, p. 5 (Dedicatória de Clarice Lispector, "A possíveis leitores").

${ }^{412}$ SILVA, João Castro. "Maria Lino: a escultura como modo de vida". Revista Estúdio, vol. 9, n. 23, Lisboa, set./2018, p. 130-132, grifos meus.

${ }^{413}$ LISPECTOR, 2018, p. 657, grifos meus.
} 
Tal sinceridade na qual se chegaria ao tocar - atributo próprio do fazer escultórico a própria coisa, é o mundo visto "totalmente e na sua verdadeira realidade"414. Como já analisado anteriormente, para Clarice, o artista "perfeito" seria aquele que, livrando os seus sentidos do utilitarismo, conseguiria chegar nesse núcleo da realidade, tornando-se inocente. A "estética da inocência"415, portanto, apresenta-se também na paixão de G.H.: buscando a "coisa", o neutro. Por meio da ingestão da massa branca da barata, busca-se a purificação da mulher que deseja tornar-se inocente a partir de um ato pecaminoso. Por isso que alcançar a inocência é impossível: G.H. já presenciou o mal do mundo. O paradoxo se esclarece: "a inocência almejada é conscientemente inocente, trata-se, pois, de uma construção estética nada inocente da inocência"416.

Sabe-se que é difícil resumir as obras de Clarice Lispector. A paixão segundo G.H. é uma dessas leituras que não se pode simplesmente contar seu enredo sem que uma enorme parte da narrativa seja perdida. Não se trata apenas de uma escultora, em seu apartamento e sua vida luxuosos, arrumando a casa após demitir sua empregada, encontrando um desenho deixado por ela e, depois, uma barata no seu guarda-roupa, da qual ela ingere. Mas a máxima "tocar na própria coisa" pode, de certa maneira, condensar a ideia principal dessa narrativa (e de outras clariceanas): a trajetória da paixão se dá no toque, no contato íntimo com o outro que é sinônimo de impureza, de pecado e de asco. É apenas dessa forma que G.H. pode descobrir a si mesma e ao funcionamento da sociedade, desumanizando-se ao provar da massa branca do animal, deixando de lado sua "terceira perna" que a organizava em sua vida pré-experiência com a barata.

Uma narrativa aparentemente abstrata, mas que, se olharmos atentamente, é apenas "o figurativo de uma realidade mais delicada e mais difícil, menos visível a olho nu"417. Realidade, essa, que a lupa clariceana nos permite enxergar, transgredindo nossa miopia: além da crueldade das classes mais altas que não enxergam o outro das classes mais baixas e do egoísmo de uma vida luxuosa, representados por G.H. em sua relação com Janair, há a nossa própria dificuldade, como seres pertencentes a uma sociedade pré-organizada, do autoconhecimento mais profundo e verdadeiro, o que leva a personagem à necessidade da despersonalização, alcançada pela paixão, pela comunhão com o demoníaco, a barata:

\footnotetext{
${ }^{414}$ LISPECTOR, 1999, p. 228.

${ }^{415}$ C.f.: RUFINONI, op. cit.

${ }^{416}$ Ibidem, p. 360.

${ }^{417}$ LISPECTOR, 1999, p. 316.
} 
o movimento regressivo em direção ao inumano, ao inanimado, como se fosse preciso sucumbir ao plasma (ou planctum, como denomina G.H.) que dá corpo à vida para enfim despertar-se. O processo é todo negativizado: des-apego, des-montagem, desconstrução. A entrada nessa experiência de desfiguração pressupõe abandono da forma humana. (...)

O pathos de nossa personagem está justamente na desconfiguração do sujeito para reunificá-lo às forças míticas da natureza. G.H., nesse sentido, ingere a flor de lótus/barata para reencontrar-se com a unidade essencial dos seres naturais, fusão orgânica do homem com o mundo primário. É preciso perder a memória, suporte da subjetividade, para adentrar o universo pastoso da totalidade, da "neutralidade viva lutando". ${ }^{418}$

Graças ao abandono da vida anteriormente pomposa e acomodada, e da busca por conhecer a si mesma e ao mundo primevo dos seres humanos, G.H. parece passar também por uma trajetória de formação do artista. Ao passo que, tocando no de-dentro da barata, a mulher G.H. deixa sua "terceira perna" para trás, a artista G.H. parece também deixar suas crenças e conformismos de lado para poder se tornar, quiçá, uma artista (im)perfeita.

\subsection{Uma artista (im)perfeita?}

A vida me fez de vez em quando pertencer, como se fosse para me dar a medida do que eu perco não pertencendo. E então eu soube: pertencer é viver. Experimentei-o com a sede de quem está no deserto e bebe sôfrego os últimos goles de água de um cantil. E depois a sede volta e é no deserto mesmo que caminho. ${ }^{419}$

Estou sentindo uma clareza tão grande que me anula como pessoa atual e comum: é uma lucidez vazia, como explicar? assim como um cálculo matemático perfeito do qual, no entanto, não se precise. Estou por assim dizer vendo claramente o vazio. E nem entendo aquilo que entendo: pois estou infinitamente maior que eu mesma, e não me alcanço. Além do quê: que faço dessa lucidez? Sei também que esta minha lucidez pode-se tornar o inferno humano - já me aconteceu antes. Pois sei que - em termos de nossa diária e permanente acomodação resignada à irrealidade - essa clareza de realidade é um risco. Apagai, pois, minha flama, Deus, porque ela não me serve para viver os dias. Ajudai-me a de novo consistir dos modos possíveis. Eu consisto, eu consisto, amém. ${ }^{420}$

Pertencer e consistir podem resumir um dos maiores desejos clariceanos, transportado para suas obras. G.H. em sua vida pré-narrativa também consistia e pertencia fidedignamente à sociedade. No entanto, como para a narradora de "A lucidez perigosa", uma certa lucidez perigosa toma conta da protagonista após a experiência com a barata, permitindo-lhe tornar o inferno humano com sua clareza de realidade. A impossibilidade de

\footnotetext{
418 ROSENBAUM, 2006, p. 160-161.

419 LISPECTOR, Clarice. "Pertencer". In: A descoberta do mundo. Rio de Janeiro, 1999, p. 112.

420 LISPECTOR, Clarice. "A lucidez perigosa". In: A descoberta do mundo. Rio de Janeiro: Rocco, 1999, p. 403.
} 
retornar à vida "normal" após essa experiência é incontestável, tanto para G.H. quanto para a narradora do conto acima. Um certo apagamento da chama da vida, uma amnésia do que se passou, seria necessário para que o pertencimento social fosse novamente alcançado.

Contudo, a artista G.H., agora não só escultora como também escritora, pode usufruir dessa experiência desconcertante para, justamente, tornar-se uma artista perfeita nos moldes clariceanos, como demonstrado com sua crônica nas seções anteriores; ou uma artista efetivamente dita segundo tantos críticos que se debruçaram sobre o assunto - como se vê na segunda parte deste texto, acerca das reflexões sobre o artista moderno. Antes conformada em sua posição social, agora G.H. em sua desumanização e em sua dissociação do corpo coletivo poderá, enfim, transgredir as normas da sociedade e poder, assim, transgredir também como artista: libertando-se de tudo que a prendia e a definia - uma escultora amadora, mulher de classe média/alta cujo apartamento na cobertura refletia o domínio da burguesia -, desumanizando-se, G.H. parece entrar, enfim, para a categoria dos artistas tais quais discriminados por Marcuse: sujeitos cuja vida discordante das regras civilizatórias os mantêm à margem.

Retomando a crônica clariceana "O artista perfeito", a libertação, a purificação e a inocência seriam essenciais para a formação do artista. G.H. liberta-se e purifica-se de seu lugar estabelecido no corpo social, a partir do pathos demoníaco, inocentando-se da condição humana. Dessa forma, ela se torna agora uma estranha, uma incongruente - utilizando os termos de Herbert Marcuse. A narrativa, ao passo que rememora sua experiência e a torna uma nova artista também escritora, faz com que a protagonista seja cada vez mais posicionada à margem da sociedade, constituindo uma espécie de outsider clariceano:

(...) o Outsider é um homem que não pode viver no mundo confortável e isolado da burguesia, aceitando o que ele vê e toca como realidade. "Ele vê muito e profundamente", e o que ele vê é essencialmente o caos. (...)

O Outsider (...) tem uma aflitiva sensação de que a verdade deve ser dita à qualquer custo, do contrário não pode haver qualquer esperança para uma restauração derradeira da ordem. Mesmo se não parece haver lugar para a esperança, a verdade deve ser dita. ${ }^{421}$

${ }^{421}$ WILSON, Colin. The Outsider. Nova Iorque: Diversion Books, 2014, e-book. Tradução livre do trecho:

(...) the Outsider is a man who cannot live in the comfortable, insulated world of the bourgeois, accepting what he sees and touches as reality. "He sees too deep and too much", and what he sees is essentially chaos. (...)

The Outsider (...) has a distressing sense that truth must be told at all costs, otherwise there can be no hope for an ultimate restoration of order. Even if there seems no room for hope, truth must be told. 
A verdade que G.H. entrevê por meio da barata deve ser dita. O caos da experiência humana em sociedade é o motivo que a faz desejar a despersonalização, mesmo não havendo perspectiva de mudar essa realidade. Parece que G.H. é, assim, a detentora do conhecimento verdadeiro sobre a humanidade, descoberta como doente e imperfeita, e ela deve contá-lo a alguém. É a partir daí que ela se torna uma escritora, inventando a mão decepada justamente para simbolizar o seu leitor imaginário. A arte da escrita é necessária para, além de salvá-la de sua vivência, comunicar essa veracidade que, aparentemente, só ela vê a respeito da sociedade.

Parece ser possível concluir, então, que a narrativa da experiência de G.H. é sua própria trajetória de formação artística, como alguém que forja a liberdade diante das amarras sociais que nos prendem e definem; como alguém que, como definiu Herbert Marcuse a respeito do sujeito artista ${ }^{422}$, é inconciliável com a sociedade, vivendo à margem dela, negando-a. E essa trajetória é conquistada graças à G.H. tornar-se, com a narrativa, uma escritora, o que lhe permite compartilhar sua visão sobre a civilização, a suposta verdade sobre ela, a um leitor implícito (da sua mão decepada) e real (nós, leitores concretos clariceanos).

Apesar do leitor não saber os caminhos artísticos e pessoais de G.H. após a experiência e a conclusão da narrativa, pode-se analisar que esses travessões que tanto abrem quanto fecham a obra significam uma experiência inesquecível para a narradora - a lógica do "eterno retorno": tal qual o homem sempre volta ao mito, segundo Rosenfeld, G.H. parece, assim, indicar o constante regresso para a sua própria paixão -: parece que tudo o que está constituído dentro desses sinais gráficos são uma constante lembrança para a personagem, que sempre se encontrará com sua experiência narrada dentro desses doze travessões, para que ela não volte a ser a mesma G.H. que, antes, tinha sua "terceira perna" a qual a impedia de se autoconhecer e conhecer o mundo à sua volta ${ }^{423}$.

Portanto, a narrativa que tanto carrega (como demonstrado com a barata) e tanto pode se assemelhar à escultura, arte original de G.H. - uma vez que, além da espacialização do tempo na viagem pré-histórica, seu movimento espiralado das camadas narrativas parece imitar, como já visto, o moldar e desmoldar (ou o talhar) do escultor, que tantas vezes desmonta e remonta sua escultura até sua versão final, a qual terá em sua forma, de alguma

\footnotetext{
422 MARCUSE, Herbert. Op. cit..

${ }^{423}$ Como reflete a narradora, ela de fato não seria a mesma após a experiência: "Essa ela, G.H. no couro das valises, era eu; sou eu - ainda? Não.". PSGH, p. 31; "Eu sabia que estava me despedindo para sempre de alguma coisa, alguma coisa ia morrer". PSGH, p. 73, grifos meus.
} 
maneira (mesmo não transparecendo) todos os movimentos de ir além e voltar atrás nos toques do objeto - é condição necessária de G.H. para salvar a si mesma e aos outros pela arte da palavra, contando sua experiência de autêntica inexpressividade para quem se motive a lê-la. A maldição necessária da escrita passa de Clarice para G.H., de criador para criatura, demonstrando no exemplo literário da fícção como a escrita é essa espécie de dor imprescindível para remissão da condição humana. Como Cristo na cruz, que passa pela experiência da paixão, atravessa sua angústia completamente humana para salvar o outro, divinizando-se assim, G.H. passa pela ingestão do outro impuro para também salvar a si e aos outros, pela escrita de sua experiência, atravessando sua angústia de perder sua organização primária como indivíduo na sociedade ${ }^{424}$. Como uma via-crúcis, G.H. se torna artista finalmente genuína e "des-domesticada".

Eis A paixão segundo G.H.: a escrita como instrumento de salvação não apenas de si própria, mas do outro. Se Cristo, para Clarice, era "bobo" porque se "tivesse sido esperto não teria morrido na cruz" 425 , a experiência que G.H. vive a torna, por um tempo, "boba" (tocando por instantes a inocência do neutro, cujo símbolo é a barata), ao passo que, em um ato de amor aprendido com sua experiência ${ }^{426}$ - "É quase impossível evitar excesso de amor que o bobo provoca. É que só o bobo é capaz de excesso de amor. E só o amor faz o bobo." ${ }^{427}-$, transmite sua própria travessia da paixão para esse outro desconhecido que é seu leitor, redimindo-o a partir de seu próprio pathos, seja ele quem for. O bobo aproxima-se da reflexão sobre o artista perfeito, do qual fala Clarice: aquele que está distante dos significados utilitários que nos são dados sobre o mundo, enxergando, assim, o núcleo sincero da realidade, tentando realcançar a inocência perdida.

\footnotetext{
${ }^{424}$ Como a paixão de Cristo, que redime os homens, a paixão de G.H. transportada pela escrita também deveria ensinar àqueles que a leem, para que eles não passem pela mesma experiência que ela - atravessando, assim, pela sua "orgia infernal", o próprio "martírio humano" (PSGH, p. 131) -:

Se tu puderes saber através de mim, sem antes precisar ser torturado, sem antes teres que ser bipartido pela porta de um guarda-roupa, sem antes ter quebrado os teus invólucros de medo que com o tempo foram secando em invólucros de pedra, assim como os meus tiveram que ser quebrados sob a força de uma tenaz até que eu chegasse ao tenro neutro de mim - se tu puderes saber através de mim... então aprende de mim, que tive que ficar toda exposta e perder todas as minhas malas com suas iniciais gravadas. (PSGH, p. 115)

425 LISPECTOR, Clarice. "Das vantagens de ser bobo". In: A descoberta do mundo. Rio de Janeiro: Rocco, p. 310-311.

426 "Terá sido o amor o que vi? Mas que amor é esse tão cego como o de uma célula-ovo? foi isso? aquele horror, isso era amor? amor tão neutro (...)". PSGH, p. 18.

427 PSGH, p. 18.
} 


\subsection{Uma aprendizagem artística}

Pretendeu-se demonstrar, aqui, uma leitura de A paixão segundo G.H. evidenciando como a escultura, arte original da narradora, perpassa também sua literatura; como a arte parece ser um dos temas dessa narrativa clariceana; e como a trajetória de G.H. pode contribuir para a formação artística da narradora - formação, essa, que parece ir além da questão do artista ao se desvencilhar das amarras sociais, vivendo, assim, de forma conflituosa com o mundo a sua volta, conforme descreveu Herbert Marcuse a respeito do Künstlerroman. Além desse tipo de formação, outra parece se apresentar: a de conhecimento da história da arte e de seus diversos movimentos ${ }^{428}$.

Por meio da barata e do desenho de Janair, foi possível observar como a questão da arte perspectívica e aperspectívica pode se fazer presente no relato - e como, também, a arte moderna e não-moderna parece ali se misturar: a barata, transformada em escultura verbal e, portanto, tridimensional, é perspectívica, ou seja, remonta à arte não-moderna, mas também se assemelha à arte moderna por se aproximar dos ready mades; já a pintura da ex-empregada é similar às pinturas rupestres, arte arcaica, pré-histórica, e também aperspectívica, à moda das vanguardas. G.H., como narradora do relato (e detentora do conhecimento que ali ela experienciara, de se deparar com o desenho de Janair na parede e de ver e provar a barata, transformando-a em arte), comunica sua visão ao leitor, com o intuito de, com ele, compartilhar sua vivência.

Contudo, há uma instância que paira acima da autoridade da voz da protagonista, a qual elabora a composição romanesca de A paixão segundo G.H. e, portanto, é responsável também por elaborar essas obras perspectívicas e aperspectívicas, modernas ou arcaicas - a essa instância pode-se, talvez, aproximar o conceito de "autor implícito", definido por Wayne Booth $^{429}$. Essa "autoridade" maior é a verdadeira criadora do jogo entre os diferentes modos de ver e representar a arte (o perspectivismo, o aperspectivismo, a arte moderna e não moderna), formalizando-as e, de certa maneira, discutindo-as.

Ao inserir, então, todos esses tópicos artísticos que levam o leitor a pensar as diferentes manifestações da arte através dos tempos, propõe-se uma reflexão: tal formação do artista não é experienciada apenas por G.H. no seu ritual, que começa com a ida ao quarto

\footnotetext{
428 Interessante perceber (como o fez Veronica Stigger, a quem devo essa observação) que a epígrafe de $A$ paixão segundo G.H. é de Bernard Berenson, um historiador da arte. É possível notar, então, como a reflexão sobre arte pode estar inserida, a sua maneira, desde antes da narrativa de fato se iniciar.

429 BOOTH, Wayne. The rethoric of fiction. Chicago: The University of Chicago Press, 1983.
} 
da empregada e com a visão de seu desenho, mas pode também ir além dessa instância narrativa, fazendo parte da arquitetura geral da obra. Em outras palavras, pode-se interpretar que a própria composição do romance, sua construção estética, parece propor questões que despertam um exercício complexo de aprendizado, diálogo e impasses da arte moderna em face da questão social, que a formalização da obra parece trazer consigo.

Importante relembrar, ainda, Solange Ribeiro de Oliveira, que, além de ter demonstrado um arcabouço de referências da história da arte que a narrativa parece carregar, considera a escultura de G.H. como uma metáfora para a destruição do sistema civilizatório ocidental. Essa seria a busca pela "escultura imanente", corroendo a "matéria" (as estruturas ideológicas) para encontrar sua forma natural, chegando-se à desumanização. Pode-se pensar, semelhantemente a essa ideia, que o próprio percurso artístico do homem ocidental, desde a pré-história até a modernidade - demonstrada, dessa forma, tanto na narrativa, por G.H., quanto pelo autor implícito -, parece ser também outro significado para a metáfora da procura da "escultura imanente": desgastar a "matéria", que, agora, é a trajetória histórica da arte do Ocidente - procurando destruir as "camadas arqueológicas" que a cobrem, é possível chegar, visualizando boa parte do percurso artístico humano e suas diferentes maneiras de expressão, ao mural de Janair: a arte primeva do homem das cavernas.

Logo, o movimento do próprio romance, ao inserir todo esse desdobramento sobre a arte e suas formas de representação, parece seguir a definição de G.H. sobre a procura da "escultura imanente": "auscultando os objetos, algo desses objetos virá que me será dado e por sua vez dado de volta aos objetos" ${ }^{430}$. Dessa maneira, pode-se pensar como a dimensão estética que nasce da estruturação do romance $A$ paixão segundo G.H., ao investigar os movimentos da arte e suas diferentes expressões - inserindo-os na narrativa a partir do desenho de Janair e da barata que se faz escultura -, parece fazer com que tanto a própria narradora quanto a composição final da obra carreguem consigo a experiência de formação artística. Triunfo da construção clariceana, que pode ter conseguido, assim, tratar um de seus temas mais recorrentes, a arte, em diversas esferas dentro de um mesmo romance.

${ }^{430}$ PSGH, p. 26. 


\section{CONTEMPLANDO AS ESCULTURAS DE G.H.: À GUISA DE CONCLUSÃO}

Imaginemo-nos em uma espécie de "museu verbal", em uma exposição das obras de G.H., na qual se pudesse contemplar suas diversas "esculturas verbais", dispostas no relato do fatídico dia em que ela decidira arrumar o quarto da empregada. Percorrendo a leitura de A paixão segundo G.H., com a proposta aqui feita de estudar a influência e o papel da escultura nesse romance, talvez seja possível, de alguma forma, visualizar essa exposição e classificar as suas variadas esculturas "moldadas" no decorrer da contação da vivência.

Primeiramente, é importante considerar o fato de que G.H. se apresenta ao seu leitor já como uma escultora, de modo que seja importante levar em conta que a artista já produzia anteriormente à paixão - e essas esculturas não seriam, como a barata, "verbais". Essas obras, desconhecidas ao leitor, não aparecem na narrativa, mas pode-se inferir que elas existem, devido, justamente, à autocaracterização da personagem como escultora - "Ter feito escultura durante um tempo indeterminado e intermitente também me dava um passado e um presente que fazia com que os outros me situassem: a mim se referem como a alguém que faz esculturas que não seriam más se tivesse havido menos amadorismo" 431 . Além disso, caso se julgue que a protagonista continuará fazendo esculturas após sua paixão, é válido pensar que essas novas obras pós-experiência serão diferentes das anteriores, uma vez que, como proposta de leitura nessa dissertação, G.H. poderá ser uma nova artista que passou por uma travessia de afastamento da sociedade ao conhecer o mundo pré-humano - por isso, a aproximação possível desse romance com o Künslterroman, o qual teria, como base, a formação do artista de modo que este, agora, levaria uma vida deslocada das normas civilizatórias -; dessa forma, sua arte também poderá sofrer mudanças significativas. Assim, haveria duas subcategorias dessas esculturas efetivamente ditas da personagem: antes e depois da paixão.

Finalmente investigando as esculturas presentes, de fato, no relato de G.H., a primeira que chamaria atenção seria a mão do leitor: essa mão decepada - comparada, inclusive, com a escultura La Cathédrale, de Rodin - seria constituída, como se pretendeu defender, uma experiência escultórica na escrita, podendo ser lida como uma escultura idealizada na imaginação da personagem. A protagonista demonstra certa necessidade de imaginar

\footnotetext{
${ }^{431}$ PSGH, p. 25.
} 
seu(sua) companheiro(a) que a acompanharia durante o relato de sua trajetória. Como ela está impossibilitada de talhar imageticamente essa pessoa por inteiro ("Não estou à altura de imaginar uma pessoa inteira porque não sou uma pessoa inteira." ${ }^{432}$ ), a mão é a parte imaginada e "moldada" por ela - órgão, esse, fundamental para acalentá-la ("Enquanto escrever e falar vou ter que fingir que alguém está segurando a minha mão"433), além de ser a ferramenta primordial e essencial do escultor.

Páginas à frente, o leitor se depara com a segunda escultura: a barata - não sem antes, claro, vislumbrar o mural de Janair, outra marca das artes visuais na obra. O inseto é um dos elementos fundamentais da narrativa e é a partir dele que esta dissertação apresentou e constituiu a ideia de "escultura verbal". No relato de G.H., como defendido, a écfrase - tida como artifício retórico que une arte do tempo e arte do espaço - é usada para descrever a barata ao leitor, com o objetivo da protagonista de transmitir sua própria experiência da maneira mais fiel possível a quem a lê. A tridimensionalidade, a espacialidade e os movimentos vistos na sevandija (seus cílios, sua massa branca, entre outros já tão mencionados) podem aproximá-la, de certa forma, dessa arte escultórica, cujo atributo diferencial é, justamente, ocupar um espaço efetivo na realidade - em oposição à pintura e, também, ao desenho, como discutido. Assim, nota-se como a experiência escultórica da narradora pode fazê-la atingir seu objetivo de comunicar a outros o que se passara no quarto, apresentando na arte literária, vívida e mimeticamente, o inseto que a espanta.

A terceira obra visual que se pode pensar, aqui, é a de Janair: se é possível defender a écfrase da barata como uma escultura verbal, por que não se poderia afirmar o mesmo sobre o retrato de Janair? Ao rememorar sua fisionomia, G.H. também a descreve ao leitor, com uma diferença fundamental: a antiga empregada era rasa, "o corpo ereto, delgado, duro, liso, quase sem carne, ausência de seios e de ancas", opondo-se, como já mostrado, ao inseto. Seu aspecto aplainado, como mostrado na análise, remete à pintura, em contraposição com a tridimensionalidade da barata. Dessa forma, se não puder ser uma escultura verbal, por que não poderia ser, ao menos, uma pintura verbal? Ainda, G.H. também rememora seu rosto "Revi o rosto preto e quieto, revi a pele inteiramente opaca que mais parecia um de seus modos de se calar, as sobrancelhas extremamente bem desenhadas, revi os traços finos e delicados que mal eram divisados no negror apagado da pele" -, sendo esse também destacado na escultura do inseto. No entanto, outra diferença pode ser mencionada, no que

\footnotetext{
432 PSGH, p. 16-17.

433 PSGH, p. 16.
} 
concerne às razões de evocar a imagem de Janair: enquanto a barata é mostrada ao leitor para ele vivenciar o mesmo que G.H., parece que a descrição ecfrástica de Janair serve de alívio a uma espécie de culpa, não só por anteriormente ter se esquecido de como era a antiga empregada, mas também pela questão ideológica que move o enredo: a luta de classes, o ódio contra o outro de classe mais baixa. Pode-se interpretar, então, que G.H. traça essa caracterização de Janair como um possível pedido de desculpas nas entrelinhas, notando seus "traços de rainha" e, inclusive, parecendo desejar se absolver da culpa de sua invisibilidade ao descrever suas roupas usadas - "Não era de surpreender que eu a tivesse usado como se ela não tivesse presença: sob o pequeno avental, vestia-se sempre de marrom escuro ou de preto, o que a tornava toda escura e invisível" 434 .

A quarta escultura que se pode considerar é a própria narrativa. Ao contar sua experiência pela escrita, G.H. parece também inserir na forma narrativa o elemento visual. Seja na configuração da repetição das frases em cada início de capítulo, que dá à forma da Paixão um caráter visual, imagético e espiralado - inclui-se, nos anexos, o "desenho" exposto na obra de Olga de $\mathrm{Sá}^{435}$, para facilitar na visualização desse aspecto -; seja nas recusas que a fazem, de início, hesitar em contar o que se passara, fazendo-a avançar na obra sem propriamente avançar em relatar a experiência ("forma feita de formas opostas"436, como um ouroboros, um avanço na narrativa que, paradoxalmente, não é propriamente um avanço narrativo); seja, ainda, na própria descrição que o romance parece fazer de si mesmo, antes de G.H. contar propriamente a experiência - podendo ser classificado, portanto, como um tipo de romance de introversão. G.H. parece, assim, escrever e "desescrever", narrar e "desnarrar", hesitar para avançar e, avançando, ela hesita novamente. Trabalhando com a palavra, a (agora) escritora parece escrever como um escultor, que talha, corrige, forma e desforma o material bruto até obter a escultura pretendida, imanente ao objeto. E a presença do mito na narrativa - o da busca da origem -, reforçada pela viagem ilusória pós-ingestão da barata, parece reforçar, a exemplo dos textos de Joseph Frank e de Anatol Rosenfeld, como a narrativa moderna (e esse exemplo clariceano) é muito mais espacial do que temporal. Tempo e espaço praticamente se confundem; o tempo é espacializado: um contínuo de passado, presente e futuro, que o escritor/narrador se apropria para criar sua narrativa. Essa "escultura da narrativa" pode se aproximar da ideia de leitura ideológica de A paixão segundo G.H.: retomando novamente Solange Ribeiro de Oliveira, "O trabalho de G.H. consiste

\footnotetext{
434 PSGH, p. 40.

435 SÁ, 2004, p. 155.

436 C.f.: AMARAL, op. cit.
} 
precisamente em desconstruir o arcabouço ideológico onde se encaixa a experiência da história ocidental. Nisso consiste o que ela chama de 'desgastar pacientemente a matéria', para encontrar 'a escultura imanente'"'437 - pode-se, inclusive, considerar essa desconstrução ideológica que Oliveira vê em G.H. como uma quinta escultura, já que, para ela, a atividade escultórica seria apenas uma metáfora para a despersonalização da protagonista, seu afastamento da ideologia predominante que a prendia. Assim, a escultura de G.H. na obra, nascida da sua experiência com o outro e com o pré-histórico, teria justamente essa finalidade: de narrar sua desmontagem do sistema civilizatório para se alcançar a desumanização, no ritual que ela denomina paixão. Ainda, parece haver, também, uma "desmontagem" da história da arte no romance, dando à G.H. uma outra experiência de educação artística, para além de seu possível desprendimento social, tornando-a, enfim, uma artista nos moldes do Künstlerroman.

Dessa forma, pretendeu-se demonstrar como G.H., ao tocar profundamente no neutro, parece aproveitar a arte do tato - sua arte primeva - na arte verbal, sua arte necessária pósexperiência. Mesmo não sendo esculturas propriamente ditas, concretas, presentes no mundo real, as esculturas verbais e imaginárias de G.H. têm papel importante no relato que a narradora (escultora e, agora, escritora) tanto se esforça para traçar. Como já apontado, a arte é um tema importante na obra clariceana e, com a escultura, ela ganha um patamar inédito, já que em outros livros o trabalho se dá em volta, principalmente, da escrita (como $A$ hora da estrela) ou da pintura (como Água viva). Clarice Lispector consegue, assim, em A paixão segundo G.H., de certa maneira alcançar um de seus grandes desejos, transportados para sua protagonista: "Se fosse eu, preferia trabalhar sempre com as mãos." ${ }^{438}$

\footnotetext{
${ }^{437}$ OLIVEIRA, 1993, p. 120.

${ }^{438}$ LISPECTOR, 2007, p. 207.
} 


\section{ANEXOS}

1. Auguste Rodin, La Cathédrale (1908)

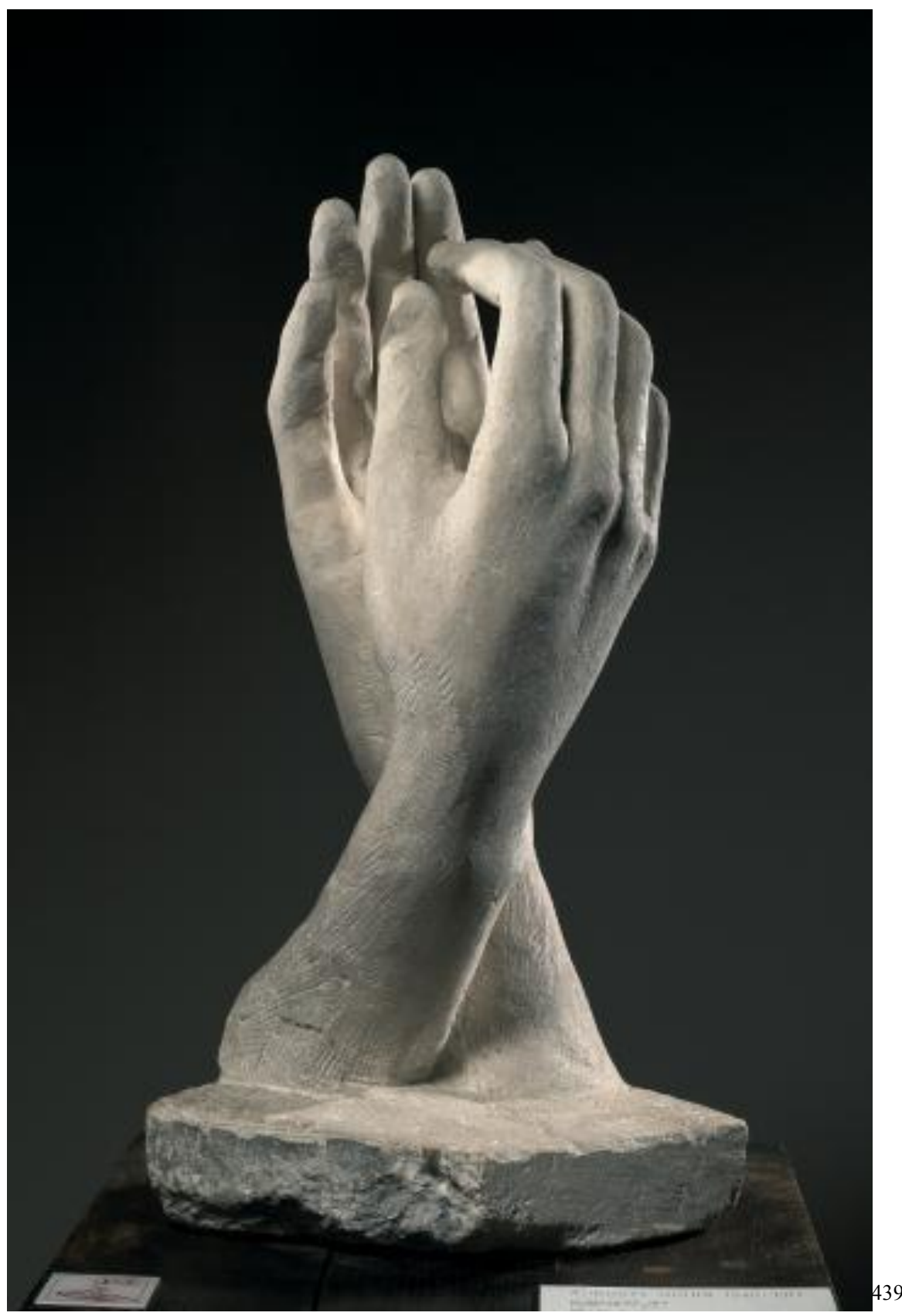

439 Disponível em: http://www.musee-rodin.fr/es/colecciones/esculturas/la-catedral. 
2. Constantin Brancusi, O beijo (1910)

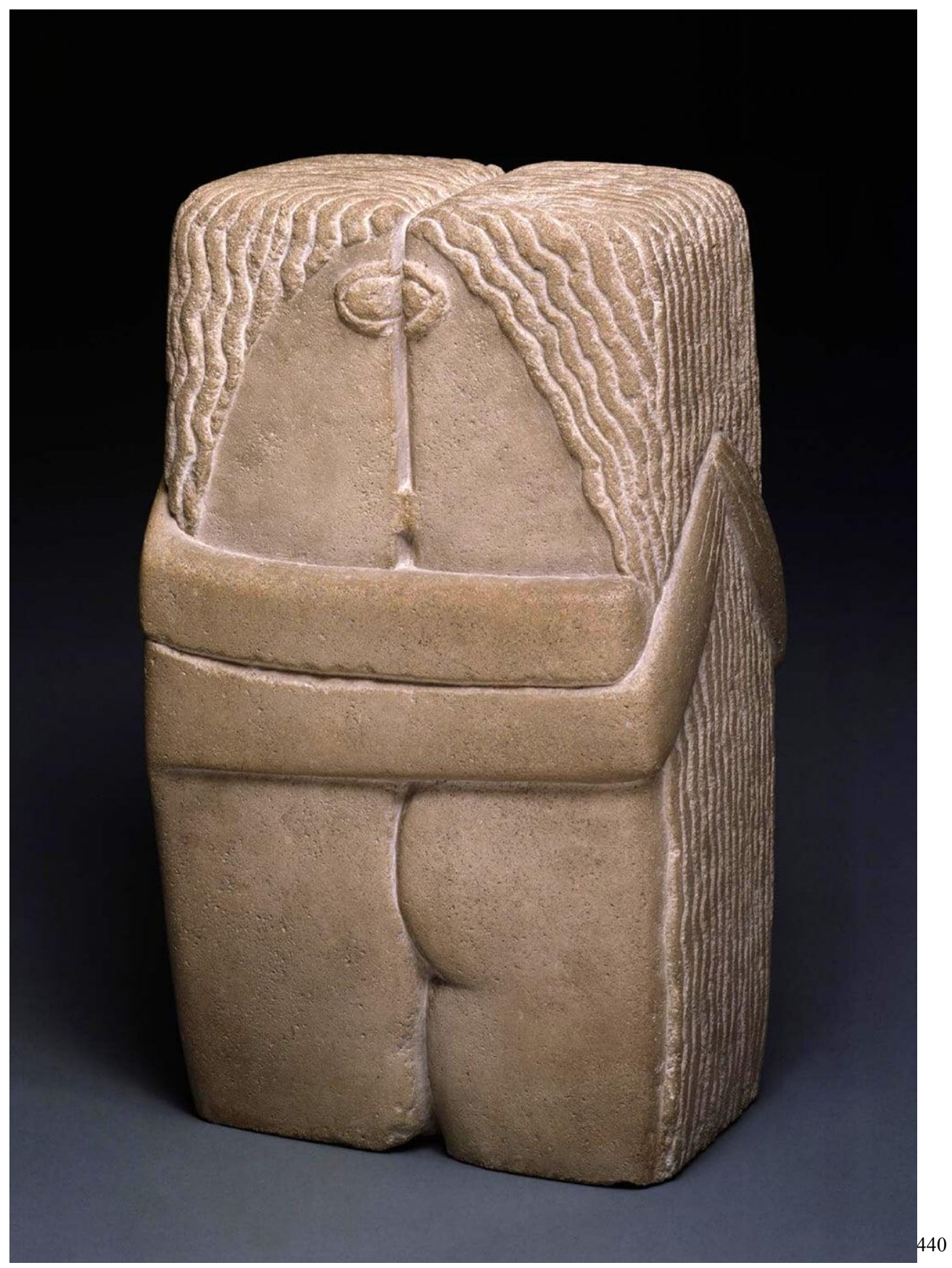

440 Disponível em: https://www.revistabula.com/9966-os-10-beijos-mais-famosos-da-historia-da-arte/ 
3. Constantin Brancusi, O recém-nascido (1925)

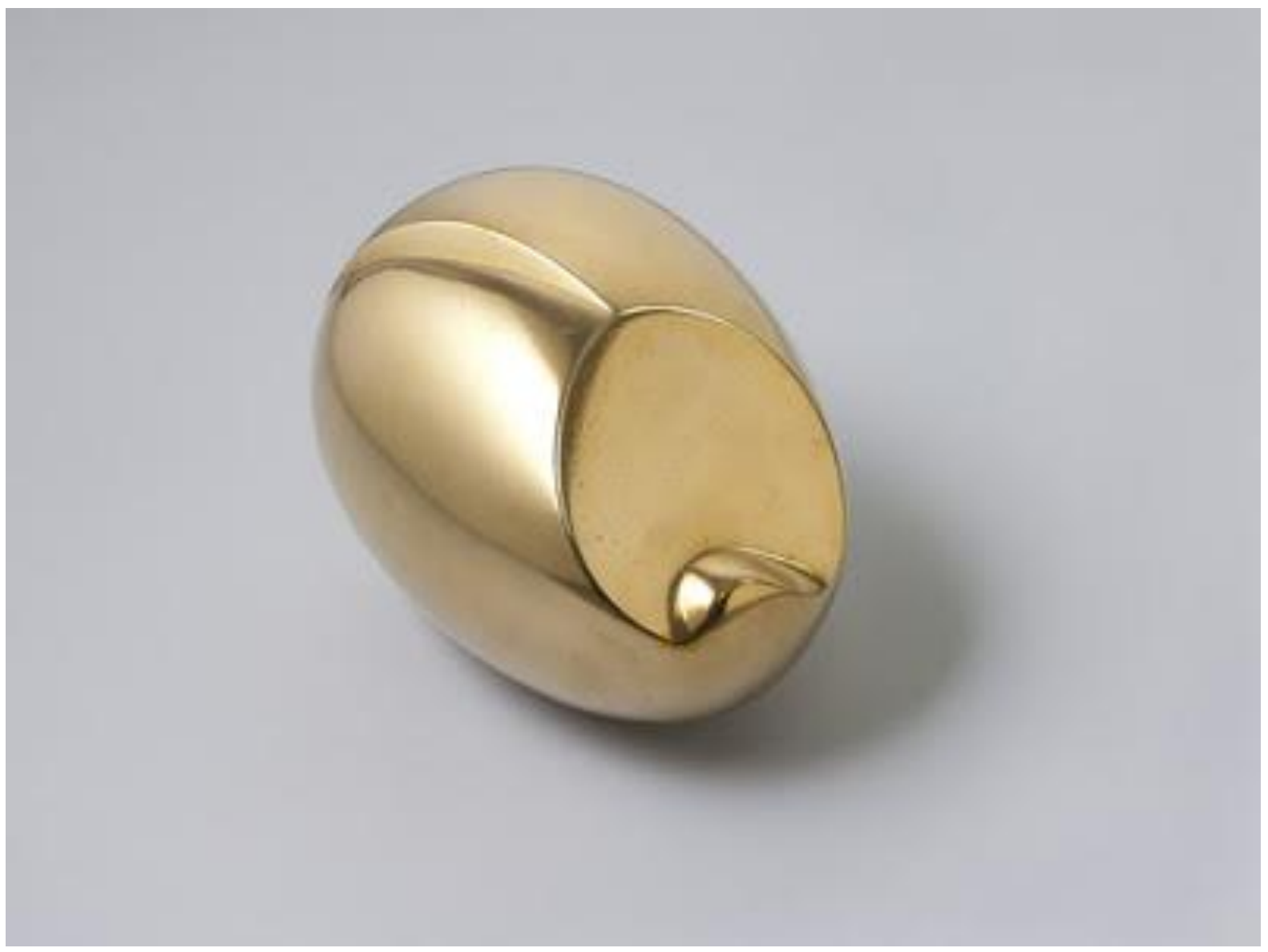

441

${ }^{441}$ Disponível em: http://artemodernaartistas.blogspot.com/2016/01/constantin-brancusi-1876-1957.html 
4. As "colunas com capitéis confusos" 442

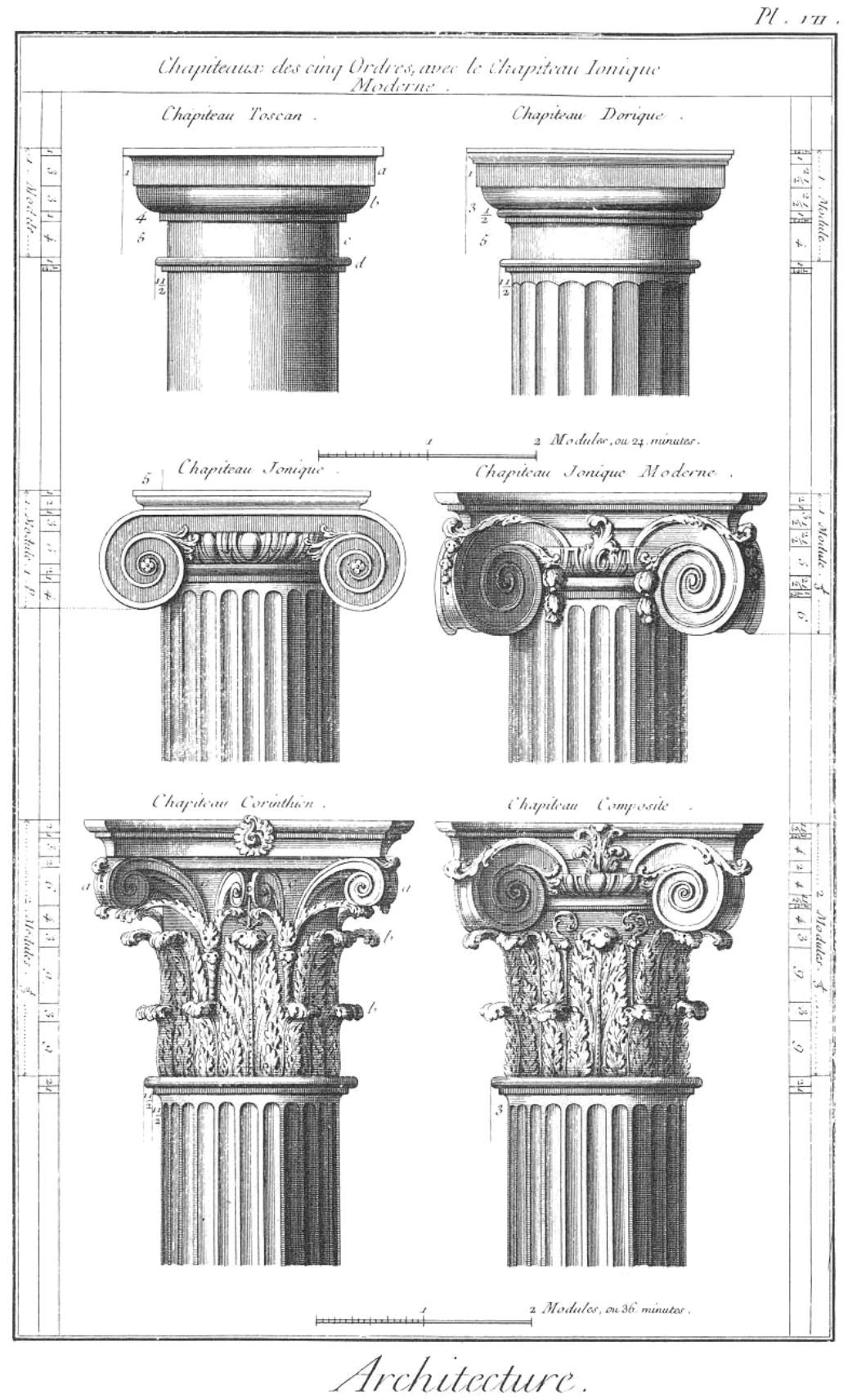

443

442 RILKE, 1995, p. 34.

${ }^{443}$ Disponível em: https://pt.wikipedia.org/wiki/Capitel 
5. Olga de Sá e o "desenho" da narrativa de G.H.

A REVERSÃO PARÓDICA DA CONSCIÊNCIA.

Gráfico da Estrutura Circular dos Capítulos de A paixão segundo G. $H$.

\begin{tabular}{|c|c|c|c|}
\hline I & Início & $\begin{array}{r}\text { XVIII } \\
\text { XIX }\end{array}$ & $\begin{array}{l}\text { Fim } \\
\text { Início }\end{array}$ \\
\hline I & $\begin{array}{l}\text { Fim } \\
\text { Início }\end{array}$ & $\begin{array}{r}\text { XIX } \\
\text { XX }\end{array}$ & $\begin{array}{l}\text { Fim } \\
\text { Início }\end{array}$ \\
\hline III & $\begin{array}{l}\text { Fim } \\
\text { Início }\end{array}$ & $\begin{array}{r}X X \\
X X I\end{array}$ & $\begin{array}{l}\text { Fim } \\
\text { Início }\end{array}$ \\
\hline $\begin{array}{l}\text { III } \\
\text { IV }\end{array}$ & $\begin{array}{l}\text { Fim } \\
\text { Início }\end{array}$ & $\begin{array}{r}\text { XXI } \\
\text { XXII }\end{array}$ & $\begin{array}{l}\text { Fim } \\
\text { Início }\end{array}$ \\
\hline $\begin{array}{c}\text { IV } \\
\text { V }\end{array}$ & $\begin{array}{l}\text { Fim } \\
\text { Início }\end{array}$ & $\begin{array}{r}\text { XXII } \\
\text { XXIII }\end{array}$ & $\begin{array}{l}\text { Fim } \\
\text { Início }\end{array}$ \\
\hline $\begin{array}{c}\mathrm{V} \\
\mathrm{VI}\end{array}$ & $\begin{array}{l}\text { Fim } \\
\text { Início }\end{array}$ & $\begin{array}{l}\text { XXIII } \\
\text { XXIV }\end{array}$ & $\begin{array}{l}\text { Fim } \\
\text { Início }\end{array}$ \\
\hline $\begin{array}{l}\text { VI } \\
\text { VII }\end{array}$ & $\begin{array}{l}\text { Fim } \\
\text { Início }\end{array}$ & $\begin{array}{l}\text { XXIV } \\
\text { XXV }\end{array}$ & $\begin{array}{l}\text { Fim } \\
\text { Início }\end{array}$ \\
\hline $\begin{array}{l}\text { VII } \\
\text { VIII }\end{array}$ & $\begin{array}{l}\text { Fim } \\
\text { Início }\end{array}$ & $\begin{array}{r}\text { XXVI } \\
\text { XXVII }\end{array}$ & $\begin{array}{l}\text { Fim } \\
\text { Início }\end{array}$ \\
\hline $\begin{array}{r}\text { VIII } \\
\text { IX }\end{array}$ & $\begin{array}{l}\text { Fim } \\
\text { Início }\end{array}$ & $\begin{array}{r}\text { XXVII } \\
\text { XXVIII }\end{array}$ & $\begin{array}{l}\text { Fim } \\
\text { Início }\end{array}$ \\
\hline $\begin{array}{r}\mathrm{IX} \\
\mathrm{X}\end{array}$ & $\begin{array}{l}\text { Fim } \\
\text { Início }\end{array}$ & $\begin{array}{r}\text { XXVIII } \\
\text { XXIX }\end{array}$ & $\begin{array}{l}\text { Fim } \\
\text { Início }\end{array}$ \\
\hline $\begin{array}{c}\mathrm{X} \\
\mathrm{XI}\end{array}$ & $\begin{array}{l}\text { Fim } \\
\text { Início }\end{array}$ & $\begin{array}{r}\text { XXIX } \\
\text { XXX }\end{array}$ & $\begin{array}{l}\text { Fim } \\
\text { Início }\end{array}$ \\
\hline $\begin{array}{r}\text { XI } \\
\text { XII }\end{array}$ & $\begin{array}{l}\text { Fim } \\
\text { Início }\end{array}$ & $\begin{array}{r}\text { XXX } \\
\text { XXXI }\end{array}$ & $\begin{array}{l}\text { Fim } \\
\text { Início }\end{array}$ \\
\hline $\begin{array}{r}\text { XII } \\
\text { XIII }\end{array}$ & $\begin{array}{l}\text { Fim } \\
\text { Início }\end{array}$ & $\begin{array}{r}\text { XXXI } \\
\text { XXXII }\end{array}$ & $\begin{array}{l}\text { Fim } \\
\text { Início }\end{array}$ \\
\hline $\begin{array}{l}\text { XIII } \\
\text { XIV }\end{array}$ & $\begin{array}{l}\text { Fim } \\
\text { Início }\end{array}$ & $\begin{array}{l}\text { XXXIII } \\
\text { XXXIV }\end{array}$ & $\begin{array}{l}\text { Fim } \\
\text { Início }\end{array}$ \\
\hline $\begin{array}{c}\text { XIV } \\
\text { XV }\end{array}$ & $\begin{array}{l}\text { Fim } \\
\text { Início }\end{array}$ & $\begin{array}{r}\text { XXXIV } \\
\text { XXXV }\end{array}$ & $\begin{array}{l}\text { Fim } \\
\text { Início }\end{array}$ \\
\hline $\begin{array}{r}\text { XV } \\
\text { XVI }\end{array}$ & $\begin{array}{l}\text { Fim } \\
\text { Início }\end{array}$ & $\begin{array}{r}\text { XXXV } \\
\text { XXXVI }\end{array}$ & $\begin{array}{l}\text { Fim } \\
\text { Início }\end{array}$ \\
\hline $\begin{array}{r}\text { XVI } \\
\text { XVII }\end{array}$ & $\begin{array}{l}\text { Fim } \\
\text { Início }\end{array}$ & & \\
\hline $\begin{array}{l}\text { XVII } \\
\text { XVIII }\end{array}$ & $\begin{array}{l}\text { Fim } \\
\text { Início }\end{array}$ & & \\
\hline
\end{tabular}




\section{REFERÊNCIAS BIBLIOGRÁFICAS}

\section{De Clarice Lispector}

LISPECTOR, Clarice. A cidade sitiada. Rio de Janeiro: Rocco, 1998. . A descoberta do mundo. Rio de Janeiro: Rocco, 1999. . Água viva. Rio de Janeiro: Rocco, 1998. . A hora da estrela. Rio de Janeiro: Rocco, 1998. . A maçã no escuro. Rio de Janeiro: Rocco, 1999. . A paixão segundo G.H.: edição crítica. Org. Benedito Nunes. Madrid; Paris; México; Buenos Aires; São Paulo; Rio de Janeiro; Lima: ALLCA XX, 1996. . A paixão segundo G.H.. Rio de Janeiro: Rocco, 2009. . Clarice na cabeceira: jornalismo. Org. Aparecida Maria Nunes. Rio de Janeiro: Rocco, 2012.

. Correio para mulheres. Rio de Janeiro: Rocco, 2018.

. Entrevistas. Org. Claire Williams e Teresa Montero. Rio de Janeiro:

Rocco, 2007. . O lustre. Rio de Janeiro: Rocco, 1999.

. Outros escritos. Org. Teresa Montero e Lícia Manzo. Rio de Janeiro:

Rocco, 2005.

. Panorama com Clarice Lispector. Entrevista concedida a Júlio

Lerner. São Paulo: TV Cultura, 1977. Disponível em:

$<$ https://www.youtube.com/watch? $=0$ ohHP112EVnU $>$.

. Perto do coração selvagem. Rio de Janeiro: Rocco, 1998.

. Todas as crônicas. Org. Pedro Karp Vasquez. Rio de Janeiro: Rocco, 2018.

. Todos os contos. Org. Benjamin Moser. Rio de Janeiro: Rocco, 2016. . Uma aprendizagem ou O livro dos prazeres. Rio de Janeiro: Rocco, 1998. . Um sopro de vida. Rio de Janeiro: Rocco, 1999. 


\section{Sobre Clarice Lispector}

ALONSO, Mariângela. A água e as pulsões em O lustre, de Clarice Lispector. Curitiba: Appris, 2019.

. "Deformações da interioridade: marcas expressionistas em O lustre, de Clarice Lispector". Opiniães, São Paulo, n. 15, p. 213-235, 2019.

. "Dimensões especulares em A paixão segundo G.H., de Clarice Lispector". Revista do Sell, v. 4, n. 2, p. 1-19, 2014.

. Instantes líricos de revelação: a narrativa poética em A paixão segundo G.H.. 2007. 108 f. Dissertação (Mestrado em Estudos Literários). Faculdade de Ciências e Letras, Universidade Estadual de São Paulo, Araraquara.

; LEITE, Guacira Marcondes Machado. "O substrato mítico em $A$

paixão segundo G.H., de Clarice Lispector". Revista de Letras, Universidade Federal do Ceará, v.1, n. 29, p. 11-16, 2007.

"Um enredamento de baratas: a mise en abyme em 'A quinta história', de Clarice Lispector". Estação Literária, Londrina, v. 7, p. 57-67, 2011.

AMARAL, Emília. O leitor segundo G.H.. São Paulo: Ateliê Editorial, 2005.

ARÊAS, Vilma. Clarice Lispector com a ponta dos dedos. São Paulo: Companhia das Letras, 2005.

BORELLI, Olga. Clarice Lispector: esboço para um possivel retrato. São Paulo: Editora Nova Fronteira, 1981.

CANDIDO, Antonio. "No raiar de Clarice Lispector". In: Vários Escritos. São Paulo: Duas Cidades, 1970, p. 125-131.

CHEREM, Lúcia Peixoto. As duas Clarices - entre a Europa e a América: leitura e tradução de Clarice Lispector na França e no Quebec. Curitiba, Paraná: Editora UFPR, 2013.

CHIAPPINI, Ligia. "Pelas ruas da cidade uma mulher precisa andar: leitura de Clarice Lispector". Literatura e sociedade, v. 1, n.1, p. 60-80, 1996.

GOTLIB, Nádia Batella. Clarice: uma vida que se conta. São Paulo: EDUSP, 2013.

HACK, Lilian. "Clarice Lispector e as entrevistas com artistas: uma escuta da pintura". Revista Valise, Porto Alegre, v. 7, n. 14, ano 7, p. 70-89, dez./2017.

HEGENBERG, Ivan. Clarice Lispector e as fronteiras da linguagem: uma leitura interdisciplinar do romance Água viva. São Paulo: Benjamin Editorial, 2018.

IANNACE, Ricardo. A leitora Clarice Lispector. São Paulo: Editora da Universidade de São Paulo, 2001. 
Retratos em Clarice Lispector: literatura, pintura e fotografia. Belo Horizonte, Minas Gerais: Editora UFMG, 2009.

KAHN, Daniela. A via crucis do outro: identidade e alteridade em Clarice Lispector. São Paulo: Associação Editorial Humanitas: FAPESP, 2005.

LEAL, Amaury Jorge Lins. "Clarice Lispector, Jackson Pollock e a técnica de composição do expressionismo abstrato". Cerrados, Brasília, n. 7, p. 53-61, 1998.

MARTINS, Gilberto Figueiredo. As vigas de um heroísmo vago: três estudos sobre A maçã no escuro. 1996. Dissertação (Mestrado em Literatura Brasileira). Faculdade de Filosofia, Letras e Ciência Humanas, Universidade de São Paulo, São Paulo.

- Estátuas invisíveis: experiências do espaço público na ficção de Clarice Lispector. São Paulo: Nankin: EDUSP, 2010.

MOSER, Benjamin. Clarice, uma biografia. São Paulo: Cosac Naify, 2013.

NODARI, Alexandre André. "'A vida oblíqua': o hetairismo ontológico segundo G.H.". O Eixo e a roda, Belo Horizonte, v. 24, n.1, p. 139-154, 2015.

NUNES, Benedito. O drama da linguagem: uma leitura de Clarice Lispector. São Paulo: Ática, 1995. . "O mundo imaginário de Clarice Lispector". In: O dorso do tigre. São Paulo: Editora 34, 2009, p. 93-134.

PENNA, João Camillo. "O nu de Clarice Lispector". ALEA - Estudos Neolatinos. UFRJ, Rio de Janeiro, v. 12, n. 1, p. 68-96 jan./jun. 2010.

PINTO, Cristina Ferreira. O Bildungsroman feminino: quatro exemplos brasileiros. São Paulo: Perspectiva, 1990.

PONTIERI, Regina. Clarice Lispector: uma poética do olhar. São Paulo: Ateliê Editorial, 2001.

ROSENBAUM, Yudith. Metamorfoses do mal: uma leitura de Clarice Lispector. São Paulo: Editora da Universidade de São Paulo: FAPESP, 2006.

RUFINONI, Simone. "'O artista perfeito': Clarice Lispector e a poética da inocência". Remate de Males. Campinas - SP: v. 36, n.2, p. 357-379, jul./dez. 2016.

SANTOS, Rejane Granato; ROCHA, Enilce Albergaria. "A escrita pictórica em A cidade sitiada, de Clarice Lispector". Ipotesi, Juiz de Fora, v. 9, n. 1, n. 2, p. 155-166, jan/jun, jul/dez 2005.

SÁ, Olga de. A escritura de Clarice Lispector. Petrópolis: Vozes; PUC-SP, 1993. . Clarice Lispector: A travessia do oposto. São Paulo: Annablume, 2004. 
SILVA, Flávia Lins e. "'O figurativo do inominável': aspectos da criação textual em Água viva, de Clarice Lispector". Em tese, Belo Horizonte, v. 8, p. 101-110, dez. 2004.

SOUSA, Carlos Mendes de. Clarice Lispector: Figuras da escrita. Minho, Portugal: Universidade do Minho, 2001.

Clarice Lispector: Pinturas. Rio de Janeiro: Rocco, 2013.

SOUZA, Gilda de Mello e. "O vertiginoso relance". In: Exercícios de leitura. São Paulo: Duas Cidades, 1980, p. 79-91.

SCHWARZ, Roberto. "Perto do coração selvagem". In: A sereia e o desconfiado: ensaios críticos. Rio de Janeiro: Editora Civilização Brasileira, 1965, p. 37-41.

STIGGER, Veronica. O útero do mundo. São Paulo: Museu de Arte Moderna de São Paulo, 2016. Catálogo de exposição, 05 set.-18 dez. 2016, MAM.

OLIVEIRA, Solange Ribeiro de. A barata e a crisálida: o romance de Clarice Lispector. Rio de Janeiro: José Olympio, 1985.

. Literatura e artes plásticas: O Künstlerroman na ficção contemporânea. Ouro Preto, Minas Gerais: Editora na UFOP, 1993. - "Literatura e pintura abstrata: Água viva de Clarice Lispector". Aletria, Belo Horizonte, v. 27, n. 2, p. 261-276, 2017. - "Rumo à Eva do futuro: A mulher no romance de Clarice Lispector”. Remate de males. Campinas - SP: v. 9, p. 95-105, 1989.

WALDMAN, Berta. Clarice Lispector: A paixão segundo C.L.. São Paulo: Editora Escuta, 1992.

\section{Geral}

ADORNO, Theodor. "Posição do narrador no romance contemporâneo". In: Notas de literatura I. São Paulo: Duas Cidades; Editora 34, 2012, p. 55-63.

ANDRADE, Mário de. Aspectos das artes plásticas no Brasil. São Paulo: Livraria Martins Editora, 1965.

AUERBACH, Erich. "A meia marrom". In: Mimesis: A representação da realidade na literatura ocidental. São Paulo: Perspectiva, 2013, p. 471- 498.

BAKHTIN, Mikhail. "O romance de educação e sua importância na história do realismo". In: Estética da criação verbal. São Paulo: Editora WMF Martins Fontes, 2011, p. 205-258. BANDEIRA, Manuel. "O escultor". In: Poesia completa e prosa. Volume único. Org. André Seffrin. Rio de Janeiro: Editora Nova Aguilar, 2009, p. 832. 
BOOTH, Wayne. The rethoric of fiction. Chicago: The University of Chicago Press, 1983.

BOSI, Alfredo. Reflexões sobre a arte. São Paulo: Editora Ática, 1986.

BÜRGER, Peter. Teoria da vanguarda. Lisboa: Vega, 1993.

CALVINO, Italo. Por que ler os clássicos. São Paulo: Companhia de bolso. E-book.

CANDIDO, Antonio. "O direito à literatura". In: Vários escritos. Rio de Janeiro: Ouro sobre azul, 2011, p. 171-193.

FLETCHER, John; BRADBURY, Malcolm. "O romance de introversão". In: BRADBURY, Malcolm; MCFARLANE, James (Org). Modernismo: guia geral 1890-1930. São Paulo: Companhia das Letras, 1989, p. 322-339.

FRANK, Joseph. "A forma espacial na literatura moderna". Revista USP, São Paulo, n. 58, p. 225-241, jun./ago. 2003.

FRIAS, Joana Matos. "Écfrase: 10 aporias". Elyra - Revista da Rede Internacional Lyracompoetics, Porto, v. 8, n. 12, p. 33-40, 2016.

GOMES, Álvaro Cardoso. A poesia como pintura: A ekphrasis em Albano Martins. Cotia, SP: Ateliê Editorial, 2015.

HANSEN, João Adolfo. "Categorias epidíticas da ekphrasis". Revista USP, São Paulo, n. 71, p. 85-105, set/nov 2006.

HEFFERNAN, James A. W. "Ekphrasis and Representation". New Literary History, vol. 22, n. 2, p. 297-316, 1991.

HORÁCIO. Arte poética. Lisboa: Editorial Inquérito Lisboa.

KANGUSSU, Imaculada. "Sobre a alteridade do artista em relação ao mundo que o cerca, segundo Herbert Marcuse". Revista Kriterion, Belo Horizonte, n. 112, p. 345-356, dez./2005. KRAUSS, Rosalind. "A escultura no campo ampliado". Arte \& ensaios, Rio de Janeiro, n. 17, p. 128-137, 2008.

. Passages in Modern Sculpture. Nova Iorque: The Viking Press, 1977.

LESSING, G. E. Laocoonte ou sobre as fronteiras da pintura e da poesia. São Paulo: Editora Iluminuras, 2011.

LUKÁCS, Georg. A teoria do romance: um ensaio histórico-filosófico sobre as formas da grande épica. São Paulo: Duas Cidades; Editora 34, 2009. . "O romance como epopeia burguesa". In: Ad Hominem 1 - Revista de Filosofia, política, ciência da história. Tomo II: Música e literatura. Inujuí, RS: Editora Unijuí, p. 87-117, 1999. 
MARCUSE, Herbert. "The German Artist Novel: Introduction". In: KELLNER, Douglas (Org). Art and liberation: Collected papers of Herbert Marcuse, vol. 4. Nova Iorque: Routledge, 2007, p. 71-81.

MARTINS, Paulo. "Uma visão periegemática sobre a écfrase". Revista Clássica, v. 29, n. 2, p. 163-204, 2016.

MIDGLEY, Barry (Org.). Guia completa de escultura, modelado y ceramica: tecnicas y materiales. Madrid: Hermann Blume Ediciones, 1981.

QUINTAIS, Luís. "A ekphrasis como meta-representação". Relâmpago - Revista de poesia. Lisboa: Fundação Luís Miguel Nava, n. 23, p. 94-96, out./2008.

REITZ, Charles. Art, alienation and the humanities: a critical engagement with Herbert Marcuse. Nova Iorque: State University of New York Press, 2000.

RILKE, Rainer Maria. Rodin. Rio de Janeiro: Relume-Dumará, 1995.

RODIN, Auguste. Faire avec ses mains ce que l'on voit. Paris: Mille et une nuits, département de la Librairie Arthème Fayard, 2011.

ROSENFELD, Anatol. "À procura do mito perdido: notas sobre a crise do romance psicológico". In: Letras e leituras. São Paulo: Perspectiva, p. 21-32.

. "Reflexões sobre o romance moderno". In: Texto/Contexto I. São

Paulo: Perspectiva, 1996, p. 75-97.

SILVA, João Castro. "Maria Lino: a escultura como modo de vida". Revista Estúdio, Lisboa, v. 9, n. 23, p. 121-132, set./2018.

TODOROV, Tzvetan. "Os homens-narrativas". As estruturas narrativas. São Paulo: Perspectiva, 2006, p. 119-133.

TUCKER, William. The language of sculpture. Londres: Thames and Hudson, 1994.

VIEIRA, Miriam de Paiva. "Écfrase: de recurso retórico na antiguidade a fenômeno midiático na contemporaneidade". Todas as Letras. São Paulo, v. 19, n. 1, p. 45-57, jan./abr. 2017.

WILSON, Colin. The Outsider. Nova Iorque: Diversion Books, 2014. E-book

WISNIK, Guilherme. Dentro do nevoeiro: diálogos cruzados entre arte e arquitetura contemporânea. 2012. 262 f. Tese (Doutorado em Arquitetura e do Urbanismo) - Faculdade de Arquitetura e Urbanismo, Universidade de São Paulo, 2012.

WOOLF, Virginia. A arte do romance. São Paulo: L\&PM Pocket, 2018. . O valor do riso e outros ensaios. São Paulo: Cosac Naify, 2014. Profissões para mulheres e outros artigos feministas. São Paulo: L\&PM

Pocket, 2018. . Selected essays. Oxford: Oxford University Press, 2009. . Um teto todo seu. São Paulo: Tordesilhas, 2014. E-book. 